\title{
54. MESOZOIC-TERTIARY TECTONIC EVOLUTION OF THE EASTERNMOST MEDITERRANEAN AREA: INTEGRATION OF MARINE AND LAND EVIDENCE ${ }^{1}$
}

\author{
Alastair H.F. Robertson ${ }^{2}$
}

\begin{abstract}
This paper presents a synthesis of Holocene to Late Paleozoic marine and land evidence from the easternmost Mediterranean area, in the light of recent ODP Leg 160 drilling results from the Eratosthenes Seamount. The synthesis is founded on three key conclusions derived from marine- and land-based study over the last decade. First, the North African and Levant coastal and offshore areas represent a Mesozoic rifted continental margin of Triassic age, with the Levantine Basin being underlain by oceanic crust. Second, Mesozoic ophiolites and related continental margin units in southern Turkey and Cyprus represent tectonically emplaced remnants of a southerly Neotethyan oceanic basin and are not far-travelled units derived from a single Neotethys far to the north. Third, the present boundary of the African and Eurasian plates runs approximately east-west across the easternmost Mediterranean and is located between Cyprus and the Eratosthenes Seamount. The marine and land geology of the easternmost Mediterranean is discussed utilizing four north-south segments, followed by presentation of a plate tectonic reconstruction for the Late Permian to Holocene time.
\end{abstract}

\section{INTRODUCTION}

The objective here is to integrate marine- and land-based geological and geophysical information related to the tectonic evolution of the easternmost Mediterranean from Holocene to Late Paleozoic time (Fig. 1), in the light of the results of drilling the Eratosthenes Seamount south of Cyprus during Leg 160. The main aim of the drilling was to test the hypothesis that the Pliocene-Pleistocene uplift of southern Cyprus is related to collision of the Eratosthenes Seamount, a substantial bathymetric feature, with southern Cyprus. This collision took place along the Cyprus active margin, a segment of the boundary of the African and Eurasian plates. The drilling of a northsouth traverse of three holes across the seamount, together with another hole at the base of the Cyprus slope, has demonstrated that the Eratosthenes Seamount is a foundered carbonate platform, in the process of faulting and thrusting beneath southern Cyprus. In addition, Leg 160 has focused attention on the history of the Cyprus active margin in its regional tectonic context.

In the past, many geologists believed that the Eastern Mediterranean Sea should simply be regarded as a northward extension of the African continental margin (e.g., Hirsch et al., 1984; Hirsch et al., 1995). If so, the Mesozoic ophiolites and related allochthonous units in the Eastern Mediterranean, such as the Troodos ophiolite in Cyprus, were thrust vast distances (hundreds of kilometers) southward over this continental margin from a single Mesozoic (Neotethyan) ocean far to the north, in the vicinity of northern Turkey (Ricou et al., 1984; Marcoux et al., 1989). If this were correct, any detailed palinspastic (i.e., paleogeographic and tectonic) reconstruction of the easternmost Mediterranean would be virtually impossible, since there would be little relationship between the emplaced Mesozoic allochthonous units and the paleotectonic development of the present Mediterranean Sea.

However, it is now clear that the easternmost Mediterranean Sea and surrounding land areas are remnants of a southerly Neotethyan (mainly Mesozoic) ocean basin that formed part of a larger Tethyan

${ }^{1}$ Robertson, A.H.F., Emeis, K.-C., Richter, C., and Camerlenghi, A. (Eds.), 1998. Proc. ODP, Sci. Results, 160: College Station, TX (Ocean Drilling Program).

${ }^{2}$ Department of Geology and Geophysics, University of Edinburgh, Edinburgh, EH9 3JW, United Kingdom. Alastair.Robertson@glg.ed.ac.uk ocean (Figs. 2, 3; Le Pichon, 1982). The easternmost Mediterranean is defined as that part of the Eastern Mediterranean Sea located east of the Aegean (east of $28^{\circ} \mathrm{E}$ longitude). At present, no one paleogeography is agreed upon by various workers (Figs. 2A-D, 3A-D). It is generally agreed that from Late Cretaceous to Holocene, the Eastern Mediterranean has been in a state of diachronous collision, although the location of root zones and distance of thrusting of allochthonous units remains controversial (Fig. 3C, D). In general, areas to the east of the Levant are now in a postcollisional phase (Dewey et al., 1986; Pearce et al., 1990), whereas areas to the west are still in an earlycollisional phase (Robertson and Grasso, 1995).

The conclusion that the Eastern Mediterranean originated as a small Neotethyan oceanic basin rests on three main lines of evidence. First, the present-day plate boundary of the African and Eurasian plates runs through the Eastern Mediterranean. This was long inferred (McKenzie, 1978; Dewey and Şengör, 1979), but only recently confirmed mainly by seismic evidence (Kempler and Ben-Avraham, 1987; Anastasakis and Kelling, 1991). The location of the plate boundary south of Cyprus is now clarified by the Leg 160 drilling results (Emeis, Robertson, Richter, et al., 1996; Robertson et al., 1995b) and related studies of southern Cyprus (Robertson et al., 1991b). Second, seismic refraction studies, combined with regional gravity and magnetic anomaly patterns (Woodside, 1977), strongly suggest that the Eastern Mediterranean seafloor between North Africa and the Levant onshore is composed of Mesozoic oceanic crust (Makris et al., 1983; Ben-Avraham, 1986; Ben-Avraham and Tibor, 1994). The present-day Levant coast corresponds to a Mesozoic passive continental margin that passes oceanward into oceanic crust within the easternmost Mediterranean area (Bien and Gvirtzman, 1977; Garfunkel and Derin, 1984). A continuum of geological processes exists within the easternmost Mediterranean area, beginning with rifting and continental breakup in the Permian-Triassic, followed by passive margin subsidence and then incipient continental collision of the African and Eurasian plates along the Cyprus active margin. Third, detailed field-based sedimentary and structural studies of northern Cyprus (Robertson and Woodcock, 1979) and southwestern Turkey (Woodcock and Robertson, 1982; Hayward and Robertson, 1982; Robertson, 1993) demonstrate that Mesozoic ophiolites and related allochthonous units in these areas are emplaced remnants of a southerly Neotethyan ocean basin. The Neotethys in the Mediterranean region was paleogeographically varied and can be com-

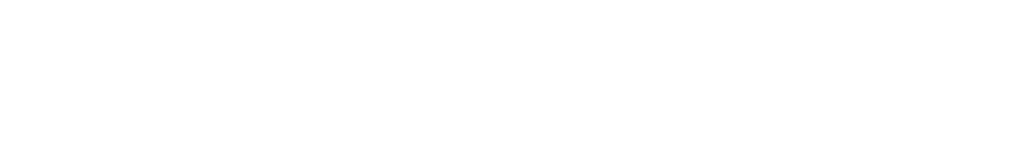




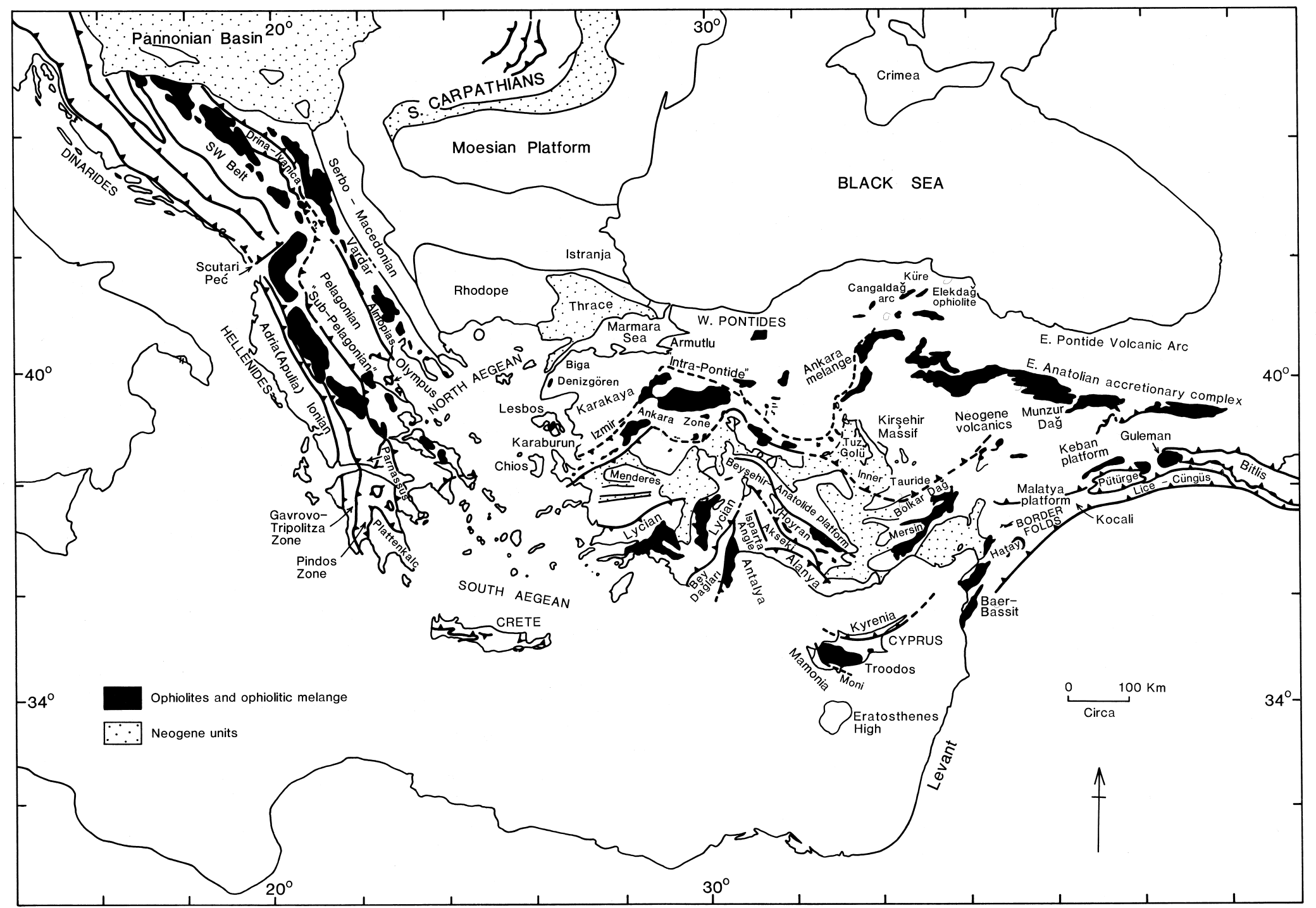

Figure 1. Outline tectonic map of the easternmost Mediterranean showing the main tectonic features discussed in this paper. The discussion focuses in the area east of latitude $24^{\circ} \mathrm{E}$ and south of $40^{\circ} \mathrm{N}$. More details of submarine features are shown in Figures 6 and 7. The map highlights Mesozoic tectonic lineaments only. 

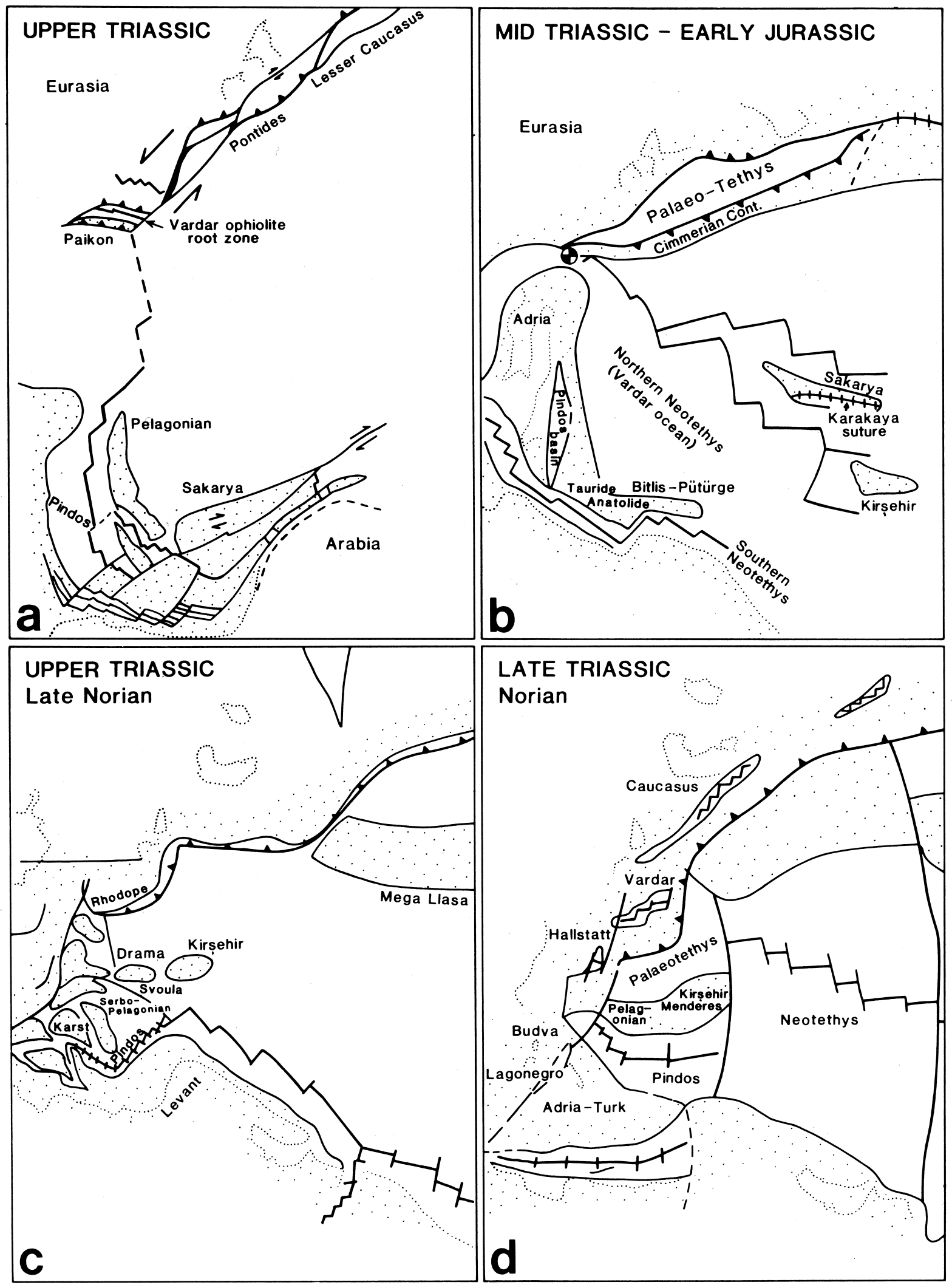

Figure 2. Alternate reconstructions of the Eastern Mediterranean Neotethys for Late Triassic time. A. As a small ocean basin of Red Sea type (favored option; Robertson and Dixon, 1984; Robertson et al., 1991a). B. As a back-arc basin above a southward-dipping subduction zone (Şengör and Yilmaz, 1981; Şengör, 1984; Şengör et al., 1984). C. As a single Pindos oceanic basin (Dercourt et al., 1993). D. As a by-then, somewhat well-established oceanic basin dating from the Permian (Stampfli, in Dercourt et al., 1992). In the present account a modified version of (A) is favored, with a wider southerly Neotethys in the easternmost Mediterranean area. 

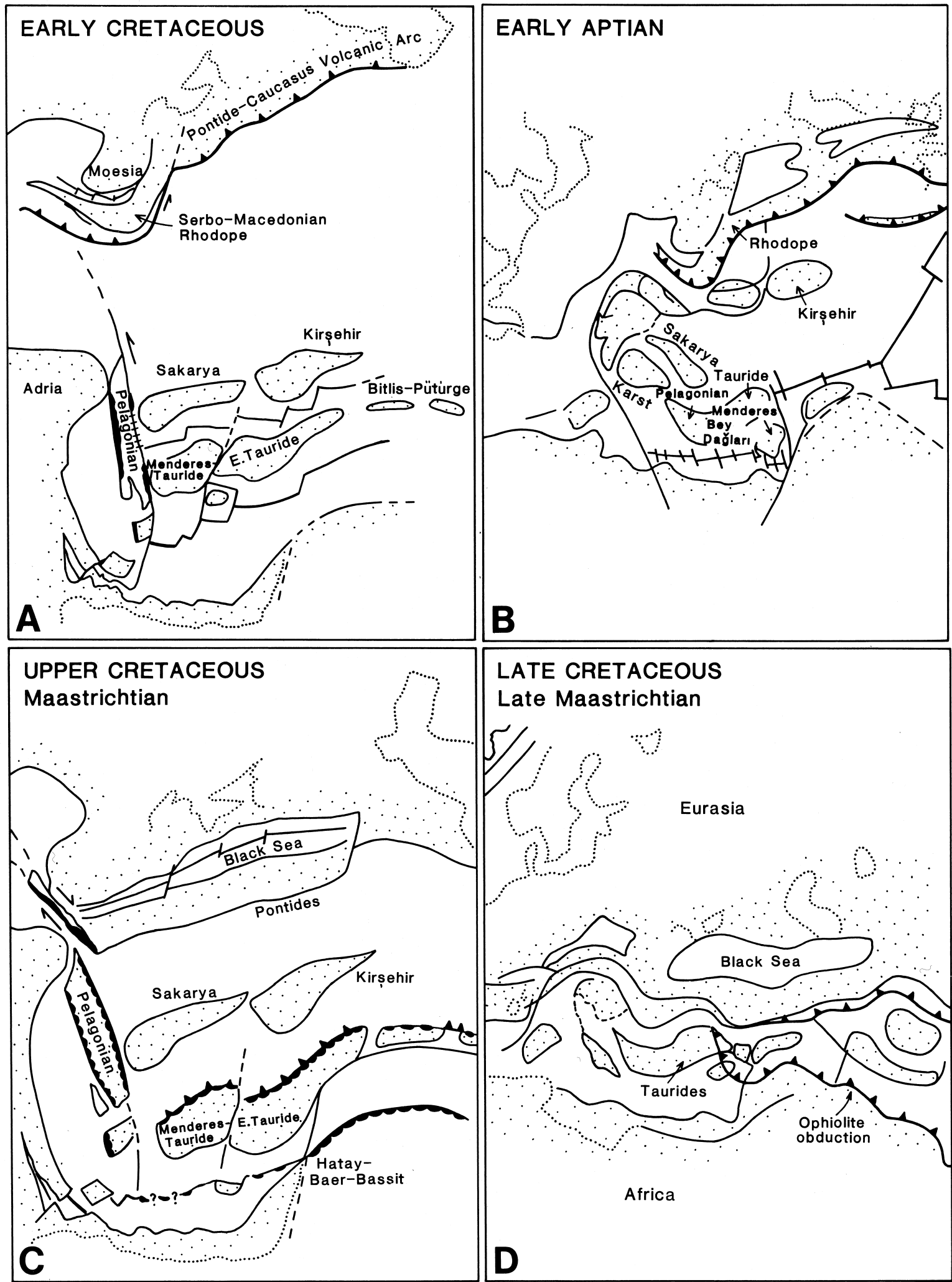

\section{LATE CRETACEOUS \\ Late Maastrichtian}
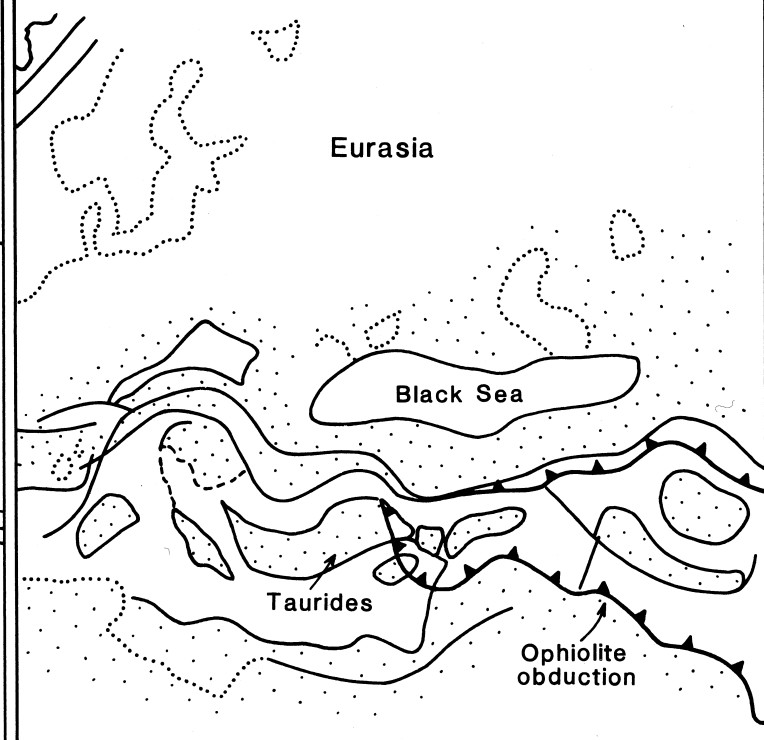

Africa

D

Figure 3. Alternate reconstructions of the Eastern Mediterranean Neotethys for Early to Mid-Cretaceous time. A. Maximum width of the Neotethys with several microcontinents (Robertson and Dixon, 1984). B. With a new rifted Cretaceous oceanic basin in the easternmost Mediterranean (Dercourt et al., 1992). C. Late Cretaceous ophiolite obduction from several oceanic basins (Robertson and Dixon, 1984). D. Ophiolite obduction from a single northerly basin (Dercourt et al., 1992). 
pared with the Caribbean or the southwestern Pacific regions in complexity.

It will be assumed here, first, that the easternmost Mediterranean is, indeed, a remnant Neotethyan ocean, and, second, that many of the ophiolites and related units, including the Troodos ophiolite in $\mathrm{Cy}-$ prus, are fragments of this southerly Neotethyan ocean basin. This, then, is the starting point for a fresh look at the overall tectonic evolution of the easternmost Mediterranean that integrates evidence from land and sea. The main emphasis here is on the tectonic evolution of the plate boundary and areas further north, including Cyprus, southern and southeastern Turkey and offshore areas, but the main features of the North Africa-Levant passive margin and offshore areas will also be briefly summarized.
Numerous hypotheses for the tectonic evolution of the Eastern Mediterranean region have been published. Many of these are problematic in terms of the information presented in this paper. Space does not permit full discussion of all of these alternatives, but they are indicated in Figure 4, with appropriate references to the literature to allow the reader to follow up alternative interpretations.

This paper is organized as follows: the evolution of the North African-Levant margins is first briefly summarized, then the areas north of the plate boundary are discussed in turn, utilizing four broad northsouth segments (Fig. 5) from west to east.

Today, marked differences in geology and tectonic history exist from the west to the east across the easternmost Mediterranean. In the west, continental collision has hardly begun (Segment 1); further

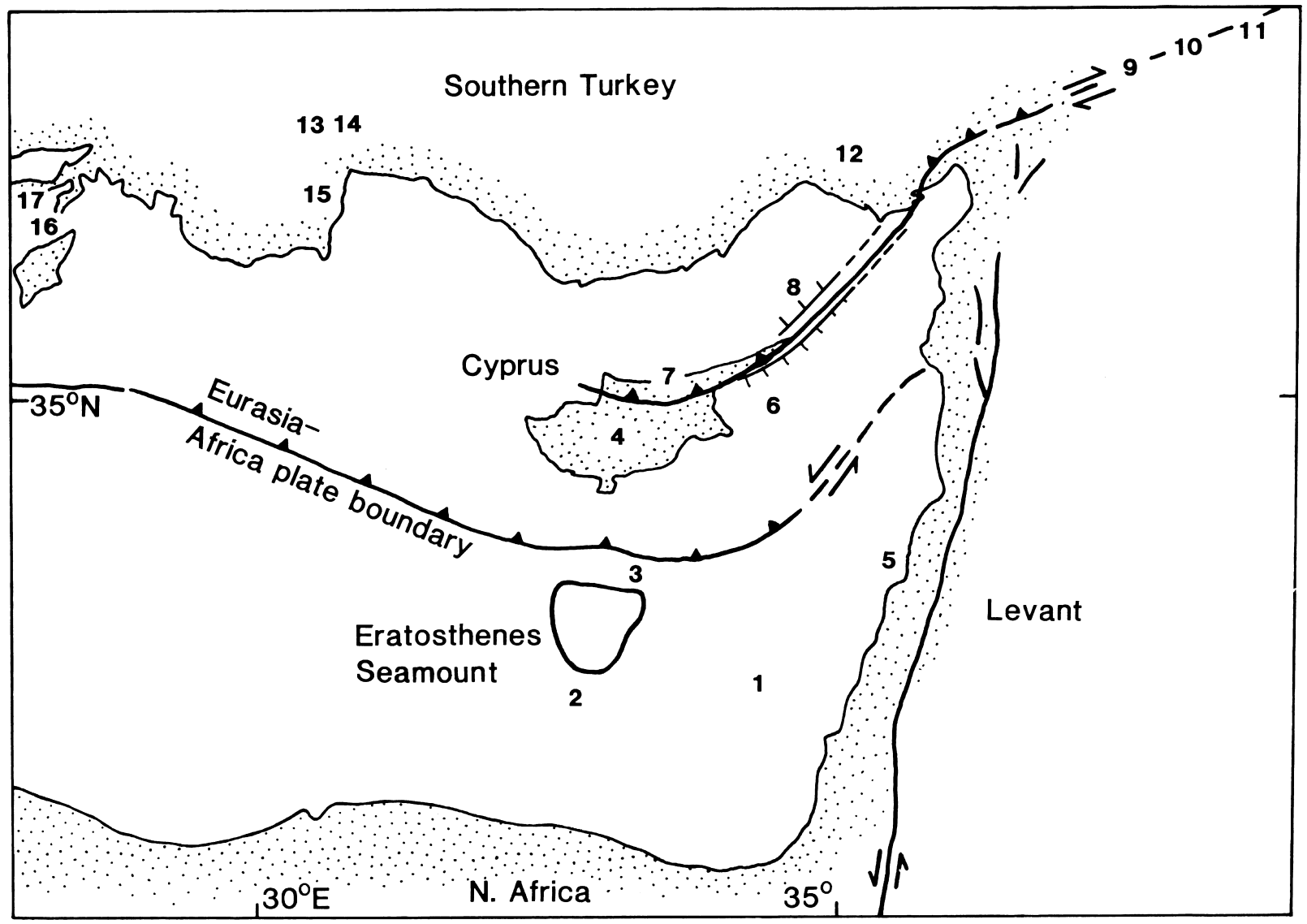

Figure 4. Sketch maps showing areas for which some hypotheses are considered to be problematic by the writer. Reasons are given in the text, but lack of space precludes full discussion of these alternatives in this paper. 1. Levant Sea underlain by continental crust? (Hirsch et al., 1995). 2. Eratosthenes Seamount being subducted southward? (Ben-Avraham and Nur, 1982; Ben-Avraham, 1986). 3. Eratosthenes Seamount as a buried Mesozoic volcanic arc related to southward subduction (Hsü, 1990). 4. Troodos as a grossly allochthonous nappe thrust from the north (Whitechurch et al., 1984), or formed in a marginal basin above southward-dipping subduction zone (Dilek and Moores, 1990). 5. Fold-structures of pre-Santonian age in the deep-water Levant margin predate first evidence of regional compressional tectonics (Mart, 1994). (This might relate to compressional stresses propagated southward during initiation of northward-dipping subduction zones connected with ophiolite genesis.) 6. Strike-slip lineaments to the east of Cyprus pass onshore? (Ben-Avraham et al., 1995). 7. Maastrichtianlower Tertiary volcanics in the Kyrenia Range interpreted as subduction arc related? (Baroz, 1980). 8. The Kyrenia Range viewed as undergoing about $150 \mathrm{~km}$ of left-lateral strike-slip displacement during the mid-Tertiary (Kempler and Garfunkel, 1994). 9. Miocene basins in southern Turkey developed by extensional faulting, rather than as a foredeep, as in traditional interpretation (Karig and Közlü, 1990). 10. Eocene Halete volcanics represent a volcanic arc but without supporting geochemical data (Yilmaz, 1993). 11. Metamorphic units represent upthrust Arabian basement (Yazgan, 1984) rather than Neotethyan margin units. 12. The Miocene Adana basin interpreted as flexural foredeep related to southward thrusting despite lacking evidence of any exposed thrust load (Williams et al., 1995). 13. Antalya "Nappes" are grossly allochthonous and thrust from the north from a single Neotethyan ocean located in central and northern Turkey (Marcoux et al., 1989). 14. The Antalya Complex rifted to form a small ocean basin only in the Cretaceous, rather than the Triassic? (Dilek and Rowland, 1993$) .15$. Extensional faults in Antalya Complex (Glover, 1996) mapped as thrusts (Frizon de Lamotte et al., 1995). 16. Compressional features on the northern margin of Anaximander Seamounts represent a major convergence zone (Ivanov et al., 1991). 17. The deep Rhodes Basin is stranded Mesozoic oceanic crust rather than essentially a Neotectonic feature (see Mascle et al., 1986). 
east, collision is incipient (Segments 2 and 3); eastward again, in southeastern Turkey (Segment 4) collision of the African and Eurasian plates is well advanced, dating from the late Eocene-Miocene.

In this paper the stratigraphy will be summarized beginning with younger units, followed by older units. This approach is adopted because the Pliocene-Pleistocene setting of the Eastern Mediterranean Sea is now quite well documented, whereas the earlier history remains poorly understood, mainly because of the existence of widespread, thick, late Miocene (Messinian) salt that impedes seismic exploration. Deep-sea drilling has helped confirm the Pliocene-Pleistocene history, whereas underlying marine units have barely been sampled. On land, on the other hand, much study has focused on the Mesozoic "alpine" units, or ophiolites, and, until recently, little attention was paid to Neogene-Pleistocene units. A stratigraphic "topdown" approach thus aids integration of marine and land evidence. In the final section of the paper, however, all the available information is synthesized into a unified tectonic model, working upward through time.

The main offshore tectonic features are shown in Figures 6 and 7, based on compilations of bathymetric gravity, magnetic, and seismic data (Hall, 1994; Bogdanov et al., 1994; Ginsman et al., 1993; Rybakov et al., 1994).

\section{SOUTH MARGIN OF NEOTETHYS: THE NORTH AFRICA-LEVANT PASSIVE MARGIN}

Boreholes and seismic profiles through the Israel coastal plain and offshore reveal a pattern of overall subsidence to the west in TriassicEarly Jurassic time. Early Jurassic volcanics were recovered from deep wells beneath the Israel coastal plain (e.g., Atlit-1 well; Bien and Gvirtzman, 1977; Gvirtzman and Steinitz, 1982; Freund et al., 1975; Hirsch et al., 1984). This is interpreted as evidence of a Triassic rift, passing westward into early Mesozoic ocean crust (Garfunkel and Derin, 1984). This passive margin has persisted throughout the Mesozoic to Holocene time (Mart, 1984, 1987; Gvirtzman, 1990, 1993; Gvirtzman et al., 1989). Some authors see the Lower Jurassic volcanics as evidence of only intra-plate rifting, without any spreading to form oceanic crust at any time in the easternmost Mediterranean area (Hirsch et al., 1995). For others, rifting occurred in the Triassic, but ocean-crust spreading in the easternmost Mediterranean was delayed until the Cretaceous (Dercourt et al., 1986; Z. Ben-Avraham, pers. comm., 1996; J. Makris, pers. comm., 1996). On the other hand, Stampfli et al. (1991) argue that ocean floor spreading in the easternmost Mediterranean began as early as the Late Permian, mainly based on the subsidence history of the neighboring passive margin. Also, K.J. Hsü (pers. comm., 1993) suggested a Permian age for the easternmost Mediterranean Sea in view of the apparent absence of magnetic anomalies.

Two aspects have remained problematic until recently: first, is the crust beneath Levantine Basin merely thinned continental crust, or true oceanic crust? Second, are Cyprus and the Eratosthenes Seamount part of a single crustal unit, or different units separated by a plate boundary? Woodside (1977) favored an origin of the Eratosthenes Seamount as an upthrust extension of thinned North African continental crust, but, alternatively, this unit could be a continental fragment surrounded by oceanic crust.

The available evidence supports an origin of the easternmost Mediterranean as a small ocean basin created in the Middle-Late Triassic with rifting dating back at least to the Late Permian. Some of

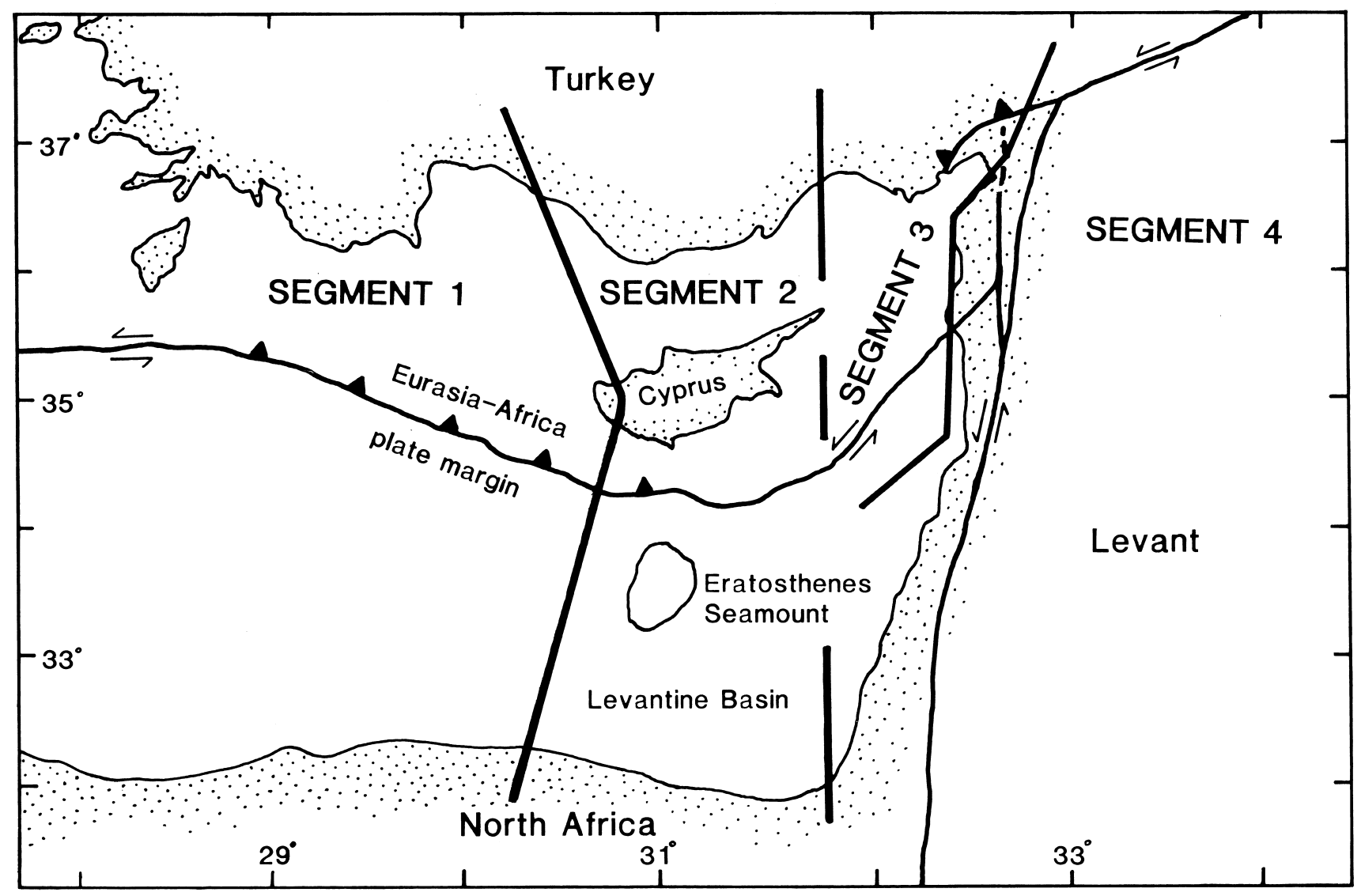

Figure 5. Sketch map showing the four main segments that are discussed in this paper. 


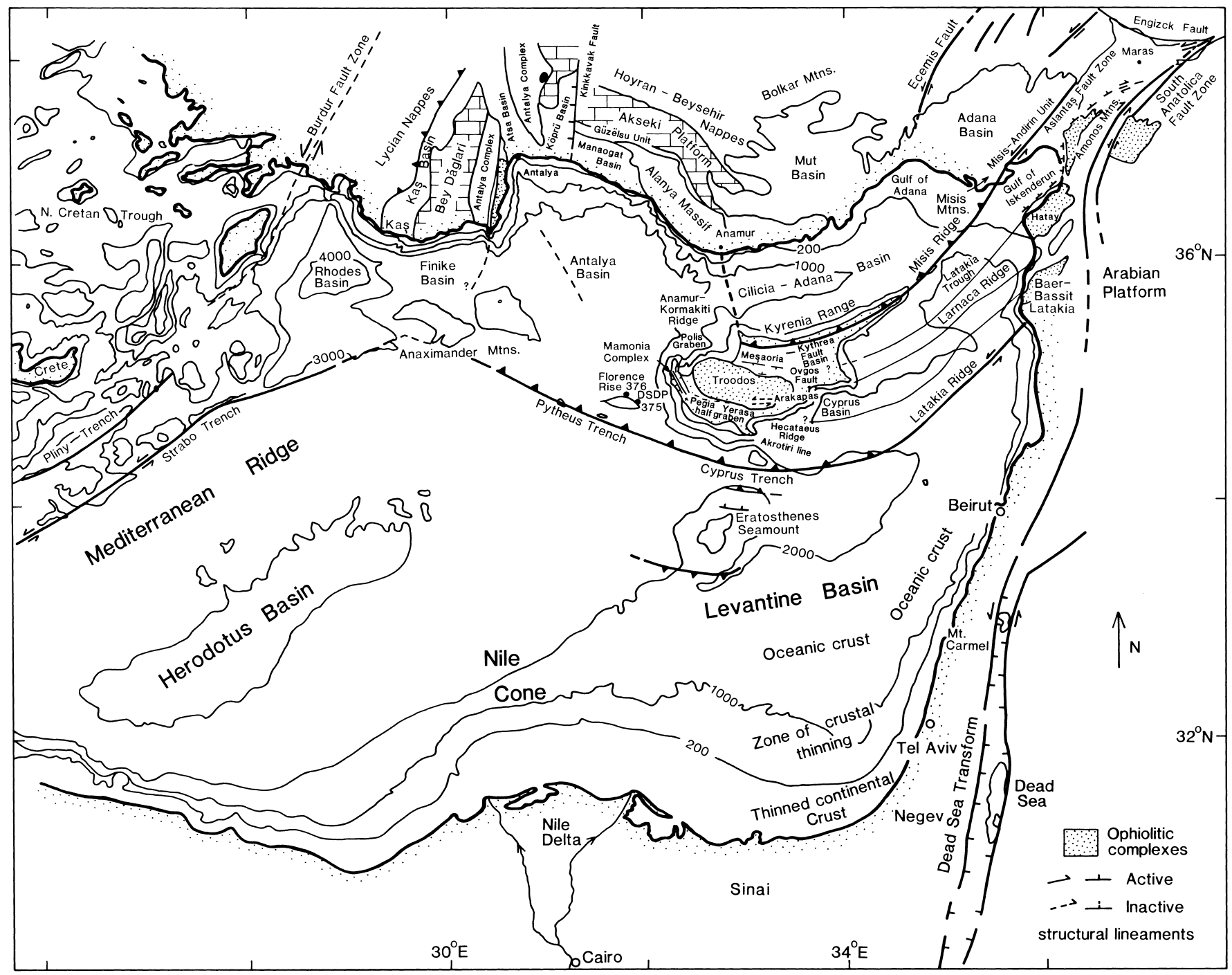

Figure 6. Outline tectonic map of the easternmost Mediterranean area extending from southwestern Cyprus to southern Turkey. Data sources are specified in the text.

the key evidence follows. Seismic refraction data indicate a crustal thickness, estimated at $40 \mathrm{~km}$ under the North African and Levant margins (Makris et al., 1983; Makris and Stobbe, 1984; Ben-Avraham and Tibor, 1994). Crustal thickness decreases from $>40 \mathrm{~km}$ in the northeastern Sinai and central Negev to $\sim 18 \mathrm{~km}$ toward the easternmost Mediterranean Sea (Fig. 6). The sedimentary cover increases from 2 to $\sim 9 \mathrm{~km}$ in this direction, consistent with a transition to oceanic crust in the northwest, overlain by a thick sedimentary cover. The floor of the Levantine Basin is underlain by crust that lacks the distinctive $6.0 \mathrm{~km} / \mathrm{s}$ layer and is thus more similar to oceanic than to continental crust (Ryan et al., 1973; Nur and Ben-Avraham, 1978; Makris et al., 1983; Makris and Stobbe, 1984). The Levantine Basin has, however, no known ordered magnetic anomalies (Ben-Avraham et al., 1976). The present coastline of Israel is underlain by a depositional hinge, marking a change from shallow to deeper water sediments from east to west. The axis of maximum thickness has migrated westward with time (Ginsburg and Gvirtzman, 1979), giving rise to a classic "steer's head" geometry of a subsiding passive margin. An important question is whether the Levant passive margin was orthogonally rifted, or dominated by strike slip as in many regional plate tectonic reconstructions (Smith, 1971; Dewey et al., 1973).
According to Garfunkel and Derin (1984), the geohistory of the Levant margin is typical of a subsiding passive margin (e.g., northeastern U.S.A.), but dissimilar to strike-slip passive margins, such as the Equatorial African margin. Strike-slip passive margins typically show a relatively narrow and steep profile, low subsidence rates (related to thermal and sediment loading), and less evidence of rift volcanism than orthogonally rifted margins (Scrutton, 1982; Anonymous, 1995).

Reprocessing of data collected by the Strakhov southwest of Cyprus supports the existence of oceanic crust dipping northeastward beneath Cyprus (Kogan and Stenin, 1994). This could not exist if the whole Levantine Basin was underlain by continental crust. By contrast to the Levant Basin, both Cyprus and the Eratosthenes Seamount are underlain by continental crust (Makris et al., 1983). The crust under Cyprus is estimated to be $36 \mathrm{~km}$ thick, whereas that under the Eratosthenes Seamount is reduced to $25 \mathrm{~km}$ (Lort, 1977; Woodside, 1977; Makris et al., 1983; Makris and Stobbe, 1984).

The regional patterns of gravity and magnetic data are complex and do not clearly delineate oceanic vs. continental domains (Ginsburg et al., 1993; Rybakov et al., 1994). However, study of seismic reflection data reveals a north-to-south contrast in the Levant margin 


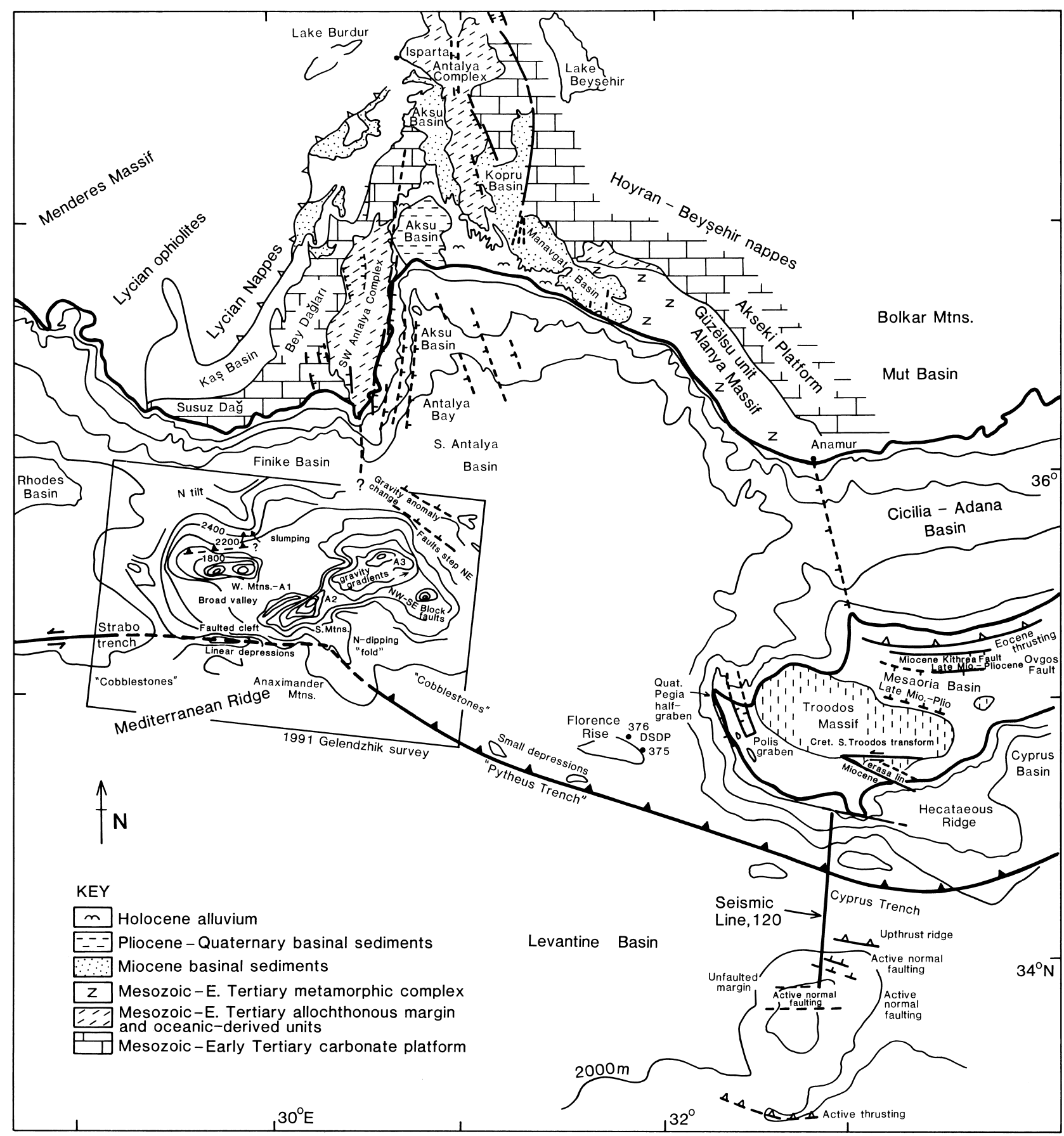

Figure 7. Outline bathymetric and geologic map of part of the easternmost Mediterranean area (detail of the area shown in Fig. 6). More detailed bathymetric data for the Anaximander Mountain area are included (from Ivanov et al., 1992).

(Ben-Avraham and Grasso, 1991; Ben-Avraham and Tibor, 1994). North of Mt. Carmel (Fig. 6), continental crust is inferred to extend to $10-15 \mathrm{~km}$ westward of the coast, followed by oceanic crust overlain by sediments estimated at $12 \mathrm{~km}$ thick. South of Mt. Carmel, the crust thins much more gradually over $\sim 150 \mathrm{~km}$. The Mt. Carmel area is marked by north-south gravity and magnetic gradients, delineating features that may relate to rifting. An important tectonic lineament also trends inland from the Mt. Carmel area (Ron et al., 1990).

In summary, the Eratosthenes Seamount is interpreted here as a continental fragment that was surrounded by oceanic crust within the present Levant Sea area during Mesozoic time. We now go on to dis- cuss, in turn, the four main north-south segments that straddle the present plate boundary, beginning with Segment 1 in the west (Fig. $5)$.

\section{SEGMENT 1: WESTERLY}

In the south, the westward extension of the Levantine Basin is inferred to comprise thick Tertiary and Mesozoic sediments underlain by oceanic crust, as described above (Fig. 7). 


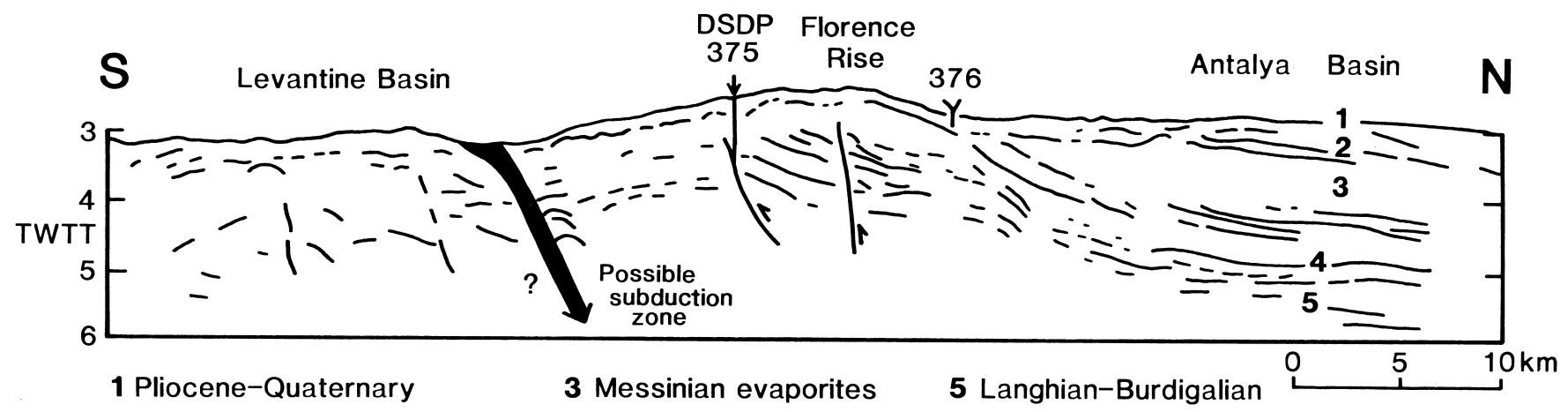

\section{Messinian marls and turbidites 4 Tortonian-Serravallian mudstones and turbidites}

\section{TWTT = Two-way travel time}

Figure 8. Seismic interpretation of offshore southwest Cyprus area. Structure of the Florence Rise according to Hsü, Montadert et al. (1978), and suggested reinterpretation as a sedimentary pile uplifted above a subduction zone, possibly transpressional (see Fig. 7 for locations of DSDP sites).

\section{Location of the Plate Boundary}

The Africa-Eurasia plate boundary is now well constrained to run approximately east-west between the Eratosthenes Seamount and Cyprus (Ambreseys and Adams, 1993; Kogan and Stenin, 1994; Emeis, Robertson, Richter, et al., 1996; Robertson et al., 1994, 1995c), and can be effectively taken as the location of a major northdipping fault zone, traditionally known as the Giermann Fault (Giermann, 1969). A graben-like feature at the foot of the Cyprus slope off southwest Cyprus could mark a southwestward extension of the Giermann Fault (Kempler and Ben-Avraham, 1987). Doubt persists as to the exact location of the westward extension of the plate boundary to the west of Cyprus, mainly because of the present lack of deep-penetration seismic data. This extension was thought to be marked by a chain of small basins, termed the "Pytheus Trench" by Anastasakis and Kelling (1991). Different authors show the plate boundary as either linking southwest Cyprus and the submarine Anaximander Mountains directly, or else trending subparallel to the coast of $\mathrm{Cy}$ prus, about $50 \mathrm{~km}$ offshore, and then running more east-west toward the Anaximander Mountains. Although still not well located in detail (see below), the preferred location of the boundary is shown in Figure 7 .

The Florence Rise is an elongate, gently elevated area extending west-northwest to east-southeast from off southwest Cyprus, and bordered to the southwest by the Pytheus Trench (Fig. 7). Available seismic reflection data (see Biju-Duval et al., 1977; Hsü, Montadert et al., 1978) suggest that the Florence Rise is a thick sediment pile, cut by seismic discontinuities that can be interpreted as reverse faults, or strike-slip faults. The Florence Rise is overlain by up to $150 \mathrm{~m}$ of semi-transparent Pliocene-Pleistocene sediments. Two holes on the Florence Rise drilled during DSDP Leg 42 (Sites 375 and 376; Fig. 7) revealed a varied Miocene succession of evaporites (including halite), pelagic carbonates and sands, although recovery by spot coring was very poor (Hsü, Montadert, et al., 1978). The base of the Pliocene succession shows evidence of slumping, suggestive of tectonic instability. A Messinian M reflector is well defined, both to the north and south, but it pinches out over the crest of the Florence Rise, indicating that it already existed as a topographic feature by the late Miocene. However, the presence of halite is surprising, as halite was formed only in Mediterranean deeps (Hsü et al., 1978; Montadert et al., 1978; Garrison et al., 1978). Possibly, this area was a deep basin or trench that only later became a ridge following tectonic uplift after the Messinian.

A possible origin of the Florence Rise is as a sedimentary pile uplifted above the leading edge of African plate related to northeastward subduction of Mesozoic oceanic crust within the Herodotus Ba- $\sin$ (Fig. 8). The Florence Rise could be interpreted as, in part, a small accretionary wedge dominated by Neogene fine-grained sediments including mud, pelagic carbonate, and evaporite. If correct, the plate boundary is located on the southern flank of the Florence Rise in the vicinity of the Pytheus Trench (Fig. 8). The Africa-Eurasia plate boundary in the vicinity of the Mediterranean Ridge further west was initially placed along the bathymetrically expressed Pliny and Strabo trenches (Ryan, Hsü et al., 1973), but was later re-positioned to the south of the Mediterranean Ridge, when improved seismic data became available, despite the absence of any bathymetric trench in this area (Kastens, 1981, 1992; Chaumillon and Mascle, 1994; Camerlenghi et al., 1995). Similarly, the plate boundary between the African and Eurasian plates south of the Florence Rise is not marked by any major trench.

\section{Western Cyprus, Offshore and Onshore}

Western Cyprus (Figs. 9, 10) is located within $20 \mathrm{~km}$ of the presently subducting slab (Kempler and Ben-Avraham, 1987; Ambreseys and Adams, 1993). Evidence from offshore and onshore indicates that western Cyprus has dominantly experienced crustal extension during Neogene-Holocene time. Collision in this segment of the Africa-Eurasia plate boundary (including southwestern Cyprus) is less advanced than in southern Cyprus and areas further east. Payne and Robertson (1996) invoked westward "tectonic escape" of this area away from a main collisional zone to the east, the Eratosthenes area, to help explain the presence of localized extensional structures in western Cyprus.

Seaward of the continental rise, offshore from southwest Cyprus, shallow seismic data reveal numerous ridges and crests and narrow "diapiric features" (Udintsev et al., 1994). In these areas, the Pliocene-Pleistocene sediment cover is disrupted by vertical faulting and possible evaporite diapirism, but deeper structure is not imaged. Near the base of the slope only superficial extensional features are imaged within Pliocene-Pleistocene sediments (Udintsev et al., 1994). Multichannel seismic data obtained during the cruise of Strakhov also reveal a small fault-controlled basin further north, off the Akamas Peninsula (Fig. 9), with an inferred Pleistocene sediment fill (Kogan and Stenin, 1994). These features are consistent with offshore southwest Cyprus being located in an extensional setting above a northward-dipping subduction zone.

Onshore, the sedimentary and structural setting of western Cyprus is well exposed as a result of regional Pliocene-Pleistocene uplift of the Troodos ophiolite and Cyprus as whole. Two features of the Neogene-Pleistocene geology of southwest Cyprus stand out. The first is an excellently developed flight of marine terraces that document 


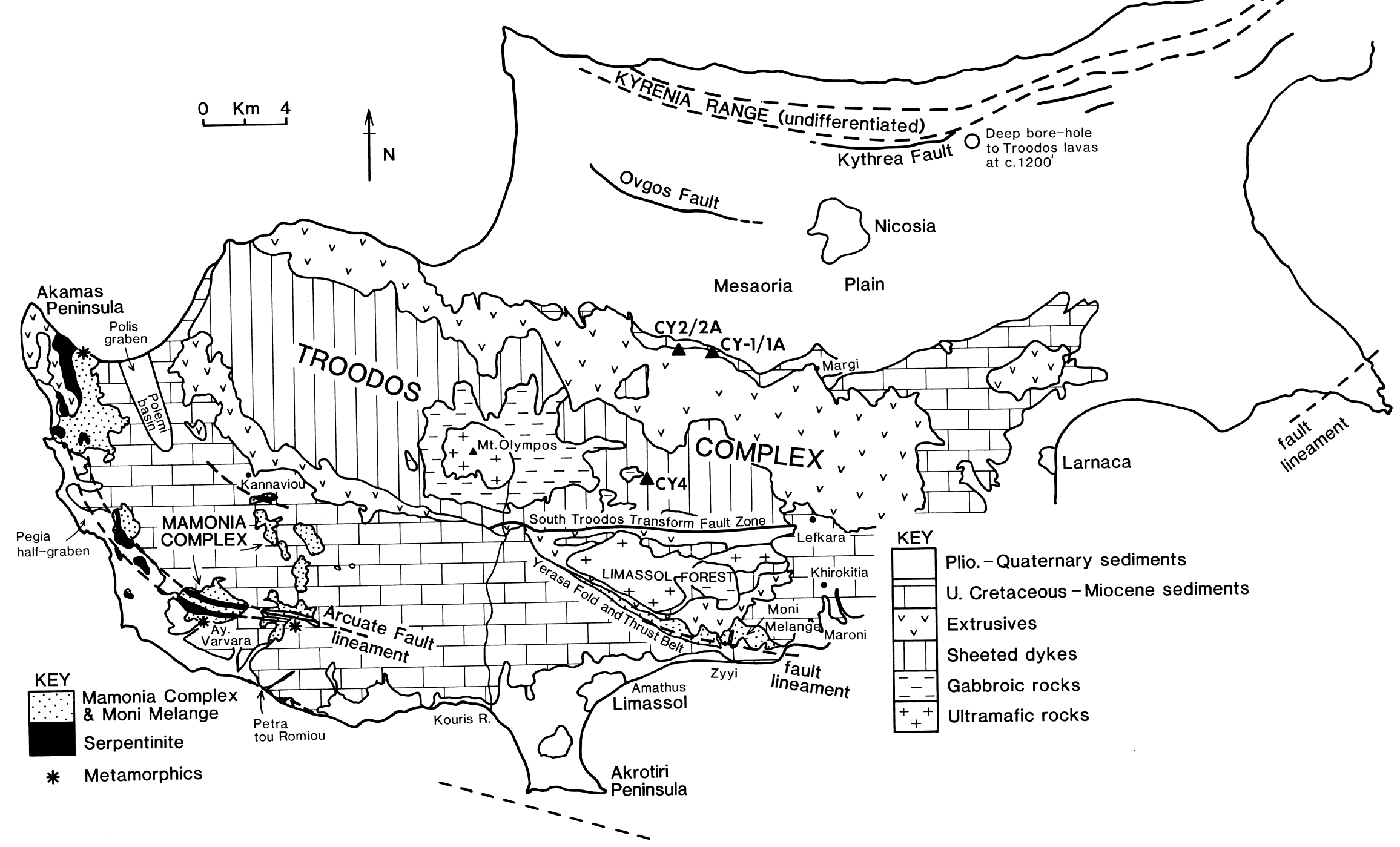

Figure 9. Outline tectonic map of Cyprus showing places mentioned in text. The three tectonic subdivisions are the Troodos Complex, the Mamonia Complex, and the Kyrenia Range. Modified after Robertson and Xenophontos (1993). Bathymetric features are shown in Figure 7. Solid triangles mark the sites of boreholes through the ophiolite drilled during the Cyprus Crustal Study Project. 


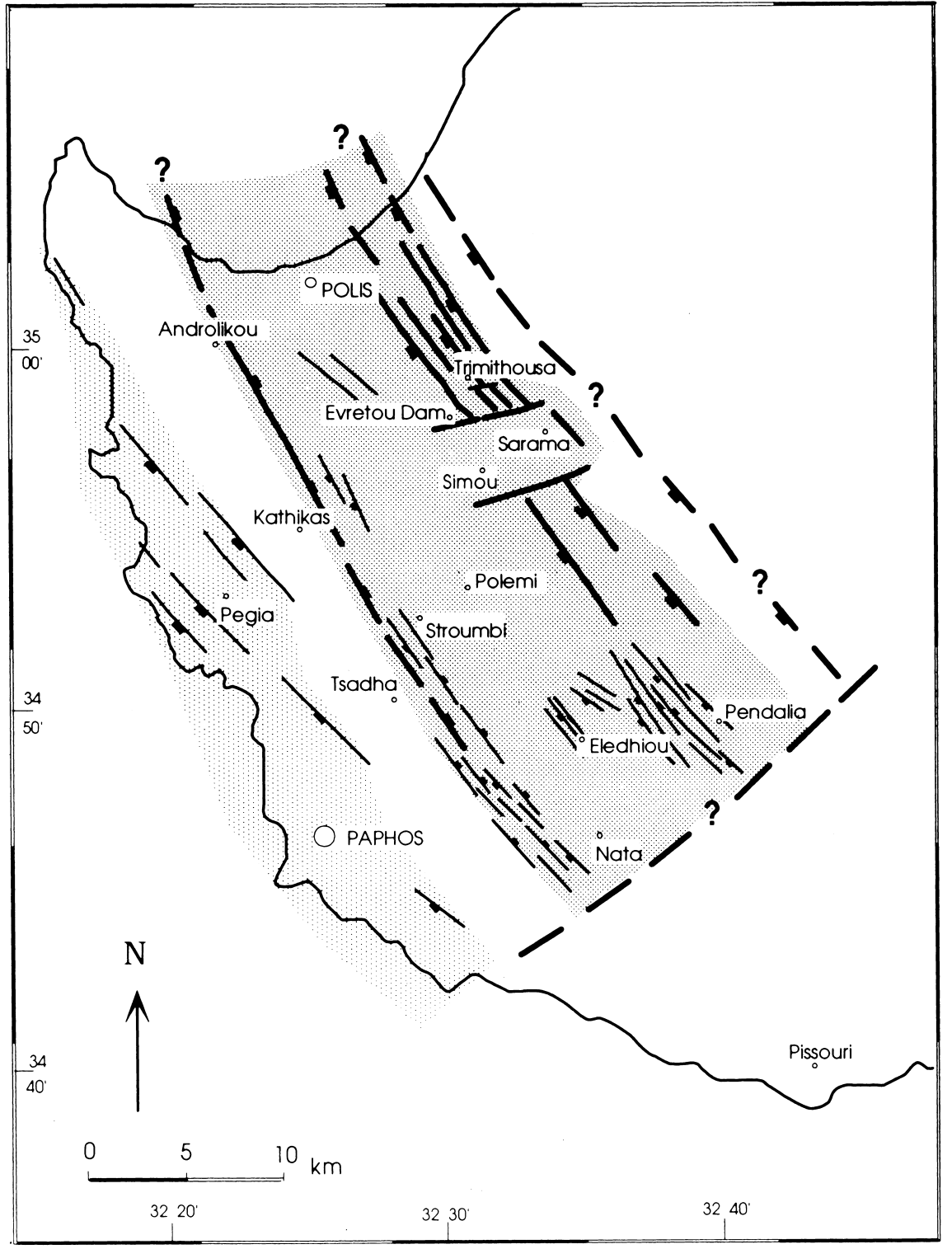

Figure 10. Map of Miocene-Holocene fault patterns in western Cyprus. The structure is dominated by the Miocene Polis graben, with a lesser role played by the late Pliocene-Pleistocene Pegia graben in the west; after Payne and Robertson (1996).
Pliocene-Pleistocene uplift (Poole et al., 1990; Poole and Robertson, 1992); the second is the presence of well-exposed Neogene to Pleistocene extensional basins (Payne, 1995; Payne and Robertson, 1996).

\section{Onshore Western Cyprus}

Higher Pleistocene terraces are progressively older, reflecting a dominant control of tectonic uplift over eustatic sea-level change throughout time. The highest terrace forms the crestal ridge of the Akamas Peninsula (Fig. 9) and is inferred to be of late Pliocene age (Payne, 1995). The next lowest terrace, at about $111-110 \mathrm{~m}$, is undated, but is inferred to be of early mid-Pleistocene age (Poole and Robertson, 1992). The next terrace down, at a height of 50-60 $\mathrm{m}$ is also undated. Below this, a terrace at a height of 8-11 m, contains the coral Chladochora sp. and has been dated at 185-204 Ma, using the Useries disequilibrium method (Poole et al., 1990). Below, the lowest exposed marine terrace at a height of $<3 \mathrm{~m}$, is dated at 116-134 Ma. Overall, the marine terraces relate to pulses of glacioeustatically driven marine transgression and regression, superimposed on a dominant influence of tectonic uplift. These marine terraces are offset by numerous small normal faults (with throws of up to $50 \mathrm{~cm}$ ). Analysis of fault patterns indicates a dominance of east-west extension (Poole, 1992). The dated marine terraces are at similar altitudes throughout southern and southeastern Cyprus and these were uplifted essentially as a coherent unit, without strong fault segmentation, as noted, for example, in the analogous above-subduction zone setting of Crete (Meulenkamp et al., 1988, 1994).

Two main structural features are present in western Cyprus: the coastal Pliocene-Pleistocene Pegia half-graben and the pre-existing Miocene Polis graben further inland (Payne and Robertson, 1996; Payne, 1995; Fig. 10). The Pegia half-graben developed in the Pliocene-Pleistocene by down-to-the-west extensional faulting of the present coastal area, up to about $12 \mathrm{~km}$ wide. Exposed normal faults trending nearly north-northwest to south-southeast are interpreted as the footwall of a half-graben. Some extensional faults cut late Pleistocene-Holocene sediments and are probably still active. The hanging wall of the Pegia half-graben is inferred to be located offshore.

Further inland, western Cyprus is dominated by the north-northwest-east-southeast asymmetric Polis graben (Fig. 10). Normal faulting along the axis of this graben is probably still active, as late Pleistocene-Holocene fluvial conglomerates, including paleosols, are lo- 
cally cut by high-angle faults (Payne and Robertson, 1996). The fill of the Polis graben is mainly composed of early to middle Pliocene marine calcareous muds up to several hundred meters thick. Both the Troodos ophiolite to the east and the small Akamas Peninsula area to the west (Fig. 10) were emergent during the Pliocene, feeding clastic sediments as small fan deltas into a shelf-depth sea within the Polis graben. The marine muds pass upward into shallow-marine bioclastic carbonates of late Pliocene age. Regional uplift of the Polis graben in the late Pliocene-Pleistocene time resulted in emergence and progressive downcutting, leading to the deposition of channelized fluvial conglomerates, mainly derived from the rising Troodos ophiolite to the east. The fluvial channels exploited pre-existing structural lineaments, particularly the structural grain of the Polis graben.

The Polis graben originated as a regionally important structural feature in the late Miocene time. Tortonian reefs (Koronia Member) developed along the western and eastern margins of the developing graben (Follows, 1990, 1992; Follows et al., 1996). Late Miocene sediments, including Tortonian reef-limestones, Messinian evaporites and rare fluvial clastics were cut by extensional faults and then sealed by early Pliocene open-marine sediments in the northern part of the graben.

During the Messinian, gypsum (but not halite) precipitated in the southern part of the Polis graben, known as the Polemi basin (OrszagSperber et al., 1989; Robertson et al., 1995a). The Polemi basin (Figs. 9,10 ) is reconstructed as a structural depression at the southern end of the Polis graben that was bounded to the southeast and northwest by graben bounding faults, and to the northeast and southwest by transverse faults (Payne, 1995; Payne and Robertson, 1996; Fig. 10).

Two gypsum units are present within the Messinian Polemi basin. The lower of these units, basinal gypsum, is overlain by an extensive gypsum "mega-breccia" unit, up to 25 m thick. "Mega-breccias" are again exposed in southern Cyprus above similar basinal gypsum. These "mega-breccias" were probably tectonically triggered. In west Cyprus additional gypsum overlies the "mega-breccias." In one area of southwestern Cyprus (Pissouri area, Fig. 10), the gypsum passes laterally and upward into paleosols, sands, and conglomerates of late Messinian age (Orszag-Sperber et al., 1989; Robertson et al., 1995a).

The presence of gypsum "mega-breccia" in southern and western Cyprus is intriguing. They were apparently the result of en masse foundering related to uplift or tilting. The Leg 160 results provide evidence that the Eratosthenes Seamount was impinging on the Cyprus active margin to the south at least by earliest Pliocene time. It is, thus, possible that collapse of early gypsum basins was triggered by initial collision of the Eratosthenes Seamount with southern Cyprus.

The Messinian evaporites are underlain by gypsiferous marls, organic-rich sediments, and local stromatolitic deposits, forming the upper part of the Miocene Pakhna Formation. During the early Miocene, peripheral areas saw development of reef limestones and related off-reef facies (Follows, 1990, 1992; Follows et al., 1996). These early Miocene reefs predate formation of the Polis graben in the late Miocene.

Underlying pelagic carbonates of Maastrichtian-lower Eocene age (Lefkara Formation) up to several hundred meters thick are preserved only in the south of the area (western Cyprus), while upper Eocene-Oligocene pelagic carbonates are preserved only as remnants further north (e.g., in the Akamas Peninsula and west Troodos margin; Kluyver, 1969; Payne, 1995). Maastrichtian-lower Eocene deep-water pelagic carbonates were not deposited in northerly areas, or they were later eroded. Recent work confirms that the Akamas Peninsula area formed a persistent topographic high during Maastrichtian and early Tertiary time (T. Morse, pers. comm., 1996; Payne, 1995). The early Tertiary Lefkara Formation accumulated in a broad basin between the Troodos ophiolite to the east and a smaller "Akamas ridge" to the west.

In summary, western Cyprus records latest Cretaceous to Oligocene basinal pelagic carbonate deposition, followed by extensionrelated sedimentation in the late Miocene.

\section{Mesozoic "Basement" of Western Cyprus}

In southwestern Cyprus the Upper Cretaceous and Tertiary carbonates are underlain by "basement terrains," known as the Mamonia Complex (Fig. 9), that are of extreme structural complexity (see Robertson and Xenophontos, 1993 for a summary). A brief resumé is essential here, however, as these units include critical evidence of early Mesozoic oceanic crust and deep-sea sediments within the easternmost Mediterranean area. Specifically, the Mesozoic geology of southwestern Cyprus includes evidence of Late Triassic Mid-ocean ridge-type (i.e., MORB) volcanics (Malpas et al., 1993), radiolarian cherts, and pelagic limestones. Second, the Mamonia Complex includes remnants of a deep-water sedimentary passive margin succession that bordered Neotethys during the Mesozoic (Robertson and Woodcock, 1979). Third, the Mamonia Complex provides evidence of a destructive plate margin (suture zone) that predated the present Africa-Eurasia plate boundary (the Cyprus active margin). This active margin was probably related to regional northward subduction of Neotethys in the easternmost Mediterranean. Current research centers on the Late Cretaceous-early Tertiary history of this destructive margin, especially the relative importance of thrusting vs. strike slip that culminated in the tectonic juxtaposition of the Mamonia Complex with the Troodos ophiolite.

Three main Mesozoic units are recognized in western Cyprus. First, in the east there is the Late Cretaceous Troodos ophiolite and its sedimentary cover. In western Cyprus this cover unit is dominated by unusual volcaniclastic sediments, up to $750 \mathrm{~m}$ thick, the Kannaviou Formation (Robertson, 1977a) that is Campanian in age (Urquart and Banner, 1994). This formation includes volcanic glass of calcalkaline composition (Clube and Robertson, 1986). However, no evidence of the parent arc volcanism is preserved in southwestern Cyprus. The Kannaviou Formation either records activity of a continental margin arc, possibly within southern Turkey (for which there is no known evidence), or it relates to more local incipient intra-oceanic arc volcanism (Clube and Robertson, 1986). In either case, the Kannaviou volcaniclastic sediments support the existence of arc volcanism associated with a Late Cretaceous destructive plate boundary within the region.

Second, several arcuate structurally complex lineaments sweep through west and south west Cyprus (Fig. 9). These lineaments originated before accumulation of overlying Tertiary pelagic chalks and include Upper Cretaceous ophiolitic rocks, deformed earlier-Mesozoic sedimentary, igneous rocks, and localized metamorphic rocks. The lineaments are widely interpreted as the westward extension of a prominent east-west-trending elongate feature within the Upper Cretaceous ophiolites further east (Robertson, 1990), known as the South Troodos Transform Fault Zone (MacLeod, 1990). This feature is interpreted as a fracture zone (i.e., transform fault) within the Troodos ophiolite (Gass et al., 1994). Distinctive units that characterize these arcuate lineaments in western and southwest Cyprus include ophiolite-derived clastic sediments, mafic, and ultramafic units emplaced to high levels, sheared serpentinites, and unusual high-magnesian (boninite type) lavas (Malpas et al., 1992, 1993). Further information on the South Troodos Transform Fault Zone is included in the description of Segment 2. The ophiolitic lineaments in western Cyprus include discontinuous units of amphibolite and greenschist facies metamorphic rocks, showing evidence of shearing in a progressively evolving ductile to brittle regime (e.g., at Ayia Varvara; Robertson and Woodcock, 1979; Spray and Roddick, 1981; Malpas et al., 1992, 1993).

Third, there is a structurally higher unit that is wholly sedimentary, the Ayios Photios Group, of Late Triassic to Early Cretaceous age (Swarbrick and Robertson, 1980). This is comprised of highly tectonically disrupted thrust sheets, transitional to tectonic mélange, but with no sedimentary matrix ("broken formation"). Partial successions can be pieced together in different areas and then correlated to produce an overall composite succession (Lapierre, 1972; Robertson 
and Woodcock, 1979). This begins with Late Triassic quartzose sandstone turbidites and local pelagic limestones, and then passes into Jurassic-Lower Cretaceous redeposited shallow-water limestones, sandstone turbidites, radiolarian mudstones, and radiolarites. Dating is mainly based on calcareous fossils including pelagic bivalves (e.g., Halobia sp.), rare ammonites, benthic and planktonic foraminifers, and radiolarians. Facies variations within individual tectonically bounded units reflect original proximal to distal depositional changes. There is an important interval of quartzose sandstone of Lower Cretaceous age. The sedimentary succession (Ayios Photios Group) is interpreted as part of the tectonically disrupted deepwater passive margin of the southerly Neotethyan oceanic basin (Fig. 11). Deposition persisted from Late Triassic to post-Early Cretaceous time, during which passive margin subsidence took place adjacent to a spreading axis, although spreading was probably not continuous (Robertson and Woodcock, 1979). More proximal slope and shelf deposits and continental basement are not preserved in western and southwestern Cyprus, but equivalent units are present in the Kyrenia Range of northern Cyprus, and in southern Turkey (Fig. 6). No in situ basement to the Ayios Photios Group sediments is exposed in southwest Cyprus, but in the comparable Antalya Complex of southwest Turkey similar Mesozoic deep-water sediments depositionally overlie Late Triassic extrusives of transitional to MORB type (Robertson and Woodcock, 1982; Robertson and Waldron, 1990).

The fourth and final unit of the Mamonia Complex, the Dhiarizos Group, is located structurally beneath the Ayios Photios Group, and is dominated by mafic extrusives of Late Triassic age. The extrusives are of two contrasting geochemical types. First, MOR basalts discovered by Malpas et al. $(1992,1993)$ are locally interbedded with deepwater Triassic Halobia-limestones and ribbon radiolarites, and are locally overlain by radiolarian sediments, thin-bedded redeposited limestones, and shales (Swarbrick and Robertson, 1980). Second, there are common alkaline, within-plate type lavas that are associated with blocks of Late Triassic shallow-water limestones, including reef limestone (e.g., at Petra tou Romiou; Fig. 9). Both lava types have counterparts in the Antalya Complex of southwestern Turkey (Robertson and Woodcock, 1982; Robertson and Waldron, 1990; Robert- son, 1993), while Late Triassic alkaline lavas are also known from the comparable Baer-Bassit area of northern Syria (Delaune-Mayere et al., 1976; Delaune-Mayere, 1984).

In summary, the sedimentary rocks of the Mamonia Complex are interpreted as deep-water base-of-slope facies of a Mesozoic passive continental margin. The volcanic rocks represent oceanic crust and seamounts capped by carbonate buildups that formed in the Late Triassic during formation of a small southerly Neotethyan ocean basin.

Still controversial is how the Late Cretaceous Troodos ophiolite, and the earlier Mesozoic sedimentary and volcanic rocks of the Mamonia Complex were tectonically juxtaposed. The assembly is inferred to have taken place in the vicinity of the boundary of a small plate, known as the Cyprus microplate (Clube and Robertson, 1986). The limited age information is suggestive of an essentially two-stage development (Fig. 12).

The first stage, at about 93-90 Ma, involved genesis of amphibolite (and greenschist) metamorphic rocks, that are now tectonically intercalated with the arcuate lineaments (Spray and Roddick, 1981). Possible origins of these metamorphic rocks include: (1) deformation of a young oceanic transform (transpression; Spray and Roddick, 1981), or (2) underplating of oceanic material to the base of an overriding slab of young, hot, oceanic lithosphere within a subduction zone setting, as inferred for other Tethyan subophiolitic metamorphic rocks (Woodcock and Robertson, 1977; Searle and Malpas, 1980; Whitechurch et al., 1984; Malpas et al., 1993). The formation of the amphibolites and greenschists is likely to relate to initiation of intraoceanic subduction within the Neotethys around 90-93 Ma and underplating of Neotethyan mafic crust and deep-sea sediments to the base of a slab of young hot Upper Cretaceous oceanic lithosphere that was possibly formed above a subduction zone near a transform fault (Fig. 12B).

During the second stage (Maastrichtian), the Mamonia Complex and the Troodos ophiolite were tectonically juxtaposed. Alternative processes for this are (1) gravity sliding of passive margin units followed by thrust interleaving of Troodos- and Mamonia-related units (Robertson and Woodcock, 1979); (2) emplacement by mainly dextral strike slip (Clube and Robertson, 1986; Fig. 12C); and (3) em-

\section{LATE TRIASSIC}

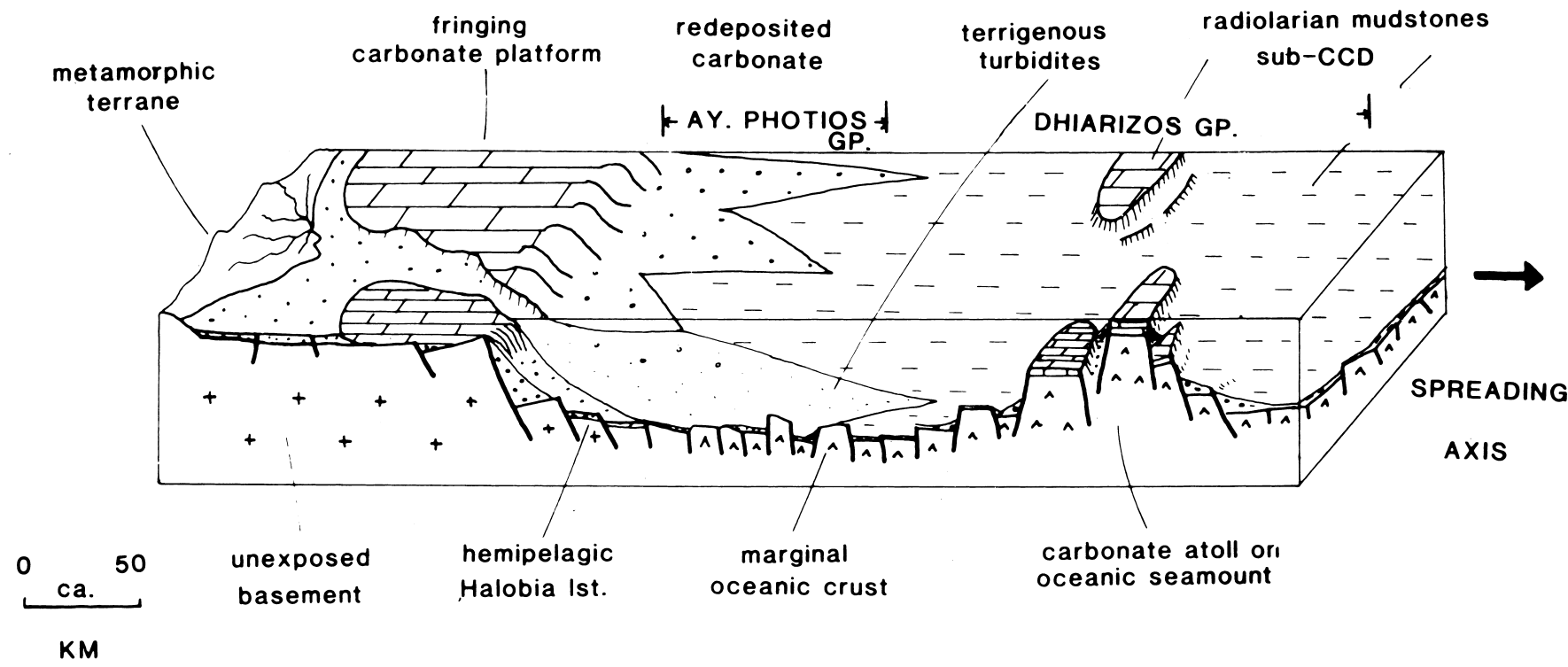

Figure 11. Reconstruction of the Mamonia Complex, southwest Cyprus. Upper Triassic remnants of the margins of a small oceanic basin bordered by a passive margin. This margin formed part of a microcontinent rifted from Gondwana, probably located along the northern margin of the southerly Neotethys; see text for further explanation. 


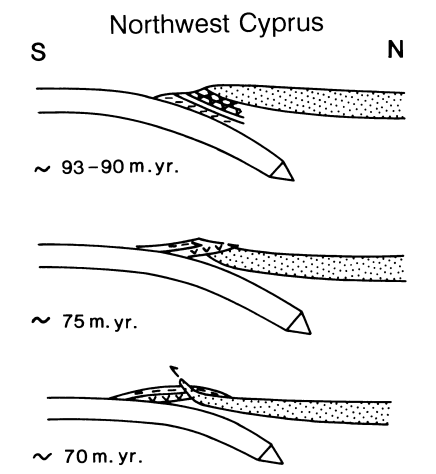

Figure 12. Alternative reconstructions of the tectonic setting of emplacement of the Mamonia Complex, western Cyprus and Moni mélange, southern Cyprus. A. Emplacement of the Mamonia Complex against the Troodos Ophiolite by subduction-accretion, thrusting and backthrusting (Malpas et al., 1992). B. Emplacement initiated by collapse of an oceanic transform fault, followed by subduction-accretion (Robertson, 1990). C. Interleaving of Troodos and Mamonia rocks by strike-slip faulting (Swarbrick, 1980). The sense of strike slip is controversial, but is here accepted as dextral, related to paleorotation of the Troodos microplate (Clube and Robertson, 1986). D. Genesis of the Moni mélange by sliding of continental margin blocks from an uplifted (transpressional) strike-slip lineament, part of the boundary of the Troodos microplate (Clube and Robertson, 1986).

\section{A Multiphase thrusting}

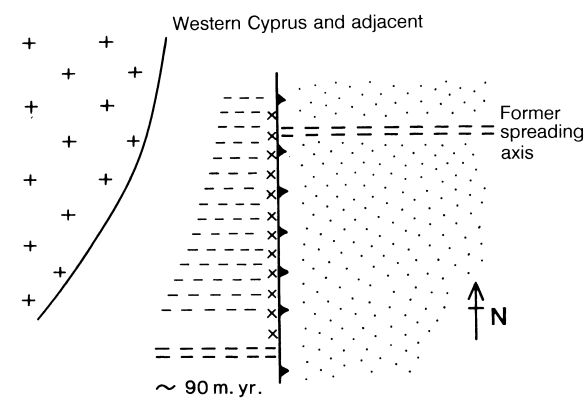

B Dextral transpression of
Southwest Cyprus

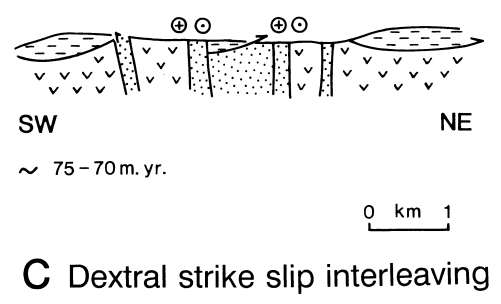

KEY
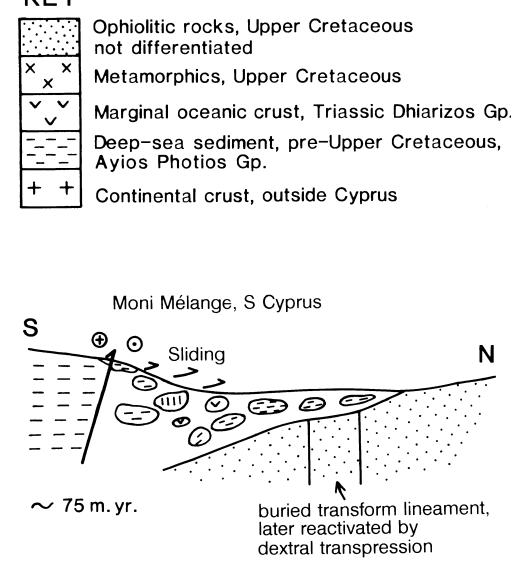

D placement by mainly sinistral strike-slip (Swarbrick, 1980, 1993; and (4) emplacement by orthogonal compression (Malpas et al., 1993; Fig. 12A).

Malpas et al. (1993) postulated the following series of events (Fig. 12A) during emplacement of the Mamonia Complex: (1) thrust imbrication as an accretionary wedge in a trench-forearc setting related to subduction; (2) thrusting of the accretionary prism across Upper Cretaceous ophiolitic crust (i.e., across the inferred location of the trench); and (3) backthrusting of the Upper Cretaceous ophiolitic rocks (oceanward) over the previously emplaced accretionary prism to produce the arcuate ophiolitic lineaments within west and southwest Cyprus. Additional structural studies are currently being carried out in western Cyprus to try to resolve these controversies (Bailey, 1996).

The complicated structure of the Mamonia can be more easily explained by a combination of dextral strike-slip and thrusting. This deformation took place in the vicinity of a microplate undergoing counterclockwise rotation (Clube et al., 1985). The main evidence for this microplate is that the Troodos ophiolite underwent counterclockwise rotation of $\sim 90^{\circ}$ (Moores and Vine, 1971), during Late Cretaceousearly Tertiary time (Clube et al., 1985). The boundaries of the microplate are inferred to be located in the vicinity of the sutured units within Cyprus (onshore and offshore; Clube and Robertson, 1986).

The Mamonia allochthonous units in western Cyprus need to be restored clockwise by $90^{\circ}$ to reach their Late Cretaceous coordinates based on the paleomagnetic data. The rotated crust includes tectonically bounded slivers of Late Cretaceous ophiolitic rocks in the extreme northwest of Cyprus (Akamas Peninsula; Fig. 9). It is probable that the Mamonia rocks should also be restored by up to $90^{\circ}$ clockwise to reach their original position. This in turn implies that the Mesozoic Mamonia continental margin rocks were originally located to the northwest or north of their present location, and thus represent part of the northern passive margin of the Neotethys in the Easternmost Mediterranean. Similar early Mesozoic continental margin units are found in southern Turkey (Antalya Complex) and can be interpreted in the same way (see later discussion).

\section{Anaximander Mountain Offshore Area}

The following section provides an account of the northward continuation of Segment 1 under the Mediterranean Sea and into southern Turkey. The present-day Africa-Eurasia plate boundary is inferred to swing north-northwestward from southern Cyprus, and then to connect with the westward extension of the Mediterranean Ridge in the vicinity of the submarine Anaximander Mountains (Ivanov et al., 1991; Woodside, 1992). Between Cyprus and the Anaximander Mountains the plate boundary between Africa and Eurasia remains poorly constrained, but the surface expression of the plate boundary is probably located southwest of the Florence Rise in the vicinity of the Pytheus Trench. Westward again, the linkage between the plate boundaries of the Aegean and Cyprus "arcs" has long remained obscure. Recent work indicates that this is because stress is accommodated across a broad zone, including the strike-slip dominated Strabo and Pliny trenches and other fault lineaments (Chaumillon and Mascle, 1995, in press; Figs. 6, 7).

At its most northerly extent, the Florence Rise is marked by northwest-southeast-trending bathymetric features, defining a hummocky cobblestone-type topography (Fig. 7). Farther northwest, the Anaximander Mountains comprise three main submarine highs, termed A1 (Anaximander), A-2 (Anaximenes), and A-3 (Anaxogoras) from west to east (Woodside et al., 1992, Woodside and Dumont, 1997). The zone of intersection between the Florence Rise and the A-3 high in the east is marked by a northwest-southeast-trending synclinal structure and block faulting, possibly reflecting upthrusting and compression. The A-3 high is a northwest-southeast-trending faulted ridge on a broader plateau of irregular relief. Dredging the A-3 area has confirmed the presence of lithologies typical of the Mesozoicearly Tertiary carbonate platform (Susuz Dağ) and allochthonous 
rocks (Antalya Complex) of southern Turkey, including limestone, turbiditic sandstone, ophiolitic rocks, and radiolarian chert. Seismic evidence does not indicate the presence of evaporite, suggesting that the intervening basins are essentially post-Messinian age. The northeastern margin of the A-3 high is marked by several northwest-southeast-trending fault lineaments that step down eastward into the southern Antalya Basin. Compression toward the northeast has resulted in formation of a fold lineament bordering the adjacent southern Antalya Basin. Bouguer and free air gravity anomaly gradients change abruptly across the northeastern margin of the A-3 high along faults delineating the western edge of the southern Antalya Basin.

The A-3 high passes westward into the A-2 structure, a curved ridge of dipping $\left(25^{\circ}\right)$ sedimentary units. The transition is marked by tilting and bending of the A 2 high to the northwest. The A- 1 high, the most northwesterly, is separated from the A-2 high by a broad gentle valley. A-1 is a gently northward-tilted $\left(4^{\circ}\right)$ tabular block. It appears that the A-2 high is being thrust beneath A-1 causing rapid uplift (Woodside and Dumont, 1997). The northern margin of A-1 high is marked by large-scale slumping toward the north and young upthrusting toward the west-southwest (Woodside et al., 1992). Further west, the A-1 high passes northwestward into the deep Finike Basin $(3000 \mathrm{~m})$ that appears to be tilted to the north. The boundary between the Finike Basin and the Turkish coast is a steep fault zone. The Finike Basin passes eastward into the deep Rhodes Basin (4000 m), which in the past has been interpreted as a young rifted basin (probable), or as stranded Mesozoic oceanic crust (Mascle et al., 1986). The western margin of the Rhodes basin is marked by an important lineament, the Pliny trench, and its onshore extension, the Burdur Fault Zone.

The area to the west of the Anaximander Mountains connects with the Mediterranean Ridge accretionary complex, via a series of fault lineaments dominated by left-lateral strike slip. The southern boundary of the A-1 high is marked by a prominent east-west linear depression ("cleft" area), marked by downfaulting, that is especially marked on the northern side. The "cleft" lineament passes westward into the Strabo Trench. The Mediterranean Ridge to the south is marked by cobblestone topography. The "cleft" lineament passes eastward into a broad fold structure that exhibits sediment deformation on sidescan sonar images (Ivanov et al., 1991; Woodside, 1992).

The dredge results prove that the Anaximander Mountains formed an extension of southern Turkey in the Mesozoic and early Tertiary. Regional northward subduction presumably took place beneath this in Neogene time, as along the Aegean and Cyprus arcs. However, the former forearc area (south of Turkey) was later disrupted in a strikeslip-dominated regime. Initial deformation was perhaps mainly transtensional, opening the Finike and Rhodes basins, but switched to transpressional in the Pleistocene, marked by collision of the A-2 and A-3 highs and folding of the adjacent margin of the Antalya Basin. The Antalya Basin had formed earlier (Miocene) as an extensional basin. The strike-slip setting of the Anaximander Mountain area linking the Aegean and Cyprus arcs, has similarities with the area linking Cyprus and the Levant margin; this is also interpreted as a broad strike-slip dominated plate boundary (see later). The setting of the Anaximander Mountains area should be clarified when much recently acquired survey data are published.

Further west, the Mediterranean Ridge has recently been shown to be a mud-dominated accretionary wedge, related to northward (or northeastward) subduction of Mesozoic oceanic crust probably since late Oligocene time (Kastens, 1981; Camerlenghi et al., 1995; Chaumillon and Mascle, 1995, in press; see Robertson and Kopf, Chap. 50, this volume, for discussion of regional setting). In its central area, the Mediterranean Ridge is now in the process of collision with Cyrenaica, a large promontory of North Africa. However, further east in the Herodotus Basin area, and west in the Ionian Sea, collision has not yet occurred. Small remnants of Mesozoic oceanic crust remain, overlain by very thick sediments. The Hellenic Trench, between the Mediterranean Ridge and Crete, was first postulated to be the present-day Africa-Eurasia plate boundary (e.g., Hsü, 1978), but more recently has been re-interpreted as a flexural foredeep related to backthrusting of the Mediterranean Ridge accretionary complex (Camerlenghi et al., 1995). In the east, the Hellenic fore-arc zone includes the discrete Strabo and Pliny trenches. It is widely believed that these features are dominated by left-lateral strike-slip (e.g., Le Pichon and Angelier, 1979; Angelier et al., 1982). The Pliny trench extends onshore as the important left-lateral Fethiye-Burdur fault zone, while the Strabo Trench extends eastward into the "cleft" area south of the western Anaximander Mountains (A-1 high).

In summary, the Anaximander Mountains are interpreted as a submarine extension of tectonic units exposed on land in southwestern Turkey (see below). There is no evidence to support a recent suggestion that Anaximander is a continental fragment rifted from North Africa (Barka et al., 1997). Their complex structure, including localized reverse faulting in the northwest, folding in the southeast and faultrelated subsidence in the northeast, accommodates the intersection of a zone of left-lateral displacement, or transpression, located within the Strabo trench with an inferred northeastward-dipping zone of subduction or transpression beneath the Florence Rise. The deep Finike and Rhodes basins probably originated as above-subduction zone rifted basins, and are similar to the Adana and Cilicia basins further east (see below). These basins are now being actively deformed, in response to left-lateral transpressional deformation along the plate boundary to the south.

\section{Onshore Southwest Turkey: Pliocene-Quaternary Antalya Bay and Miocene-Pliocene Aksu Basin}

The deep structure of Antalya Bay (Fig. 7) remains poorly known. Seismic data indicate the presence of evaporites of presumed Messinian age and, thus, imply a pre-Messinian age of formation (Woodside, 1977). Earthquake records suggest the existence of a detached oceanic slab beneath Antalya Bay (Rotstein and Kafka, 1982; Jackson and McKenzie, 1984), although the direction and timing of subduction remain unclear. Shallow-penetration seismic data made available by M. Ergun (pers. comm., 1994) for the northern Antalya Bay area indicate that the western margin of Antalya Bay is marked by a series of steep down-to-the east normal faults (Glover, 1996). The northeastern Antalya Bay area is characterized by more widely spaced faults that locally define a horst and graben structure (Glover, 1996; Glover and Robertson, 1998). Extensional faulting has produced a southward-widening rift basin (Antalya Basin) within the Antalya Bay area (Fig. 7). This basin is tentatively interpreted as the result of crustal extension behind a subduction zone linking the Florence Rise with the southern boundary of the Anaximander Seamount (Fig. 7).

The northern Antalya Bay area extends onshore as the PliocenePleistocene Aksu Basin. The Pleistocene record of the Aksu Basin (Fig. 7) is marked by extensive tufa deposits ("Antalya travertine"; Bürger, 1990) that precipitated from cool-water springs (Glover, 1996). The Antalya tufa was built up on a thin (tens of meters) late Pliocene to early Pleistocene alluvial succession. Beneath this, a Messinian to mid-Pliocene extensional basin is infilled with shallowmarine to deltaic sediments up to several hundred meters thick (Glover, 1996). Messinian evaporite is very locally present onshore within the Aksu Basin. The Pliocene-Pleistocene Aksu Basin is interpreted in terms of an initial late Miocene transtensional rift event, followed by an early to mid-Pliocene sedimentary infill, followed by further rifting and extension in the latest Pliocene-early Pleistocene (Glover and Robertson, 1993; Glover and Robertson, 1998) that was associated with uplift of the adjacent Taurus Mountains, and was more generally linked to regional crustal extension and uplift of western Anatolia as a whole (Price and Scott, 1994).

The onshore Pliocene-Pleistocene succession rests unconformably on older sediments of the Miocene Aksu Basin (Akay et al., 1985, Fig. 7). This basin is dominated by middle-late Miocene mud- 
stones, turbidites, and channelized conglomerates, interpreted as coarse clastic sediments shed from the front of the Lycian Nappes as they neared their final position (Flecker, 1995; Flecker et al., 1995). The floor of the Miocene Aksu basin was strongly faulted during sedimentation, possibly exploiting pre-existing lineaments within the underlying Mesozoic Antalya Complex (Flecker, 1995). During the late Miocene, allochthonous units (Lycian Nappes, see below) were thrust to their final position, deforming early Miocene foreland basin sediments in the north. Also during the late Miocene, the easterly margin of the Aksu basin was deformed by reverse-faulting, thrusting, and folding toward the west ("Aksu phase" of Poisson, 1977; Akbulut, 1977). This deformation was generally coeval with counterclockwise rotation of the western limb of the Isparta Angle and clockwise rotation of the eastern limb of the Isparta Angle (Kissel et al., 1990; Kissel and Poisson, 1986; Morris and Robertson, 1993). The Isparta Angle is interpreted as a Mesozoic oceanic basin (with oceanic crust) that separated several large carbonate platforms during the Mesozoic-early Tertiary (Poisson, 1984; Waldron, 1984; Robertson, 1993). The Isparta angle was tightened to form an "oroclinal bend" during the Miocene related to regional development of the southward curvature of the Aegean active margin (Kissel and Laj, 1988). It was influenced by the final emplacement of the Lycian Nappes toward the southeast, and possibly also by westward movement of Anatolia caused by collision with the Arabian margin in southeastern Turkey. At present the centre of the Isparta Angle is undergoing little or no relative motion compared with central and western Anatolia, which is being expelled westward (Barka et al., 1997).

\section{Onshore Isparta Angle and the Mesozoic Antalya Complex}

The Antalya Complex has a regional northward-pointing Vshaped outcrop pattern, defining the Isparta Angle (Fig. 13). The Antalya Complex is a regionally important unit of mainly Mesozoic allochthonous rocks (Delaune-Mayere et al., 1976) that was finally emplaced westward onto a small Miocene foreland basin succession overlying shallow-water carbonates (Susuz Dağ) in the late Miocene (Hayward and Robertson, 1982). However, in the north (near Isparta, Fig. 13), the Antalya Complex is transgressed by lower Miocene limestones and terrigenous turbidites, and is then overthrust by the leading edge of the Lycian Nappes showing that the Antalya Complex and the Lycian Nappes were emplaced at different times (Poisson, 1977; Gutnic et al., 1979). The Antalya Complex has affinities with the Mamonia Complex of western Cyprus, and is critical to tectonic interpretation of the easternmost Mediterranean during Mesozoic and Tertiary time.

The Antalya Complex is divided into a number of segments exposed in different parts of the Isparta Angle (Robertson, 1993). The area adjacent to Antalya Bay (known as the Southwest area) is the best exposed and most documented part of the Antalya Complex, as summarized below. The following main units are present from west to east (Robertson and Woodcock, 1982; Fig. 13B): First, there is the relatively autochthonous Mesozoic Bey Dağları carbonate platform that locally is overlain by Miocene foreland basin clastic sediments. Second, there is the Kumluca Zone, composed of thrust-imbricated deep-water passive margin sediments of Late Triassic to Late Cretaceous age. Third, there is the Gödene Zone, composed of sheared ophiolitic rocks (commonly serpentinite), deep-sea sediments, and large masses of shallow-water limestone, together ranging in age from Late Triassic to Late Cretaceous. Fourth, further east, is the Kemer Zone, dominated by steeply-dipping slices of Paleozoic (Ordovician-Permian) sedimentary rocks overlain by Mesozoic shallowwater carbonates (Tahtalı Dağ; Fig. 13A). Finally, there is the coastal Tekirova Zone (Fig. 13A-B), dominated by the deeper levels of a Late Cretaceous ophiolite (Tekirova ophiolite), which, however, lacks extrusives (Juteau, 1970; Yilmaz, 1984).
The Kumluca Zone is interpreted as the deformed deep-water, southeasterly passive margin of the Bey Dağları carbonate platform to the west. Lithologies include Late Triassic turbiditic sandstones and pelagic Halobia-limestones, Jurassic-Early Cretaceous non-calcareous radiolarian sediments and silicified calciturbidites. The Gödene Zone is interpreted as relatively proximal oceanic crust, and both shallow- and deep-water sedimentary units. It includes Late Triassic subalkaline pillow basalts up to $1000 \mathrm{~m}$ thick (Juteau, 1970). These lavas are intermediate in composition between within platetype basalt and mid-ocean ridge-type basalt (Robertson and Waldron, 1990). The extrusives are locally interbedded with, and overlain by, coarse siliciclastic turbidites, and rare quartzose conglomerates of Late Triassic age, proving a near continental margin origin (Robertson and Woodcock, 1982). The associated shallow-water limestones are interpreted as carbonate build-ups constructed in rifted continental blocks located within a zone of proximal oceanic crust adjacent to the rifted margin. The Kemer Zone is viewed as one, or probably several, slivers of continental crust that were rifted from the larger Bey Dağları continental fragment in the Triassic. The pre-rift Ordovician to Carboniferous successions are interpreted as a part of the North African passive margin (Monod, 1977). The Tekirova Zone is interpreted as oceanic crust and mantle of late Cretaceous age formed within the southerly Neotethys oceanic basin. It represents the most westerly preserved body of a zone of Upper Cretaceous ophiolites, including the Troodos ophiolite, and ophiolites in southeastern Turkey and Syria (e.g., Hatay and Baer-Bassit). All of these ophiolites formed in the southerly Neotethyan oceanic basin, in contrast to other ophiolites generally to the north, including the ophiolites of the Lycian Nappes in the west (see below), and the Hoyran-Beyșehir (and Hadim) Nappes further east. These were derived from a Neotethyan oceanic basin to the north of the Tauride carbonate platform (Şengör and Yilmaz, 1981; Robertson and Dixon, 1984; Fig. 1). The exact tectonic affinities of the Tekirova ophiolite are unclear, mainly because extrusives (used for geochemical fingerprinting of tectonic setting) are not preserved. However, ductile shear fabrics within the plutonic rocks suggest formation in the vicinity of an oceanic transform fault (Reuber, 1984).

The southwestern area of the Antalya Complex was initially deformed in the Late Cretaceous by a combination of wrench faulting and thrusting that occurred within the Neotethyan ocean (Woodcock and Robertson, 1982). The Antalya Complex was then emplaced generally westward over the relatively autochthonous Bey Dağları carbonate platform (a microcontinent) in late Paleocene-early Eocene time (Poisson, 1977; Robertson and Woodcock, 1982). Westward thrusting associated with foreland basin development carried the allochthonous units still further westward in the late Miocene.

The southwest area of the Antalya Complex is restored as the southeasterly rifted passive margin of a large microcontinental unit within Neotethys (the Bey Dağları-Menderes microcontinent; Fig. 14A). This continental fragment rifted from North Africa in the Late Permian-Early Triassic (Marcoux, 1974, 1995), followed by genesis of oceanic crust in the easternmost Mediterranean area in MiddleLate Triassic time (Robertson and Woodcock, 1984; Yilmaz, 1984). The basement of the Bey Dağları carbonate platform (the microcontinent in the west) is not exposed, but synrift and prerift units of preLate Triassic age are exposed along the eastern limb of the Isparta Angle (Gutnic et al., 1979; Waldron, 1984, e.g., Sutçular unit, Fig. 13). The exposed Bey Dağları succession in the southwest Antalya Complex area is dominated by Jurassic-Early Cretaceous shallowwater carbonates, overlain by Late Cretaceous-Paleogene pelagic carbonates (Poisson, 1977). The transition to deeper water carbonates is locally associated with sedimentary breccias (Robertson, 1993), indicative of a possible control by coeval extensional faulting. Widespread shallow-water carbonate deposition ended in the Cenomanian, followed by onset of pelagic carbonate deposition in the Turonian, 


\section{A}

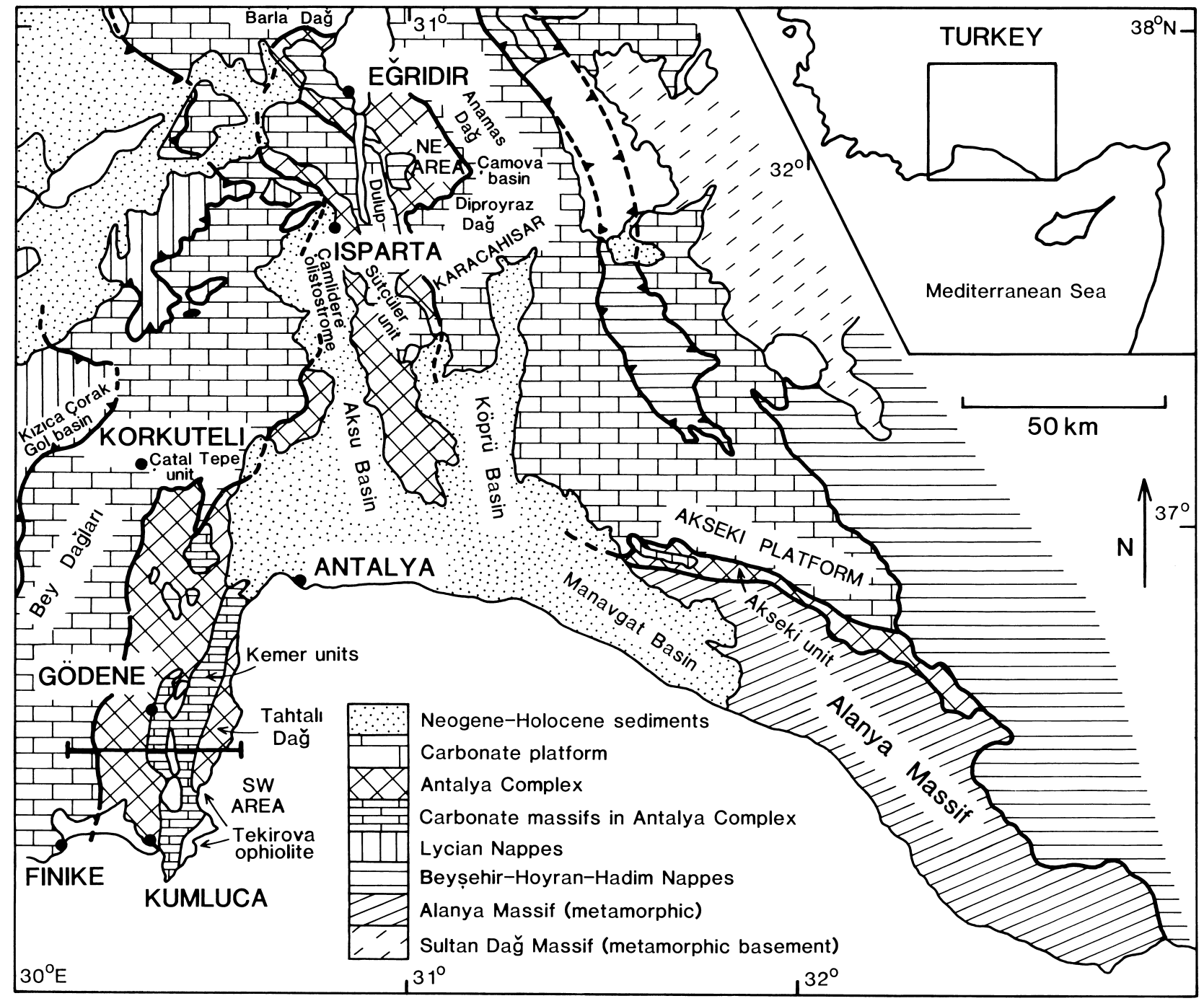

B
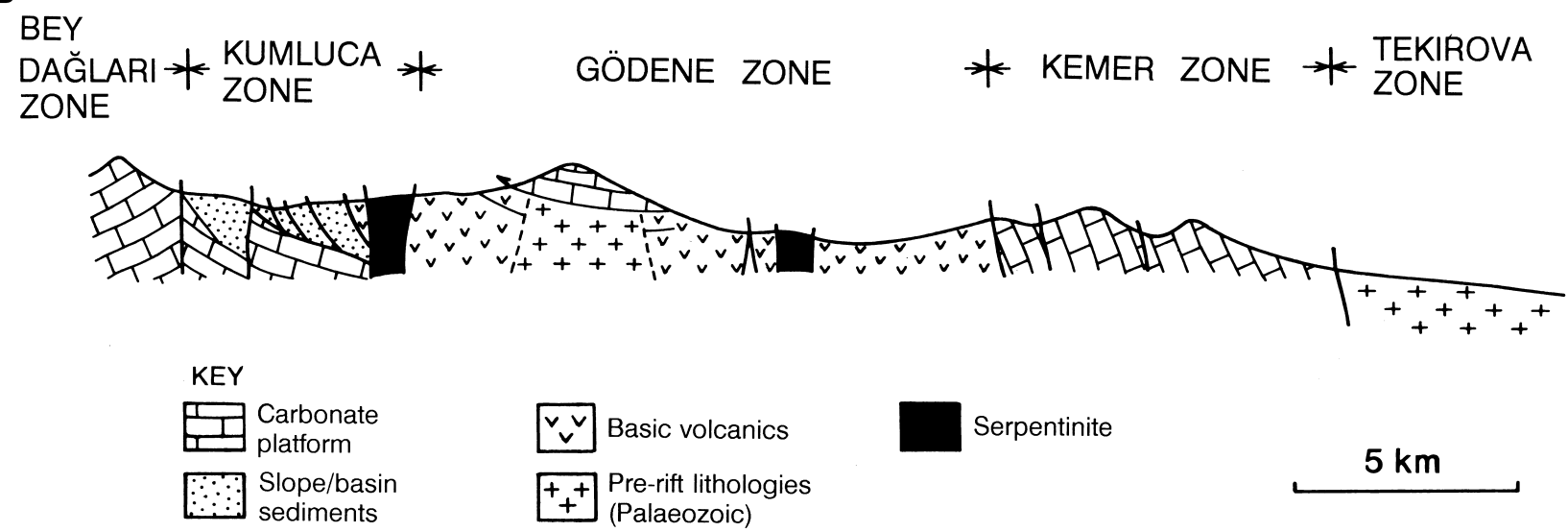

Serpentinite

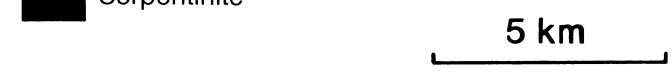

Figure 13. Antalya Complex of southwestern Turkey. A. Outline tectonic map of the Antalya area, showing particularly the large extent of relatively autochthonous Mesozoic carbonate platforms (e.g., Bey Dağları) and the Mesozoic Antalya Complex. Other units highlighted in the text are the Lycian Nappes, the Akseki Platform, and the Alanya Massif (modified after Robertson and Woodcock, 1984). Note: internal structure of the Antalya Complex is not differentiated. B. Cross section of the Antalya Complex. This is interpreted as a transition from a carbonate platform in the west, across a continent-ocean transition zone, marked by ophiolitic rocks and carbonate build-ups on rifted blocks of Palaeozoic crust. The Antalya Complex (southwest area) was tectonically emplaced in the latest Cretaceous-early Tertiary by a combination of westward thrusting and strike-slip. 


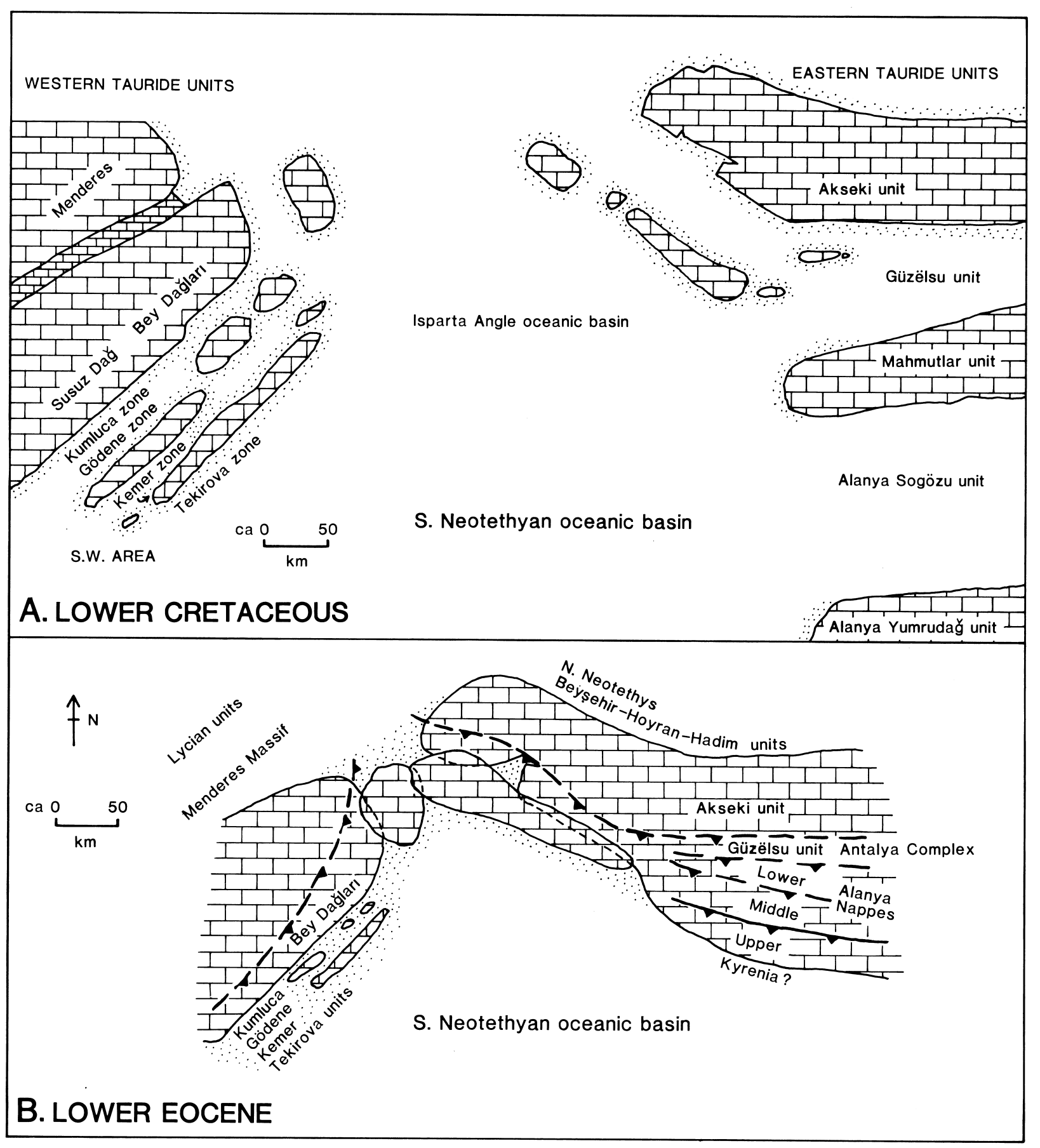

Figure 14. Reconstruction of the paleogeography and tectonic setting of the Antalya complex, southwestern Turkey in Early Cretaceous time. A. Lower Cretaceous. Large carbonate platforms were built on continental fragments rifted from Gondwana in the Triassic. In addition, a number of smaller satellite platforms existed. The reconstruction is based on unraveling the various tectonic units (Robertson, 1993), but cannot be accurate in view of uncertainties, such as the width of oceanic segments, size and shape of platforms, and so on. The diagram takes account of Neogene paleomagnetic rotations, as explained in the text. Paleolatitudes are those inferred by Dercourt et al. (1992) for the Taurus carbonate platform at these times. Modified after Robertson (1993). B. Lower Eocene. Units on either side of the Isparta Angle oceanic basin have collided, resulting in thrusting both westward onto the eastern margin and eastward onto the westward margin. The Neotethys still remained open to the south.

continuing until the early Paleocene when final emplacement of the allochthonous units (the Antalya Complex) took place (Poisson, 1977; Poisson, 1984; Robertson, 1993).

In summary, the Antalya Complex and related carbonate platform units record northerly areas of the southern Neotethyan oceanic ba$\sin$. The oceanic basin opened in the Middle-Late Triassic to form a mosaic of carbonate platforms and basins (Fig. 14A), followed by genesis of additional oceanic crust in the Late Cretaceous, possibly in an above-subduction zone setting (see later). Closure, probably associated with regional northward subduction, began in the Late Cretaceous (Maastrichtian) and persisted into early Tertiary time, resulting in collision and amalgamation of platform units (Fig. 14B). Any re- 
maining oceanic crust within the Isparta Angle area was eliminated by early Paleocene time, by collision of microcontinental units to the west and east, whereas the southerly Neotethys still remained open to the south (Fig. 14B).

\section{Onshore Southwest Turkey: Mesozoic Carbonate Platform and Nappes}

Coastal areas west of the Isparta Angle (north of the Anaximander Mountains, Fig. 7) are dominated by a Mesozoic carbonate platform, the Susuz Dağ, which is a southward extension of the regional Bey Dağlar1-Menderes microcontinental unit (Poisson, 1977; Fig. 7). In the west, the Susuz Dağ is overlain by a Miocene, mainly terrigenous clastic succession (Kaș basin; Fig. 7), interpreted as a foreland basin related to regional overthrusting of the Lycian Nappes from the northwest in the mid-late Miocene (Hayward, 1984). In general, the Lycian Nappes are a composite unit dominated by ophiolites, accretionary prism-type volcanic-sedimentary units, and sedimentary thrust sheets of Late Permian to Late Cretaceous age (De Graciansky, 1966; Poisson, 1977; 1984; Okay, 1990; Collins and Robertson, 1997; Robertson et al., 1996).

The volcanic-sedimentary unit includes tectonic mélange and disrupted shallow-water carbonates. The Lycian Nappes are restored as a passive margin and oceanic crust that originated to the north and northwest of the Menderes Massif (Fig. 7). The Menderes Massif is interpreted to be part of a microcontinental fragment (Menderes-Bey Dağları unit) within the Neotethyan ocean (Şengör and Yilmaz, 1981; Robertson and Dixon, 1984). The Lycian Nappes thus provide critical evidence of a more northerly Neotethyan oceanic basin $>500$ $\mathrm{km}$ further north than Neotethys in the easternmost Mediterranean.

In summary, the field evidence from southwestern Turkey shows that two separate Neotethyan oceanic basins developed in this region (southerly and northerly), with Antalya Complex representing remnants of the northern margin of the southern Neotethyan oceanic basin, whereas the Lycian Nappes are remnants of the northern oceanic basin and its southern margin.

\section{SEGMENT 2: LEVANT BASIN-ERATOSTHENES SEAMOUNT-CENTRAL CYPRUS-SOUTHERN TURKEY}

The next section will discuss the segment farther east that extends from the Levantine Basin, across the Eratosthenes Seamount, central Cyprus and the Cilicia Basin to southern Turkey (Fig. 5). The history of research concerning the Eratosthenes Seamount and adjacent units is summarized in Table 1. The term "Seamount" has caused some confusion, because to many a seamount is synonymous with a volcanic edifice, whereas drilling during Leg 160 revealed the Eratosthenes Seamount to be a Cretaceous-Miocene carbonate succession, underlain by crust of as yet unconfirmed character (Fig. 15). However, the term Eratosthenes Seamount is retained here for historical reasons. The Seamount is a key component of the collisional history of the Eastern Mediterranean (Ben Avraham and Nur, 1982, 1986; Robertson, 1990; Kempler, 1994, Chap. 53, this volume; Rotstein and Ben-Avraham, 1985).

\section{Eratosthenes Seamount}

The results of drilling during Leg 160 are synthesized within a local context in comparison papers (Robertson, Chap. 51, this volume; Mart and Robertson, Chap. 52, this volume), and related site survey data are summarized in the Initial Results volume (Emeis, Robertson, Richter, et al., 1996). Further background information is to be found in Limonov et al. (1994), Krashenninikov et al. (1994), Robertson et al., 1994; Kempler (1994, 1995a, Chap. 53, this volume).
The Eratosthenes Seamount is interpreted as a continental fragment with igneous intrusions or extrusions at depth, which was rifted from the African margin probably in the Triassic (Ben-Avraham et al., 1976; Kempler, 1994, Chap. 53, this volume). A shallow-water carbonate platform was later developed on this fragment, similar to many such units now exposed in southern Turkey (e.g., in the Antalya Complex; see above). Pre-Triassic continental "basement" is overlain by Mesozoic platform carbonates in the Taurus Mountains of southern Turkey (discussed earlier). Only part of an inferred carbonate platform, of Early Cretaceous age, was reached by drilling at Site 967 during Leg 160. In common with the Levant, this shallow-water carbonate platform was submerged in the Late Cretaceous-early Tertiary, ushering in pelagic carbonate accumulation. The most likely causes of observed depositional hiatuses (Flecker et al., Chap. 40, this volume), especially between Maastrichtian and middle Eocene, is tectonic instability combined with current erosion, affecting an isolated, submerged Eratosthenes carbonate platform. During or before the early Miocene the Eratosthenes Seamount was tectonically uplifted by $\sim 1 \mathrm{~km}$, allowing colonization by Miocene reefs. The cause of this uplift is problematic, but possibly relates to regional compression that accompanied onset of the present phase of northward subduction beneath Cyprus, during the Miocene onward. During the late Miocene, the Mediterranean sea-level fell and the Eratosthenes Seamount was exposed to meteoric water diagenesis and localized soil formation. When the sea flooded back at the beginning of the Pliocene, the Seamount subsided to bathyal depths. This subsidence was accompanied by formation of matrix-supported breccias, which are inferred to have been shed from active fault scarps. The main cause of the subsidence and faulting is seen as flexural loading of the seamount as it migrated north toward the Cyprus trench. Upon entering the trench, extension switched to compression and the seamount was loaded and collapsed at a rapid rate during late Pliocene-Pleistocene time. This subsidence history was accompanied by corresponding uplift of southern Cyprus (see below). The results of the drilling are synthesized in a companion paper (Robertson, Chap. 51, this volume).

One question is to what extent was the Eratosthenes Seamount thrust northward beneath Cyprus, or moved northeastward, subparallel to the present convergence direction of the African and Eurasian plates in this region (Fig. 6)? Reconstructions of the relative motion of the African and Eurasian plates based on Atlantic magnetic anomaly data, imply near-orthogonal movement for the last 10 m.y. (Livermore and Smith, 1984). Limited seismic refraction data suggest the existence of a slab dipping northwestward beneath Cyprus (Jackson and McKenzie, 1989; Ambreseys and Adams, 1993), implying that subduction is now toward the northeast. Global Positioning System (GPS) data confirm that southern Turkey is now escaping westward toward the Aegean (Töksoz et al., 1995; Smith et al., 1994; Reilinger et al., 1997), again consistent with northeastward subduction. Current studies of microseismicity onshore and offshore in southeastern $\mathrm{Cy}$ prus are expected to shed light on current plate displacement adjacent to the active margin south of Cyprus (J. Makris, pers. comm., 1996).

\section{Southern Cyprus}

The southern part of Cyprus (Fig. 9) is dominated by the Late Cretaceous Troodos ophiolite, Late Cretaceous mélange (i.e., "basement units"), and a sedimentary cover. The main features are summarized below, from south to north, as follows:

\section{Southerly Cover Sediments}

The southern cliffs of the Akrotiri Peninsula, nearest to the ODP drill sites, expose a flight of uplifted Pleistocene marine terraces, associated with local aeolianites (Poole, 1992; Poole and Robertson, 1992). The Pleistocene deposits are unconformably underlain by late Pliocene shallow-marine carbonates, rich in oncolites (calcareous al- 
Table 1. Summary of the history of research concerning the Eratosthenes Seamount.

\begin{tabular}{|c|c|c|}
\hline Authors & Key Observations & Comments \\
\hline $\begin{array}{l}\text { Leg } 160 \text { studies: } \\
\text { Robertson, Emeis, Richter, et al. } \\
\quad \text { (1996) and this volume }\end{array}$ & $\begin{array}{l}\text { Pliocene-Quaternary deep-sea muds underlain by shallow-water Miocene } \\
\text { limestones and then by upper Eocene and Upper Cretaceous pelagic limestones; } \\
\text { shallow-water at base; major depositional hiatuses; breccias indicate early } \\
\text { Pliocene break up and subsidence. }\end{array}$ & $\begin{array}{l}\text { Collapse of seamount to }>1800 \mathrm{~m} \text { coeval } \\
\text { with rapid uplift of southern Cyprus in late } \\
\text { Pliocene-early Pleistocene. }\end{array}$ \\
\hline $\begin{array}{l}\text { Limonov et al. (1994); Robertson } \\
\text { et al. (1995a; TTR-3) }\end{array}$ & $\begin{array}{l}\text { Seismic data indicate break-up of seamount by down-to-north normal faulting; } \\
\text { seamount down-flexed and thrust beneath Cyprus along active margin; also } \\
\text { compression-related subsidence along southern margin. }\end{array}$ & $\begin{array}{l}\text { First clear imaging of Cyprus "trench" and } \\
\text { upper part of down-going slab. }\end{array}$ \\
\hline Krashenninikov et al. (1994) & $\begin{array}{l}\text { Suggested Eratosthenes down faulted and thrust beneath Cyprus; dredged granite, } \\
\text { basalt; ?Cenomanian limestone and ?Tortonian-Quaternary pelagic carbonate. }\end{array}$ & $\begin{array}{l}\text { No evidence that granite and basalt are in } \\
\text { situ. Dredged coral probably Miocene not } \\
\text { Cenomanian. }\end{array}$ \\
\hline Kempler (1994) & $\begin{array}{l}\text { Eratosthenes as a quadrilateral graben surrounded by steep faults to produce a } \\
\text { "moat"; originated as a pre-Messinian high of African origin. }\end{array}$ & $\begin{array}{l}\text { High-angle faults and related "moat" concept } \\
\text { not supported by later evidence. }\end{array}$ \\
\hline Clube and Robertson (1986) & $\begin{array}{l}\text { Relate uplift of Cyprus to underthrusting of the Eratosthenes carbonate platform } \\
\text { or (more northerly) equivalent. }\end{array}$ & Cyprus uplift caused by collision. \\
\hline Sonnenfeld and Finetti (1985) & $\begin{array}{l}\text { Seismic data suggest that evaporites are absent from west of Eratosthenes } \\
\text { Seamount. }\end{array}$ & Confirmation of Messinian edifice. \\
\hline $\begin{array}{l}\text { Robertson (1990); McCallum and } \\
\text { Robertson (1990); Poole and } \\
\text { Robertson (1992) }\end{array}$ & $\begin{array}{l}\text { Synthesis of the Pliocene-Quaternary sedimentary cover of Troodos in terms of } \\
\text { collision-related tectonic uplift of southern Cyprus. }\end{array}$ & $\begin{array}{l}\text { Confirming dominant role of tectonics above } \\
\text { north-dipping subduction zone. }\end{array}$ \\
\hline Eaton and Robertson (1993) & $\begin{array}{l}\text { Deformation in southern Cyprus in early Miocene related to underthrusting, } \\
\text { possibly initial stages of northward subduction beneath southern Cyprus. }\end{array}$ & $\begin{array}{l}\text { Evidence of southward migration of } \\
\text { subduction front. }\end{array}$ \\
\hline $\begin{array}{l}\text { Kempler and Ben-Avraham } \\
\text { (1987) }\end{array}$ & Eratosthenes Seamount suggested to be a continental fragment rifted from Africa. & Eratosthenes part of African Plate. \\
\hline Garfunkel and Derin (1984) & $\begin{array}{l}\text { Available data suggest Levant margin rifted in the Triassic, orthogonally and not } \\
\text { by transform rifting. }\end{array}$ & $\begin{array}{l}\text { Eastern Mediterranean Tethys is oceanic } \\
\text { since the Triassic. }\end{array}$ \\
\hline Makris et al. (1983) & $\begin{array}{l}\text { Seismic refraction data suggest that both Eratosthenes and Cyprus are underlain } \\
\text { by continental crust. }\end{array}$ & $\begin{array}{l}\text { However, recently accepted to be on different } \\
\text { plates. }\end{array}$ \\
\hline Robertson and Woodcock (1980) & $\begin{array}{l}\text { Eastern Mediterranean Sea seen a relict of Tethys ocean; Levant possibly rifted } \\
\text { from Southern Turkey (Antalya) in Triassic. }\end{array}$ & $\begin{array}{l}\text { Eastern Mediterranean oceanic since the } \\
\text { Triassic. }\end{array}$ \\
\hline Montadert, et al. (1978) & $\begin{array}{l}\text { Available seismic data suggest the Eratosthenes platform not covered by } \\
\text { Messinian evaporite. }\end{array}$ & $\begin{array}{l}\text { Eratosthenes as a raised edifice in the } \\
\text { Messinian? }\end{array}$ \\
\hline Robertson (1978) & $\begin{array}{l}\text { Initial synthesis of tectonic uplift of the Troodos ophiolite since the Upper } \\
\text { Cretaceous; driving force serpentinite diapirism and tectonic collision. }\end{array}$ & $\begin{array}{l}\text { Rapid uplift of southern Cyprus in Plio- } \\
\text { Pleistocene. }\end{array}$ \\
\hline Woodside (1977) & $\begin{array}{l}\text { Single channel seismic survey of the Eratosthenes platform reveals reflective unit } \\
\text { below relatively transported unit; seamount is faulted; sediment-filled basin to } \\
\text { north. }\end{array}$ & $\begin{array}{l}\text { Subduction trench to the north visible with } \\
\text { benefit of hindsight. }\end{array}$ \\
\hline Ben-Avraham et al. (1976) & $\begin{array}{l}\text { Eratosthenes is a large deep-seated structure, large magnetized feature at depth } \\
\text { larger than, and displaced relative to, the bathymetric high; paleomagnetic pole } \\
\text { at } \sim 27^{\circ} \mathrm{N} \text {. }\end{array}$ & $\begin{array}{l}\text { Basic igneous material at depth; platform } \\
\text { evolved with Africa. }\end{array}$ \\
\hline Finetti and Morelli (1973) & $\begin{array}{l}\text { Eratosthenes platform is a major edifice with Tertiary or Mesozoic reflectors } \\
\text { dipping beneath the inferred base Messinian. }\end{array}$ & Eratosthenes emergent during Messinian? \\
\hline Giermann (1969) & $\begin{array}{l}\text { Identified major north-dipping fault to north of Eratosthenes Seamount } \\
\text { "Giermann Fault". }\end{array}$ & $\begin{array}{l}\text { This fault now seen as effective trace of } \\
\text { downgoing Eratosthenes slab. }\end{array}$ \\
\hline Gass and Masson-Smith (1963) & $\begin{array}{l}\text { Cyprus ophiolite uplift driven by underthrusting of the continental margin of } \\
\text { North Africa. }\end{array}$ & $\begin{array}{l}\text { Far-sighted inference of continental collision } \\
\text { as cause of Cyprus uplift. }\end{array}$ \\
\hline
\end{tabular}

Note: See text for explanation.

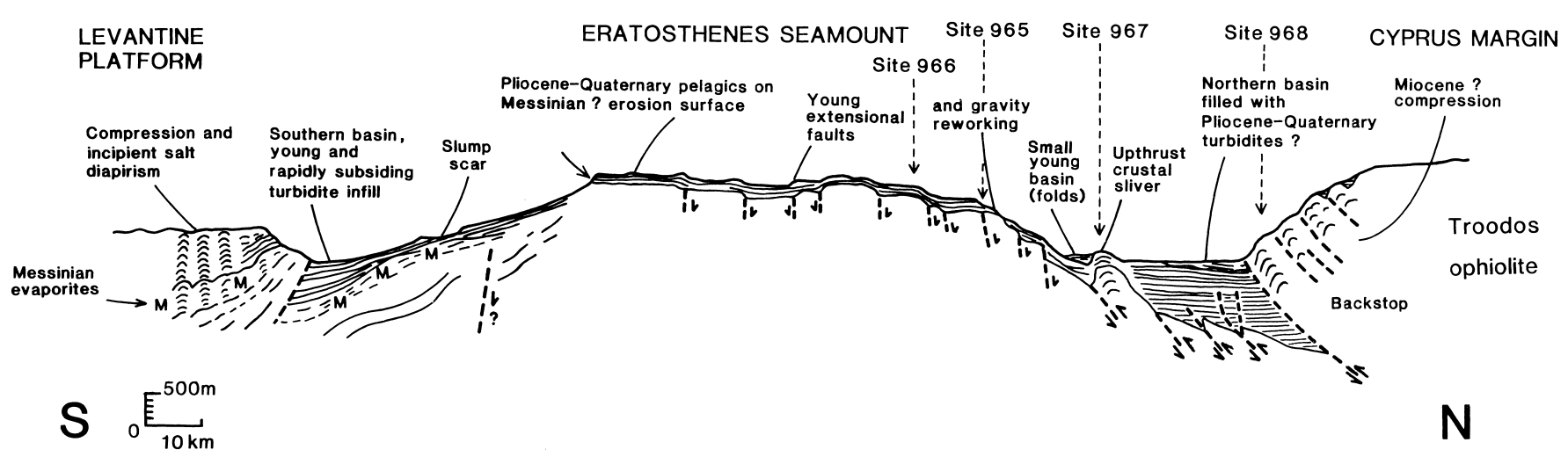

Figure 15. Sketch of the main features of the Eratosthenes Seamount, as determined during the site survey cruise for Leg 160 (modified after Limonov et al., 1994; Robertson et al., 1994, 1995b). Only relatively shallow structures can be recognized on this profile, although some deeper structures are visible on old multichannel seismic lines. For details, see Emeis, Robertson, Richter, et al. (1996). Location of seismic line (line 120) shown on Figure 7. 
gal structures), and pass downward into marine calcareous marls with planktonic foraminifers. These marls unconformably overlie thin Messinian facies composed of gypsum that is fragmented into blocks and angular clasts (some of which may be solution-collapse features), directly overlain by Pliocene marls. The oldest unit locally exposed at the foot of the southern Akrotiri cliffs is folded red ribbon radiolarites, correlated with the Mesozoic Mamonia Complex in west and southwest Cyprus (Morel, 1960). In the northern part of the Akrotiri Peninsula, Miocene carbonates of the Pakhna Formation show evidence of northward paleoslopes and derivation of bioclastic sediment from the south (Eaton and Robertson, 1993). During the late Miocene the Akrotiri Peninsula formed a topographic high that was colonized by reefs. This high can be traced eastward offshore on shallow seismic profiles as a west-northwest- to east-southeast-trending lineament (McCallum et al., 1993, Fig. 9). Formation of the Akrotiri high is attributed to compression and uplift during the Miocene.

The Akrotiri Peninsula is bordered to the north by the southern foothills of an ophiolitic massif within the Limassol Forest (Fig. 9). Pleistocene alluvial sediments in this area document transport of large volumes of coarse clastic sediment across a narrow coastal plain (Poole, 1992; Poole and Robertson, Chap. 43, this volume). The Kouris River west of the Akrotiri Peninsula drains the most elevated and deeply eroded parts of the Troodos ophiolite and was the main conduit for sediment supply offshore into a deep basin between $\mathrm{Cy}$ prus and the Eratosthenes Seamount (Northern basin; Fig. 15).

The Pleistocene clastic sediments are unconformably underlain by Pliocene open-marine calcareous muds. A sharp upward transition over several meters is seen, from marine muds to channelized ophiolite-derived conglomerates at Zyyi. This dramatic change in facies is interpreted as the result of rapid uplift of the Troodos Massif and Limassol Forest areas to the north (Fig. 16). At Khirokitia (Fig. 9), a deep channel was cut into the underlying Miocene Pakhna Formation and infilled by calcareous muds and channelized conglomerates, dated as late Pliocene, based on calcareous nannofossils (Houghton et al., 1990). The incision is interpreted as the result of early strong uplift that was possibly coeval with eustatic sea level fall. Shallow channels in the Miocene succession further west (near Amathus, Fig. 9), infilled with bioclastic carbonate, are also dated as late Pliocene.

The Pliocene succession is underlain by Messinian evaporites within several tectonically controlled small basins (termed subbasins). These are the Maroni sub-basin in the east and the Khalassa sub-basin in the west (Eaton and Robertson, 1993; Orszag-Sperber et al., 1989; Robertson et al., 1995a; Figs. 9, 16). The Messinian evaporites of southern Cyprus are cut by numerous high-angle extensional faults that are not observed in the overlying Pliocene succession.

The Messinian evaporites are underlain by Miocene pelagic carbonates (Pakhna Formation). In most areas of southern Cyprus, the Pakhna Formation disconformably overlies pelagic carbonates of Maastrichtian to Oligocene age (Lefkara Formation). However, south of the Limassol Forest ophiolitic terrain, the Lefkara Formation is largely absent and Tortonian shallow-marine limestones (Koronia Member) unconformably overlie basement units (Moni mélange; see below; Figs. 9, 16). Reed (1993) located several outcrops where the lowest unconformably overlying Pakhna Formation sediments are of late Langhian to late Serravallian age. The cause of this localized unconformity was a pulse of north-south compression, dating from the early Miocene (or slightly earlier), that gave rise to a west-northwestto east-southeast-trending lineament, marked by folding and southward thrusting in the west (Yerasa Fold and Thrust belt; Morel, 1960; Robertson et al., 1991b; Eaton and Robertson, 1993, Fig. 9). In the northwest, the deformation is marked by southward thrusting and folding of the southern margin of the Limassol Forest ophiolite over the Paleogene sedimentary succession to the south. Further southeast, the lineament is defined by large, tight upright folds, which might have formed above blind thrusts. The lineament can be traced eastward offshore on shallow seismic profiles (McCallum et al., 1993;
Gass et al., 1994, Fig. 9). Localization of the deformation near the southern margin of the Limassol Forest ophiolite could reflect reactivation of zones of structural weakness dating from the Late Cretaceous. Away from the deformed lineament a more complete Miocene succession is present within the Pakhna Formation. This includes patch reefs of early Miocene age (Terra Member of the Pakhna Formation), exposed in southeastern Cyprus (Follows, 1992; Follows et al., 1996).

Two possible explanations for the Yerasa lineament are: (1) Northward subduction beneath southern Cyprus was already in progress and the deformation resulted from collision of a topographic high (similar to the Eratosthenes Seamount) with the trench (Eaton, 1988); (2) The deformation relates to regional compression that accompanied the onset of northward subduction to the south of Cyprus (Eaton and Robertson, 1993). The compressional evidence is restricted to the central southern part of Cyprus and is certainly not a pervasive regional event. In option 2, convergence of the African and Eurasian plates was previously accommodated by subduction to the north of Cyprus. The zone of compression then "jumped" southward, marked by folding and thrusting in southern Cyprus, and tectonically induced uplift of the Eratosthenes Seamount. After subduction began, compression of southern Cyprus ended and the area was later transgressed by middle-late Miocene shallow-water carbonates.

A switch from compression to extension took place between early and late Miocene time in southern Cyprus. This extensional faulting could have accompanied a period of steady-state northward subduction beneath southern Cyprus, following initiation of subduction, but before initial collision of the Eratosthenes Seamount with the Cyprus active margin during Messinian?-early Pliocene time.

The Miocene Pakhna Formation is unconformably underlain by Paleogene pelagic carbonates of the Lefkara Formation. Biostratigraphic evidence for the timing of the downward transition from the Pakhna to the Lefkara Formation was reviewed by Reed (1993). More recently, T. Morse (pers. comm., 1996) confirmed that the Lefkara-Pakhna contact corresponds to the Oligocene-Miocene boundary, as in most previous studies.

The type section of the Lefkara Formation is to the east of the Limassol Forest (about $700 \mathrm{~m}$ thick near Lefkara; Fig. 9). It is dominated by pelagic chalks, ranging from Maastrichtian-Oligocene age according to Mantis (1970), following earlier Geological Survey work. The earliest unit, of inferred Maastrichtian age (Lower Lefkara Formation) infills broad hollows in the surface of the underlying Troodos ophiolite and adjacent mélange. The overlying unit (Middle Lefkara Formation) begins with a lower interval, dated by Mantis (1970) as late Paleocene-early Eocene in age. This unit contains extensive pelagic calciturbidites (Robertson, 1976), extensively replaced by chert (Robertson, 1978). There is then an upper "massive" unit, dated by Mantis as late Eocene in age, that is extensively bioturbated, but retains some pelagic calciturbidites, together with some evidence of slumping. Above this, the succession, dated as mainly Oligocene in age by Mantis (1970; Upper Lefkara Formation), is mainly composed of marly pelagic carbonates with little evidence of chert, redeposition, or slumping.

Recently, one succession of the Lefkara Formation in the west (near Perapedhi) was studied in detail for calcareous microfossils, benthic foraminifers, radiolarians, and diatoms (Krashenninikov and Kaleda, 1994). As a result, Mantis's (1970) biostratigraphy was revised. The basal pelagic carbonates (equivalent to the Lower Lefkara Formation) were reassigned to a much longer time interval, extending from upper Campanian, through Maastrichtian and Danian, to Paleocene time. Above this, the interval previously defined as the chertrich interval of the Middle Lefkara Formation, previously of late $\mathrm{Pa}$ leocene-early Eocene age, was shown to be of entirely early Eocene in age. Above this, the massive chert-free part of the Middle Lefkara Formation, regarded as late Eocene in age by Mantis (1970) was reassigned to a middle-late Eocene age. The Upper Lefkara Formation 


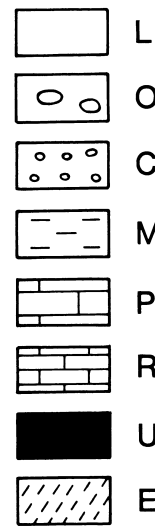

Land

Olistostromes/debris flows

Coarse ophiolite-derived clastics

Mudstone and siltstone

Pelagic carbonate

Reef limestones

Uplifted marine terraces

Evaporites

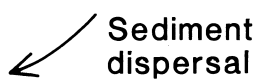

LOWER-MIDDLE MIOCENE

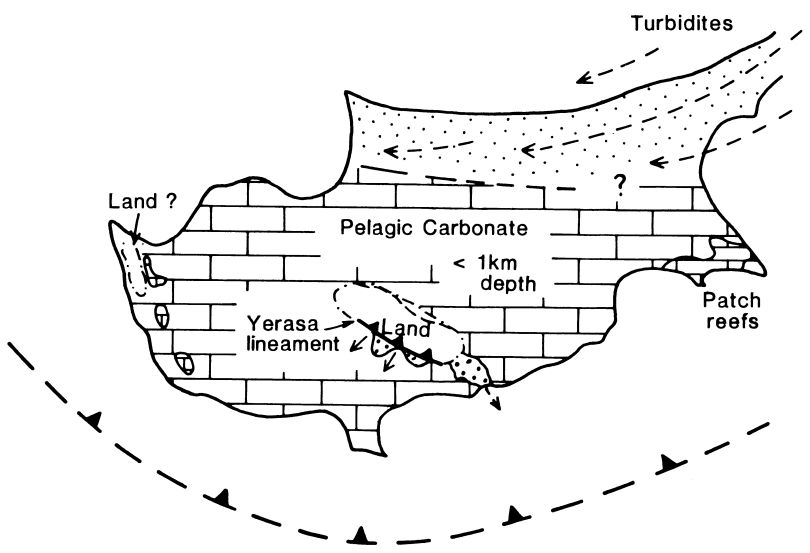

EARLY PLIOCENE

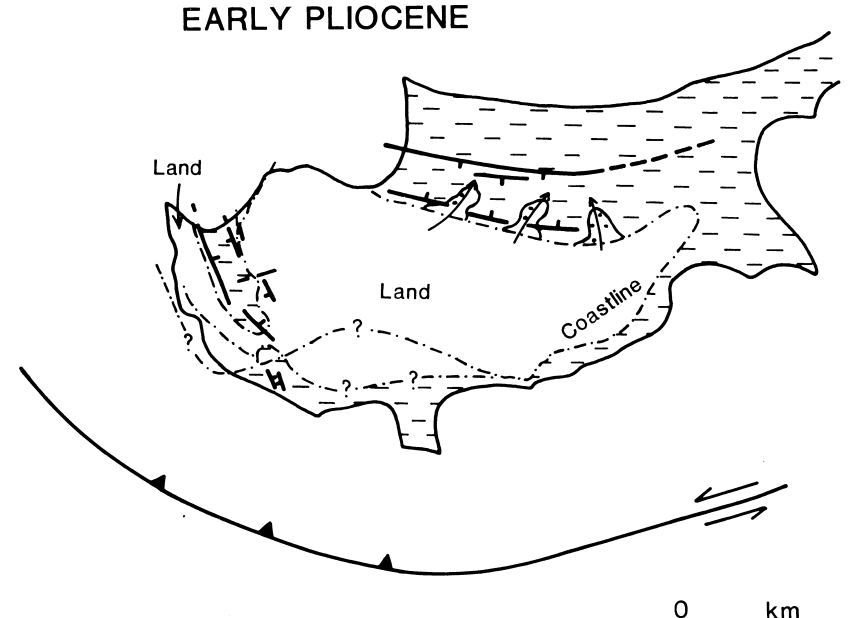

$0 \quad \mathrm{~km} \quad 50$
EOCENE

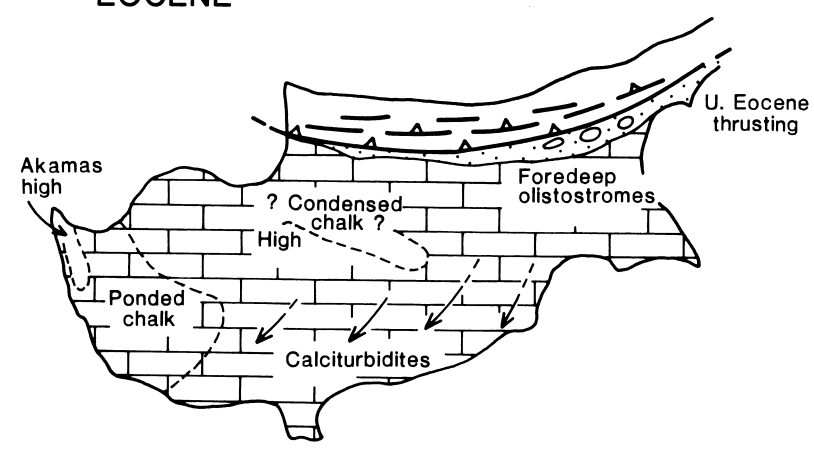

UPPER MIOCENE

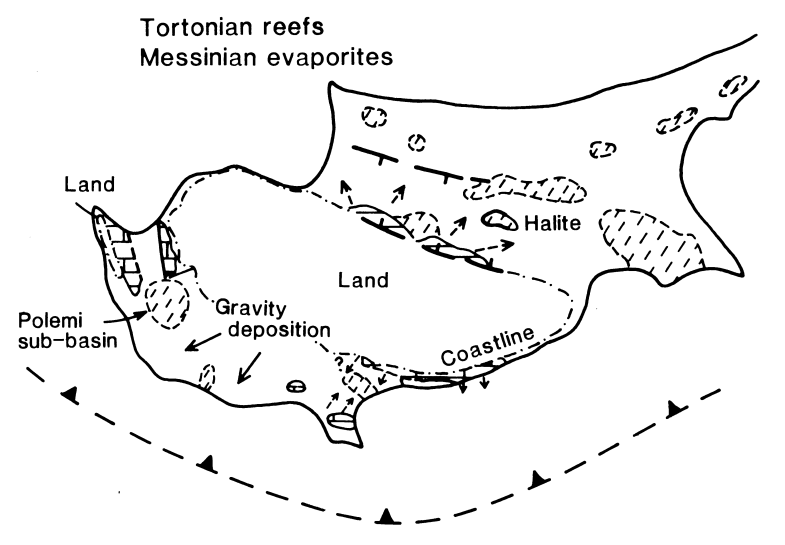

QUATERNARY

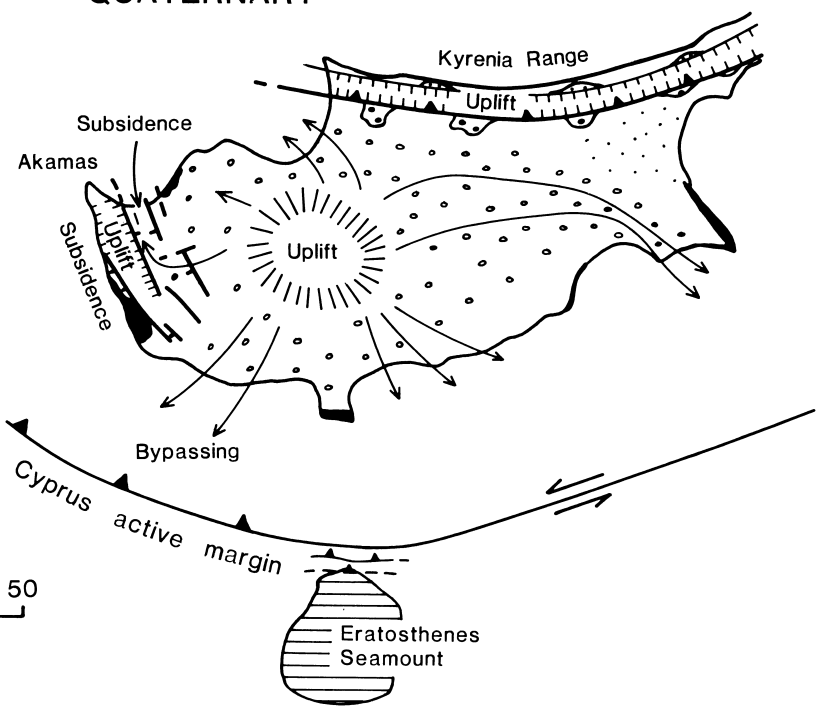

Figure 16. Paleogeographic sketches of the early Tertiary to Holocene evolution of Cyprus. See text for explanation. Modified after Robertson (1978).

of Mantis (1970) was subdivided into two new formations, the "Kilani Formation," of Oligocene age, and the "Arsos Formation," of Oligocene to early Miocene (Aquitanian) age.

The above proposed stratigraphic revisions pose problems. It is unclear if Krashenninikov and Kaleda (1994) are in fact radically changing the previously determined ages for specified parts of the succession, as opposed to relocating the boundaries between existing units of the Lefkara Formation. The Kilani and Arsos formations are not readily mappable units and serve little purpose. Also, the suggested age of the Arsos formation (extending up into the early Miocene) conflicts with studies of numerous sections indicating that the Pakhna Formation begins at the base of the Miocene, as noted earlier. The most important finding of the recent Russian work for regional correlation is that the chert-rich interval on Cyprus is restricted to the 
Ypresian-Lutetian, rather than extending as far down as the upper $\mathrm{Pa}$ leocene, as in Mantis's (1970) stratigraphy. This chert may reflect a time of high productivity within a surviving remnant of the southerly Neotethys. Also, the presence of the Danian was confirmed for the first time.

\section{Basement Units}

In southern Cyprus, the foothills of the Limassol Forest as far as the southeast coast of the island are characterized by the Moni mélange that underlies the Maastrichtian to Paleogene chalk succession (Robertson, 1977a; Fig. 9). The Moni mélange comprises blocks of Mesozoic lithologies, mainly similar to those of the Mamonia Complex in southwest Cyprus, including terrigenous sandstone turbidites, pelagic limestones, radiolarian cherts, and basic extrusives. There are also large blocks of quartzose sandstone of probable deltaic and slope facies, and variably sized blocks of radiolarian-rich siltstone and pelagic limestone with thin calciturbidites. At one locality, radiolarianrich sediment were recently dated as Cenomanian in age based on radiolarians (Urquart and Banner, 1994). The Mesozoic blocks of the Moni mélange are set in a matrix of volcanogenic clays of late Campanian age, based on radiolarians (Urquart and Banner, 1994) and calcareous nannoplankton (Morse, 1996). Similar clays form the local, in situ sedimentary cover of the Limassol Forest ophiolite north of the Moni mélange outcrop.

The Moni mélange includes large east-west-trending sheets of serpentinite. The lowest part of this ultramafic unit is composed of serpentinized harzburgite that is brecciated and fissured, with an infill of pink fine-grained carbonate. The middle part of the serpentinite sheet is mainly composed of fissured harzburgite, cut by rare rodingitized pegmatitic dikelets, again with fissures infilled with pink pelagic carbonate. The upper surface of this relatively coherent serpentinite sheet is associated with pockets of metalliferous oxide-sediment (umber). The highest part of the serpentinite sheet is mainly serpentinite-derived conglomerates (debris flows), which include clasts of gabbro, diabase, and chromite, in addition to common serpentinized harzburgite.

The serpentinite sheets within the Moni mélange are interpreted as having originally formed as part of the Upper Cretaceous oceanic fracture zone to the north (the South Troodos Transform Fault Zone; Fig. 9). Slices of transform fault material were emplaced by thrusting or transgression southward into the Moni mélange.

The exotic blocks of the Moni mélange are inferred to have been derived from a Mesozoic continental margin located to the south of Cyprus (to the east before paleorotation). Emplacement of the Moni mélange is attributed to sliding of blocks into the clay-rich sedimentary cover of a Upper Cretaceous ophiolite (Fig. 12A), either related to orthogonal subduction (Robertson, 1977a), or to strike-slip "docking" of an exotic terrain during paleorotation of the Cyprus microplate (Clube and Robertson, 1986). Recently, Gass et al. (1994) suggested that the Moni mélange was thrust northward over the ophiolite to the north. However, at a number of localities, such as, for instance, the Mangaleni umber pit, metalliferous sediments above the ophiolite (Perapedhi Formation) are depositionally overlain by debris flows marking the base of the Moni mélange with no evidence of significant thrust displacement.

Further north is the South Troodos Transform Fault Zone (MacLeod, 1990; Fig. 9). This is generally interpreted as a Upper Cretaceous fracture zone formed within the southerly Neotethyan oceanic basin, adjacent to the Troodos ophiolite (Simonian and Gass, 1978; Murton and Gass, 1986; Gass et al., 1994). Paleomagnetic evidence, and a recent revaluation of the field kinematic evidence, indicate that deformation along the transform was right-lateral (Morris et al., 1990; Robertson and Xenophontos, 1993; MacLeod and Murton, 1993). The transform fault zone extends at least as far south as the serpentinite lineaments within the Moni mélange, as described above. The transform zone comprises a highly fractured basement of ophiolitic rocks similar to the main Troodos ophiolite to the north. This basement is extensively sheared, brecciated, and cut by elongate east-west-trending screens of serpentinite. The basement is also intruded by distinctive high-level gabbros, silicic intrusives (plagiogranite) and ultramafics (wehrlites).

To the north of the South Troodos Transform Fault Zone is the main Troodos ophiolite (for a recent summaries see Robinson and Malpas, 1990; Gass, 1990; Robertson and Xenophontos, 1993). The Troodos formed in the Cenomanian-Turonian (92-90 Ma), based on $\mathrm{U}-\mathrm{Pb}$ ages of plagiogranites (Mukasa and Ludden, 1987). Geochemical evidence, especially the composition of unaltered volcanic glass, and analysis of "immobile" trace elements within the extrusives, has lead to wide acceptance of the concept that the ophiolite formed by spreading above a subduction zone, within the southerly Neotethyan oceanic basin (Pearce et al., 1984). Similar Upper Cretaceous ophiolites stretch as far east as Oman and the Himalayas and are interpreted to indicate formation related to regionally northward-dipping subduction (e.g., Moores et al., 1984). This interpretation, based mainly on geochemistry, is crucial as it means that these Upper Cretaceous ophiolites cannot have formed at mid-ocean-type spreading ridges, as suggested in some paleotectonic syntheses (e.g., Dercourt et al., 1986, 1992).

The outcrop pattern of the Troodos ophiolite shows that ultramafic rocks are restricted to a relatively small area in the vicinity of Mt. Olympos, whereas the outcrop of the erosionally resistant sheeted diabase is far greater (Fig. 9). For this reason, Pleistocene clastic sediments of the Mesaoria basin to the north are dominated by diabase and basalt (and some gabbro), but contain only subordinate ultramafic clasts (Poole and Robertson, 1992; Chap. 43, this volume). The exposure of ultramafics is attributed to large-scale diapiric protrusion of serpentinite from mantle rocks beneath (Moores and Vine, 1971). The uplift may have been triggered by the underthrusting of the Eratosthenes Seamount (Robertson, 1990).

The transition from Upper Cretaceous deep-water pillow lava to metalliferous and pelagic sediments (Perapedhi Formation) is depositional and unbroken (Robertson and Hudson, 1974). This contrasts strongly with the other southerly Neotethyan Upper Cretaceous ophiolites (e.g., Hatay and Oman), where emplacement onto the Arabian platform was followed by emergence, erosion, fluvial deposition, and then by shallow-marine transgression. This continuity of deep-water fine-grained sedimentation is a key piece of evidence that the Troodos ophiolite is not a nappe that was obducted onto North African continental crust in the Late Cretaceous, as in some interpretations (e.g., Ricou et al., 1984).

Seismic refraction data show that continental crust is now present beneath Cyprus (Makris et al., 1983), but how and when was this emplaced beneath the Troodos ophiolite? One possibility is that the Troodos was obducted onto a microcontinent within Neotethys in the Late Cretaceous (Murton, 1990). Another is that any continental crust beneath Cyprus is effectively an extension of the Eratosthenes Seamount, and was emplaced beneath Cyprus in Neogene-Holocene time. A new seismic refraction line has recently been run east-west along the northern flank of the Troodos ophiolite (A. Khan, pers. comm., 1996), and this may help to resolve these alternatives. It is assumed here that the Troodos ophiolite was not emplaced onto the North African continental margin in the Late Cretaceous. Accepting that thinned continental crust ( $\sim 25 \mathrm{~km}$ thick) is present beneath $\mathrm{Cy}-$ prus (Makris et al., 1983), it was probably emplaced there as a result of northward subduction and underplating of one, or several, continental fragments in Neogene present-day time.

\section{Northerly Cover Sediments}

To the north, the Troodos ophiolite disappears beneath a cover of Late Cretaceous to Holocene sediments, forming the Mesaoria basin 
beneath the Mesaoria Plain, located between the Troodos Massif and the Kyrenia Range to the north (Figs. 9, 16). The most southerly and stratigraphically highest of these cover sediments are remnants of originally extensive Pleistocene-Holocene ophiolite-derived conglomerates, locally preserved as channels cut into the Troodos ophiolite (Poole and Robertson, 1992).

The Neogene-Pleistocene uplift of the Troodos Massif is marked by development of a series of erosional surfaces that are well preserved on the northern flank of the Troodos, compared to the southern flank (Poole et al., 1990; Poole and Robertson, 1992). The probable reason is that in southern Cyprus extensive run-off took place into the open Mediterranean Sea, but into an inter-montane Mesaoria Basin to the north; this soon filled with coarse clastic sediment, inhibiting farther downcutting of source areas.

The surface of the Mesaoria Plain is covered by a veneer of mature conglomerates (Fanglomerate Group) derived from the Troodos ophiolite. Younger alluvial terraces are at progressively lower topographic levels, which is interpreted as the result of fluvial downcutting during dominant tectonically driven uplift (Poole and Robertson, 1992, Chap. 43, this volume). The Pleistocene fanglomerates are underlain by a fluvial unit, and then by a shallow-marine unit, both of which are interpreted to be deltaic complexes of late Pliocene-early Pleistocene age (McCallum, 1989; McCallum and Robertson, 1995). These units passed northward into a shallow-marine sea in which current-swept bioclastic carbonates accumulated (McCallum and Robertson, 1995). This sea lapped northward onto the slopes of the Kyrenia Range, before its strong uplift in the late Pliocene-Pleistocene (Fig. 16).

Borehole data indicate that the Pliocene is up to $950 \mathrm{~m}$ thick within the Mesaoria basin (McCallum and Robertson, 1990, 1995). The late Pliocene sediments are disconformably underlain by open marine muddy sediments of early to mid-Pliocene age. Channelized conglomerates (and some bioclastic carbonates) were fed northward into the Mesaoria sea from the Troodos ophiolite during this time, primarily under the influence of tectonic uplift, modified by glacioeustatic sea-level change (McCallum and Robertson, 1995). However, the southern margin of the Mesaoria basin was affected by downto-the-north extensional faulting in early Pliocene-late Miocene time. Gypsum accumulated in small-fault controlled basins during the Messinian (Robertson et al., 1995a), whereas Tortonian reefs developed on tilted fault blocks before this time (Follows and Robertson, 1990).

Little or no evidence of faulting is observed within the late Pliocene-Pleistocene sediments of the southern part of the Mesaoria Basin (McCallum and Robertson, 1990). The southern part of the Mesaoria basin is thus interpreted as a mid-Pliocene-late Miocene faulted extensional basin, possibly related to southward retreat ("rollback") of a subduction zone to the south (Fig. 16).

The northern part of the Mesaoria basin, adjacent to the Kyrenia Range, has a complex Neogene-Holocene tectonic history. Late Pliocene shallow-water carbonates show evidence of accumulation in an unstable basin, interpreted as a small flexural foredeep related to southward thrusting along a lineament, the Ovgos Fault (McCallum and Robertson, 1990, Figs. 9, 17). This thrusting relates to southward compression and early uplift of the Kyrenia Range. However, during late Miocene? to early Pliocene time the Ovgos Fault existed as a down-to-the-south extensional feature that separated the Pliocene Mesaoria basin from a relatively uplifted area to the north including Miocene terrigenous turbidites (Robertson and Woodcock, 1986).

\section{Kyrenia Range}

To the north of the Mesaoria Plain is the narrow, elongate Kyrenia Range that has a long and varied tectonic history (Figs. 17, 18). Its interpretation is critical to understanding of the evolution of Neotethys in the easternmost Mediterranean region.
The altitudes of Pleistocene terraces are interpreted to indicate that the central and western parts of the Kyrenia Range have undergone more uplift during the Pleistocene than the eastern part of the range. Also, some terraces are reported to be tectonically tilted (Dreghorn, 1978). To the south, localized Pleistocene deposits are underlain by open-marine muddy and calcareous sediments of early to midPliocene age. Their proximity to the Kyrenia Range confirms that no strong uplift occurred until the late Pliocene.

The Kyrenia Range was strongly uplifted in the late PliocenePleistocene, coeval with uplift of the Troodos Massif. Kyrenia Range units are locally reverse faulted and folded against Miocene and Pliocene sediments along the southern margin of the Range (Robertson and Woodcock, 1986; Fig. 17; see cross sections). Tilting of the Kyrenia Range stratigraphy to steep angles took place at this stage, particularly in the western and central parts of the Kyrenia Range that are dominated by competent Mesozoic carbonate rocks. Robertson and Woodcock (1986) suggested that the steepening of units was related to southward ramping over a rigid basement of Troodos-type ophiolitic rocks at depth to the south (Fig. 17, upper section). An alternative is that the steep dip results from transpression along the Kyrenia Range (Kempler, 1994). Unfortunately, insufficient field kinematic evidence currently exists to test these alternatives. In either scenario, the Kyrenia Range experienced compression during late Pliocene-Holocene time.

In the south, Pliocene fine-grained sediments are underlain by localized Messinian gypsum within small basins exposed along the southern margin of the Kyrenia Range. The gypsum is locally disrupted and deposited as coarse debris flows that are crudely channelized, suggestive of a tectonic (fault) control of deposition (A.H.F. Robertson, unpubl. data). The northern margin of the Mesaoria basin experienced tectonic instability in the late Miocene, but this was probably extensional, in common with the circum-Troodos area to the south.

The Mesozoic-early Tertiary core of the Kyrenia Range is overlain by Miocene turbidites, the Kithrea Flysch (Kithrea Group, Fig. 17), that is exposed on both flanks and locally within the Kyrenia Range. This evidence shows that the Kyrenia Range cannot have existed as a major elevated topographic lineament in the Miocene (Robertson and Woodcock, 1986). Paleocurrent evidence indicates derivation of the Kithrea turbidites mainly from the northeast, from the paleo-Seyhan River in the Adana area of southern Turkey (Weiler, 1965). The Kyrenia Range is assumed to have formed the southern part of a basinal area in late Oligocene-Miocene time that extended northward and eastward into southern Turkey.

Along the southeastern flank of the Kyrenia Range, late Miocene facies are much thicker to the south of the Kithrea Fault (Fig. 17) than to the north. This fault acted as part of a down-to-the-south extensional system during this time (Robertson and Woodcock, 1986), separating the depositional area into sub-basins, with the main depocenter being to the south.

The lower turbidites of the Kithrea Flysch, dated as late Oligocene (Baroz, 1979; Fig. 18), pass downward over a short interval (several meters) into shallow-marine sediments, then into non-marine facies fluvial conglomerates and minor lacustrine deposits also of early Oligocene age (Bellapais Formation; Fig. 18). Many of the clasts are exotic to the Kyrenia Range (e.g., abundant ophiolitic material), with clast imbrication indicating derivation from mainly the east and northeast, presumably from southern Turkey (Robertson and Woodcock, 1986). In the early Oligocene, the Kyrenia lineament is interpreted to have formed part of a landmass contiguous with southern Turkey. Alluvial fans, derived from terrains including ophiolites, were shed into the Kyrenia Range area, followed by rapid subsidence and onset of deep-water turbiditic deposition in latest Early Oligocene-early late Oligocene time. It is, therefore, possible that the marine Cilicia Basin to the north dates from late Oligocene-early Miocene time (see later). 


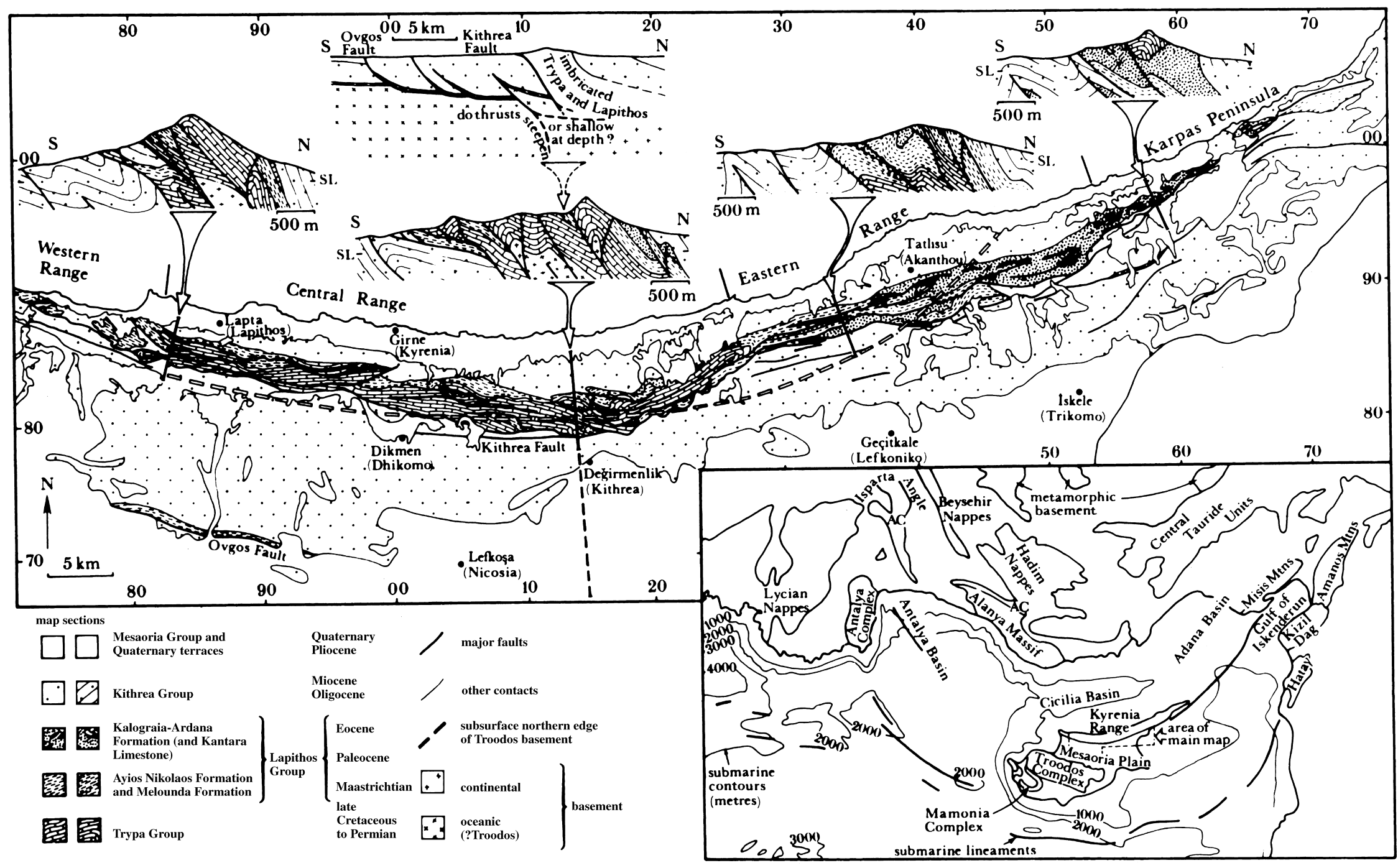

Figure 17. Outline geological map of the main part of the Kyrenia Range, with true-scale cross sections and inserted regional geological setting (from Robertson and Woodcock, 1986). Local map grid is indicated. Structuring took place in stages from late Cretaceous to Holocene, but the most important event (southward thrusting) took place in the late Eocene; see Figure 18. 

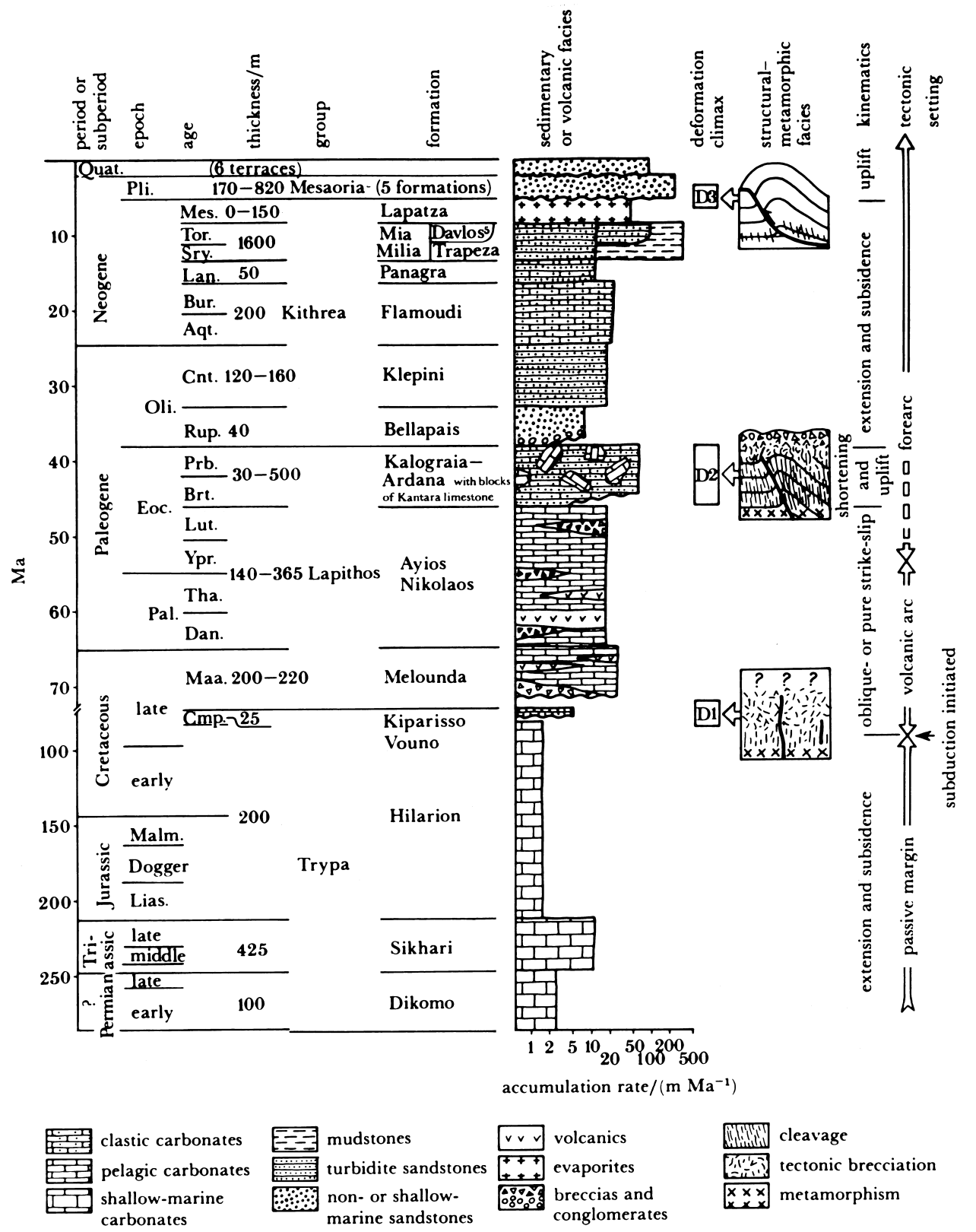

Figure 18. Summary of tectonostratigraphy of the Kyrenia Range, northern Cyprus (from Robertson and Woodcock, 1986). Structuring took place in three stages (D1-D3). A switch from a passive margin to an active margin with thrusting and strike-slip took place in the late Cretaceous.

The Kithrea Flysch overlies and seals an important east-westtrending thrust lineament within the Kyrenia Range, that is dated as late Eocene, based on the age of associated syntectonic "olistostromes" of late Eocene age (Kallograi-Ardana unit; Ducloz, 1972, Fig. 18). This latter unit is best developed in the eastern part of the Kyrenia Range and includes large detached blocks of Permian limestone and heterogeneous debris flows. Most thrusts and related folds of this age face southward, but some face locally northward (Robertson and Woodcock, 1986), consistent with a transpressional component of deformation. Tertiary sediments and volcanics were locally transformed to low-grade schists, associated with thrusting. This thrusting is seen as the most southerly manifestation of dominantly southward tectonic transport within the Taurus Mountains to the north, including final emplacement of the Alanya Massif in early to middle Eocene time (Okay and Özgül, 1984; Fig. 6). Kempler and
Garfunkel (1994) suggested that the Kyrenia Range was emplaced by dominantly left-lateral strike-slip. However, in the field evidence of dominantly southward overthrusting is clearly observed. The Kallograi-Ardana "olistostromes" were interpreted as having developed in a small flexural foreland basin in advance of the Kyrenia Range thrust sheets (Robertson and Woodcock, 1986). The debris flows could equally be interpreted as a trench-type deposits related to northward subduction of any remaining (Troodos-type) oceanic crust to the south. The existence of deep-focus earthquakes beneath the Kyrenia Range suggests the presence of a relict slab at depth that could have been emplaced during late Eocene northward subduction (Kempler and Garfunkel, 1991, 1994). From Maastrichtian to late Paleocene, the Kyrenia lineament experienced deep-water pelagic carbonate deposition (Malounda and Ayios Nikolaos Formations; Figs. 17, 18), interspersed with bimodal basic-acidic volcanism. Analysis of ba- 
salts including "immobile" trace elements revealed that the volcanism is of within-plate type, with no identifiable subduction component (Robertson and Woodcock, 1986). This is important as it opposes the widely held view, based on only major-element data (unreliable because of element mobility), that the volcanics represent a subduction-related volcanic arc unit (Baroz, 1980). During the Maastrichtian-early Tertiary, the Kyrenia Range was located in a deep-water basinal setting. Robertson and Woodcock (1986) suggested that the volcanics were erupted in an extensional, or transtensional setting, that was possibly related to paleorotation of the Troodos microplate, which continued to lower Eocene time (Clube and Robertson, 1986). Kempler and Garfunkel (1994) suggested that the volcanics might be correlated with Paleocene-Eocene basic volcanic rocks in southeastern Turkey ("Maden Formation"). The Kyrenia volcanics are indeed somewhat similar to middle Eocene volcanics in southeastern Turkey (Karadere Unit; Aktaș, 1985; Aktaș and Robertson, 1984, 1990; see later discussion), but the Kyrenia extrusive rocks were erupted over a much longer time interval and lack a distinctive trace-element subduction imprint, as exhibited by both Upper Cretaceous and Eocene volcanics in southeastern Turkey.

The deep-water carbonate-volcanic succession in the Kyrenia Range is floored by breccias containing deformed and metamorphosed clasts correlated with underlying Mesozoic units (Fig. 18). Locally, these breccias are underlain by a poorly exposed, thin (about $25 \mathrm{~m}$ ), little deformed unit of deep-water turbidites, of late Campanian age (Kiparisso Vouno Formation; Baroz, 1979). This unit is important as it exhibits a very varied provenance, including basic and acidic volcanic glass and material derived from Mesozoic shallowand deeper-water sediments (e.g., radiolarite). This volcaniclastic unit is similar in age and composition to the Kannaviou Formation of southwestern Cyprus, and may have formed in a comparable arc-related setting.

The Campanian volcaniclastic sediments, and the Maastrichtian pelagic carbonates and volcanics are underlain by deformed and recrystallized Mesozoic shallow-water carbonates. The latest dated pre-tectonic unit is the Early to Mid?-Cretaceous Hilarion Limestone (Ducloz, 1972; Baroz, 1979; Fig. 18). Tectonic brecciation and recrystallization of these carbonates took place between Early Cretaceous and Campanian time, overlapping with the time of formation of the Troodos ophiolite above a subduction zone within Neotethys further south. At high levels, the platform carbonates were extensively tectonically brecciated to form distinctive jigsaw-type breccias, whereas lower levels were metamorphosed to marbles and schists. Baroz (1979) related this deformation and metamorphism to regional southward emplacement of far-travelled nappes. However, this is not consistent with the presence of an in situ deep water sedimentary cover (turbidites) without evidence of emergence and erosion. Robertson and Woodcock (1986) instead postulated a more local origin of the Kyrenia Range along the northern margin of Neotethys in the Eastern Mediterranean area. They suggested that the brecciation and metamorphism could have taken place in a strike-slip setting. Transtension, or simply extension, would have facilitated rapid exhumation of the metamorphics seen as clasts in the base of the Maastrichtian sedimentary cover. Similar carbonate platform brecciation, associated with crustal extension has been noted in other areas, including southern Greece (Füchtbauer and Richter, 1983; Clift, 1991). Extension (or transtension) would also explain the collapse of the carbonate platform to form a deep-water basin by Campanian time.

During the Triassic-Jurassic and Early Cretaceous the western and central parts of the Kyrenia Range formed part of a gradually subsiding carbonate platform, which is inferred to have formed the northern Neotethys passive margin in the easternmost Mediterranean (Sikhari and Hilarion Formations; Ducloz, 1972; Baroz, 1979; Fig. 18). There is some evidence of extensional fault control in the Late Triassic, probably related to rifting and early spreading of the south- erly Neotethyan oceanic basin. These carbonates are locally underlain by unfossiliferous recrystallized carbonate, the Dikomo Limestones.

The oldest dated rocks within the Kyrenia Range are detached blocks of Permian shallow-water limestone (Kantara Limestone), within Eocene olistostromes. These limestones possibly originated as buildups near the northern margin of the southerly Neotethys during rifting. Comparable Permian limestones are extensively developed around the margins of the Isparta Angle in southern Turkey (Poisson, 1977; Gutnic et al., 1979).

\section{Cilicia-Adana Basin and Onshore Turkey}

To the north of the Kyrenia Range is the Cilicia-Adana Basin (Figs. 6, 7), which is characterized by east-west-trending extensional faults, some of which appear to be still active (Aksu et al., 1992a, 1992b). Available seismic reflection data show that the CiliciaAdana Basin dates from pre-Messinian time. The basin is up to $3 \mathrm{~km}$ deep, and contains thick Messinian evaporites that are slightly deformed by growth-faulting, and overlain by Pliocene-Pleistocene muddy sediments. There is also evidence of localized salt diapirism (Aksu et al., 1992a, 1992b). Estimated sediment thicknesses increase eastward from about $1 \mathrm{~km}$ to about $1.8 \mathrm{~km}$ in the middle part of the Cilicia-Adana basin, and to about $3 \mathrm{~km}$ in the east, near Adana Bay, which experienced input from the Seyhan River. The lower sections of the Cilicia-Adana Basin are not imaged by available, relatively shallow, seismic data, but are assumed to date from the upper Oligocene-early Miocene, the time of marine transgression in the Kyrenia Range (see above). In the west, the Cilicia-Adana Basin is bounded by a fault lineament, the Anamur-Kormakiti Ridge, beyond which is the Antalya Basin (Fig. 6).

The coastal region of southern Turkey opposite Cyprus is dominated by the metamorphic Alanya Massif (Monod, 1977; Fig. 6; see below). In the east, this forms the actual coastline (i.e., near Anamur). Further west, the Alanya Massif is unconformably overlain by Miocene-lower Pliocene marine sediments of the Manavgat Basin (Akay et al., 1982; Flecker, 1995; Flecker et al., 1995; Fig. 6), in which the highest part of the preserved succession is made up of open-marine muddy sediments of early Pliocene age (Glover and Robertson, 1998). Messinian evaporites are not exposed. The upper Miocene succession is dominated by relatively shallow-water muddy and siliciclastic sediments. During the middle Miocene deeper-water turbidites and debris flows (with blocks derived from the Alanya Massif) accumulated, interbedded with bathyal hemipelagic carbonates. Beneath this, the succession in the Manavgat Basin begins with lower Miocene shallow-water carbonates, including patch reefs, that developed along the southern margins of the Alanya Massif.

The Manavgat Basin reflects a phase of initial, early Miocene northward marine transgression over the metamorphic Alanya Massif, followed by abrupt subsidence that ushered in mid-Miocene deeper-water deposition. Accommodation space was gradually filled and the basin progressively shallowed (Flecker et al., 1995). On a regional scale, the Manavgat Basin could be interpreted either as an extensional basin dating from the early Miocene (or earlier), or as a flexural foreland basin related to generally southward thrusting of units in the Taurus Mountains to the north. However, here is little evidence of thrusting of the Beyșehir-Hoyran nappes to the north after the late Eocene (Monod, 1977). The timing of subsidence of the Manavgat Basin is compatible with an origin as part of a flexural foredeep related to southeastward thrusting of the Lycian Nappes (Flecker et al., 1997; Fig. 6).

Two other related Miocene basins are found further northwest, the Köprü and Aksu basins (Fig. 6). Recent Sr-isotope dating shows that the Köprü Basin was initiated in the early Miocene (lower-middle Burdigalian), slightly earlier than similar facies in the Managvat Ba$\sin$. This is consistent with an origin as a foreland basin that migrated 
southeastward with time and was related to the final stages of emplacement of the Lycian Nappes (Flecker et al., 1997). The Köprü and Aksu basins also show evidence of fault reactivation of old lines of crustal weakness in the "basement" related to southeastward thrusting of the Lycian Nappes during the Miocene.

Beneath the Neogene basins is the metamorphic Alanya Massif that is dominated by three thrust sheets, of which the lower and upper ones are composed of high-temperature/low pressure lithologies, while the middle unit comprises high pressure/low temperature blueschists (Okay and Özgül, 1984). The age of the blueschists is inferred to be pre-Maastrichtian, consistent with initial thrusting taking place in the Late Cretaceous. Later, the nappe stack was finally assembled by northward thrusting in Paleocene-Eocene time. The Alanya Massif high-pressure metamorphics were exhumed before the early Miocene, possibly related to a crustal extension event.

Unmetamorphosed Mesozoic rocks (Antalya Complex) are locally exposed beneath the Alanya Massif in an important window (Fig. 7). Successions of Paleozoic age (e.g., Permian limestones) there pass upward into Middle-Late Triassic radiolarian sediments (U. Ulü, pers. comm., 1996), that relate to rifting of the southerly Neotethys and can be correlated with the Antalya Complex.

The Alanya Massif is bordered to the north by the Güzëlsu unit, set within a large east-west topographic depression (Fig. 7). This is comprised of unmetamorphosed units, correlated with Antalya Complex in the Isparta Angle to the west (Monod, 1977). This unit presumably extends beneath the Alanya Massif and crops out in the window to the south, mentioned above. The Güzëlsu unit includes highly deformed Mesozoic deep-sea sediments (e.g., radiolarites), minor volcanics, large masses of shallow-water limestone and ophiolitic fragments, especially sheared serpentinite. These Antalya Complex rocks were thrust northward over a large carbonate platform, the Akseki Platform, in Paleocene-early Eocene time.

Farther north, the Akseki Platform (Fig. 7) is one of series of major Mesozoic carbonate platforms similar to the Bey Dağları carbonate platform unit, further west. The Mesozoic Akseki platform is structurally overlain in the north by the Beyșehir-Hoyran Nappes, which include Mesozoic shallow-water carbonates, radiolarian sediments, and ophiolites (Monod, 1977; Okay and Özgül, 1984). These allochthonous units can be restored to a position within a northerly, "Inner Tauride ocean," separate from the southerly Neotethyan oceanic basin (Şengör and Yilmaz, 1981; Robertson and Dixon, 1984). The Hoyran-Beyşehir Nappes are counterparts of the Lycian Nappes, which were also rooted in the northerly Neotethyan oceanic basin, although the former was finally emplaced in the late Eocene, whereas the latter were only finally emplaced in the late Miocene.

The Antalya Complex rocks of the Güzëlsu unit can be viewed as a small Neotethyan oceanic basin, or deep rift basin (floored by volcanics), located between the Akseki carbonate platform to the north and an "Alanya massif continental fragment" to the south during Mesozoic-early Tertiary time (Robertson et al., 1991). This restoration assumes that the large-scale thrusting was essentially in-sequence so that the thrust sheets can simply be pulled apart to reveal the pre-existing paleogeography. The high-pressure/low-temperature rocks of the Alanya Massif could thus represent another sutured small Neotethyan basin (rift or small oceanic basin) bordered by continental crust to the north and south (Fig. 14A). This basin would have partly closed in the Late Cretaceous, by northwesterly directed subduction, causing initial deformation of the Antalya Complex. Before the midEocene, the already assembled units of the Alanya Massif were thrust over the Antalya Complex and, in turn, over the Akseki carbonate platform to the north (Fig. 14B).

\section{SEGMENT 3: LEVANT BASIN, EASTERN CYPRUS- LATAKIA BASIN-MISIS RIDGE-ADANA BASIN}

This segment (Fig. 5) begins with the eastward extension of the Levant Basin, which is again assumed to be underlain by Mesozoic oceanic crust and extends northward over a broad zone of complex deformation, termed the Cyprus to Latakia Link (Fig. 19) by Kempler (1994). This includes the submerged Misis-Kyrenia Ridge that runs westward into the Kyrenia Range and northeastward into the Misis Mountains. This lineament is bordered to the north by the offshore Adana-Cilicia Basin and the onshore Adana Basin, whereas to the north lie Mesozoic units of the Taurus Mountains. The CyprusLatakia link includes a number of bathymetric features, notably the Latakia Ridge, the Hecataeus Ridge (also known as the Hecataeus Seamount), the Gelendzhik Rise, the Cyprus Basin, and the Iskenderun Basin (Fig. 19).

The boundary between the Africa and Eurasian plates has generally been assumed to be dominated by left-lateral strike-slip between Cyprus and the northern Levant margin (e.g., Jackson and McKenzie, 1989). This area is critical to understanding the process of incipient continental collision in the easternmost Mediterranean area.

\section{Submarine Lineaments}

The following tectonic units are recognized from south to north, based on interpretation of seismic data (Ivanov et al., 1992; Kempler, 1994; Ben-Avraham et al., 1995; Fig. 19). Representative seismic lines are shown as simplified line drawings in Fig. 20.

\section{1) Levant Basin}

Multichannel seismic data reveal several deep undeformed reflectors, interpreted as lower Tertiary-Mesozoic sediments (Kogan and Stenin, 1994). Beneath is a basement that appears to rise toward the Hecataeus Seamount and Cyprus in faulted steps. Seismic resolution decreases in more easterly lines. The eastern Levant Basin is assumed to be floored by Mesozoic crust at the leading edge of the North African plate.

\section{(2) Latakia Ridge}

A narrow arcuate ridge links the Hecataeus Ridge, off southeastern Cyprus, with the Latakia area of the northern Levant margin. This was termed the Latakia Ridge by Ben-Avraham et al. (1995), or the West Taurus Ridge by Kempler (1994). The term Latakia Ridge is preferable since the term West Taurus ridge could be confused with the Taurus Mountains of southern Turkey. The Latakia Ridge is bordered in the south by a relatively shallow sedimentary basin (about $100 \mathrm{~m}$ deep by $<2 \mathrm{~km}$ wide; Fig. 20B, C). This basin can be traced westward and correlated with the more pronounced Northern basin ("Cyprus Trench") separating the Eratosthenes Seamount from Cyprus (Fig. 15). Multichannel seismic data reveal that the basin south of the Latakia Ridge has experienced compression, marked by steep folds and inferred evaporite diapirism (Kogan and Stenin, 1994). Single-channel seismic data reveal that inferred Messinian evaporites pinch out northward from the Levantine Basin toward the Latakia Ridge, as do relatively transparent Pliocene sediments (Kempler, 1994; Fig. 20B, C).

In the east, the southern boundary of the Latakia Ridge is a steep feature, whereas in the west it merges gradually with the Hecataeus Ridge. Multichannel seismic data reveal that the southern side of the Hecataeus Ridge is folded and cut by southward-dipping steep faults (Kogan and Stenin, 1994). The Hecataeus Ridge rises to $250 \mathrm{~m}$ below sea-level and comprises twin highs in its central, shallowest part (Kempler, 1994). The Hecataeus lineament extends westward to connect with the Akrotiri lineament, identified using shallow seismic data (McCallum et al., 1993).

The Hecataeus Ridge is marked by a magnetic anomaly that merges with the larger regional anomaly characteristic of the Troodos ophiolite. An implication is that the Hecataeus Ridge is an offshore extension of the Cyprus ophiolite. A less likely alternative origin is that it is an accreted crustal unit, more similar to the Eratosthenes Seamount. Seismic profiles of the Hecataeus Ridge reveal a relatively thin, nearly transparent Pliocene-Pleistocene succession, under- 


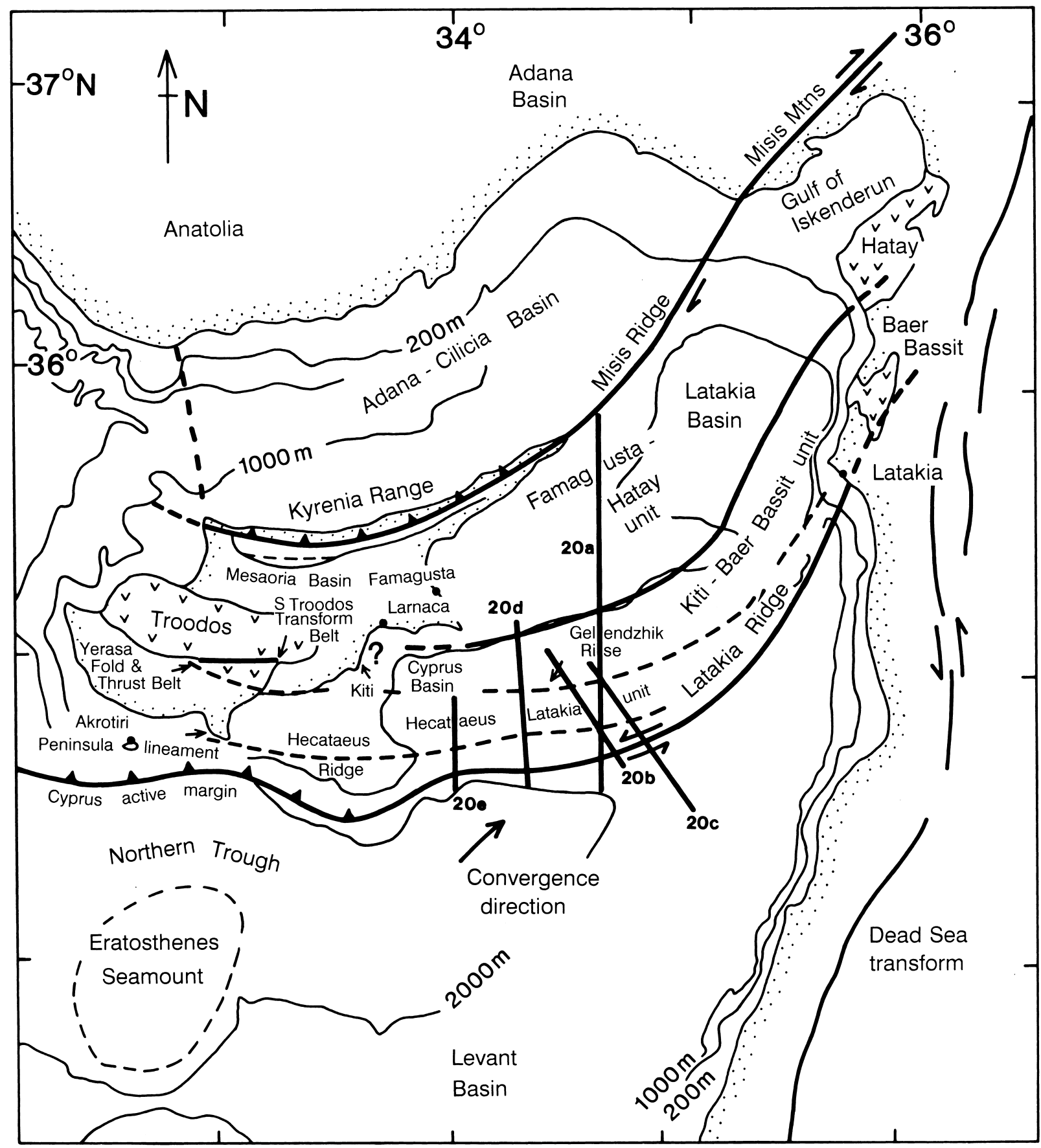

Figure 19. Tectonic map showing the main features of the Cyprus-Latakia link zone and areas to the north and south. Data sources are given in the text.

lain by a relatively steeply dipping, folded lower unit (Fig. 20E), similar to the seismic stratigraphy of the Akrotiri lineament (McCallum et al., 1993). Messinian evaporites are absent from both the Hecataeus Ridge, and from the Latakia Ridge further east, suggesting that these areas were raised, emergent features during the Messinian salinity crisis (Kempler, 1994; Ben-Avraham et al., 1995).

Kempler (1994) suggested that the Hecataeus and Latakia ridges were above sea level in the Messinian, followed by marked subsidence in post-Messinian time. Subsidence was even greater in the Levant Basin in the south "due to a bigger Messinian and younger sediment load" (Kempler, 1994). However, the level of the Hecataeus and Latakia ridges in the Messinian is not constrained and need not have been near global eustatic sea-level. An alternative explanation of the topographic height difference between the Hecataeus and Latakia ridges and the Levant Basin to the south is that the Levant Basin formed part of the leading edge of the downgoing North African plate, which was correspondingly downflexed, whereas the Hecataeus and Latakia ridges to the north experienced corresponding flexural uplift (of the upper plate margin). Similarly, the Eratosthenes Seamount was downflexed after Messinian?-early Pliocene, while the Akrotiri lineament to the north was uplifted to near sealevel and colonized by Upper Miocene reefs.

\section{(3) Southeast Cyprus to Latakia unit}

This arcuate strip of seafloor runs from southeast Cyprus to the northern Levant coast near Latakia and encompasses the Gelendzhik 


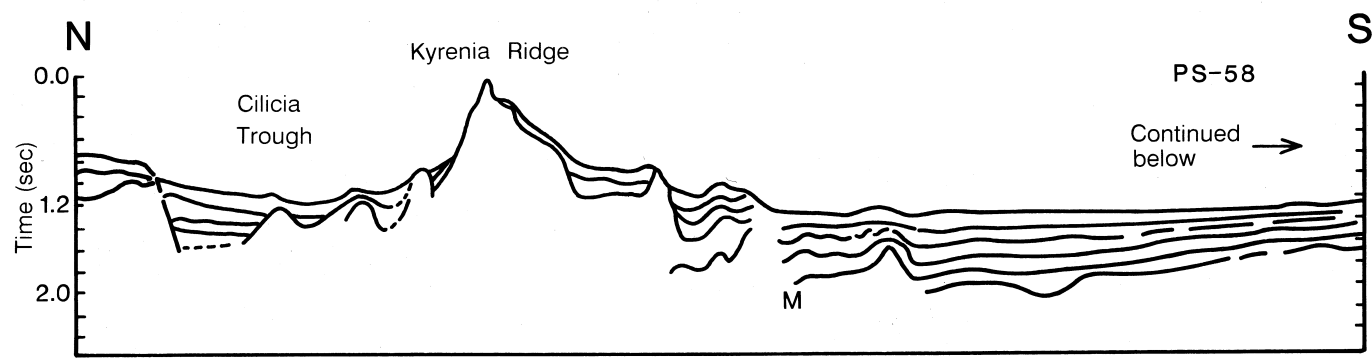

\section{A}

Larnaca Ridge

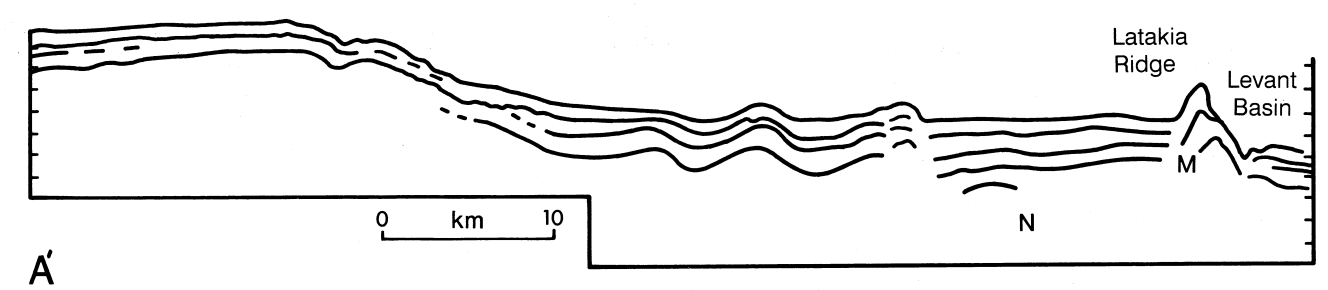

$A^{\prime}$
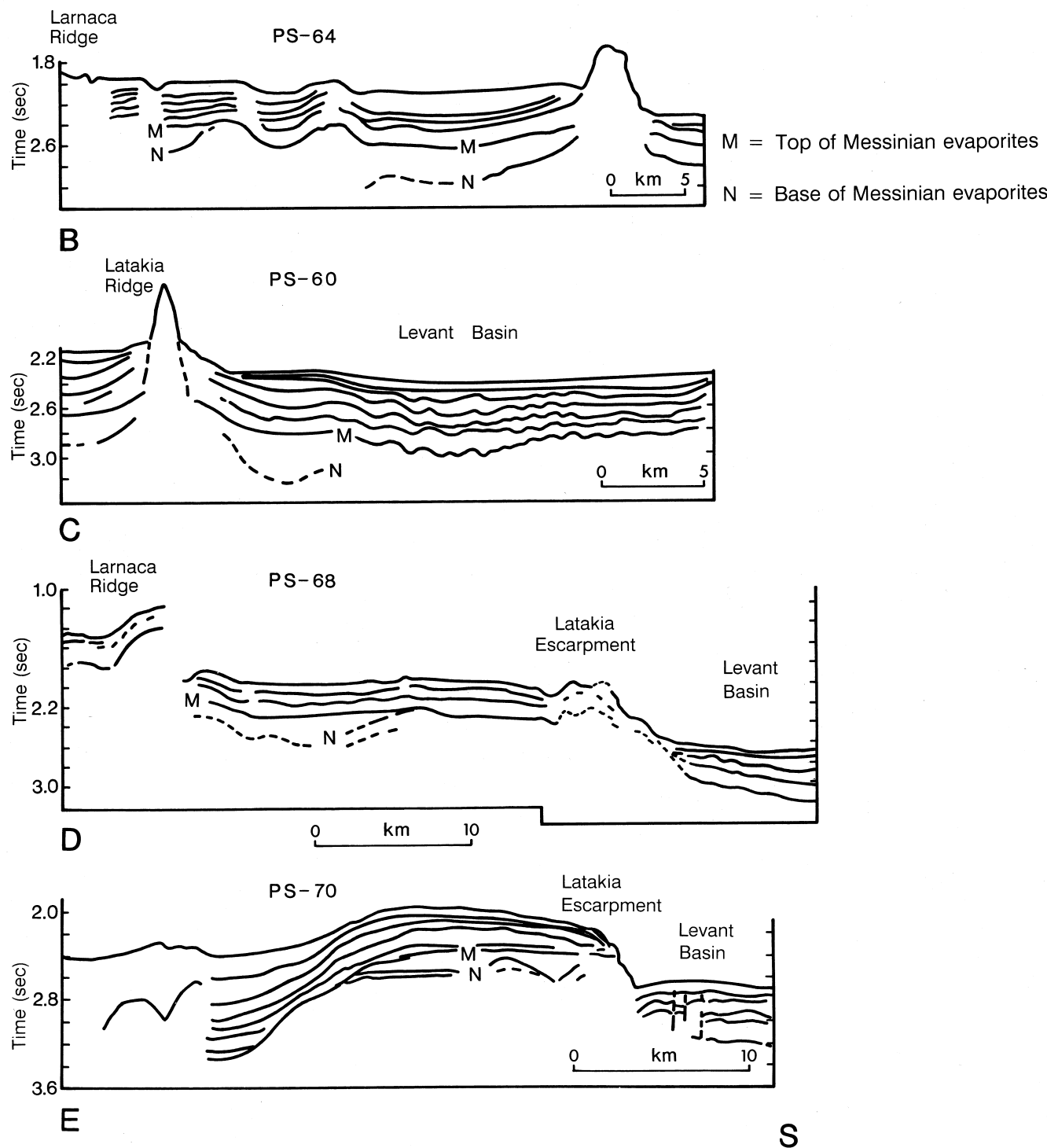

Figure 20. Interpretative line drawing based on seismic profiles across part of the Cyprus-Latakia link zone. The seismic profiles are published in Ben-Avraham et al. (1995). See Figure 19 for locations. 
High, or Gelendzhik Rise (Fig. 19). This area was separated into two units by Kempler (1994), namely the Hecataeus-Latakia unit in the south and the Kiti to Baer-Bassit unit in the north. Ben-Avraham et al. (1995) show the boundary between these two units as a top-to-thesouth thrust in the west, but as a sinistral strike-slip fault in the east. However, the evidence for this distinction is not made clear. The southern margin of the Hecataeus-Latakia unit rises relatively gently to the Latakia Ridge in the west, whereas further east this unit is shown as wedging out against the Latakia Ridge (Fig. 20B, C). Where traced onshore in eastern Cyprus, the boundary between the two subunits recognized by Ben-Avraham et al. (1995) does not correspond with any known structural break.

Within the Hecataeus-Latakia unit, a prominent reflector at the base of a sedimentary unit pinches out toward the crest of the Latakia Ridge to the south. Kempler (1994) followed Biju-Duval et al. (1977) in interpreting this as the front of a major unit of south-facing thrust sheets, which was assumed to relate to closure of Neotethys in the Late Cretaceous. However, Ivanov et al. (1992) instead interpret this conspicuous reflector as the base of the Messinian evaporite sequence, implying that the ridge beneath it originated before the Messinian, any exotic units being much more deeply buried. This second interpretation is consistent with the geology of the Akrotiri Peninsula on-strike to the west (Fig. 9), where a topographic high existed in the Late Miocene, as noted above. South-verging thrusting took place in southern Cyprus to form the Yerasa Fold and Thrust Belt (Fig. 9). This correlation with on-land geology thus does not support Kempler's (1994) suggestion that her Hecataeus-Latakia unit is "mélange" similar to that of southern and western Cyprus (i.e., the Moni mélange or the Mamonia Complex, respectively) or a fragment of Mesozoic Arabian continental crust. A simpler explanation, consistent with the regional magnetic data (Rybakov et al., 1994), is that the Hecataeus-Latakia unit is an eastward extension of the Troodos ophiolite and its sedimentary cover (Fig. 19). This unit was deformed along the plate boundary in the south to form an elongate high not long before (Fig. 20B) the Messinian; most of the deformation of the ridge is thus of post-Messinian age.

Also within the Hecataeus-Latakia unit (but straddling the contact with the Kiti to Baer-Bassit unit in the north) is the Gelendzhik High, identified as a Pleistocene feature ("a peculiar quadrilateral high"; Kempler, 1994), based on the presence of uplifted unconsolidated sediments in both crestal and lower slope areas (Ivanov et al., 1991). The Gelendzhik High appears to be a young uplifted feature, possibly a back-tilted fault block. It then passes westward into the prominent Cyprus Basin located off southeastern Cyprus that contains about 1 $\mathrm{km}$ of post-Miocene sediments (Fig. 19).

The more northerly Kiti to Baer-Bassit unit runs offshore from Larnaca, through the southern part of the Cyprus Basin to link up with the onshore Baer-Bassit ophiolite area (Fig. 19). In the east, the boundary merges with the Latakia Ridge (Fig. 20B, C), which was suggested by Ben-Avraham et al. (1996) to be a Mesozoic thrustfault. This boundary may instead represent the deformed trailing edge of the Eurasian plate to the north, as suggested above. According to Kempler (1994), the southern boundary of the Kiti to BaerBassit unit lines up with the southern margin of the Gelendzhik Rise. However, the bathymetric data show that the Gelendzhik Rise in fact straddles this boundary.

Kempler (1994) interpreted the Kiti to Baer-Bassit unit as thrust sheets that were emplaced onto an ophiolitic basement associated with late Eocene-early Oligocene tectonic juxtaposition of the Troodos ophiolite within the Kyrenia Range to the north. However, a problem here is that the Kiti to Baer-Bassit unit passes westward into southern Cyprus where unbroken deep-sea carbonate deposition (Lefkara Formation) continued during this time. Ben-Avraham et al. (1996) join up the southern boundary of the Kiti to Baer-Bassit unit (their Larnaca Ridge) with the Yerasa Fold and Thrust Belt, located within the foothills of the Limassol Forest (Fig. 9). The Yerasa linea- ment formed by compression in the early Miocene (or slightly earlier), and had become inactive by the late Langhian, when it was transgressed by undeformed shallow-marine carbonates. A correlation of the Yerasa lineament with the southern boundary of the Kiti to BaerBassit unit would imply that this feature might have developed in the Miocene, possibly along a pre-existing zone of weakness. This lineament might have been reactivated later, in the late Miocene-Pleistocene. Indeed, the Yerasa lineament onshore was cut by later extensional faults of pre-Pliocene age. However, there is little evidence that the Yerasa lineament was markedly active in the Pliocene-Pleistocene.

The area offshore from southeastern Cyprus (Larnaca Bay) is characterized by the Cyprus Basin, about $50 \mathrm{~km}$ wide and $2 \mathrm{~km}$ deep. Examination of seismic profiles suggests that this feature is likely to be a large Pliocene-Pleistocene half graben. Similarly, seismic profiles of the Kiti to Baer-Bassit unit further east indicate the presence of small graben-like structures of probable Pliocene-Pleistocene age.

In summary, the Kiti to Baer-Bassit unit is here inferred to be an eastward extension of the Troodos ophiolite and its sedimentary cover. The southern margin of the Kiti to Baer-Bassit unit (Latakia Ridge and Escarpment) is a possible early Miocene compressional feature. The Kiti to Baer-Bassit unit was deformed with both extensional (Cyprus Basin) and compressional structures (Gelendzhik High) in the Pliocene-Pleistocene. These structures were probably generated by left-lateral transtension and transpression along the Africa-Eurasian plate boundary between Cyprus and the Levant.

\section{Famagusta-Hatay Unit}

This unit, named by Kempler (1994), is bounded by the KyreniaMisis Ridge to the north and by what Ben-Avraham et al. (1995) termed the Larnaca Ridge to the south (Fig. 20A). Ben-Avraham et al. (1995) further subdivided this unit into two subunits, separated by an inferred top-to-the-south thrust in the west, located directly off Famagusta, then passing eastward into an inferred strike-slip zone. Kempler (1994) noted the existence of a several-hundred-meter-high bathymetric step marking the southern boundary of the FamagustaHatay unit, and inferred the existence of a south-facing thrust or nappe front that does not displace Miocene sediments. Multichannel seismic reflection profiles reveal this "boundary" as a wide fault zone cut by small subparallel displacement features (Kogan and Stenin, 1994). Kempler (1994) suggested that these faults might represent a shallow-level expression of deeper seated strike-slip faults. Messinian evaporites are thin or absent on the upper, northerly side of the unit, whereas they are present on the southern lower side, suggesting the existence of a southward topographic slope in the late Miocene (Kempler, 1994).

An interpretation of the regional magnetic anomaly data (Rybakov et al., 1994) suggests that the Famagusta-Hatay unit is underlain by an eastward extension of the Troodos ophiolite. Onshore, the sedimentary cover of the ophiolite is unbroken from Maastrichtian onward, and thus there is no evidence to support the existence of preMiocene thrust sheets offshore. The southern boundary of the Famagusta-Hatay unit in the west near Cyprus (the Larnaca Ridge), is very unlikely to be a major thrust fault zone (c.f., Ben-Avraham et al., 1995). Traced westward, the Larnaca Ridge trend lines up with the Upper Cretaceous South Troodos Transform Fault Zone (Fig. 9). However, this fault zone was inactive after the Late Cretaceous, as shown by the fact that the overlying Maastrichtian-early Tertiary Lefkara Formation to the east is not affected.

Examination of seismic profiles of the south margin of the Famagusta-Hatay unit (Larnaca Ridge; Fig. 20A) suggests that, rather than being a thrust front, this lineament can be best interpreted as a Pliocene-Pleistocene extensional, or possibly transtensional feature (e.g., a series of back-tilted fault blocks). Conceivably, this lineament marks an eastward extension of the Upper Cretaceous South Troodos 


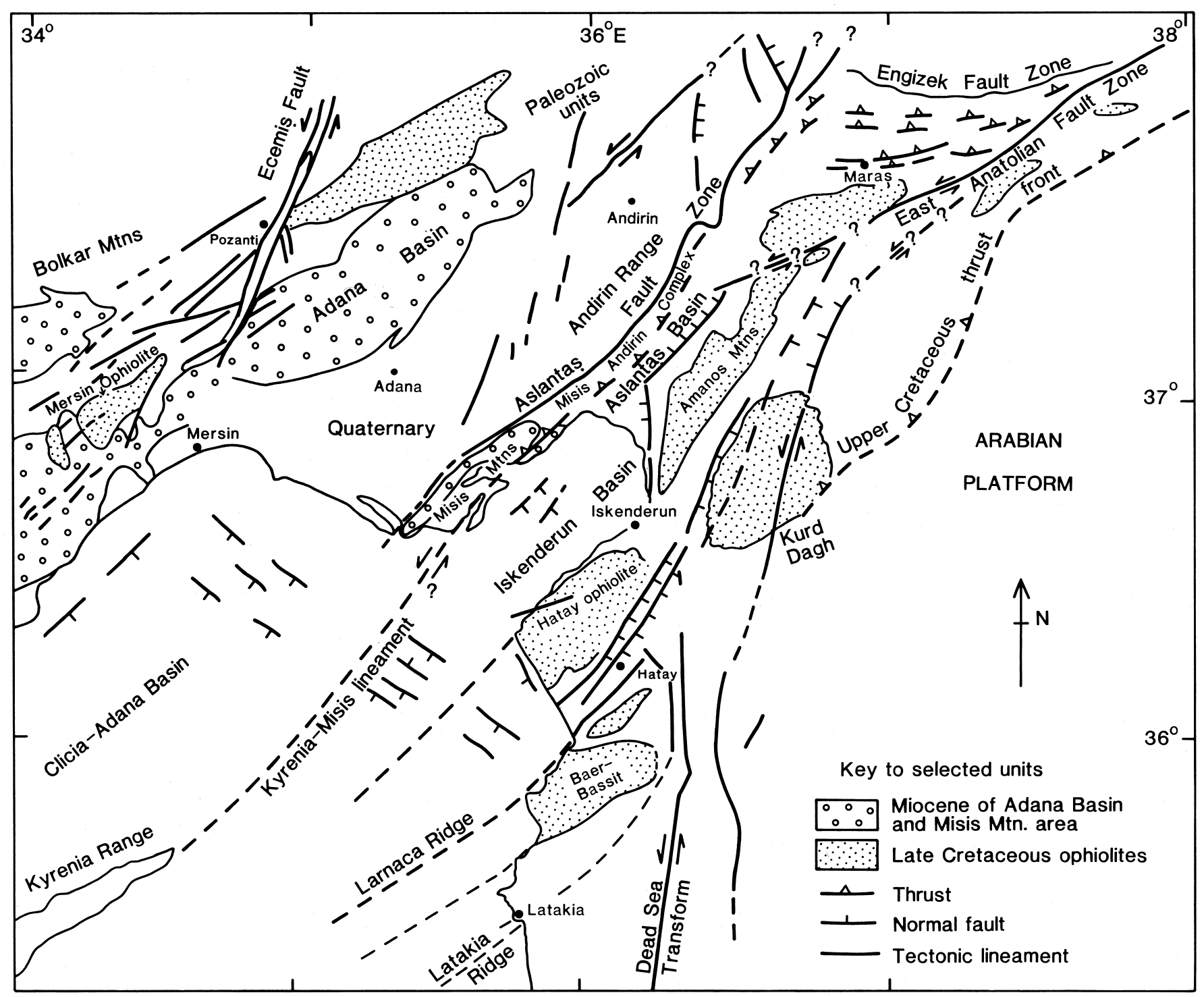

Figure 21. Map of the main tectonic lineaments in the northeasternmost corner of the Mediterranean area. Onshore data from Karig and Közlü (1990) and Kelling et al. (1987); offshore data from Aksu et al. (1992a).

Transform Zone. If so, faults affecting the Larnaca Ridge could reflect periodical reactivation of zones of weakness within an underlying ophiolitic basement.

In the east, the Famagusta-Hatay unit is overlapped by the large Latakia Basin, or Latakia Trough, >1400 m deep (Fig. 19). This contains relatively thick Messinian evaporites, overlain by about $1 \mathrm{~km}$ of Pliocene-Pleistocene sediments. The Latakia Basin developed as a Miocene extensional basin. The basin is cut by normal faults that terminate downward on Messinian evaporites, giving rise to a large southwest-northeast trending roll-over anticlinal structure. The coast to the east is bordered by high-angle faults (Aksu et al., 1992a; Fig. 21A). The basin passes westward into a shallower area of subdued topography and then onshore into the Mesaoria basin, between the Troodos ophiolite and Kyrenia Range. As noted earlier the Mesaoria basin has a complex history. This included middle to late Miocene extensional faulting, both along the front of the Kyrenia Range (Kithrea Fault) and within the Mesaoria area. There was also late Miocene-early Pliocene extensional faulting within the Mesaoria Basin and along the northern Troodos margin. A similar history could apply to the adjacent Latakia Trough.

\section{Discussion of Onshore-Offshore Correlations}

Recent interpretations of the Cyprus-Latakia Link zone assume that the area is a stack of thrust sheets, including ophiolites and mélange that were emplaced southward during final closure of Neotethys in the latest Cretaceous (Kempler, 1994; Ben-Avraham et al., 1995; Table 2). This assumption is based on an earlier view that all the Mesozoic allochthonous units, including ophiolites, were thrust from far to the north in the Upper Cretaceous (e.g., Biju-Duval et al., 1977). There is, however, no direct evidence of any such east-westtrending Upper Cretaceous thrust features on Cyprus, or on offshore seismic profiles. On the other hand, the Cyprus-Latakia link zone does connect eastward with the southern margin of the Baer-Bassit ophiolite and related units, that, together with the Hatay ophiolite further north, were, indeed, emplaced generally southward onto the westerly edge of the Arabian continental margin in the latest Cretaceous (Delaune-Mayere et al., 1976; Fig. 6). The zone of Late Cretaceous thrust emplacement is thus inferred to have terminated westward, near the north-south Levant margin, and beyond this the Troodos ophiolite remained submerged within a remnant of the southerly 
Table 2. Summary of the main tectonic-sedimentary features and previous and present interpretations of tectonic lineaments, between Cyprus and the northern Levant margin.

\begin{tabular}{|c|c|c|c|c|}
\hline Unit & $\begin{array}{l}\text { Longitude of Cyprus } \\
\text { Segments } 1 \text { and } 2\end{array}$ & $\begin{array}{l}\text { Between Cyprus \& } \\
\text { Levant Margin } \\
\text { Segment } 3\end{array}$ & Earlier interpretation & Interpretation-this study \\
\hline $\begin{array}{l}\text { Onshore Southeast } \\
\text { Turkey }\end{array}$ & $\begin{array}{l}\text { In west, continental basement } \\
\text { (Alanya Massif) transgressed } \\
\text { in early Miocene, then } \\
\text { subsides rapidly in middle } \\
\text { Miocene followed by uplift in } \\
\text { Late Miocene, then north- } \\
\text { south extensional faulting in } \\
\text { Pliocene-Quaternary. }\end{array}$ & $\begin{array}{l}\text { In east, Adana Basin. } \\
\text { Transgression in early } \\
\text { Miocene; deepening upwards } \\
\text { in middle Miocene; regression } \\
\text { in late Miocene, then } \\
\text { nonmarine. }\end{array}$ & $\begin{array}{l}\text { Both Manavagat Basin in west } \\
\text { and Adana Basin in east seen } \\
\text { as foreland basins related to } \\
\text { southward thrust and nappe } \\
\text { emplacement. }\end{array}$ & $\begin{array}{l}\text { Adana and Manavgat basins } \\
\text { alternatively related to crustal } \\
\text { extension driven by "roll- } \\
\text { back" of relict "Kyrenia slab" } \\
\text { and/or subduction south of } \\
\text { Cyprus. }\end{array}$ \\
\hline Cilicia-Adana Basin & $\begin{array}{l}\text { Evidence in Kyrenia Range } \\
\text { suggests land area extended to } \\
\text { south Turkey, then submerged } \\
\text { rapidly in the Late Oligocene, } \\
\text { Early Miocene. }\end{array}$ & $\begin{array}{l}\text { Seismic records indicate } \\
\text { subsiding extensional basin, } \\
\text { confirmed by TPAO drilling in } \\
\text { Gulf of Iskenderun. }\end{array}$ & $\begin{array}{l}\text { Extensional basin predating } \\
\text { Messinian evaporites. }\end{array}$ & $\begin{array}{l}\text { East-west crustal extension } \\
\text { mainly Late Oligocene-- } \\
\text { Miocene owing to roll-back of } \\
\text { relict slab under Kyrenia } \\
\text { lineament, and/or activation of } \\
\text { new subduction zone south of } \\
\text { Cyprus. }\end{array}$ \\
\hline $\begin{array}{l}\text { Kyrenia-Misis } \\
\text { Lineament }\end{array}$ & $\begin{array}{l}\text { Uplifted in the Late Pliocene, } \\
\text { mid-Pleistocene; active margin } \\
\text { undergoing northward } \\
\text { subduction in late Eocene- } \\
\text { early Oligocene; initial } \\
\text { deformation in Upper } \\
\text { Cretaceous. }\end{array}$ & $\begin{array}{l}\text { Submerged Misis Ridge links } \\
\text { with Misis Mountains of } \\
\text { Southern Turkey; Misis Ridge } \\
\text { bounded by steep faults. }\end{array}$ & $\begin{array}{l}\text { Compression in Misis } \\
\text { Mountains, transpression in } \\
\text { offshore segments; mainly } \\
\text { strike-slip lineament } \\
\text { (Kempler, 1994). }\end{array}$ & $\begin{array}{l}\text { Strike-slip in Kyrenia Range } \\
\text { related to upper Cretaceous- } \\
\text { lower Tertiary paleorotation of } \\
\text { Troodos microplate and late } \\
\text { Miocene-Holocene westward } \\
\text { "tectonic escape" of Anatolia. }\end{array}$ \\
\hline $\begin{array}{l}\text { "Famagusta-Hatay } \\
\text { Unit" of Kempler, } \\
\text { (1994) }\end{array}$ & $\begin{array}{l}\text { Onshore Upper Cretaceous- } \\
\text { Pleistocene sedimentary cover } \\
\text { is unbroken; on strike with } \\
\text { Cretaceous oceanic south } \\
\text { Troodos Transform Fault Zone } \\
\text { to west. }\end{array}$ & $\begin{array}{l}\text { Offshore geophysics suggests } \\
\text { extension of Troodos-type } \\
\text { ophiolite. }\end{array}$ & $\begin{array}{l}\text { Thrust front passing eastward } \\
\text { into strike-slip fault (Ben- } \\
\text { Avraham et al., 1995); South- } \\
\text { verging deep thrust fault or } \\
\text { nappe front (Ivanov et al., } \\
\text { 1991); possible splays of deep- } \\
\text { strike-slip faults (Kempler, } \\
\text { 1994). }\end{array}$ & $\begin{array}{l}\text { Eastward extension of Troodos } \\
\text { ophiolite, cut by small } \\
\text { extensional, (or transtensional) } \\
\text { faults of mainly Miocene- } \\
\text { ?Pliocene age; no major thrust } \\
\text { or strike-slip system. }\end{array}$ \\
\hline $\begin{array}{l}\text { “Kiti-Baer Bassit } \\
\text { Unit" of Kempler } \\
\text { (1994) }\end{array}$ & $\begin{array}{l}\text { Unbroken Upper Cretaceous- } \\
\text { Pleistocene sedimentary } \\
\text { cover; south margin coincides } \\
\text { in east with Yerusa Fold and } \\
\text { Thrust Belt, on early Miocene } \\
\text { compressional lineament. }\end{array}$ & $\begin{array}{l}\text { Southern boundary not well } \\
\text { marked and lines up with West } \\
\text { Tartus or Latakia Ridge in the } \\
\text { east and with the } \\
\text { superimposed Cyprus } \\
\text { depression and Gelendzhik } \\
\text { Rise in the west (Kempler, } \\
\text { 1994). }\end{array}$ & $\begin{array}{l}\text { Interpreted as a thrust in west } \\
\text { and strike-slip fault in east } \\
\text { (Ben-Avraham et al., 1995); } \\
\text { contradicted by onshore } \\
\text { geology, as no compression is } \\
\text { seen there since early } \\
\text { Miocene. }\end{array}$ & $\begin{array}{l}\text { Latakia Ridge in east is main } \\
\text { plate boundary; "boundary" in } \\
\text { west more likely to be a } \\
\text { Pliocene-Pleistocene half } \\
\text { graben (no evidence it is older } \\
\text { feature). }\end{array}$ \\
\hline $\begin{array}{l}\text { "Hecataeus-Latakia } \\
\text { Unit" of Kempler } \\
\text { (1994) }\end{array}$ & $\begin{array}{l}\text { Passes laterally into onshore } \\
\text { succession that experienced } \\
\text { early Miocene compression, } \\
\text { minor Late Miocene } \\
\text { extension, then little faulting } \\
\text { in Pliocene-Quaternary. }\end{array}$ & $\begin{array}{l}\text { Hecataeus seamount in the west } \\
\text { is seen as extension of Troodos } \\
\text { ophiolitic basement and } \\
\text { sedimentary cover; in east } \\
\text { narrow lineament with south } \\
\text { side steeper than north side. }\end{array}$ & $\begin{array}{l}\text { Prominent reflector at base of } \\
\text { sedimentary unit is interpreted } \\
\text { as south-facing nappes (Biju- } \\
\text { Deval et al., 1997; Kempler, } \\
\text { 1994) or as pre-Messinian } \\
\text { feature of different origin } \\
\text { (Ivanov et al., 1997). }\end{array}$ & $\begin{array}{l}\text { In west, see merging of } \\
\text { Hecataeus Ridge with main } \\
\text { plate boundary; Hecataeus } \\
\text { may correlate with Akrotiri } \\
\text { Peninsula; possible left-lateral } \\
\text { strike slip in east, but no } \\
\text { buried major nappes can be } \\
\text { inferred. }\end{array}$ \\
\hline $\begin{array}{l}\text { "Latakia Ridge" } \\
\text { Ben-Avraham et } \\
\text { al. (1995); "West } \\
\text { Taurus Ridge" of } \\
\text { Kempler (1994) }\end{array}$ & $\begin{array}{l}\text { Westward extension runs south } \\
\text { of Cyprus. }\end{array}$ & $\begin{array}{l}\text { Messinian evaporites apparently } \\
\text { absent from both Hecataeus- } \\
\text { Latakia unit; was above sea- } \\
\text { level in the Messinian, then } \\
\text { subsided (Kempler, 1994). }\end{array}$ & $\begin{array}{l}\text { Subsidence rate in Levant Basin } \\
\text { to the north was greater than } \\
\text { subsidence south of Tartus } \\
\text { Ridge because of a bigger } \\
\text { Messinian and younger aged } \\
\text { sediment load (Kempler, } \\
\text { 1994). }\end{array}$ & $\begin{array}{l}\text { Latakia Ridge is caused by } \\
\text { eastward change from oblique, } \\
\text { north-east subduction to } \\
\text { mainly sinistral strike-slip } \\
\text { (i.e., transpressional). }\end{array}$ \\
\hline $\begin{array}{l}\text { "Northern Trough" } \\
\text { and Eratosthenes }\end{array}$ & $\begin{array}{l}\text { Located south of Akrotini } \\
\text { Peninsula of Cyprus and its } \\
\text { eastward extension. }\end{array}$ & $\begin{array}{l}\text { South of Cyprus deep-sediment- } \\
\text { filled trough interpreted as } \\
\text { Pliocene-Quaternary } \\
\text { turbidites; shallower trough is } \\
\text { seen in front of Latakia Ridge } \\
\text { southern slope. }\end{array}$ & $\begin{array}{l}\text { In west, "moat" of Eratosthenes } \\
\text { Seamount generated by high- } \\
\text { angle faulting; in east, } \\
\text { bathymetry mainly reflects } \\
\text { differential sediment loading. }\end{array}$ & $\begin{array}{l}\text { Subduction trench in west down } \\
\text { which Eratosthenes is being } \\
\text { subducted; shallower trench in } \\
\text { east where subduction is more } \\
\text { oblique to pure strike-slip. }\end{array}$ \\
\hline Levantine Basin & $\begin{array}{l}\text { South of Eratosthenes Peninsula } \\
\text { at longitude of Cyprus; thick } \\
\text { Tertiary-Mesozoic sediments } \\
\text { in inferred oceanic basin. }\end{array}$ & $\begin{array}{l}\text { South of Latakia Ridge in E; } \\
\text { thick Tertiary-Mesozoic } \\
\text { sediments on inferred oceanic } \\
\text { basement. }\end{array}$ & $\begin{array}{l}\text { Any oceanic crust no older than } \\
\text { Cretaceous (Dercourt et al., } \\
\text { 1986); but Triassic for others. }\end{array}$ & $\begin{array}{l}\text { Thick sediments on Triassic- } \\
\text { Early Jurassic? oceanic } \\
\text { basement. }\end{array}$ \\
\hline
\end{tabular}

Note: See text for explanation. 
Neotethyan oceanic basin into the Tertiary (Robertson, 1990). The Troodos ophiolite underwent counterclockwise rotation in Campanian-early Eocene time (Clube et al., 1985). Sheeted dykes in the Hatay ophiolites are orientated nearly east-west, unlike the northsouth trend in Cyprus (Parrot, 1977), and it is inferred that the rotated "Troodos microplate" did not extend as far east as the Hatay and Baer-Bassit ophiolites (Clube and Robertson, 1986). The Late Mesozoic basement of the Cyprus-Latakia Link zone is probably very complex and should not be interpreted simply as a stack of east-westtrending thrust sheets. Mélange units may indeed be present, but are likely to lie at great depth beneath a regional extension of Upper Cretaceous ophiolites. Instead, most of the structure imaged by seismic profiles dates from Neogene-Holocene time.

It is widely believed that a zone of broad distributed left-lateral strike slip connects the Cyprus trench in the west with the East Anatolian Transform in the east (Kempler, 1994; Ben-Avraham et al., 1995). The majority of the boundaries between the various units of the Cyprus-Latakia Link are seen as left-lateral strike-faults. The main problem here is that none of these faults (south of the MisisKyrenia Ridge) have an obvious expression onshore in eastern $\mathrm{Cy}-$ prus during Neogene-Holocene. Lineaments were initially drawn right across Cyprus by Ivanov et al. (1992), but were then more conservatively drawn to affect only eastern coastal areas by Ben-Avraham et al. (1995). Correlation with onshore features was heavily influenced by an early paper by Bagnall (1964), that predated modern work on the sedimentary cover of the Troodos ophiolite. Bagnall's strike-slip lineaments were speculative and have not been confirmed by more recent work. On the other hand, seismic interpretation suggests that strike slip (both transpression and transtension) is active within the Cyprus-Latakia Link (Aksu, 1992a, 1992b). It is likely that strike-slip was concentrated along the Latakia Ridge in the south and the Misis-Kyrenia Ridge in the north, whereas the Troodos ophiolite and marine areas to the northeast (underlain by ophiolitic crust) remained as relatively competent units.

In summary, the basement of the Cyprus-Latakia Link (south of the Misis Ridge) is interpreted as heavily tectonized Upper Cretaceous ophiolite. From the early Miocene onward the plate boundary was located south of the Latakia Ridge, with northward subduction of Mesozoic oceanic crust of the Levant Basin. During the late Miocene-early Pliocene, the upper plate was affected by crustal extension, probably exploiting basement weakness zones, as seen on Cyprus to form, e.g., the Latakia Trough and Iskenderun Basin. After the late Miocene, Anatolia began its westward escape, and subduction in the Eastern Mediterranean was toward the northeast, initiating major strike-slip along the main plate boundary to the south, giving rise to Pliocene-Pleistocene extensional, or transtensional basins.

\section{Kyrenia-Misis Lineament}

The Kyrenia-Misis lineament is a major structural and topographic feature that runs from the Kyrenia Range under the sea and emerges as the relatively subdued Misis Mountains in southern Turkey (Evans et al., 1978; Aksu et al., 1992a, 1992b; Fig. 19).

Offshore, the Kyrenia-Misis lineament forms a well-defined bathymetric ridge, the Misis Ridge, which remained mainly free of sediments, whereas basins were formed to the north and south along extensional (or transtensional) faults. Aksu et al. (1992a, 1992b) interpreted the lineament as a narrow horst, bounded by strike-slip faults. Messinian evaporites pinch out against the Kyrenia-Misis Ridge, showing that it was already a positive feature in the late Miocene. Kempler (1994) also interpreted the steep oblique faults bordering the Kyrenian-Misis bathymetric ridge as reflecting strike-slip. The submerged Misis Ridge was seen as transtensional in origin, in contrast to the Kyrenia Range and Misis Mountains, to the west and east respectively, that were transpressional. Mapped Pliocene-Pleistocene extensional faults trend at right angles to the Misis-Kyrenia Ridge (Fig. 21). This extension is attributed to regional strike-slip, with individual listric faults soling out on Messinian evaporite (Aksu et al., 1992a, 1992b).

\section{Adana Basin and Adjacent Units}

To the northwest of the Kyrenia-Misis lineament is the offshore Cilicia-Adana Basin, and the onshore Adana Basin. The onshore extension (Misis Mountains and Andırın Range) is discussed later. To the northwest the Adana Basin is bounded by the left-lateral Ecemiş Fault Zone that is estimated to have an offset of up to $80 \mathrm{~km}$, although this is not well constrained (Yetiș, 1984, Yalçin and Görür, 1984; Gökçen et al., 1988). Pleistocene fluvial terraces are locally offset by the transform (Yetiş, 1978). During the Oligocene-Miocene coarse clastic sediments and breccias accumulated within a depression apparently created by the transform. According to Yetiș (1984), the Ecemiș Fault Zone was already active in late Eocene time. If correct, the Fault Zone could have accommodated the effects of collision of microcontinents and closure of the northern strand of Neotethys.

Within the onshore Adana Basin, seismic stratigraphic interpretations indicate the presence of three megasequences (Williams et al., 1995; Fig. 22). Relevant questions include the cause of Oligocene and early Miocene extensional faulting and mid-Miocene deepening. Oligocene sediments further north are reported to exhibit compression in the late Oligocene. Williams et al. (1995) relate extensional faulting to renewed thrusting in the Taurides to the north. A problem, however, is that the sediments within the Adana Basin are everywhere mapped as unconformably overlying the basement (Mesozoic Tauride units). Williams et al. (1995) invoke the existence of concealed thrusts beneath the northern margin of the Adana Basin to cause flexural loading and faulting of the foreland. An alternative is that the faulting is related to regional extension originating to the south, rather than crustal loading driven from the north (see below).

During the upper Eocene, allochthonous units were emplaced southeastward over Taurus carbonate platforms to their final position (Fig. 6). This was followed by erosion, then fault-controlled subsidence in the Oligocene, with initially terrestrial deposition (Fig. 22). Faulting continued into the early Miocene when Miocene reefs accumulated on rotated fault blocks, and shallow- to deeper-marine clastics accumulated in intervening fault-controlled basins. A relative sea-level high in the mid-Miocene (Langhian) caused northward migration of reefs. Late Miocene (Langhian-Serravallian) time was marked by deposition of turbidites passing upward into shallowmarine, then continental deposits. Paleocurrents are initially toward the south and southeast, then later toward the southwest (Gökçen et al., 1988; Gürbüz, 1993; Gürbüz and Kelling, 1993).

The northwestern margin of the Adana Basin exposes Mesozoic carbonate platform units of the Bolkar Mountains (Özgül, 1984; Fig. 21). These are tectonically overlain by allochthonous units, including the Mersin ophiolite (Fig. 21). High-pressure blueschists occur locally along the contact between the ophiolite and the underlying Bolkar Dağ carbonate platform (Dilek and Moores, 1990). A complete Upper Cretaceous ophiolite (Mesin ophiolite) is present, including a metamorphic sole and underlying polymict mélange unit that can be interpreted as a subduction-accretion complex (Parlak et al., 1995). The Mersin ophiolite has generally been correlated with allochthonous units thrust southward in the late Eocene (Özgül, 1984), driven by the final stages of closure of a northerly Neotethyan oceanic basin ("Inner Tauride Ocean"; Şengör and Yilmaz, 1981; Lwtwyn and Casey, 1995). However, Parlak et al. (1995) suggested that the Mersin ophiolite was emplaced northward from a southerly Neotethyan oceanic basin, although correlation with the northerly derived allochthonous units remains more probable.

\section{Misis-And1r1n Complex: Compression or Extension Related?}

Within the Misis Mountains onshore only Tertiary units are exposed, unlike the Kyrenia Range. The Misis Mountain lineament ex- 


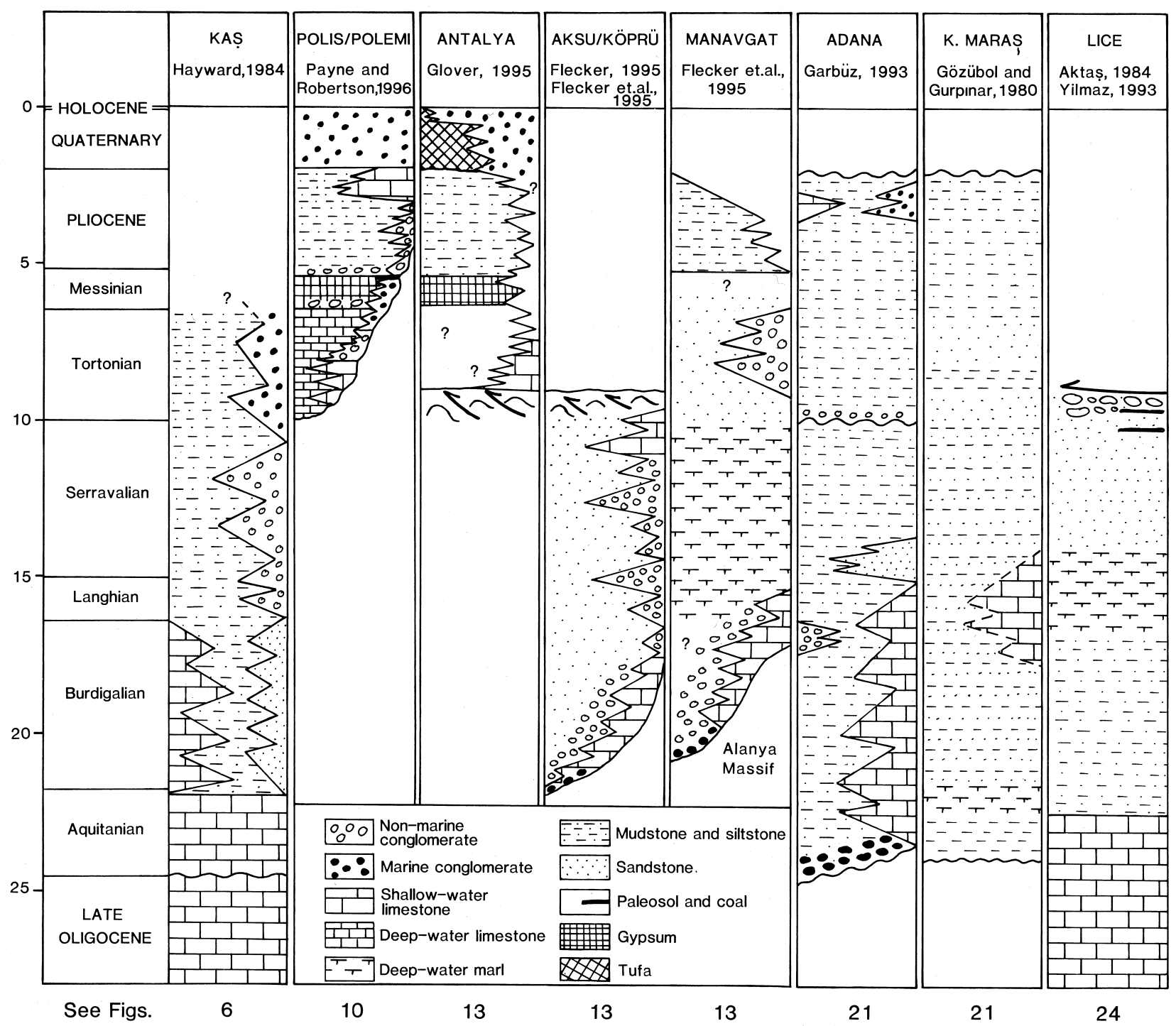

Figure 22. Summary of the onshore Miocene successions in southwestern, southern, and southeastern Turkey. See text for explanation and data sources. Locations on maps in this paper are indicated.

tends northeastward into the Andirın Range (Fig. 21) and the two areas need to be considered together (Misis-Andirın Complex). The Misis Mountains and parts of the Andırın Range are dominated by the Misis-Andırın Complex, for which very different names and origins have been proposed (Schiettecatte, 1971; Kelling et al., 1987; Karig and Közlü, 1990).

The lower part of the Misis-Andirın Complex, well exposed in the Misis Mountains, is dominated by distal volcanogenic turbidites (Karataş Formation) of late lower Miocene to latest middle Miocene age (Kelling et al., 1987; Gökçen et al., 1988). The tectonically overlying upper part of the Misis Complex is a mélange (Isali Formation) containing numerous exotic blocks up to several hundred meters in size ("olistostromes" of Schiettecatte, 1971), embedded in calcareous claystone of locally upper Oligocene-earliest Miocene age, as dated by planktonic foraminifers and ostracodes (Gökçen et al., 1991). Blocks include ?Paleozoic limestone, Mesozoic-lower Tertiary limestones, ophiolitic rocks (serpentine, gabbros, pillow lava), volcaniclastic, and radiolarian sediments (Schiettecatte, 1971).

Abundant volcaniclastic sediments forming "olistoliths" within the mélange include very disrupted units of massive volcaniclastics, thinner bedded volcaniclastics, and more coherent successions of thin-bedded turbidites (Karataș Formation). Geochemical studies involving stable-trace element analysis indicate that two types of volcanic rock are present: (1) evolved volcanics and siliceous tuffs of calc-alkaline composition, presumably erupted from a contemporaneous volcanic arc. Fresh tuffaceous sediments are specifically seen in the upper part of the Isali Formation and in the overlying Karataș Formation (Yetiş et al., 1995), and (2) basic volcanic rocks that appear on geochemical grounds to have been erupted above a subduction zone. Floyd et al. (1992) suggested that all these volcanic rocks formed in a Miocene volcanic arc and a related rifted back-arc basin. The tuffaceous volcaniclastic sediments within deep-water turbidites were derived from coeval arc volcanoes.

The mélange was initially interpreted as an olistostrome related to south-eastward sliding of heterogeneous blocks into a sedimentary basin (Isali Formation). This was later emplaced over, or against deep-water Miocene volcanogenic turbidites to the south (Karataș Formation). The setting of this deposition was the northern margin, within the northern margin of the Iskenderun basin in Pliocene-Pleistocene time (Schiettecatte, 1971; Fig. 21). Kelling et al. (1987) regarded the mélange as olistostromes, shed into a compressional foredeep (related to southward thrusting) within an overall fore-arc or 

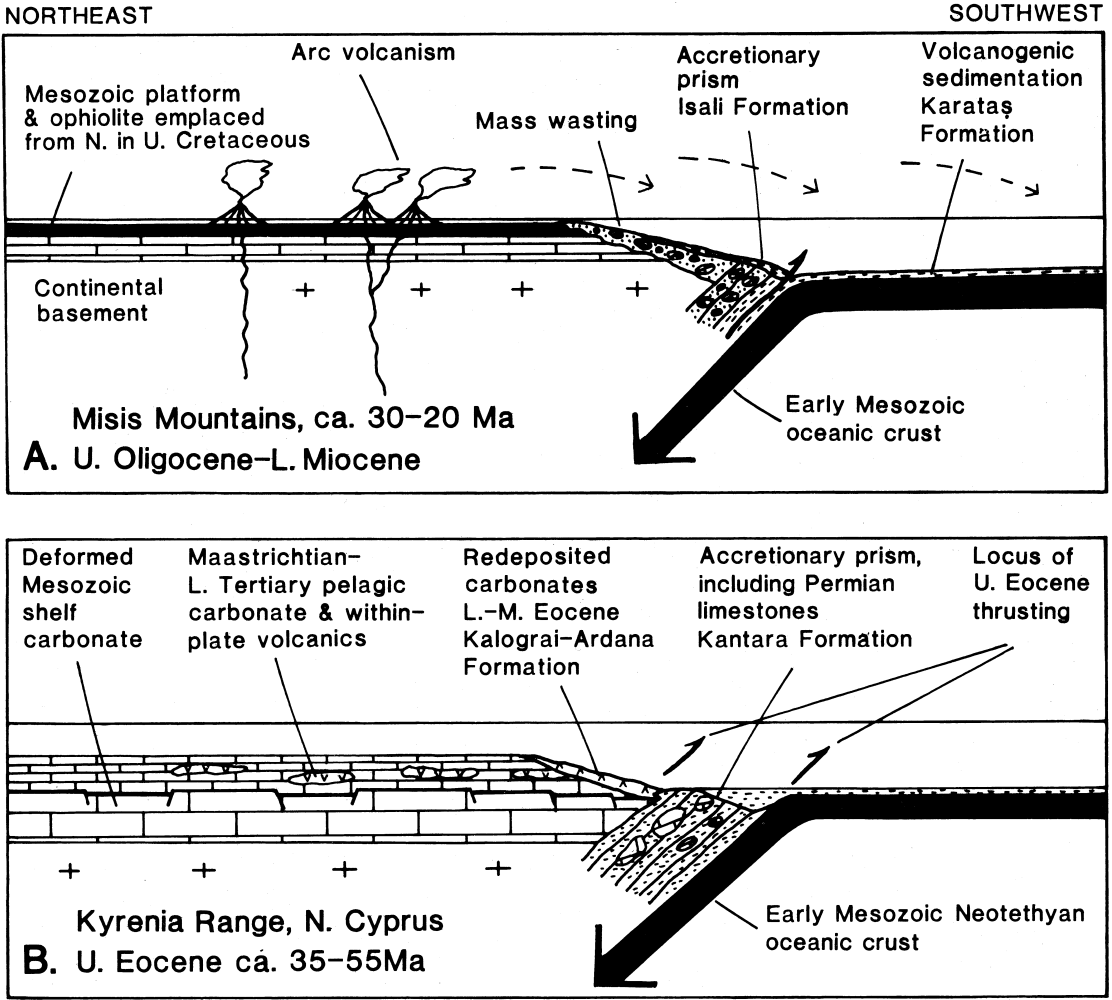

Figure 23. Tectonic models for contrasting mélanges in the easternmost Mediterranean. A. Late Oligoceneearly Miocene mélange in the Misis Mountains, southern Turkey (Misis-Andırın Complex). B. Early-middle Eocene mélange in the Kyrenia Range, northern Cyprus. C. Late Cretaceous mélange on the Arabian margin in southeastern Turkey. See text for explanation.

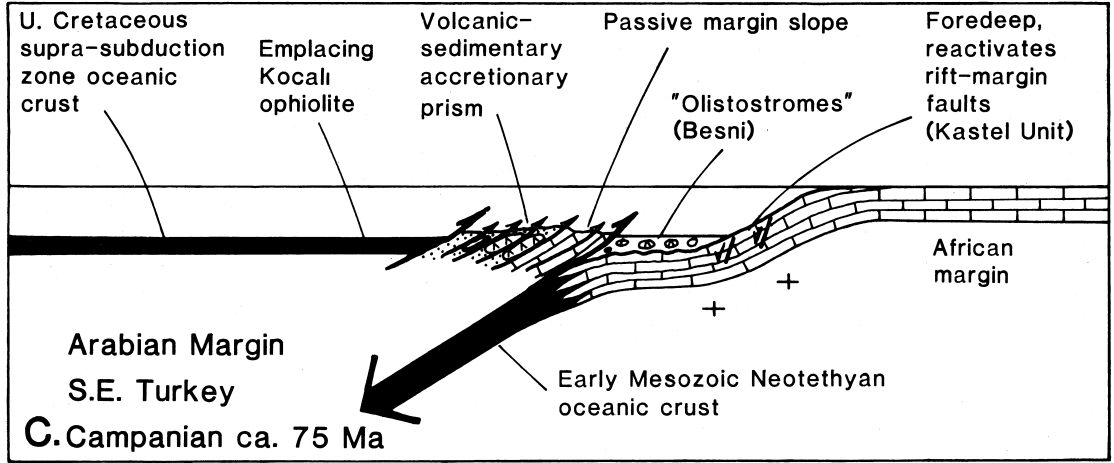

backarc setting. The mélange was later deformed in a transpressional setting, while transtension prevailed further southwest. An alternative interpretation of the mélange is that it formed as a subductionaccretion complex (rather than simply a foreland basin), as shown in Fig. 23A.

A very different view emerged from a study of the Andirın Range, along strike to the northeast (Karig and Közlü, 1990; Fig. 21). The Misis-Andırın Block exposes units including Upper Cretaceous carbonates, Eocene, mafic flows, agglomerates and volcaniclastics, bioclastic and argillaceous limestones, Eocene-Oligocene? hemipelagic silty marls, calcarenites, calcilutites, and localized mass-flow units of late Oligocene age. The assemblage thus appears to be more complete than that exposed in the Misis Mountains to the southwest (i.e., Aslantaş Formation).

The tectonic contact between the upper and lower units of the Misis-Andırın Complex was mapped by Karig and Közlü (1990) as a regionally important extensional fault (Aslantaș Fault Zone, Fig. 21) that separates mainly Mesozoic basement units of the Andırın Range to the north from the Iskenderun Basin and an extensional counterpart, the Aslantaş-Iskenderun Basin to the southeast (Fig. 21). The Misis-Andirin Complex) is interpreted as a late Oligocene to middle Miocene half-graben rather than related to a compressional foreland setting. Karig and Közlü (1990) argue that final emplacement of regionally important allochthonous units in this area took place before the Miocene, followed by opening of a transtensional basin. The mélange is thus related to extensional detachment faulting in this model. More data are needed to test this hypothesis. However, an extensional origin is not in keeping with the evidence of regional convergence of the African-Eurasian plates and related thrusting in southeastern Turkey and the Zagros Mountains during the Miocene.

After the late Miocene initiation of the East Anatolian Fault (Şengör et al., 1985), the northern boundary of the Aslantaş-Iskenderun Basin switched to partitioned compression and strike slip in Pliocene time, according to Karig and Közlü (1990). Older thrust faults (e.g., in the Misis Mountains) were sealed by late Pliocene and Pleistocene sediments and volcanics, whereas fault patterns suggest a most recent switch to extension, or transtension. The timing of late Miocene-early Pliocene, inferred, transpression onshore predates the initial uplift of the Kyrenia Range in Cyprus in late Pliocene-early Pleistocene.

\section{Miocene Subduction-Related Events}

Both the Adana Basin and the Kyrenia Range show evidence of marked subsidence in the late Oligocene-early Miocene, at the same 
time as large-scale mass flow in the Misis Mountains and the Andırın Range. No equivalent of the Miocene Misis-Andirın Complex is known in the Kyrenia Range. Possibly it exists, but is concealed by downfaulting along the southern margin of the range. Regional subsidence was either caused by southward compression and thrusting to form a foredeep (Williams et al., 1995), or by regional crustal extension and detachment faulting (Karig and Közlü, 1990). In the former setting, thrusting would represent locally continued southward advance of the deformation front associated with the Africa-Eurasia plate boundary, whereas, in the second, it could record southward retreat ("roll-back") of a trench in which remaining Neotethyan oceanic crust was being subducted. The two processes are not necessarily mutually exclusive. In a comparative area, the Ionian Zone of northwestern Greece and offshore areas, westward thrusting of the thrust sheets derived from the Neotethyan Pindos ocean to the east has continued into Pliocene-Pleistocene time (Underhill, 1989). The Ionian Zone is underlain by a eastward-dipping subduction zone that may date from the Oligocene. Structures in this Greek area thus reflect both thrust loading from the east and extensional roll-back toward the west and a similar dual influence may apply to the Kyrenia-Misis area. Specifically, regional convergence was partly adsorbed by crustal shortening to the north, and subduction "roll-back" to the south, explaining why the Adana Basin shows some features akin to a foreland basin, but without evidence of a preserved thrust load.

Floyd et al. (1995) invoked a mature volcanic arc to back-arc basin couple in the late Oligocene-Miocene within the Misis-Andırın Complex. Large areas of oceanic crust would necessarily have remained in the easternmost Mediterranean to fuel this arc volcanism and backarc rifting. The interpretation is very questionable as: (1) the coarse volcaniclastic material is either as olistoliths, or detrital and is not itself dated as Oligocene-Miocene; (2) no intact exposures of Miocene mature arc or backarc basins are known regionally. Indeed, much of the volcaniclastic sediment in the Misis-Andirın Complex was probably reworked from earlier units, that could include tuffaceous Eocene mafic extrusives, or Upper Cretaceous ophiolitic rocks. On the other hand, primary eruptive tuffs do occur, in the lower unit of the Misis-Andırın Complex (Karataş Formation), and in the Tortonian interval of, both the Adana Basin (Kuzgun Formation; Yetiş et al., 1995), and the Kithrea Flysch, northern Cyprus (Weiler, 1965; Baroz, 1979; Robertson and Woodcock, 1986). This evidence confirms that some calc-alkaline volcanism of Miocene age did occur in the easternmost Mediterranean area, implying coeval subduction. However, the Miocene volcanism was probably limited and did not extend to genesis of oceanic crust by back-arc rifting, since by this time too little oceanic crust remained in the easternmost Mediterranean to fuel arc rifting and back-arc spreading.

The following model is proposed (Fig. 23A). Exotic rocks, including Upper Cretaceous ophiolites, were regionally emplaced southward from a more northerly Neotethyan ocean basin ("Inner Tauride Ocean") onto a Mesozoic carbonate platform. This formed part of the northern margin of the southern Neotethyan oceanic basin, before the Oligocene. Thrust sheets were emplaced southward in late Eocene time, related to final closure of the "Inner Tauride Ocean" to the north. Continuing plate convergence was accommodated by crustal thickening in the north (possibly manifested in blind thrusting within basement), coupled with subduction of Neotethyan oceanic crust to the south, along a northward-dipping subduction zone located to the south of the Kyrenia Range. This subduction gave rise to the late Eocene "olistostromes" in the Kyrenia Range (Fig. 23B).

In response to continuing Africa-Eurasia convergence, northward-dipping subduction was active in late Oligocene-early Miocene time as evidenced in the Misis-Andirın Range. Deep-water volcanogenic sediments accumulated in a remnant Neotethyan oceanic basin to the south (Karataş Formation, Fig. 23A). The sedimentary mélange (Isali Formation) is interpreted as a subduction trench deposit. Platform carbonates, ophiolitic and older arc rocks collapsed into the trench, as olistoliths. Sufficient subduction continued during the
Miocene to fuel local arc volcanism. The trench migrated southward to near its final position, south of Cyprus, by the start of the Miocene. Localized compression and southward thrusting in southern Cyprus (Yerasa Fold-and-Thrust Belt; Fig. 9) in the early Miocene was possibly related to initiation of this latest subduction zone.

\section{SEGMENT 4: LEVANT-SOUTHEASTERN TURKEY Arabian Margin}

The final segment to be discussed (Fig. 5) extends northward from the Precambrian basement of the Negev, along the north Arabian margin into southeastern Turkey.

The coastal plain of the Levant is dominated by thick PliocenePleistocene sediments, mainly loess. The continental margin of the Levant underwent uplift in the Miocene, contemporaneous with initiation of the Dead Sea transform system (Girdler, 1986; Makris and Henke, 1992). Before this time, the northern and central Negev were dominated by a carbonate platform that extended far across the Arabian continental margin (Gvirtzman, 1990, 1993). The interval between the middle and late Eocene was marked by a tectonically triggered depositional hiatus that is attributed to progressive closure of the Neotethys ocean, although final collision and suturing did not take place until the Miocene in eastern Turkey. During the Late Cretaceous, nutrient upwelling took place in a bathyal setting, giving rise to extensive phosphatic and siliceous deposits (Almogi-Labin et al., 1991). During the mid-Cretaceous, a regional transgression occurred, giving rise to mainly pelagic sedimentation, from Eocene to Coniacian (Garfunkel and Derin, 1984, Garfunkel, 1987, 1988). The effects of this transgression are also recorded in offshore areas (Mart, 1994; Mart and Robertson, Chap. 52, this volume).

The earlier Mesozoic record is dominated by shallow-marine limestones, dolomites, marls, shales, sandstones, and minor evaporites, typical of a continental shelf setting. Basic volcanic centers of Early Cretaceous age in the Negev were previously interpreted, alternatively: (1) as evidence of rifting to form a Cretaceous Neotethys (Dercourt et al., 1986), (2) related to southward-subduction from Neotethys to the north (Freund et al., 1975), or (3) to intraplate volcanism (Garfunkel, 1989). Recently, a rift-related origin has received support (Laws and Wilson, 1996). The southern Levant is dominated by Panafrican basement, with a variable Paleozoic sedimentary cover, that is assumed to extend northward beneath the Arabian platform carbonates.

The structure of the Levant west of the Dead Sea transform fault (Figs. 6, 20) is dominated by a chain of asymmetric anticlines and synclines, termed the "Syrian Arc." This feature extends from northern Sinai to southern Syria, over an $\sim 150 \mathrm{~km}$-wide zone, over a length of $\sim 1000 \mathrm{~km}$. Individual anticlines are typically $30 \mathrm{~km}$ wide and about 1500-2500 $\mathrm{m}$ in structural relief. Studies of seismic and borehole data (Cohen et al., 1990) reveal that the Syrian arc structures originated as extensional faults along the Permo-Triassic rifted margin of the Levant (Garfunkel and Derin, 1984; Cohen et al., 1990). These faults were dormant during the Mesozoic passive margin phase, but were reactivated and progressively inverted during the Late Cretaceous and Eocene. The compression that gave rise to the Syrian arc probably also affected the adjacent Levantine Basin, including the Eratosthenes Seamount.

Late Cretaceous inversion of the Syrian arc structures is generally assumed to relate to the emplacement of ophiolites onto the northern margin of the Arabian plate (Şengör and Yilmaz, 1981; Yazgan, 1984; Yilmaz, 1991, 1993). Shallow-water carbonate platform deposition ended in the Coniacian, followed, later in the Late Cretaceous, by subsidence to form a foredeep that filled with "olistostromes" before overthrusting by dismembered thrust sheets of Mesozoic passive continental margin and ophiolitic units. In northern Syria, discontinuous platform sedimentation continued into the lower Maastrichtian, followed by generally southward emplacement of allochthonous 


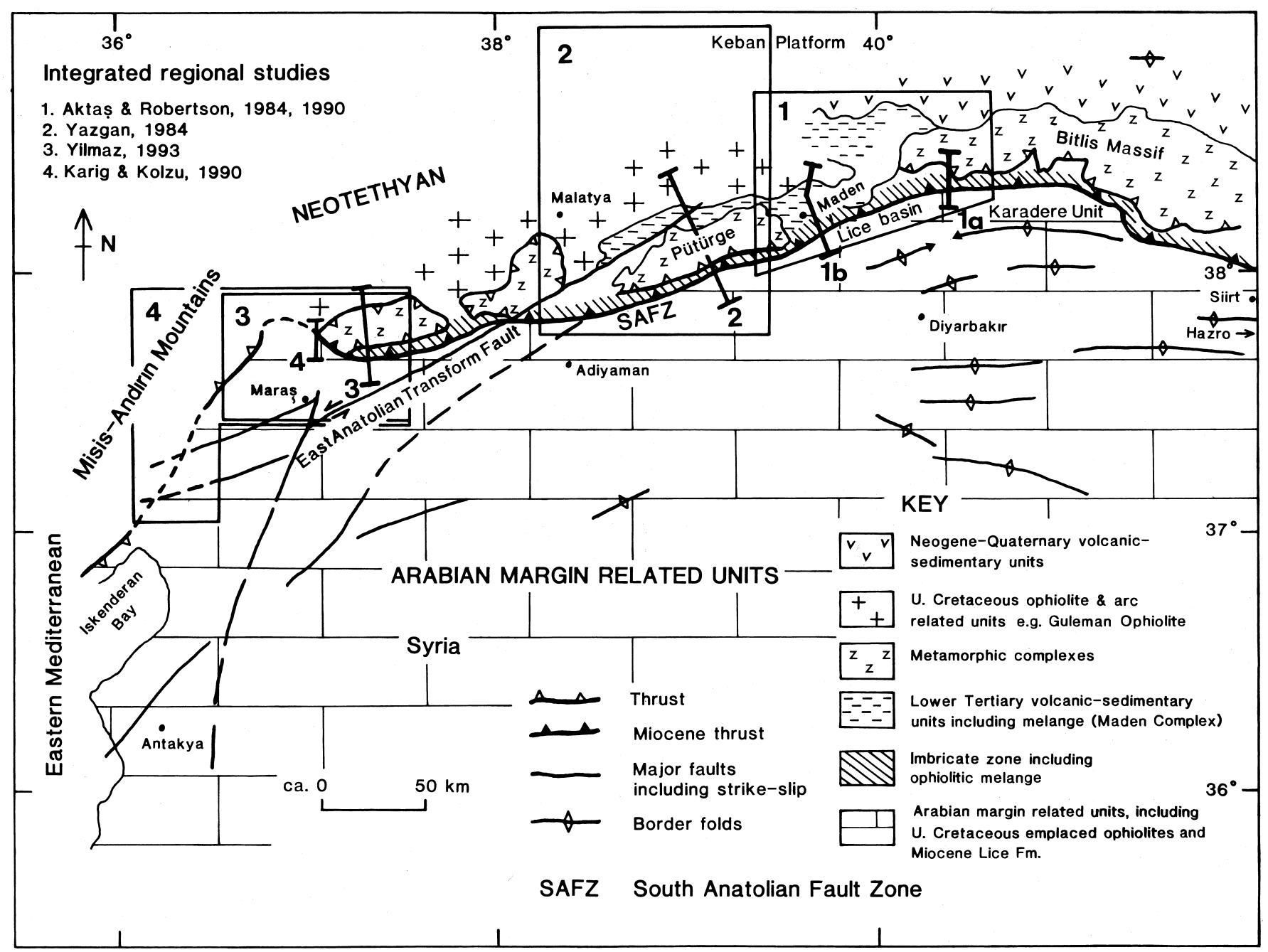

Figure 24. Outline tectonic sketch map of the main units in southeast Turkey. Cross sections are given in Figure 25. Map based on 1:200,000 geological map of Turkey. See text for explanation and data sources.

units. These comprise Upper Cretaceous ophiolites, of supra-subduction zone type, similar to the Troodos ophiolite (Delaloye et al., 1980; Delaloye and Wagner, 1989; Dilek et al., 1991; Pişkin et al., 1986; Dilek and Delaloye, 1992). The emplaced ophiolite represents relatively intact oceanic lithosphere in Hatay (southern Turkey; Fig. 21), but the ophiolite was severely dismembered during emplacement in the Baer-Bassit and Kurd Dagh areas (in northern Syria). The BaerBassit ophiolite is tectonically underlain by deformed thrust sheets of deep water sedimentary and volcanic rocks of late Triassic to Cenomanian age that are interpreted as the emplaced northern margin of the Arabian plate (Delaune-Mayere et al., 1977). In Hatay the ophiolite is transgressed by upper Cenomanian-early Maastrichtian aged fluvial clastics, then shallow marine sediments, whereas in Baer-Bassit the oldest marine transgressive sediments are of late Maastrichtian age, in northern Syria (Delaune-Mayere et al., 1977; Delaloye and Wagner, 1984).

Collision of ophiolite-related units with the Arabian passive margin is an obvious possible cause of inversion of the Syrian arc further south. Ophiolite obduction onto the Arabian margin was completed in Hatay before the upper Campanian-early Maastrichtian. However, a submerged anticline (Litani anticline) off the northern Israel coast, regarded as a submerged offshore part of the Syrian arc (Mart, 1994), is interpreted as having been folded in the Turonian, and then unconformably overlain by undeformed Late Cretaceous (Senonian) and
Tertiary strata. The implication is that initial inversion of the Syrian arc may predate ophiolite obduction onto the Arabian platform. One possibility is that the inversion dates the initiation of northward subduction within Neotethys (that gave rise to the Troodos, Hatay, BaerBassit ophiolites by supra-subduction zone spreading). Stress was transmitted toward the continent through dense oceanic crust and reactivated rift-related structures on the Arabian margin. Similarly, the Eocene inversion of the Syrian arc reflects southward stress propagation that marks convergence, and the initial stages of collision. However, this predates actual suturing of the Eurasian and Arabian plates in southeastern Turkey that was not complete until the Miocene (see below). After the Dead Sea transform system became active in the Miocene, movements along the Syrian arc largely ceased.

\section{Southeast Turkey}

Further evidence for Late Cretaceous deformation and emplacement of ophiolites onto the Arabian margin comes from southeast Turkey (Fig. 24). This region is divided into two fundamentally different units by the regionally extensive South Anatolian Fault Zone. Units to the south form part of the Arabian continental margin, while those to the north of this fault zone include various allochthonous Neotethyan-related units. The South Anatolian Fault Zone was generally interpreted as a major regional thrust of allochthonous Neo- 
tethyan units over the Arabian margin. However, Karig and Közlü (1990) re-interpreted the westward continuation of this fault zone into the Misis-Andirın region (Fig. 24) as a strike-slip fault that was reactivated by late-stage, post-Miocene compression. In view of these alternatives, the non-genetic term South Anatolian Fault Zone is used here. However, a thrust-related origin fits the evidence from southeastern Turkey. In addition, southeastern Turkey as a whole is transected by the Pliocene-Pleistocene East Anatolian Transform Fault. Displacement remains poorly constrained $(<25 \mathrm{~km}$; see Şengör et al., 1985), precise correlations of units on either side have not been confirmed.

From east to west the Arabian margin in southeast Turkey shows considerable facies variation during the Miocene related to diachronous overthrusting of allochthonous units. In the east (north of Diyarbakir), turbidites accumulated in a foreland basin in the Early Miocene (Fig. 24), ranging from proximal in the north (Cüngüs Formation) to more distal in the south (Lice Formation). In the west (Maras area), clastic sediments were shed westward into a basin open to the west in the mid-Miocene. There is evidence of a minor transgression in the Langhian. During the early Miocene (Burdigalian), the basin was wider, receiving clastic input from the east, whereas the northern margin was bordered by a narrow carbonate shelf, and basalts, basaltic andesites (associated with tuffaceous sediments) were erupted in the south (Derman et al., 1996). The overall pattern is one of westward migrating diachronous collision. The volcanism could relate to bending and disruption of the downgoing slab as it approached the collision zone.

Throughout southeast Turkey, the Miocene clastic successions are underlain by muddy calcareous sediments ( 1000 m thick), of Oligocene age that are interpreted to have accumulated on an unstable shelf before suturing of Neotethys. The base of this succession unconformably overlies ophiolites that were emplaced in the Late Cretaceous.

The initial stages of southward obduction of the ophiolites resulted in subsidence of the Arabian platform and incoming of Maastrichtian terrigenous sediments (Righo di Righi and Cortesini, 1964; Yilmaz, 1993). This unit is tectonically overlain by sedimentary mélange (i.e., "olistostromes"), then by tectonic mélange, and finally by large ophiolite thrust slices. The Maastrichtian basin is interpreted as a foredeep related to ophiolite emplacement, as inferred for a similar unit, the Muti Formation, in Oman (Robertson, 1987). The tectonic mélange contains Late Triassic to Late Cretaceous units (Fourcade et al., 1991) and is interpreted as emplaced remnants of the former deep-water passive margin of the Arabian plate. It is, for example, comparable with the para-autochthonous Sumeini slope carbonates in Oman (Watts and Garrison, 1979). This mélange includes blocks of Permian and Triassic mafic volcanics, limestone, radiolarite, and serpentinite, set in a mainly pelitic matrix. Volcanics and neritic limestones can be correlated with the Oman exotics, representing obducted oceanic seamounts (e.g., Searle and Graham, 1982). The mélange is here interpreted as a subduction-accretion complex related to northward subduction of Neotethyan oceanic crust in the Late Cretaceous, before its emplacement onto the Arabian margin to the south (Fig. 23C). In southeastern Turkey the overlying ophiolites (e.g., Kocali) are smaller and less well exposed than counterparts further west, such as the Hatay ophiolite.

Mesozoic time saw construction of a substantial carbonate platform along the southern margin of the Neotethyan ocean in a passive margin setting. Beneath are Paleozoic shelf-type successions, inferred to have accumulated along the northern margin of Gondwana (as exposed in the Hazro Inlier; Fig. 24; Fourcade et al., 1991).

\section{Northern Margin Units}

Understanding the geological history of the structurally overlying allochthonous units to the north of the South Anatolian Fault Zone is complicated by the different names used for often-similar units in ad- jacent areas studied in the field by various workers. However, a relatively small number of major grossly allochthonous tectonostratigraphic units are present to the north of the South Anatolian Fault Zone (Fig. 24).

1. Metamorphic complexes: The most obvious of these units are large metamorphic complexes, of which the Bitlis and Pütürge Massifs are the best known (Fig. 24). A poly-metamorphic origin is generally accepted (Helvaci, 1984), including metamorphosed equivalents of the Late Triassic volcanic-sedimentary units related to continental breakup (Perincek, 1979; Perincek and Ozkaya, 1981). The metamorphics are intruded by granitic rocks (e.g., in the BitlisPütürge Massifs and Keban Platform (Fig. 24), dated at 85-76 Ma and Campanian-Maastrichtian), and assumed to document Late Cretaceous Andean-type magmatism. The Pütürge metamorphic massif is depositionally overlain by early Tertiary-middle Eocene shallowwater carbonates (Yazgan and Chessex, 1991), passing up into deeper water volcanic-sedimentary units (Bingöl, 1990; Hempton, 1984).

One school of thought is that the metamorphic massifs represent the northernmost extension of the (unexposed) metamorphic basement of the Arabian margin to the south (Yazgan, 1984; Yazgan and Chessex, 1991). However, most workers regard these metamorphic rocks as one, or several, continental fragments rifted from Gondwana in the Triassic, associated with opening of a southerly Neotethyan oceanic basin (Hall, 1976; Şengör and Yilmaz, 1981; Robertson and Dixon, 1984; Yilmaz, 1993).

2. Ophiolite and arc units: A second major unit north of the south Anatolian Fault Zone is made up of remnants of mainly Late Cretaceous ophiolitic- and arc-related units, known by different names in different areas (e.g., Yuksekova arc, Başkil arc, Guleman ophiolite, İspendere ophiolite; Fig. 25). Exposures are most extensive in the area north of, and between, the Bitlis and Pütürge metamorphic massifs (Fig. 24). One of the largest of these ophiolitic units is the Guleman ophiolite, which, however, lacks an intact volcanic-sedimentary cover. Adjacent to this, and probably contiguous with it, is the large İspendere ophiolite, which includes Upper Cretaceous arc-type intrusives (Yagzan, 1984). In addition, small slices of ophiolitic rocks are found structurally underlying the Bitlis and Pütürge metamorphic massifs, and similar ophiolite slices are thrust-intercalated with an early Tertiary volcanic-sedimentary unit, known as the Maden Complex (Aktaş and Robertson, 1984; Figs. 25-1B, -2; see below).

3. Volcanic-sedimentary units: A third major unit is the Maden Complex, or Maden Group. The Maden Complex is a composite tectono-stratigraphic unit, that was defined by Aktas and Robertson (1984, 1990a, 1990b), based on study of the type area (near Maden town, Fig. 24), as "late Mesozoic ophiolitic rocks and Tertiary sediments, tectonic mélange and mafic volcanics...." The term has been used for a variety of volcanic-sedimentary successions of mainly early Tertiary age (locally with Late Cretaceous inclusions) in different areas and structural positions. Some of these are intact stratigraphic units, for which Maden Group is the preferred term, whereas others units are highly dismembered (mélange) for which the term Maden Complex is appropriate.

For example, along the northern margin of the Pütürge metamorphic massif, a deformed, but originally coherent, volcanic-sedimentary unit of middle Eocene age is exposed (Maden Group; Hempton, 1984; Fig. 25-1B, -2). Farther east, relatively undeformed sediments of Maastrichtian to middle Eocene age unconformably overlie an Upper Cretaceous ophiolite (Guleman ophiolite) and related units in the area between the Bitlis and Pütürge metamorphic massifs (Fig. 25-1A; Hazar Group of Aktaş and Robertson, 1990; Fig. 24). These latter sediments can be interpreted in part as proximal facies equivalents of middle Eocene mainly deeper-water facies described by Hempton (1984).

In the north, the northern margin of the Pütürge metamorphic massif is transgressed by shallow-water limestones (Maden Group; Fig. 25-2) that pass upward into an intensely thrust-imbricated and sheared unit of deep-sea argillaceous and volcanogenic sediment 


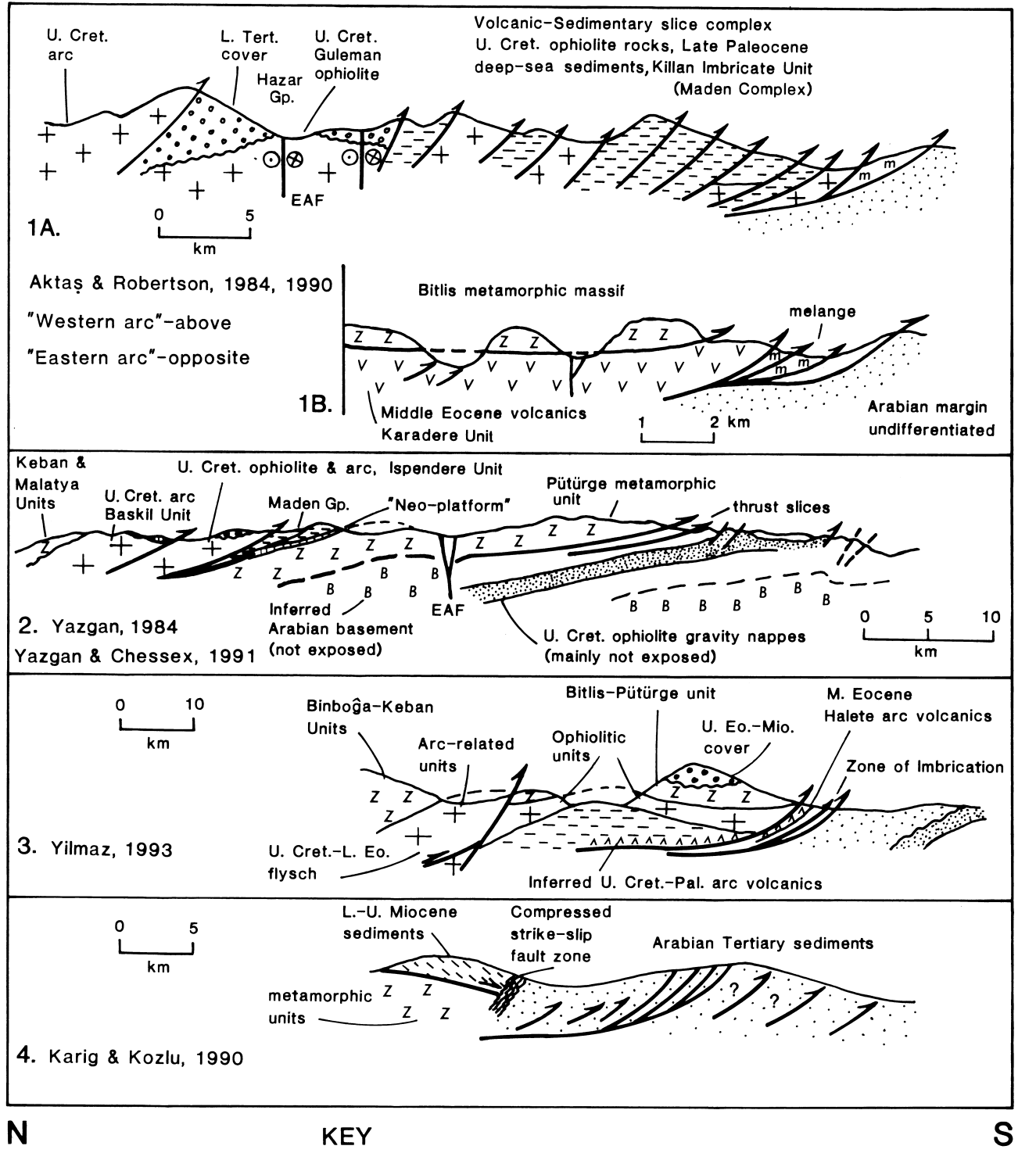
$\therefore: \because$
L.-U. Miocene sediments on metamorphics, 4
\begin{tabular}{lll}
\hline & $z$ \\
\hline
\end{tabular}
Metamorphic Units, 1-4
$++$
U. Cretaceous (mainly) ophiolite-related arc units, 1-3
WIII
"Neo-platform" units, 2
$\begin{array}{rll}0 & 0 & 0\end{array}$
L. Tertiary cover units, 1-3
$\overline{z-z-}$
L. Tertiary imbricated deep-sea sediment \& volcanogenic units, 1-3
$\hat{\wedge} \wedge \hat{\wedge} \wedge$
U. Cretaceous-Paleocene arc volcanics (conjectural), 3

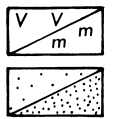
Middle Eocene volcanics in slice complex/melange $(\mathrm{m}), 1$
Arabian margin units, including ophiolite. Undifferentiated except for ophiolite (dense stipple), 1-4

Figure 25. Simplified cross sections across Neotethyan allochthonous units in southeast Turkey. See text for explanation and data sources; locations are on Figure 24. 
(Hempton, 1984). Further west, in the Maraș area (Fig. 24). Yilmaz (1993) reported similar Eocene lithologies depositionally overlying Upper Cretaceous ophiolitic rocks in both southerly and northerly areas. (However, on his published cross section the contact is shown as tectonic and the unit does not appear on maps given [his fig. 2a]). Yilmaz (1993) used evidence that both the ophiolitic and metamorphic units are unconformably overlain by similar middle Eocene sediments to argue that both units were structurally juxtaposed before the middle Eocene.

Yilmaz (1993) also reported a small ( $\sim \mathrm{km}$ wide) tectonic window of deep-sea, radiolarian and volcanogenic sediments of middle Eocene age beneath a large thrust sheet of metamorphosed ophiolite in the westerly Maraş area (Fig. 25-3). This relationship is crucial, as it was taken to imply that the metamorphic units were emplaced over the Maden Group sediments after deposition in the middle Eocene.

In the type area (i.e., near Maden town, Fig. 24) the Maden Complex is an $\sim 17-\mathrm{km}$-thick imbricate slice complex, made up of thrust sheets and mélange composed of Upper Cretaceous ophiolitic rocks (basalts, intrusives, and serpentinite), intercalated with deep-sea argillaceous, calcareous, and volcanogenic sediments (Fig. 25-1A). The oldest recorded age of syntectonic sediments is earliest late $\mathrm{Pa}$ leocene in age (Aktaş and Robertson, 1990). This unit is inferred to have formed originally further south that the coherent Eocene successions of the Maden Group mentioned above.

4. Eocene volcanics: A fourth important unit is known structurally beneath the Bitlis metamorphic massif, both in the west (Karadere area) and in the east (Siirt area, Fig. 24). This unit is a substantial thrust sheet (up to $2 \mathrm{~km}$ thick) composed of subalkaline mafic volcanics interbedded with terrigenous turbidites and depositionally overlain by pelagic carbonates of middle Eocene age (Karadere Formation) (Aktaş and Robertson, 1984; Fig. 25-1B). This unit was included within the Maden Complex by Aktaş and Robertson (1984), but is better recognized as a separate tectonic unit, termed the Karadere Unit, in view of its distinctive features.

The volcanics of the Karadere Unit vary considerably within a single thrust sheet and include high Ti, high-Al, and evolved basalts (Aktaş and Robertson, 1990a). Trace-element geochemical data reveal a subduction-zone imprint, but also imply the existence of an associated enriched source to explain the diverse lava types. A possible setting for eruption of these volcanics is an above-subduction zone marginal basin, that included seamounts, similar to the Bransfield Straits in Antarctica (Weaver et al., 1977). However, such a setting might be discounted in view of the absence of coeval arc volcanics or tuffaceous sediments within the Karadere unit. Aktaș and Robertson (1990a) instead favored formation in a transtensional pull-apart basin setting during the initial stages of collision of Arabian and Eurasian units. The subduction influence was seen as inherited from earlier Late Cretaceous subduction in the area. The pull-apart basin developed during oblique convergence of the African and Eurasian plates before complete collision.

5. Disrupted thrust sheets and mélange: A final important unit is a zone of imbricate thrust sheets and mélange located at the lowest structural levels, above the Miocene Arabian margin (Lice Formation, Fig. 24). Highly dismembered ophiolitic rocks and tectonic mélange predominate, with an estimated structural thickness of $25 \mathrm{~km}$ (Killan Unit). This mélange includes highly dismembered equivalents of structurally overlying units within the type area of the Maden Complex (Aktaș and Robertson, 1984). At two localities, ophiolitic basalt blocks contain radiolarians of Late Cretaceous age (Aktaş, 1985; Fig. 25-1A, -1B).

Recently, Yilmaz (1993) reported an additional important unit of Eocene age at a similar structural level in the west (near Maraș; Halete Volcanics; Fig. 25-4). This unit forms a laterally continuous (>20 $\mathrm{km}$ ) thrust sheet up to several kilometers thick that is tectonically intercalated with chaotic late Eocene-Oligocene sediments below, and an ophiolitic unit above within an overall "zone of imbrication." The
Halete unit is composed of middle to upper Eocene andesite and associated pyroclastic rocks, with interbeds of reef limestone near the top of the succession (Yilmaz, 1993). Eocene volcanics were also noted by Karig and Közlü (1990) within their Misis-Andırın unit (Fig. 24).

Yilmaz (1993) interpreted the Halete volcanic unit as an Eocene volcanic arc related to the later stages of northward subduction of the Neotethyan ocean, before collision and final thrusting over the Arabian margin along a South Anatolian basal thrust. This is important as it requires that the southerly Neotethys remained sufficiently wide to fuel subduction and back-arc rifting in the Eocene. However, this hypothesis is difficult to evaluate as no geochemical data are given for the volcanics. The Halete volcanics could be equivalent to the middle Eocene Karadere Unit volcanics further east, or possibly to younger (Paleocene-Eocene) volcanics in the Kyrenia Range of Cyprus. Geochemical evidence from both of these coeval units does not support a simple subduction-related origin.

\section{Alternative Models of Neotethys in Southeastern Turkey}

The tectonostratigraphy of southeastern Turkey is now fairly well known, but controversies persist, particularly concerning the tectonic settings of formation and structural relationships of individual units. Alternative tectonic models are shown in Figures 26 and 27.

The Eastern Bitlis Massif includes blueschists and is structurally underlain by an unmetamorphosed "colored mélange," including ophiolitic rocks and Upper Cretaceous radiolarites. Hall (1976) proposed that formation of blueschists was related to a northwarddipping subduction zone located within a Neotethyan oceanic basin adjacent to the northern margin of Arabia. Based on extensive field mapping of the Pütürge and Bitlis Massifs further west, Perincek (1979) identified evidence of Triassic meta-volcanics, that could relate to rifting of the North African margin. He also gave one of the first detailed interpretations of the Maden Complex, which he interpreted as an Early Tertiary backarc basin, developed above a southward-dipping subduction zone. This view was incorporated in Şengör and Yilmaz's (1981) early plate tectonic model. However, subsequent mapping compiled by Aktaș and Robertson (1984) and Yazgan (1984) showed conclusively that the structural grain was regionally northward-dipping, and it was then generally accepted that any Late Cretaceous-Early Tertiary subduction in the area was northwarddipping.

Accepting that any subduction was northward, the next question is whether ophiolitic rocks above the metamorphic massifs in the north (e.g., Guleman and İspendere ophiolites) could be correlated with smaller slices beneath the Bitlis and Pütürge metamorphic massifs (to the south), and interpreted as remnants of an originally much larger ophiolite thrust sheet that was emplaced southward over the Arabian margin in the Late Cretaceous. A widespread early view was that only one Neotethyan ocean basin existed in eastern Turkey (Michard et al., 1984) and, in keeping with this, Yazgan (1984) correlated the northerly and southerly ophiolites and suggested that they were all derived from north of the metamorphic massifs, which were then seen as regional extensions of the Arabian continental basement. In this model, the Late Cretaceous ophiolites and related arc units formed within the Neotethys (possibly near the southern margin of Eurasia) and were then thrust over the Arabian foreland (i.e., the metamorphic massifs) in the Late Cretaceous (Campanian-Maastrichtian). The Neotethys was then finally closed. Ophiolites beneath the Bitlis-Pütürge and other metamorphic massifs reached their present positions as a result of large-scale rethrusting during tightening of the Neotethyan suture in Eocene time. A possible cause of metamorphism of high-level Neotethyan units (e.g., Triassic volcanics) was the thermal effects of Late Cretaceous overthrusting of hot ophiolitic mantle, represented by the Late Cretaceous ophiolites, some of which ended up on the Arabian foreland in this model (e.g., 


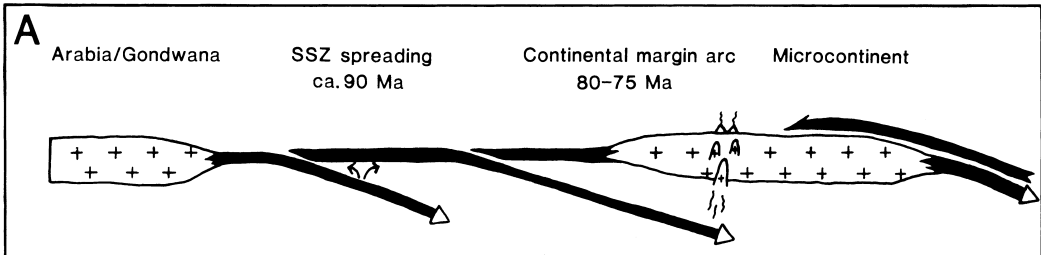

Preferred double subduction zone model

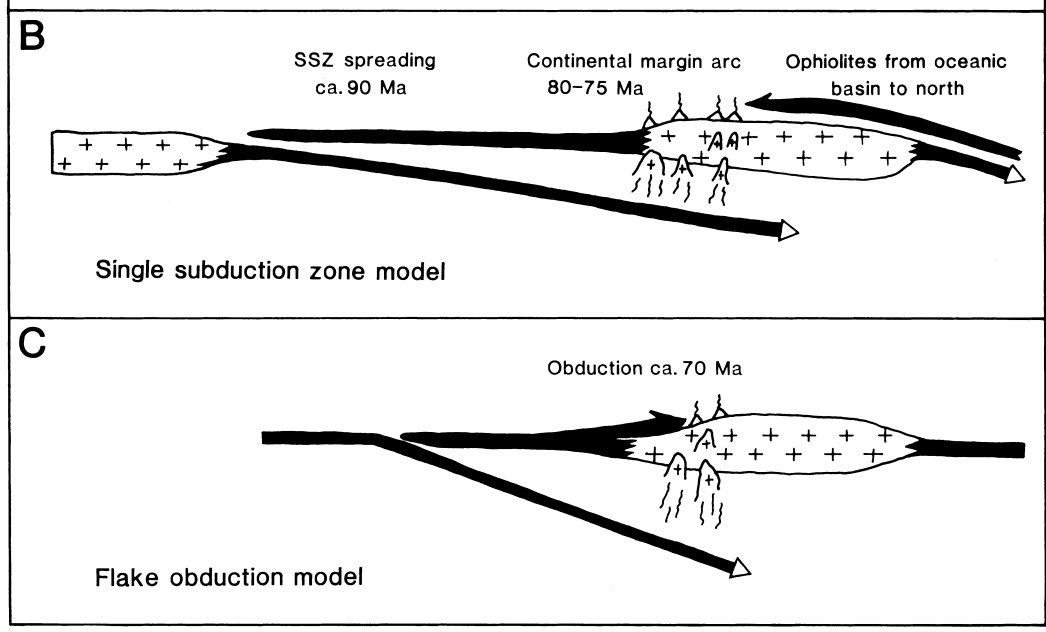

Figure 26. Alternate plate tectonic models for genesis of Late Cretaceous ophiolites. A. Spreading above two subduction zones (i.e., an intra-oceanic one in the south and continental margin one in the south [favored model]). B. A single subduction zone. The main problems are that arc volcanism remained active after collision in the south and little space remained for Tertiary subduction. C. Emplacement of ophiolite from the south as an obducted flake.

Aktaș and Robertson (1990) noted that the Late Cretaceous Ara-

Hatay and Baer-Bassit). Younger extrusives, such as the Eocene Karadere and Halete volcanics, would then have to be of intraplate origin, extensional or transtensional. A number of serious problems exist with the above model of far-travelled thrust sheets: (1) The Arabian foreland does not show any evidence of regional collisional deformation in the Late Cretaceous. As in the Oman Mountains further east, Upper Cretaceous ophiolite emplacement onto the Arabian margin was followed by restoration of a passive continental margin, while the Neotethys remained open to the north (e.g., Gulf of Makran in the Oman case; Lippard et al., 1986; Glennie et al., 1990); (2) Regional metamorphism is very unlikely to relate to ophiolite emplacement, in view of the fact that similar units beneath other ophiolites (e.g., Oman) are unmetamorphosed, with the exception of a thin ( $<100 \mathrm{~m}$ ) dynamothermal metamorphic sole; (3) Mélange units, including the Maden Complex, were viewed as Upper Cretaceous accretionary prisms, but the earliest syntectonic sediments are in fact upper Paleocene (Aktaş and Robertson, 1990), post-dating the time when regional emplacement onto the Arabian margin supposedly took place; (4) The middle Eocene Karadere volcanics differ geochemically from typical intra-plate volcanics.

A southerly Neotethyan oceanic basin instead remained open in southeastern Turkey into the Tertiary. Ophiolites were incorporated into both the northern and southern margins of the Southern Neotethyan oceanic basin in the Late Cretaceous. Were the origin and emplacement of both of these northerly and southerly ophiolitic units genetically linked? Aktaș and Robertson (1984) favored an openocean model, with no direct link between the genesis and emplacement of north- and south-margin ophiolites (Fig. 26A). The early Tertiary Maden Complex (Killan Unit of Maden Complex, Fig. 25-1A) was interpreted as a subduction-accretion complex related to the later stages of closure of the southerly Neotethyan oceanic basin. Limited calc-alkaline volcanics of Eocene age to the north (Basskil unit, Fig. 25-2) suggested to them that significant subduction took place in the early Tertiary. The middle Eocene Karadere volcanics were then seen as pull-apart basins developed in a pre-collisional setting, associated with oblique subduction (Fig. 27G). bian foreland and Late Cretaceous ophiolitic rocks of the overriding thrust sheets are both of supra-subduction zone type, based on geochemical evidence. Rather than inferring two entirely different subduction zones within a small southerly Neotethyan oceanic basin (i.e., one in the south and one in the north) they suggested that only one northward-dipping subduction zone existed in the Late Cretaceous (Fig. 26B). Ophiolites were obducted northward onto the northern margin (e.g., Guleman ophiolite, Fig. 26C); then the leading edge of the supra-subduction zone slab collided with the Arabian margin, temporarily halting subduction. Only a narrow $(\sim 200 \mathrm{~km}$ wide), remnant Neotethyan basin then survived into the Tertiary, and was later consumed by subduction-accretion in the Paleocene-early Eocene. The middle Eocene Karadere volcanics formed by transtensional rifting in a setting of initial oblique continental collision. Collision was complete by Miocene time.

Yilmaz (1993) also adopted a model whereby Upper Cretaceous ophiolites and related metamorphic units were amalgamated by thrusting in the Late Cretaceous, wholly within the Neotethys, well removed from the Arabian margin to the south. The middle Eocene Halete volcanics then represent a subduction-related volcanic arc related to steady-state subduction (Fig. 27H). The Eocene Maden Group sediments would then have formed as a back-arc marginal basin above this northward-dipping subduction zone. The amalgamated ophiolitic and metamorphic units, together, formed the northern margin of the Neotethyan oceanic basin during the Eocene. A relatively wide southerly Neotethyan oceanic basin survived at least into the Eocene. During the early Tertiary, as Africa and Eurasia converged, Neotethyan units to the north (e.g., Keban platform; Fig. 24) were finally amalgamated to the Eurasian margin (within a separate northerly Neotethyan ocean basin to the north), and the deformation front then migrated progressively southward. The compression zone then reached the southerly Neotethyan remnant basin, and the marginal basin later collapsed in the late Eocene-Miocene as it was consumed beneath overriding metamorphic units. In turn, the Eocene Halete arc volcanics were underplated, followed by collision of the fully assem- 


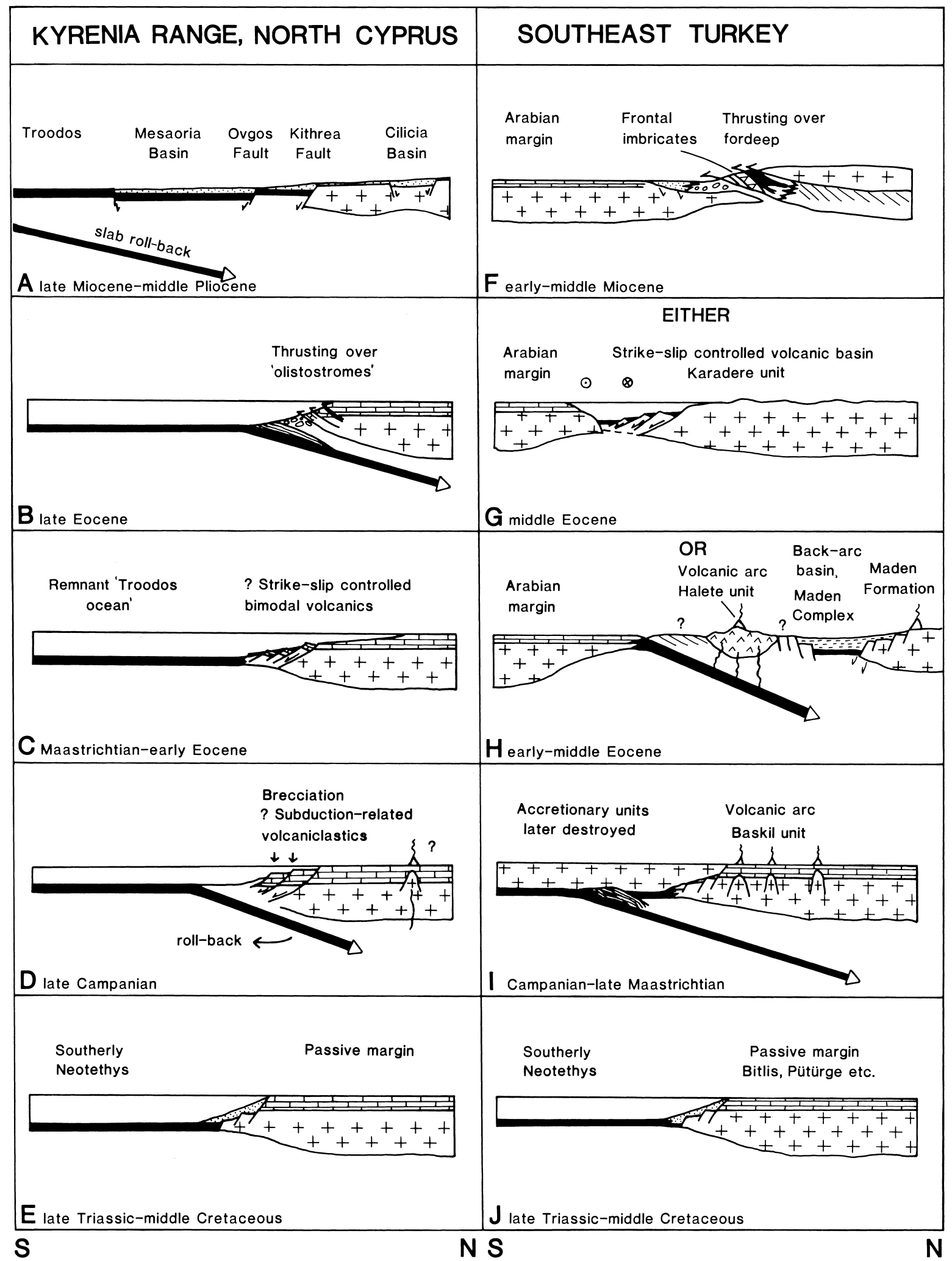

Figure 27. Tectonic model for the Kyrenia Range, northern Cyprus, compared with southeastern Turkey. Both areas formed parts of northern passive margin of Neotethys in easternmost Mediterranean until the late Cretaceous, when convergence was initiated. From the Lower Tertiary onward, collision is more advanced in southeast Turkey than in northern Turkey. Strike-slip (transtension/transpression) is important in the Lower Tertiary. Convergence is complete in southeast Turkey by the late Miocene, whereas subduction occurs south of Cyprus in Neogene time. See text for further explanation. 
bled stack with the Arabian margin in early-late Miocene time (Fig. 27F).

The above model has some attractions. The middle Eocene Karadere volcanics (Fig. 25-1B) are in a similar relative structural position to the coeval Halete volcanics (Fig. 25-3) and could be correlated. The Karadere volcanics would then represent a remnant of an Eocene back-arc marginal basin. There are, however, a number of problems with this model: (1) Detailed field relations and geochemical data for the middle Eocene Halete volcanism are not available and settings other than arc volcanics are possible (e.g., within a pull-apart basin); (2) Yilmaz's (1993) backarc basin is exclusively of middle Eocene age, whereas the oldest syntectonic deep-sea sediments in the type Maden area are of late Paleocene age (Aktaș and Robertson, 1984). Any back-arc basin would thus be longer lived than Middle Eocene; (3) Middle Eocene counterparts farther east (Lice Formation) possess a terrigenous rather than volcanogenic sediment cover; (4) There is evidence of compression of the Arabian margin in the Eocene (Syrian arc), before final Miocene collision (Cohen et al., 1990).

Taking into account evidence from the Kyrenia Range, northern Cyprus, the following model is proposed (Fig. 26A). Ophiolites were emplaced onto the northern margin (i.e., the metamorphic units) of the Neotethyan oceanic basin in the Late Cretaceous. Ophiolites were also emplaced separately onto the Arabian margin, leaving a small Neotethyan oceanic basin surviving into Tertiary time (Fig. 27H). Northward subduction beneath the northern Neotethyan margin then resumed in the late Paleocene-Eocene (Killan unit of Maden Complex), backed by an unstable forearc basin (Hazar Group). A small extensional, volcanic-floored basin (Karadere Unit, Fig. 27G), opened briefly in the middle Eocene along the northerly active continental margin of the remaining southerly Neotethyan ocean basin. Collision of northerly units with the Arabian margin in eastern Turkey began in the late Eocene.The middle Eocene basin then collapsed and was overthrust by metamorphic units. The collision zone migrated westward along the Arabian margin during the Oligocene-Miocene as remaining Neotethyan oceanic crust was consumed. The assembled stack was finally sutured with the Arabian margin (in Eastern Turkey) in the mid-Miocene, preceded by formation of a Miocene flexural basin (Lice Formation; Fig. 27F).

\section{TECTONIC MODEL FOR EVOLUTION OF THE EASTERNMOST MEDITERRANEAN AREA}

In this final section of the paper an attempt is made to integrate the local tectonic interpretations of diverse data sets into a self-consistent model for the tectonic evolution of the easternmost Mediterranean area. The timing of events along both the northern and southern margins of Neotethys in the easternmost Mediterranean is shown in Tables 3,4 .

\section{Late Permian-Late Triassic}

Before Late Permian time, the easternmost Mediterranean area formed part of the northern margin of Gondwana (Fig. 28). Remnants of this setting are preserved, for example, in the Antalya Complex. The first evidence of rifting is the development of "geanticlines" (e.g., Hazro in southeastern Turkey; Weissbrod, 1987). Rifting began by the Late Permian, resulting in widespread marine transgression (e.g., Kantara Limestone in the Kyrenia Range). Further rifting took place in the Early Triassic, with the first evidence of widespread volcanism, recorded as tuffaceous sediments (e.g., Antalya Complex).

Final breakup took place in the Middle Triassic to Late Triassic time, marked by the incoming of deeper water radiolarian sediments (e.g., in the Antalya Complex window in the Alanya metamorphic massif). Ocean-floor spreading was in progress during the Late Tri- assic (Carnian-Norian) when transitional to MORB-type volcanics were erupted (e.g., in the Mamonia Complex in southwestern Cyprus and the Antalya Complex in southwest Turkey). Extensive Triassic volcanism also took place on the conjugate margin, e.g. in northern Syria. Associated terrigenous sediments show that the crust of the Antalya Complex formed near the rifted continental margin, and cannot represent open ocean Neotethyan lithosphere. The MORB-type volcanics in the Mamonia Complex are associated with pelagic limestones and radiolarian sediments formed in axial areas of a small Late Triassic southerly Neotethyan basin. In the south, the Levantine Basin also rifted in the Triassic, with genesis of oceanic crust by Early Jurassic time.

The Levant margin represents either an orthogonally rifted, or a transform passive margin. Regional plate reconstructions place the pole of rotation related to Late Triassic-Early Jurassic spreading far to the northwest (North Atlantic), with the implication that the Levant is a transform rifted margin (Smith, 1971; Dewey et al., 1973). However, studies of the subsidence and sedimentation history suggest more orthogonal rifting (Garfunkel and Derin, 1984; Z. Garfunkel, pers. comm., 1996). Crust north of the present latitude of $32^{\circ} 30^{\prime}$ (Fig. 6 ) is of mid-ocean-ridge type, whereas that to the south is probably thinned continental crust, or "transitional" crust (e.g., including magmatic rocks intruded into stretched continental crust). The Eratosthenes Seamount is interpreted as a continental fragment, associated with mafic igneous rocks, that was rifted from the Levant continental margin in the Triassic.

On a more regional scale, large continental fragments were rifted from the north margin of Gondwana to form the northern margin of the (southerly) Neotethyan ocean basin. Carbonate platforms were established on these units from the Late Permian-Triassic onward. Doubt persists as to which of these formed single microcontinental units, as opposed to smaller fragments. However, in the west the Bey Dağları carbonate platform and the Menderes Massif are seen as a single microcontinental unit, separated from one or several fragments further east by a Neotethyan oceanic basin (Antalya Complex). These latter units now form the Tauride Mountains of southern Turkey (e.g., Akseki and Bolkar Dağ units). Rifting to form more a northerly Neotethyan basin also took place in the Triassic, giving rise to the "Inner Tauride ocean" (Şengör and Yilmaz, 1981; Robertson and Dixon, 1984; Robertson et al., 1996a).

\section{Jurassic-Early Cretaceous}

Both the northern and southerly margins of the southerly Neotethyan oceanic basin experienced passive margin subsidence during Jurassic-Early Cretaceous time (Table 3). This is recorded, for example, by carbonate platform development in the Levant, and within the Tauride carbonate platforms in the north. Undeformed deep-water passive margins are preserved along the Levant margin, based on borehole and seismic evidence, and presumably also underlie the Nile cone and the North African continental margin offshore. Deepwater passive margin successions accumulated around the margins of rifted continental fragments along the northern margin of the southerly Neotethys, and were later deformed and incorporated into allochthonous units (e.g., Mamonia Complex, Antalya Complex). No Jurassic oceanic crust is preserved. It probably formed but was later subducted. Continuous spreading from the Triassic to Late Cretaceous is unlikely, as the southerly Neotethyan oceanic basin remained too small to be detected using paleomagnetic methods (Morris, 1996).

One alternative view is that spreading of the southerly Neotethyan ocean basin did not begin until the Cretaceous (Dercourt et al., 1986). Early Cretaceous volcanism in the Levant could then relate to Cretaceous spreading. More recently this volcanism was suggested to relate to hotspot activity within the Levant passive margin (Z. Garfunkel, pers. comm., 1996). Late Jurassic? alkaline to per-alkaline 
Table 3. Summary of events along the North African and Levant margins.

NORTH AFRICA/LEVANT

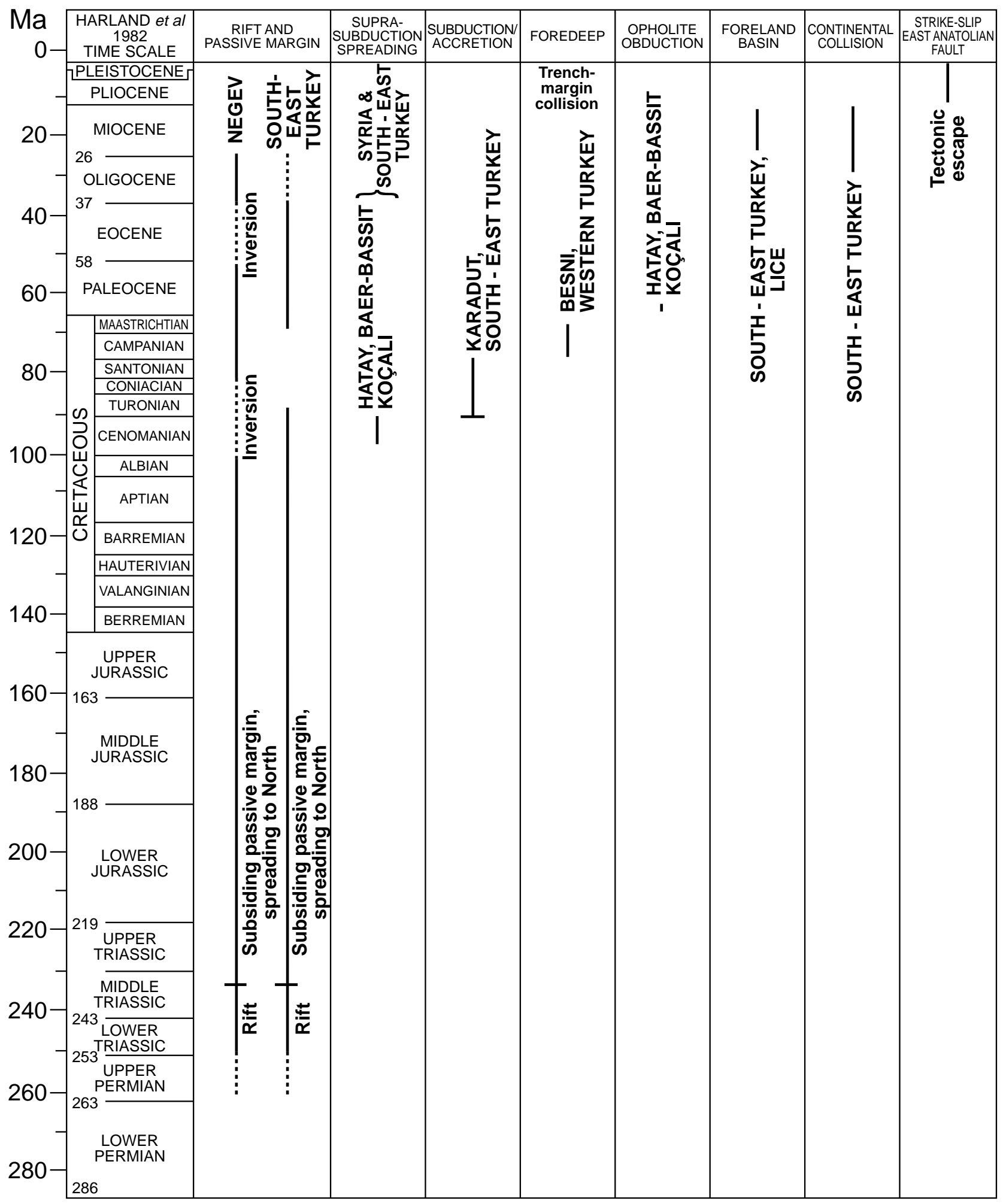

Note: See text for explanation. 
Table 4. Summary of events along the northern margin of the easternmost Mediterranean.

ANATOLIA/CYPRUS

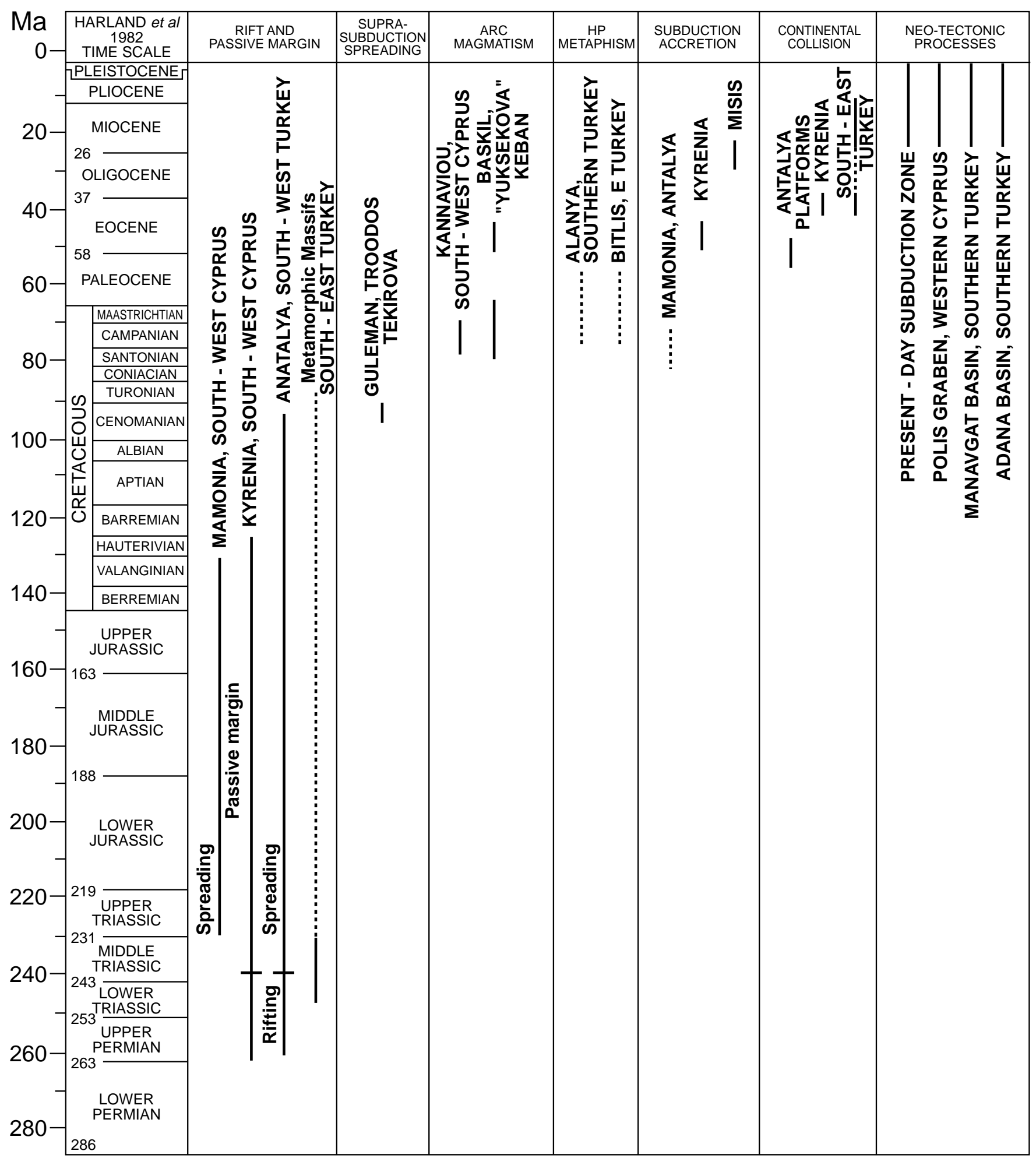

Note: See text for explanation. 


\section{LATE TRIASSIC - EARLY JURASSIC}

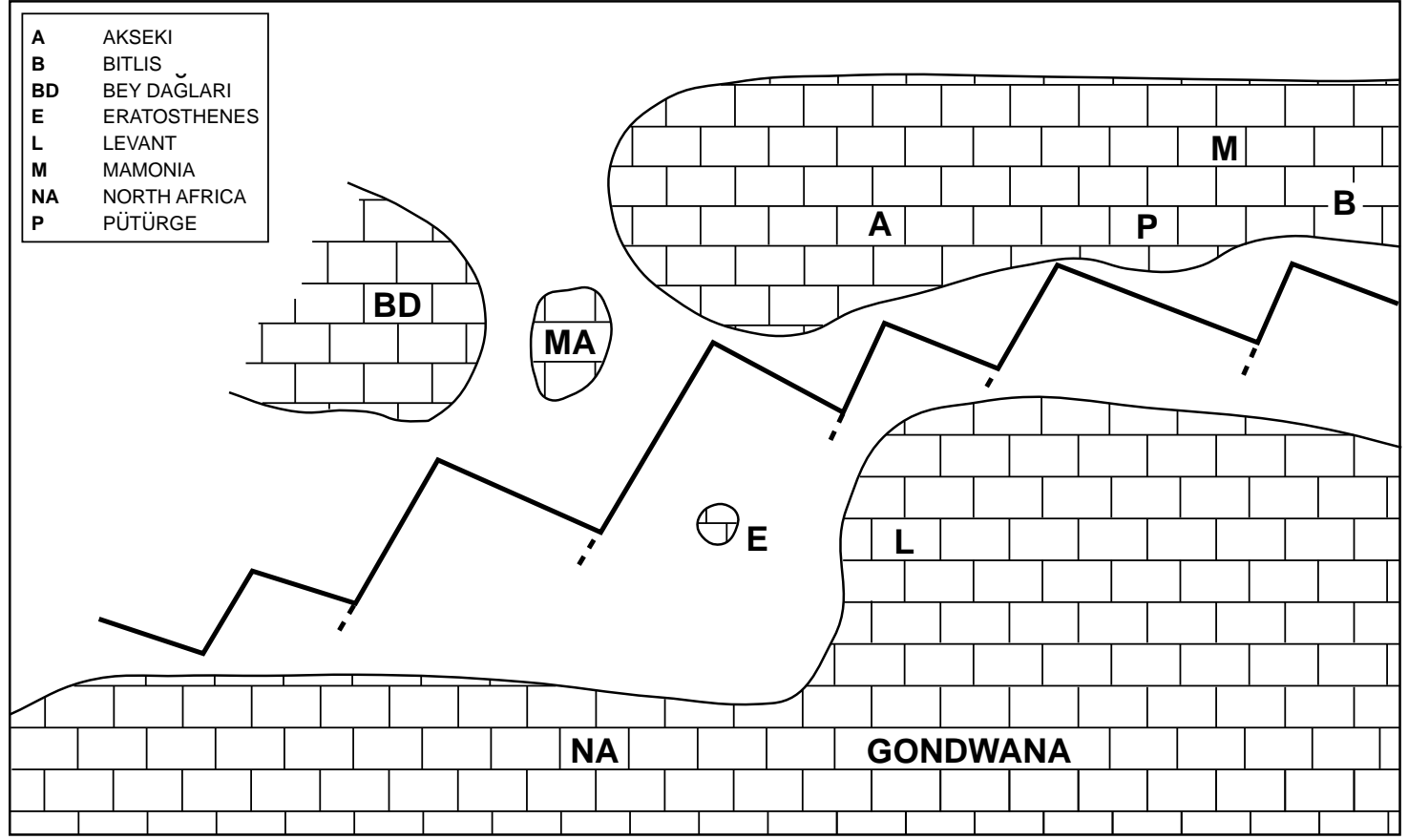

Figure 28. Plate tectonic reconstruction for the Late Triassic-Early Jurassic. The Levantine oceanic basin mainly formed in the Late Triassic-Early Jurassic. The main uncertainty is over the identity of continental fragments in the east. The initial fit develops those proposed by Robertson and Woodcock (1980) and by Garfunkel and Derin (1984). The paleolatitudes of North Africa in this and subsequent reconstructions are based on Dercourt et al. (1992). The paleolatitude of the northern margin is poorly constrained.

volcanics within allochthonous units in Baer-Bassit (northern Syria) might constitute evidence of oceanic seamounts. Some volcanism also affected other parts of the southern Neotethyan oceanic basin, as shown by the presence of disseminated hydrothermal sediments, in the Mamonia and Antalya complexes. Also, MORB-type volcanism of Early Cretaceous age is recognized in several parts of the Antalya Complex. Renewed ocean-floor spreading probably took place within the southerly Neotethyan ocean basin in Late Jurassic-Early Cretaceous time, but an oceanic basin already existed since the Triassic.

\section{Late Cretaceous: Cenomanian-Turonian}

From the late Early Cretaceous, the African and Eurasian plate began to converge as the South Atlantic opened (Fig. 29; Livermore and Smith, 1984; Savostin et al., 1986). This convergence initiated a northward-dipping subduction zone within the southerly Neotethyan oceanic basin. The cold, dense Triassic oceanic slab "rolled back," allowing asthenosphere to well up and create supra-subduction zone ophiolites, $\sim 150 \mathrm{~km}$ wide, from west to east. These include the Tekirova, Troodos, Hatay, and Baer-Bassit ophiolites. Far-field stresses related to onset of subduction may have caused compression of the Levant passive margin, thus triggering the initial inversion of the Syrian arc (as documented by offshore structure). From the Cenomanian onward, the carbonate platforms to the north subsided and were overlain by pelagic carbonate. A possible explanation is that the platforms were subjected to regional crustal extension as the pre-existing oceanic plate began to "roll back" to the south. The carbonate platform in the Kyrenia Range (northern Cyprus) may also have collapsed during this time. The supra-subduction zone oceanic slab was cut by at least one dextral transform fault, the South Troodos Transform Fault Zone, possible remnants of which also exist in southwest and west Cyprus. Within the intra-oceanic subduction zone, deep-sea sediments and MORB-type volcanics were thrust beneath still-hot Late Cretaceous ophiolitic rocks to form dynamothermal metamorphic soles (e.g., beneath Hatay and Baer-Bassit ophiolites). Remnants of a possible metamorphic sole are also present in southwest Cyprus (Ayia Varvara metamorphics).

\section{Late Cretaceous: Turonian-Upper Campanian}

As northward intra-oceanic subduction continued, the trench neared the Arabian passive margin in the east, resulting in initial depositional hiatuses. Deep-water sediments, oceanic volcanics, and carbonate build-ups were then accreted to the hanging wall of the trench to form subduction-accretion complexes, followed by underplating of deep-water passive margin sediments. The trench then collided with the Arabian passive margin, collapsing it to form a foredeep, and the entire assemblage was thrust southward to its final position as the Hatay, Baer-Bassit, and Kocali ophiolites and redeposited units. The ophiolites were briefly subaerially exposed, overlain by fluvial sediments, then transgressed by marine carbonates.

\section{Late Campanian-Maastrichtian}

The trench collided with the passive margin of Arabia in late Campanian time, $\sim 70 \mathrm{Ma}$ (Fig. 30). However, the westward extension of the intra-oceanic subduction zone and its overriding suprasubduction zone ophiolite (i.e., Troodos) remained within a remnant of the Neotethyan oceanic basin to the west. As Africa-Eurasia convergence continued, this relict trench gradually pivoted counterclockwise, explaining the paleo-rotation of a "Troodos microplate." Rotation was facilitated by continental subduction of Neotethyan crust within the Levant basin area. Such subduction may also have given rise to the Campanian Kannaviou arc-type volcaniclastic sedi- 


\section{CENOMANIAN - TURONIAN}

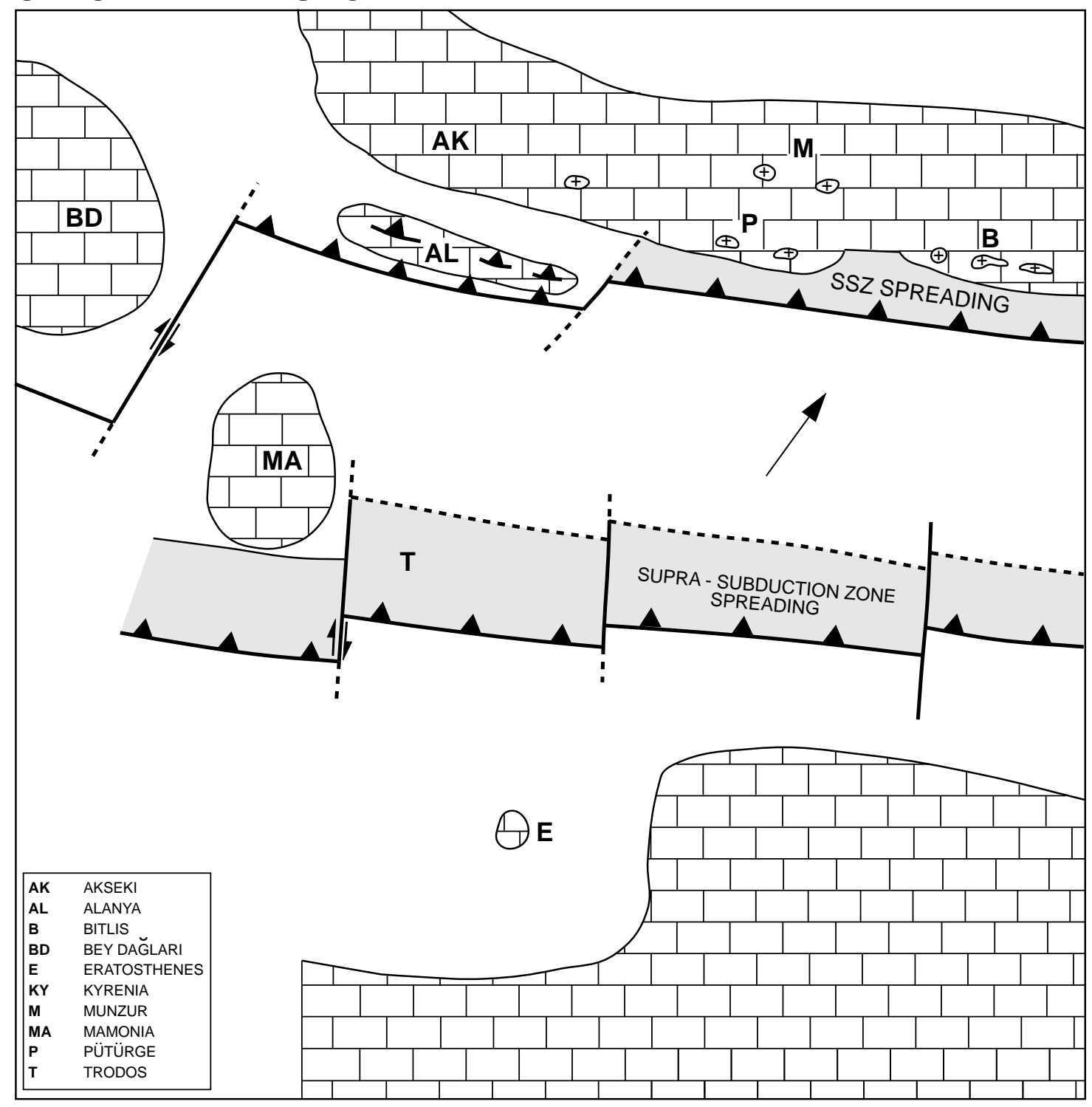

Figure 29. Plate tectonic reconstruction for the Cenomanian-Turonian. The easternmost Mediterranean oceanic basin is closing through the activity of two northward-dipping subduction zones, one intra-oceanic in the south and the other, continental margin (i.e., Andean type) in the north. Above-subduction zone spreading occurs above both of these subduction zones. The Troodos Complex forms above the southerly subduction zone. Arc volcanism develops extensively in southeast Turkey related to the northerly subduction zone.

ment in southern and southwestern Cyprus. Rotation continued at approximately the same rate $(20 \mathrm{Ma})$ from the late Campanian to the early Eocene (Morris, 1996).

Regional subduction was impeded by the collision of the intraoceanic subduction zone with the Arabian margin. Continued convergence of the African and Eurasia plates then generated an additional subduction zone along the northern margin of the Neotethyan ocean basin. This is similar, for example, to the Himalayan region, where an intra-oceanic subduction zone was created from the Mid-Cretaceous onward (i.e., Dras-Kohistan arc), whereas another subduction zone, the Gandise-Trans-Himalayan arc system, developed from the Late Cretaceous onward along the southern margin of Eurasia (Searle et al., 1987). In the easternmost Mediterranean area, evidence for this northerly Andean-type arc is most widely developed in southeastern Turkey, as shown by extensive arc-type intrusive and extrusive activity (Başkil arc unit; 85-76 Ma). The intrusions stitch both continental fragments (Keban, Bitlis, and Pütürge units) and ophiolitic crust (e.g., İspendere ophiolite). This suggests that a strip of oceanic crust was isolated behind the subduction zone and preserved intact, whereas most of the Neotethyan oceanic crust was subducted.

During the Late Cretaceous the deep-water passive margin units adjacent to the rifted microcontinents units within the Taurus Mountains (e.g., Antalya Complex) and southwest Cyprus (Mamonia Complex) were first deformed. In the case of the Antalya Complex, the cause was the collapse of small oceanic basins or broad rifts that separated a number of the carbonate platforms during the Mesozoic (e.g., Isparta Angle; Güzelsü Corridor; high-pressure unit of Alanya Massif). A possible explanation is that this compression relates to southward emplacement of ophiolites and related units from the "Inner Tauride ocean" onto the northern margin of the Tauride carbonate platforms (the Beyșehir-Hoyran Nappes, which are rooted to the north). Deformation of the northerly Neotethyan margin included 


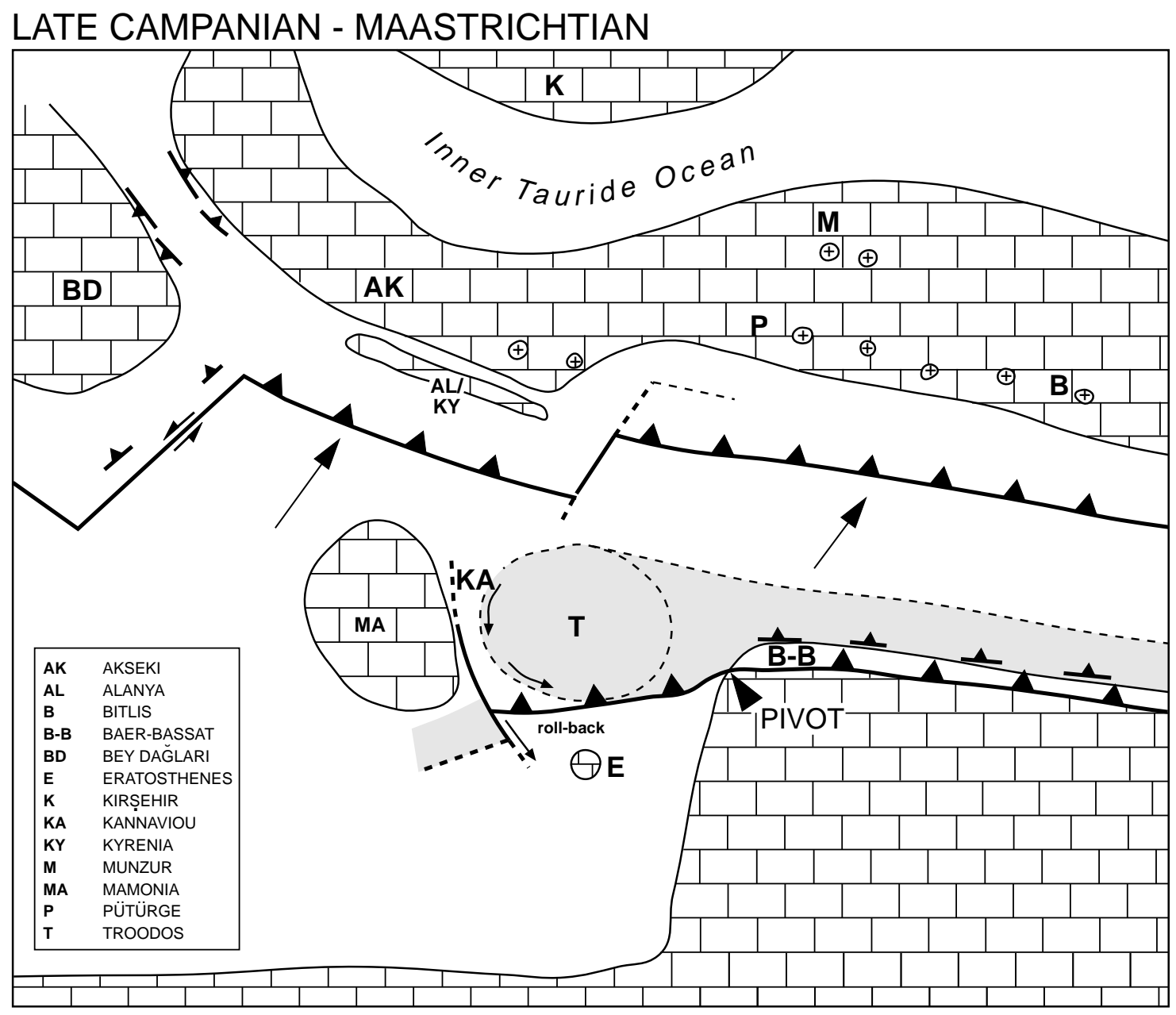

Figure 30. Reconstruction for the late Campanian-Maastrichtian. The southerly intra-oceanic subduction zone collides with the Arabian margin emplacing ophiolites, whereas the Troodos supra-subduction zone lithosphere remains in the ocean and progressively rotates counterclockwise as a microplate from Campanian to lower Eocene time. Northward subduction and arc volcanism continues along the more northerly active margin.

"docking" of the Mamonia Complex and Moni mélange in southwestern and southern Cyprus, respectively, with the Troodos ophiolite in the Maastrichtian by thrusting and/or strike-slip. This deformation may relate to the paleorotation of a "Troodos microplate."

The Kyrenia-Misis-Andirın lineament documents the history of the northern margin of the southern Neotethyan oceanic basin. This feature differs from the eastward continuation of this margin into southeastern Turkey. In the latter region an Andean-type continental margin arc developed in Campanian-Maastrichtian time at 85-76 $\mathrm{Ma}$, whereas in the Kyrenia Range Maastrichtian bimodal volcanics lack any identifiable subduction component. Their eruption into a deep-water basin, associated with syntectonic deposition (e.g., carbonate breccia deposition), is consistent with a setting as an extensional, or transtensional basin. This basin might have developed in response to counterclockwise rotation of the Troodos microplate. At present, there is no direct geological evidence to support the suggestion by Kempler and Garfunkel (1994) that the Kyrenia Range is an allochthonous terrain that was transported $\sim 150 \mathrm{~km}$ eastward to its present position before the late Eocene. Much depends on when final collision took place in southeastern Turkey. If in the late Eocene, then westward "tectonic escape" may date from this time. However, if collision was not complete until the Miocene, as is likely, then any lateral shift is likely to date only from the late Miocene-Pleistocene (along the East Anatolian transform). Before collision and tectonic escape, there is no obvious mechanism for large-scale westward strike-slip of the Kyrenia Range.

\section{Paleocene-Lower Eocene}

Africa-Eurasia relative plate convergence may paused during early Tertiary time (70-48 Ma.). There is no known record of subduction-related volcanism in southeastern Turkey from the Maastrichtian to the early Eocene. However, Mesozoic oceanic crust still remained, both to the north, adjacent to the southern margin of Eurasia (Şengör and Yilmaz, 1981; Robertson and Dixon, 1984), and within the southern Neotethyan oceanic basin in the easternmost Mediterranean area. During the Eocene, convergence resumed and remaining northerly Neotethyan oceanic crust (i.e., north of the Tauride carbonate platform) was subducted. The deformation front then migrated progressively southward.

Upper Paleocene-lower Eocene saw final closure of the Isparta Angle seaway, with expulsion of Mesozoic deep-sea and ophiolitic units, both eastward over the eastern limb of the Isparta Angle and westward over the eastern limb of the Isparta Angle. At this stage, the Isparta Angle was still a much more open feature than today.

In the Kyrenia Range, within-plate-type volcanism ended in the lower Eocene (Ayios Nikolaos Formation). This was also the time when paleorotation of the Troodos microplate ended. There is no ev- 
MIDDLE - LATE EOCENE

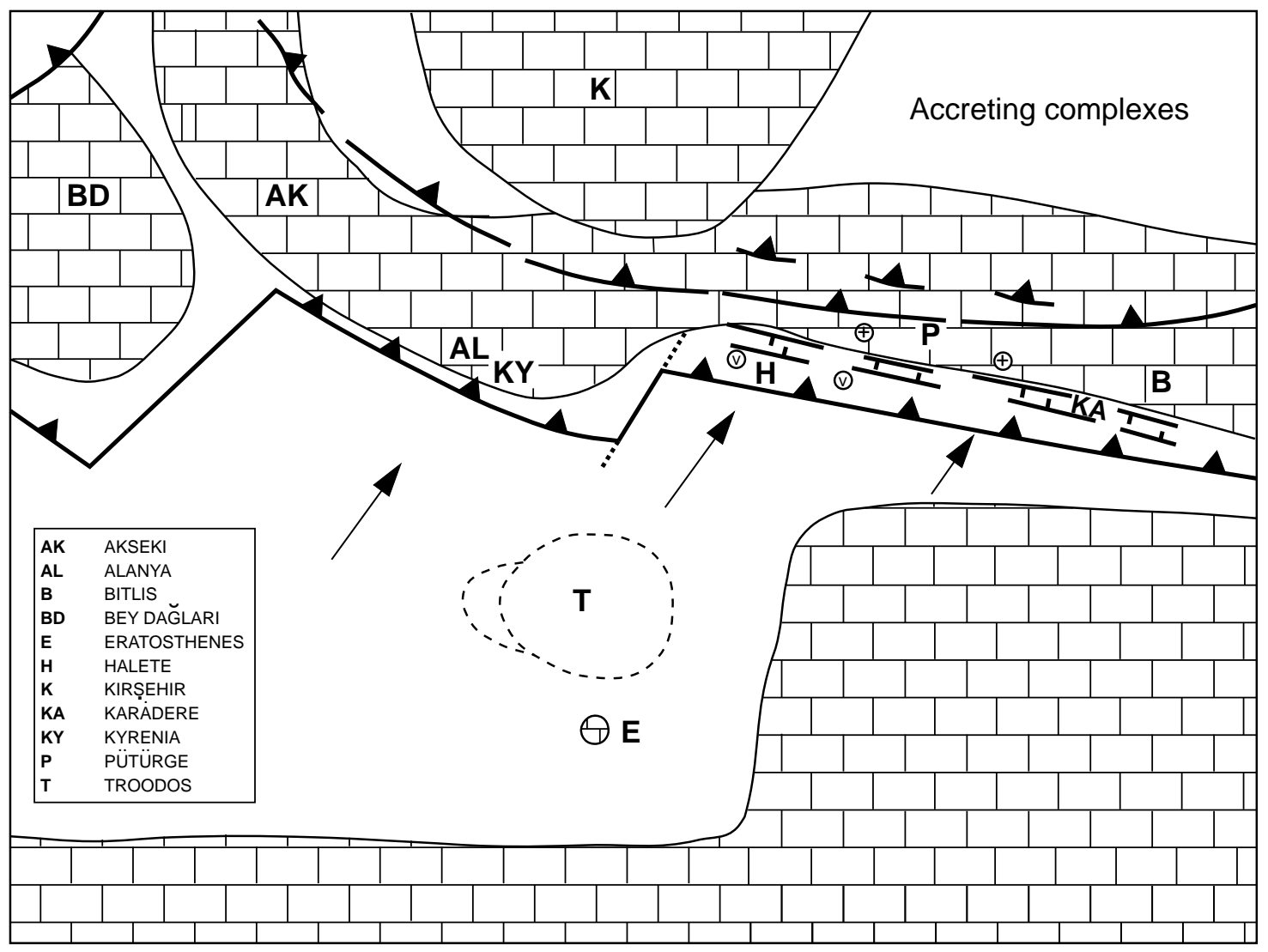

Figure 31. Reconstruction for the middle-late Eocene. Subduction resumes along a partly amalgamated northern margin, together with limited arc volcanism. Middle Eocene volcanics in southeast Turkey either formed in a continental margin arc setting (i.e., Halete volcanics), or in a transtensional pull-apart basin setting (i.e., Karadere volcanics), or conceivably both settings. The Isparta Angle Neotethyan oceanic basin is by then closed in the north, but remains open in the south.

idence of plate convergence during Paleocene-early Eocene time in this area.

\section{Middle-Late Eocene}

Northward subduction in southeastern Turkey resumed in latest Paleocene, giving rise to an accretionary prism (Killan Unit of the Maden Complex), together with limited middle Eocene calc-alkaline volcanism further north (Başkil unit; (Fig. 31). A deep-water volcanic-floored basin opened in the Middle Eocene (Karadere Unit), probably as a short-lived marginal basin, influenced by strike-slip. The setting can be compared with the Tyrrhenian Sea (Western Mediterranean) that formed coevally with diachronous collision of forearc crust with the Italian continent to the east. During the late Miocene a small marginal basin rifted above a subducting slab of old Neotethyan oceanic lithosphere. Initial rift sediments along a small passive margin in the west were initially terrigenous. Arc volcanoes were erupted only locally in the south (Aeolian arc) where sufficient Neotethyan oceanic crust remained to fuel subduction. Similarly, the middle Eocene Karadere Unit formed immediately before collision, with fractionated arc-type? volcanism in the west where the remaining Neotethyan basin was wider.

Collision ensued from the late Eocene onward, tightening the suture zone, and the collision zone migrated westward toward the easternmost Mediterranean, where Neotethyan oceanic crust still re- mained. In the Kyrenia Range, northward subduction gave rise to an accretionary prism during middle-late Eocene time (Kalograi-Ardana "olistostromes"), including large blocks of Upper Permian shallowwater limestone (Kantara Limestone).

Late Eocene was the time of final closure of the "Inner Tauride ocean" to the north of the Tauride carbonate platforms (Şengör and Yilmaz, 1981; Robertson and Dixon, 1984). As a result, the BeyşehirHoyran nappes (and counterparts to the east, the Hadim Nappes) were thrust southward over the Tauride carbonate platforms to their most southerly locations. This southward thrusting deformed the northern margin of the remaining southern Neotethyan oceanic basin, and triggered southward migration of the deformation front toward the remaining southern Neotethyan oceanic basin. In the west, the Beyșehir-Hoyran nappes were thrust southwestward, re-thrusting the northeastern segment of the Antalya Complex. In response to regional north-south compression, the Antalya Complex (Güzelsü Unit) and the Alanya Massif were finally thrust northward over the neighboring carbonate platform (Akseki Platform). The Kyrenia Range was thrust southward over a middle Eocene inferred trench-accretionary unit (Kalagrai-Ardana unit) as a stack of dismembered thrust sheets.

In southeastern Turkey, the middle Eocene deep-water volcanicfloored basin (Karadere Unit) collapsed, and was overthrust by metamorphic massifs representing the continental margin to the north. In the northern Syrian platform, carbonate sedimentation experienced depositional hiatuses in the middle Eocene, culminating in a major 


\section{EARLY MIOCENE}

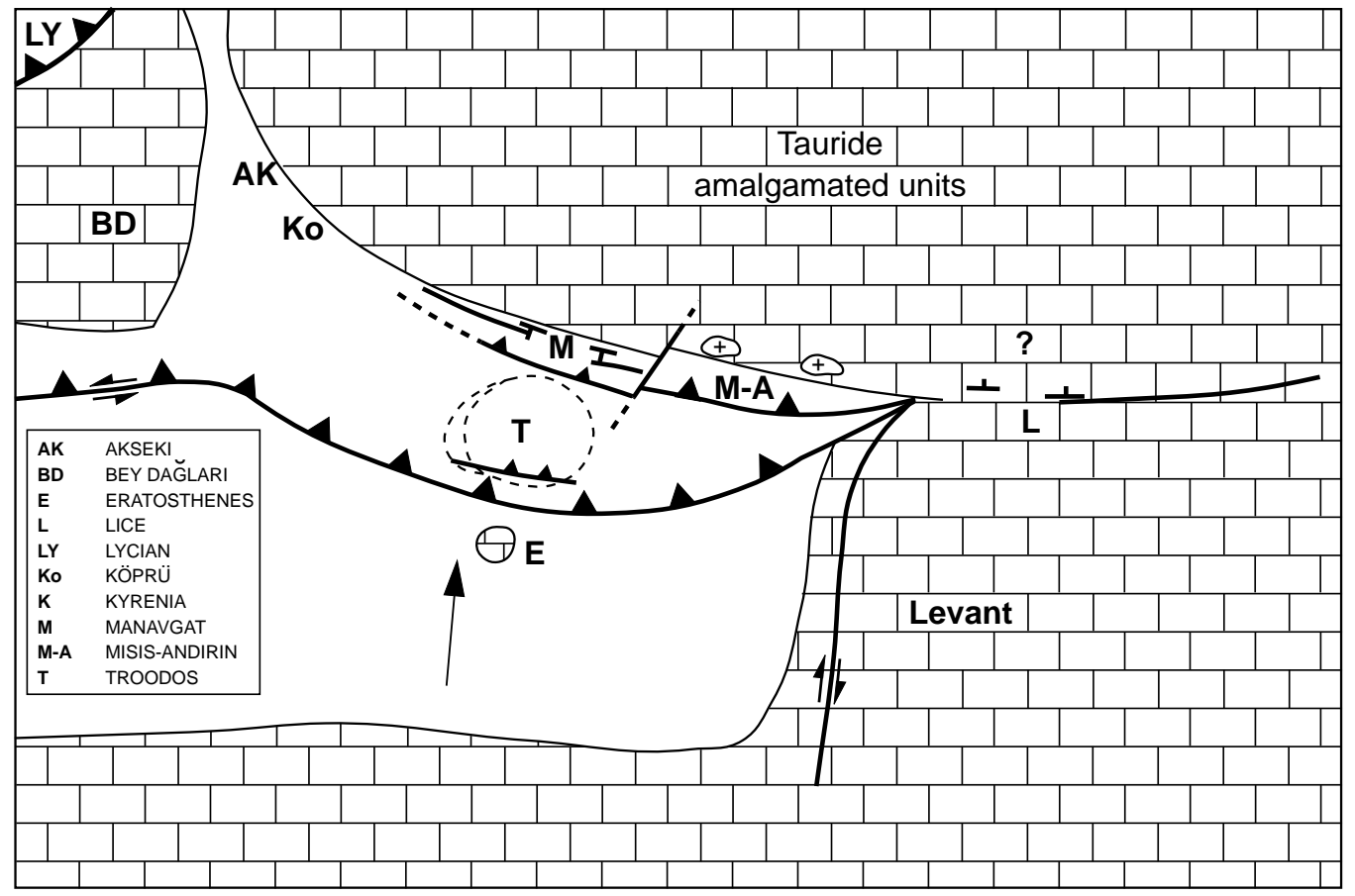

Figure 32. Reconstruction for the early Miocene. Final, localized subduction along the northern margin, followed by southward jump of subduction zone to near its present relative location. Localized compression is related to establishment of a new subduction zone south of Cyprus. Thrusting occurs over the Arabian margin in the east with development of a flexural foredeep. The Lycian nappes advance from the northwest associated with inferred strike-slip and extensional basin formation in the Isparta angle area. Extension and subsidence take place along the south margin of this northern collage.

regional unconformity, followed by renewed deposition in the early Miocene (Krashenninikov, 1994). The upper Eocene was marked by a phase of inversion of the Syrian Arc in the Levant, suggesting that compression was translated from the Eurasian plate to the Arabian plate during the time in response to initial collision with northerly units. By contrast, the Troodos ophiolite still lay to the south of the deformation front, and deep-water pelagic carbonates (Lefkara Formation) continued to accumulate during this time interval.

\section{Oligocene}

During the early Oligocene, accumulation was influenced by block faulting in southern Turkey (Adana Basin), related to compression from north. Pelagic carbonates continued to accumulate on the Troodos ophiolite further south (Upper Lefkara Formation) in a relatively stable deep-sea setting. Then, in the late Oligocene, marked changes took place throughout the region. The Kyrenia Range that hitherto had been receiving coarse alluvial sediment from the paleoSeyan river in southern Turkey subsided and passed rapidly upward into turbiditic sediments (Kithrea Flysch). The onshore Adana Basin also subsided, ushering in marine sedimentation influenced by block faulting, and marking activation of a northward-dipping subduction zone to the south. Sedimentary mélange of upper Oligocene-lower Miocene age (Isali unit) formed further south, in the Misis-Andırın Complex, within an extensional fore-arc setting. The clasts were mainly derived from earlier-emplaced units to the north (e.g., Mesozoic limestone, ophiolites etc.). Limited acidic, calc-alkaline, arcrelated volcanism (represented by tuffs) took place at this time, but a rifted back-arc basin did not develop. Instead, the ophiolitic blocks in the mélange were derived from previously emplaced (?Late Cretaceous) units. The "olistostrome" is interpreted as a trench-accretion- ary complex related to northward subduction of Neotethyan oceanic crust to the south, coupled with fore-arc extension.

\section{Miocene}

Early Miocene time saw activity along the present subduction zone south of Cyprus, as part of the wider regional Africa-Eurasian plate boundary including the Aegean active margin (Aegean arc; Figs. 32, 33). A possible explanation for southward migration of the subduction zone is that remaining old, early Mesozoic, Neotethyan crust was consumed, juxtaposing younger, more buoyant suprasubduction zone-type Upper Cretaceous oceanic crust with the active margin to the north. This was difficult to consume, and the subduction zone then relocated itself within early Mesozoic oceanic crust further south. This subduction could effectively have reactivated a Late Cretaceous subduction zone above which the Troodos was previously created by supra-subduction zone spreading. During the Late Cretaceous, northward subduction had already carried the rifted Eratosthenes block (a continental fragment) toward the Troodos, then located on an opposing plate.

From the early Miocene onward, Cyprus was located on the overriding plate of a northward-dipping subduction zone. The leading edge was dissected into sub-basins. Some of these reached sea level and were colonized by reefs, whereas others still underwent pelagic carbonate accumulation. In northern Cyprus, an extensional graben formed in the northern Mesaoria Plain area, bounded by the Ovgos Fault to the south and the Kithrea Fault to the north. In the Adana and Manavgat Basins, subsidence in the middle Miocene (Langhian) is attributed to extensional faulting. Extensional faulting also gave rise to large pre-Messinian marine basins, including the onshore Polis graben (western Cyprus), the Antalya Basin, the Cilicia-Adana Ba- 


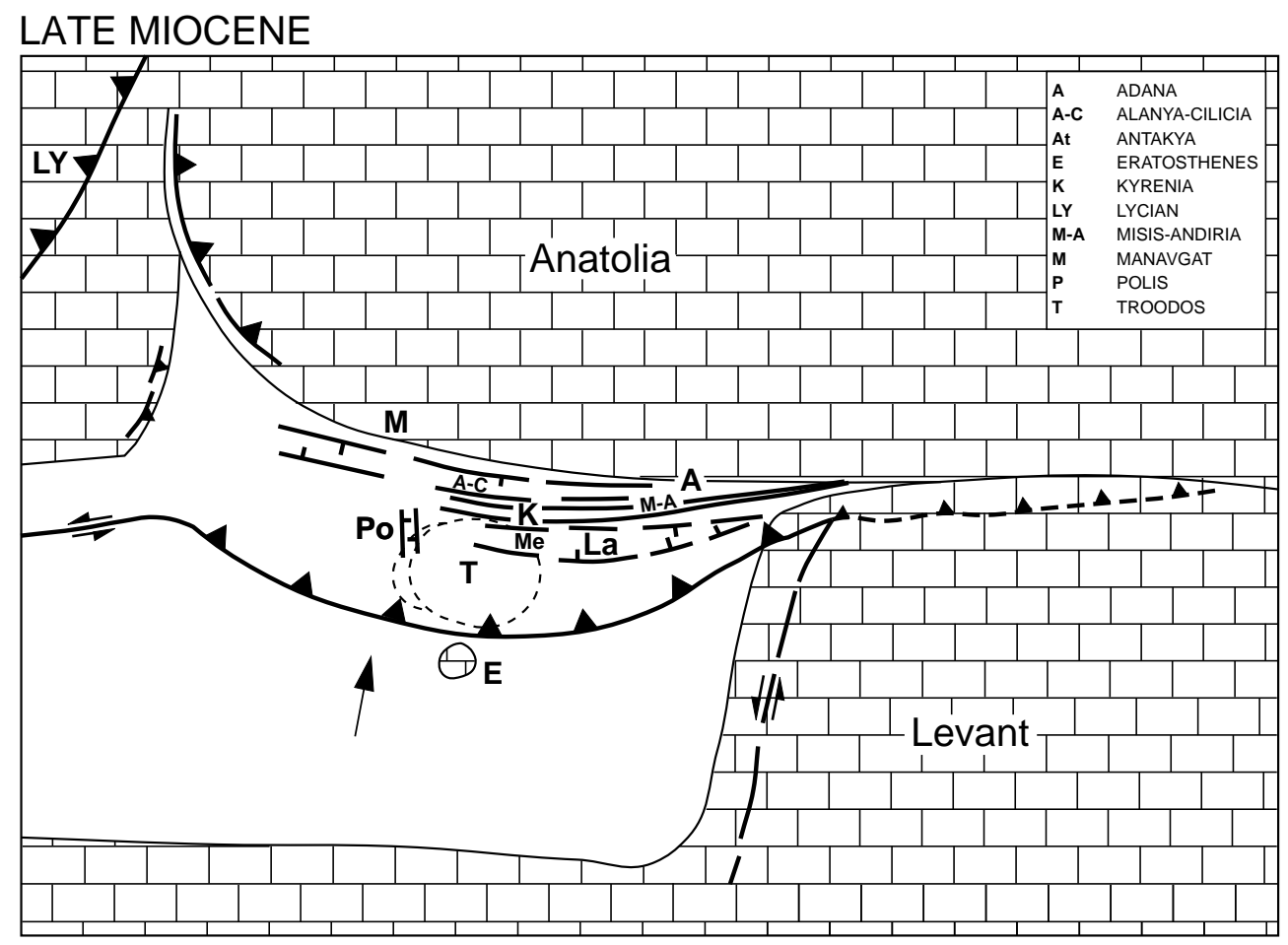

Figure 33. Reconstruction for the late Miocene. Southward-thrust emplacement is completed in southeast Turkey. Strike-slip along Dead Sea transform is active; subduction continues in Levantine Sea, with "roll-back" giving rise to extensional basins in the overriding plate. During the late Miocene the Lycian nappes are finally emplaced, associated with compression of the Isparta angle area, and localized thrusting in the southwest and east segments of the Antalya Complex.

sin, and the Latakia Basin. The overall cause of this extension was possibly southward retreat of an early Mesozoic-aged oceanic slab ("roll-back"). The Messinian salinity crisis was superimposed on this highly variable tectonic setting. Highs such as the Eratosthenes Seamount, or the Akamas Peninsula of western Cyprus were emergent and karstified. Gypsum was precipitated within previously shallow basins, as in southern and western Cyprus, whereas halite was precipitated in deep basins, as locally in the Mesaoria basin and extensively in the deep Levantine Basin and elsewhere.

During the Miocene a division clearly existed between a precollisional setting in the easternmost Mediterranean (west of the longitude of the Levant margin) and a collisional setting in southeastern Turkey. Regionally, plate convergence was continuing (Livermore and Smith, 1984; Savostin et al., 1986). In the east, the early Miocene Lice-Cüngüs Basin developed as a foreland basin related to overthrusting of allochthonous eastern Tauride units. The last vestiges of the Neotethys disappeared as collision proceeded westward, diachronously, although Mesozoic oceanic crust still remained in the easternmost Mediterranean. In the Adana area, the Tortonian was marked by uplift, unconformities, facies changes, and re-orientation of paleocurrents (Yetiş et al., 1995). East-west compression also affected the Aksu basin further west. These events record were consequent upon collision in southeast Turkey, and the final stages of emplacement of the Lycian Nappes (also collision related).

\section{Pliocene}

Northward Africa-Eurasia convergence finally brought the Eratosthenes Seamount into collision with the Cyprus trench (Fig. 34). As it approached the trench, this block was flexurally loaded by the overriding plate, resulting in faulting associated with mass wasting of scarps and subsidence to bathyal depths during early Pliocene time. The exact timing of initial subsidence of Eratosthenes remains un- clear, and may have preceded the early Pliocene when bathyal sedimentation was already in progress on the collapsed plateau area of the seamount (i.e., evidence from Site 966). In southern and western Cyprus, the genesis of distinctive gypsum mega-breccias within the Messinian evaporitic basin might have been triggered by initial collision. Rapid collapse of the Eratosthenes Seamount took place after the late Pliocene. During the late Pliocene, rapid uplift of both southern Cyprus and the Kyrenia Range began. The compressive effect reached beyond the boundary between the rigid Troodos ophiolitic slab and the contrasting crust of the Kyrenia Range to the north. The Kyrenia Range was uplifted to reach its maximum altitude north of the Eratosthenes Seamount collision zone. However, the AdanaCilicia Basin to the north remained largely unaffected. Also, in southwest Cyprus the onshore Pegia graben developed in late Plioceneearly Pleistocene, possibly influenced by westward tectonic escape from the Cyprus-Eratosthenes collision zone. Associated with this subduction and underthrusting of the Eratosthenes Seamount, ultramafic rocks within the overriding slab were serpentinized and rose upward diapirically, updoming the Troodos ophiolite and exposing serpentinite on Mt. Olympos.

By contrast, in coastal southern Turkey, in the Adana Basin, Pliocene sedimentation was entirely nonmarine, whereas in the Aksu Basin it was marine, but shallowed upward. Regional uplift took place in late Pliocene-early Pleistocene time, associated with crustal extension faulting (Aksu Basin) and transtension (Adana Basin).

In the northern Levant strike-slip along the main strand of the Dead Sea transform began in the early Pliocene ( $\sim 5$ m.yr.; Butler et al., 1997). The transform propagated northward to intersect with the collision zone, initiating the Marass triple junction. The triple junction links eastward with the East Anatolian Fault Zone in southeast Turkey (Gözoböl and Gürpinar, 1980; Westaway and Arger, 1996). In southeastern Turkey, left-lateral strike-slip along the East Anatolian Fault (Hempton, 1982) began in the early Pliocene with a total dis- 


\section{LATE PLIOCENE - QUATERNARY}

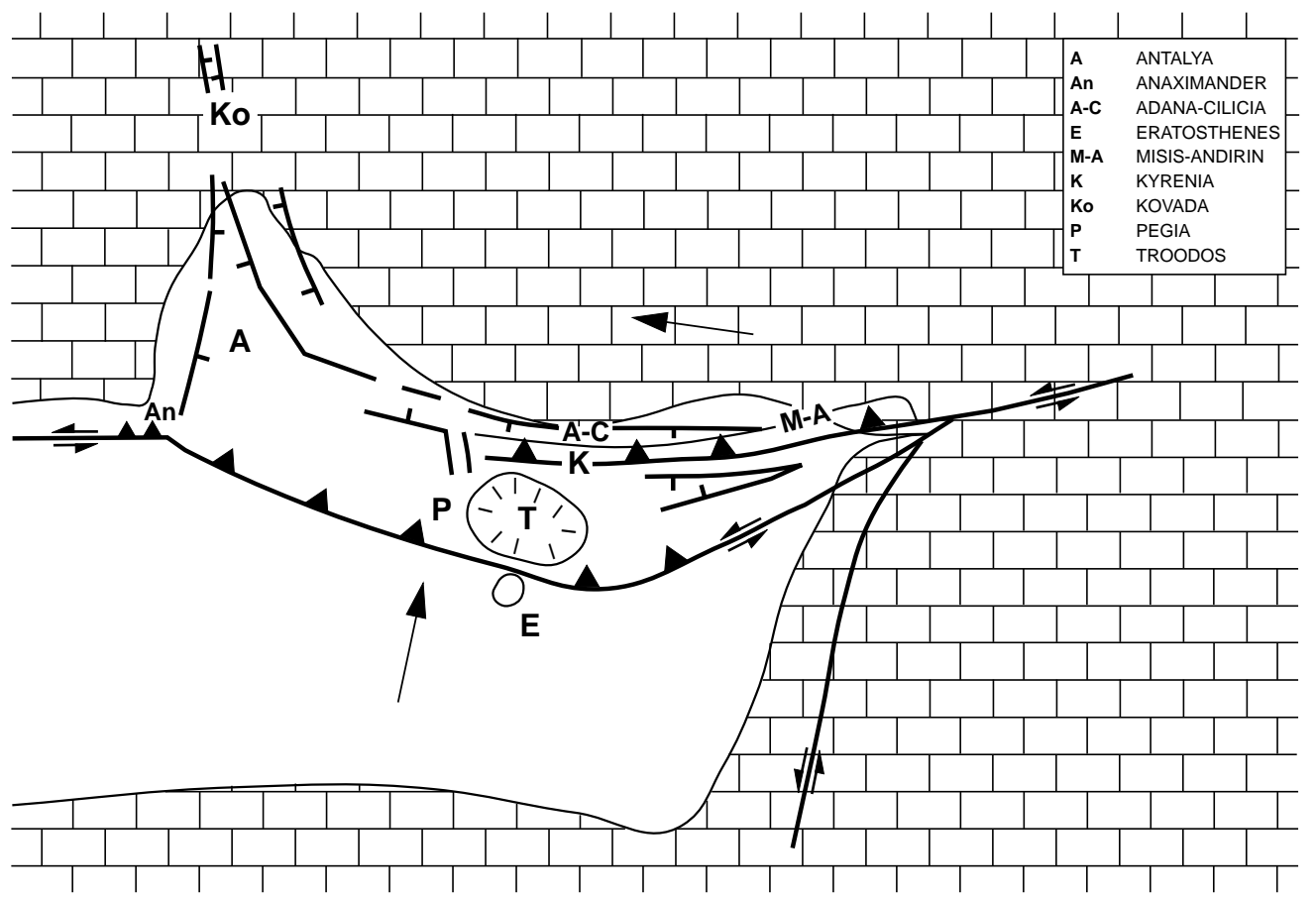

Figure 34. Reconstruction for late Pliocene-Quaternary time. Following collision of Arabia with Eurasia, Anatolia undergoes westward tectonic escape. The inferred direction of subduction in the Levantine Sea is north-northeastward. The Eratosthenes Seamount is being thrust beneath Cyprus. The Troodos is strongly updomed in response to collision and related serpentinite diapirism. Extensional basinal formation continues in other areas of the over-riding plate and locally onshore in the Aksu basin (southwest Turkey).

placement of $<25 \mathrm{~km}$. Left-lateral displacement was more pronounced along the North Anatolian transform fault (Barka and Hancock, 1984; Dewey et al., 1986). Deformation in the Misis Mountains is mainly extensional, or transtensional in the Pliocene-Pleistocene and there is, thus, little evidence that the late Pliocene-Pleistocene uplift of the Kyrenia Range was caused by transpression (Kempler and Garfunkel, 1991). Significant strike-slip along the Kyrenia stage is also unlikely, as the eastern margin of the southern Antalya Basin does not appear to be offset by lateral faults. Instead, the uplift of the Kyrenia Range probably relates to collision of the Eratosthenes Seamount to the south. The Troodos ophiolite and the Kyrenia Range were both uplifted with respect to surrounding areas. Westward escape of Anatolia during Pliocene-Pleistocene time was accompanied by a reorientation of subduction from northward to more northeastward, consistent with the instantaneous GPS data for southern Turkey (Oral et al., 1994; Töksöz et al., 1995; Barka et al., 1997).

\section{Pleistocene-Holocene}

Existing plate boundaries were active during this time. Northeastward subduction was active beneath southwest Cyprus and the southern Antalya Bay area. Crustal extension has continued onshore in the Antalya Basin. The Florence Rise represents the leading edge of the Eusarian plate. The Florence Rise in contiguous with the Anaximander Mountains, an offshore extension of units exposed in southern Turkey, including the Antalya Complex. The south margin of the Anaximander Mountains is seen as a left-lateral strike-slip zone that links with the Strabo trench to the west. Further west, the Eratosthenes Seamount is possibly now being thrust northeastward obliquely beneath Cyprus (perhaps causing rotation of the Seamount). Uplift of the Troodos ophiolite and the Kyrenia Range apparently diminished after mid-Pleistocene time. The eastward extension of the Cyprus trench is a zone of left-lateral strike-slip, passing into a zone of distributed strike-slip, transtension, and transpression within the Cyprus-Latakia link zone to the north. Left-lateral strike-slip continues along the East Anatolian Fault Zone, and also affects onshore areas of the northern Levant margin further south (Latakia area).

\section{CONCLUSIONS}

From Late Permian to Holocene, the Levant-North African margin has remained passive. However, the Arabian promontory was deformed, related to collision with an intra-oceanic subduction zone in the Late Cretaceous, emplacing ophiolites southward. The Arabian margin was again deformed in the Late Eocene to Miocene, related to progressive suturing of the Neotethys ocean.

By contrast, the northern margin of the southern Neotethyan ocean basin exhibits a dominantly extensional history, with phases of extension in the Triassic-early Late Cretaceous, Maastrichtian-lower Eocene, late Oligocene, late Miocene and, locally late PlioceneHolocene. After the Triassic, all these phases can be broadly related to the effects of southward retreat of one, or several, northward-dipping subduction zones. Slab retreat ("rollback") has played a key role. More locally, the Maastrichtian-lower Eocene history of the Kyrenia Range and Mamonia Complex in Cyprus relate to paleorotation of a Troodos microplate. Dominant extension along the northern margin was punctuated by compressional phases in the Late Cretaceous, late Eocene, and, locally, in Pliocene-Pleistocene time. The two earlier compressional events relate to initial and then final closure of separate Neotethyan basins to the north ("Inner Tauride Ocean"), whereas the last-mentioned event relates to localized collision of the Eratosthenes Seamount with the Cyprus active margin.

During the Late Cretaceous, two north-dipping subduction zones were established within the southerly Neotethyan oceanic basin. The first was an intra-oceanic subduction zone (Cenomanian-Turonian) 
that generated the Late Cretaceous ophiolite (e.g., Troodos). After this subduction zone collided with the Arabian margin to the southeast (Late Campanian), an additional subduction zone was active along the northern margin of the Neotethyan basin in southeastern Turkey (Campanian-Maastrichtian). In the Tertiary, only one subduction zone remained along the northern Neotethyan margin (then an Andean-type margin), and this was active in the early-middle Eocene (in southeastern Turkey). Continental collision began in the late Eocene, and progressively consumed remaining oceanic crust until suturing was complete in the late Miocene. Subduction and arc volcanism persisted into the early Miocene further west, along northern margin of the easternmost Mediterranean basin. Subduction "jumped" to the present plate boundary south of Cyprus in the early Miocene. Continuing subduction then caused the Eratosthenes seamount to collide with the Cyprus active margin by the earliest Pliocene, initiating rapid uplift of Cyprus from late Pliocene to midPleistocene time. Meanwhile, westward tectonic escape of Anatolia is in progress to the north.

\section{ACKNOWLEDGMENTS}

For helpful discussion I particularly thank shipboard colleagues of the Gelendzyk and the JOIDES Resolution. Special thanks go to John Dixon, Anatoly Limonov, John Woodside, Costas Xenophontos, Rachel Flecker, Clare Glover, and Pinar Yilmaz. The manuscript benefited from comments by J.-P. Rehault and G. Kelling.

\section{REFERENCES}

Akay, E., Üysal, S., Poisson, A., Cravette, J., and Müller, C., 1985. Stratigraphy of the Antalya Neogene Basin, Bull. Geol. Soc. Turkey, 28:105-119.

Akbulut, A., 1977. Etude géologique d'une partie du Taurus occidentale au sud d'Eğridir (Turkquie) [Thèse]. Univ. Paris-Sud, Orsay.

Aksu, A.E., Calon, T., Piper, D.W.J., Turgut, S., and Izdar, E., 1992a. Architecture of later orogenic Quaternary basins in northeastern Mediterranean Sea. Tectonophysics, 210:191-213.

Aksu, A.E., Ulug, A., Piper, D.W.J., Konuk, Y.T., and Turgut, S., 1992b. Quaternary sedimentary history of Adana, Cilicia and Iskenderun Basins: northeastern Mediterranean Sea. Mar. Geol., 104:55-71.

Aktaş, G., 1985. The Maden Complex, S.E. Turkey: sedimentation and volcanism along a Neotethyan active continental margin [Ph.D. thesis]. Univ. Edinburgh.

Aktaş, G, and Robertson, A.H.F., 1984. The Maden Complex, SE Turkey: evolution of a Neotethyan continental margin. In Dixon, J.E., and Robertson, A.H.F. (Eds), The Geological Evolution of the Eastern Mediterranean. Geol. Soc. Spec. Publ. London, 17:375-402.

1990a. Tectonic evolution of the Tethys suture zone in S.E.Turkey: evidence from the petrology and geochemistry of Late Cretaceous and Middle Eocene Extrusives. In Moores, E.M., Panayiotou, A., and Xenophontos, C. (Eds), Ophiolites: Oceanic Crustal Analogues. Proc. Int. Symp. “Troodos 1987," Geol. Surv. Dep., Cyprus, 311-329.

_ 1990b. Late Cretaceous-Early Tertiary fore-arc tectonics and sedimentation: Maden Complex, S.E. Turkey. In Savascin, M.Y., and Eronat, A.H. (Eds.), Int. Earth Sci. Congr. on Aegean Regions, Izmir, Turkey, 2:271-276.

Allerton, S., and Vine, F.J., 1987. Spreading structure of the Troodos ophiolite, Cyprus: some palaeomagnetic constraints. Geology, 15:593-597.

Almogi-Labin, A., Eshet, Y., Flexer, A., Honigstein, A., Moshkovitz, S., and Rosenfeld, A., 1991. Detailed biostratigraphy of the Santonian/Campanian boundary interval in northern Israel. J. Micropaleontol., 10:39-50.

Ambreseys, N.N., and Adams, R.D., 1993. Seismicity of the Cyprus region. Terra Nova, 5:8-94.

Anastasakis, G., and Kelling, G., 1991. Tectonic connection of the Hellenic and Cyprus arcs and related geotectonic elements. Mar. Geol., 97:261277.
Angelier, J., Lyberis, N., Le Pichon, X., Barrier, E., and Huchon, P., 1982. The tectonic development of the Hellenic arc and the sea of Crete: a synthesis. Tectonophysics, 86:159-196.

Anonymous, 1995. Transform tectonics of the West African margin explored. Eos, 76:299-300.

Bagnall, P.S., 1964. Wrench faulting in Cyprus. J. Geol., 72:327-343.

Bailey, W., 1996. The structural and geochemical evolution of a microplate suture zone south west Cyprus. JAGSPEI Meeting, Structure and Origin of Troodos Ophiolite, Cyprus. (Abstract)

Barka, A.A., and Hancock, P.L., 1984. Neotectonic deformation patterns in the convex-northwards arc of the North Anatolian fault zone. In Dixon, J.E., and Robertson, A.H.F. (Eds), The Geological Evolution of the Eastern Mediterranean. Geol. Soc. Spec. Publ. London, 17:763-774.

Barka, A.A., Reilinger, R., Saröglü, F., Şengör, A.M.C., 1997. The Isparta Angle: its importance in the neotectonics of the Eastern Mediterranean Region. In Pişkin, O., Ergun, M., Savaşçin, M.Y., and Tarcan, G. (Eds.), International Earth Sciences Colloquium on the Aegean Region, 9-14 October, 1995, Izmir-Golluk, Turkey, 1:3-18.

Baroz, F., 1979. Etude géologique dans le Pentadaktylos et la Mesaoria (Cypre septentrionale) [Ph.D. thesis]. Univ. of Nancy, France.

, 1980. Volcanism and continent-island arc collision in the Pentadaktylos range, Cyprus. In Panayiotou, A. (Ed.), Ophiolites Proc. Int. Symp., Nicosia, Cyprus, 73-75.

Ben-Avraham, Z., 1986. Multiple opening and closing of the Eastern Mediterranean and South China Basins. Tectonics, 8:51-362.

Ben-Avraham, Z., and Grasso, M., 1991. Crustal structure variations and transcurrent faulting at the eastern and western margins of the eastern Mediterranean. Tectonophysics, 75:269-277.

Ben-Avraham, Z., and Nur, A., 1982. The emplacement of ophiolites by collision. J. Geophys Res., 87:3861-3867.

, 1986. Collisional processes in the Eastern Mediterranean. Geol. Rundsch., 75:209-217.

Ben-Avraham, Z., Shoham, Y., and Ginzburg, A., 1976. Magnetic anomalies in the eastern Mediterranean and the tectonic setting of the Eratosthenes Seamount. Geophys. J. R. Astron. Soc., 45:105-123.

Ben-Avraham, Z., and Tibor, G., 1994. Structure and tectonics of the Eastern Cyprus arc. Am. Geophys. Union, 117. (Abstract)

Ben-Avraham, Z., Tibor, G., Limonov, A.F., Leybov, M.B., Ivanov, M.K., Tokarev, M.Y., and Woodside, J.M., 1995. Structure and tectonics of the Eastern Cyprean arc. Mar. Pet. Geol., 12:263-271.

Bien, A., and Gvirtzman, G., 1977. A Mesozoic fossil edge of the Arabian plate along the Levant coastline and its bearing on the evolution of the Eastern Mediterranean. In Biju-Duval, B., and Montadert, L. (Eds.), Structural History of the Mediterranean Basins. Internat. Symp. Split (Yugoslavia), Oct. 1976. Edition Technip, Paris, 1977, 95-110.

Biju-Duval, B., Dercourt, J., and le Pichon, X., 1977. From the Tethys ocean to the Mediterranean Sea: a plate tectonic model of the evolution of the western Alpine system. In Biju-Duval, B., and Montadert, L. (Eds.), Structural History of the Mediterranean Basins: Paris (Editions Technip), 143-164.

Bingöl, A.F., 1990. Petrological features of intrusive rocks of Yuksekova Complex in the Elaziğ region (Eastern Taurus-Turkey). J. Firat Univ. Sci. Tech., 3:1-17.

Bogdanov, N.A., Koronovsky, N.V., Lomize, M.G., Chekhovic, V.D., and Yutsis, V.V., 1994. Tectonic Map of Mediterranean Sea. Moscow.

Bürger, D., 1990. The travertine complex of Antalya Southwest Turkey. Zeitschrift für Geomorphologie. Neue Forschung, Suppl. Bd., 77:25-46.

Butler, R.W.H., Spencer, S., and Griffiths, H.M., 1997. Transcurrent fault activity on the Dead Sea Transform in Lebanon and its implications for plate tectonics and seismic hazard. J. Geol. Soc. London, 154:757-70.

Camerlenghi, A., Cita, M.B., Della Vedova, B., Fusi, N., Mirabile, L., and Pellis, G., 1995. Geophysical evidence of mud diapirism on the Mediterranean Ridge accretionary complex. Mar. Geophys. Res., 17:115-141.

Chaumillon, E., and Mascle, J., 1995. Variation latérale des fronts de deformation de la Ride méditerranéene (Méditerranée orientale). Bull. Soc. Geol. Fr., 166:463-478.

Clift, P.D., 1991. Collision tectonics of the southern Greek Neotethys. Geol. Rundsch., 81:669-676.

Clube, T.M.M., Creer, K.M., and Robertson, A.H.F., 1985. Palaeorotation of the Troodos Microplate, Cyprus. Nature, 317:522-525. 
Clube, T.M.M., and Robertson, A.H.F., 1986. The paleorotation of the Troodos microplate, Cyprus in the Late Mesozoic-Early Cenozoic plate tectonic framework of the Eastern Mediterranean. Surv. Geophys., 8:375437.

Cohen, Z., Flexer, A., and Kaptsan, V., 1990. The tectonic mosaic of the southern Levant: implications for hydrocarbon prospects. J. Pet. Geol., 13:437-462.

Collins, A., and Robertson, A.H.F., 1997. Lycian melange, southwestern Turkey: an emplaced Late Cretaceous accretionary complex. Geology, 25:255-258.

De Graciancky, P.C., 1972. Récherchers géologiques dans les Taurus Lycien [Thèse DSc.] Univ. de Paris Sud.

de Jonge, M.R., Wortel, M.J.R., and Spakman, W., 1994. Regional scale tectonic evolution of the seismic velocity structure of the lithosphere and upper mantle: the Mediterranean region. J. Geophys. Res., 899:1209112108.

Delaloye, M., De Souza, H., and Wagner, J.-J., 1980. Isotopic ages of ophiolites from the Eastern Mediterranean. In Panayiotou, A. (Ed), Ophiolites. Proc. Internat. Symp., Nicosia, Cyprus, 292-295.

Delaloye, M., and Wagner, J.-J., 1984. Ophiolites and volcanic activity near the western edge of the Arabian plate. In Dixon, J.E., and Robertson, A.H.F. (Eds.), The Geological Evolution of the Eastern Mediterranean. Geol. Soc. Spec. Publ. London, 17:225-233.

Delaune-Mayere, M., 1984. Evolution of a Mesozoic passive continental margin: Baer-Bassit (NW Syria). In Dixon, J.F., and Robertson, A.H.F. (Eds.), The Geological Evolution of the Eastern Mediterranean. Spec. Publ. Geol. Soc. London, 17:11-10.

Delaune-Mayere, M., Marcoux, J., Parot, J.F., and Poisson, A., 1976. Modèle d'évolution mésozoique de la paléo-marge téthysienne au niveau des nappes radiolaritiques et ophiolitiques du Taurus Lycien, d'Antalya et du Baer-Bassit. In Biju-Duval, B., and Montadert, L. (Eds.), International Symposium on the Structural History of the Mediterranean Basins: Paris (Editions Technip), 79-94.

Dercourt, J., Ricou, L.E., and Vrielynck, B. (Eds.), 1992. Atlas of Tethys Palaeoenvironmental Maps: Paris (Gauthier-Villars).

Dercourt, J., Zonenshain, L.P., Ricou, L.E., Kazmin, V.G., Le Pichon, X., Knipper, A.L., Grandjacquet, C., Sbortshikov, I.M., Geyssant, J., Lepvrier, C., Pechersky, D.H., Boulin, J., Sibuet, J.C., Savostin, L.A., Sorokhtin, O., Westphal, M., Bazhenov, M.L., Lauer, J.P., and BijuDuval, B., 1986. Geological evolution of the Tethys belt from the Atlantic to the Pamirs since the Lias. Tectonophysics, 123:241-315.

Derman, A.S., Akdag, K., Gül, M.A., and Yeniay, G., 1996. Relationship between sedimentation and tectonics in the Marass Miocene Basin. Turk. Assoc. Petrol. Geol. Publ., 11th Petrol. Congr. Turk., 91-102.

Dewey, J.F., Hempton, M.R., Kidd, W.S.F., Saröğlü, F., and Şengör, A.M.C., 1986. Shortening of continental lithosphere: the Neotectonics of Eastern Anatolia: a young collision zone. Geol. Soc. Spec. Publ. London, 19:336.

Dewey, J.F., Pitman, W.C., Ryan, W.B.F., and Bonin, J., 1973. Plate tectonics and the evolution of the Alpine system. Geol. Soc. Am. Bull., 84:31373180.

Dewey, J.F., and Şengör, A.M.C., 1979. Aegean and surrounding areas: complex multi-plate and continuum tectonics in a convergent zone. Geol. Soc. Am. Bull., 90:84-92.

Dilek, Y., and Delaloye, M., 1992. Structure of the Kizıldağ ophiolite, a slow-spread Cretaceous ridge segment north of the Arabian promontory. Geology, 20:19-22.

Dilek, Y., and Moores, E.M., 1990. Regional tectonics of the Eastern Mediterranean ophiolites. In Malpas, J., Moores, E.M., Panayiotou, A., and Xenophontos, C. (Eds.), Ophiolites Oceanic Crustal Analogues. Proc. Symp. "Troodos 1987," Geol. Surv. Dep., Cyprus, 295-309.

Dilek, Y., Moores, E.M., Delaloye, M., and Karson, J.A., 1991. A magmatic extension and tectonic denudation in the Kizıldağ Ophiolite, southern Turkey: implications for the evolution of Neotethyan oceanic crust. In Peters, T., Nicolas, A., and Coleman, R.J. (Eds.), Ophiolite Genesis and the Evolution of the Oceanic Lithosphere: Dordrecht (Kluwer Acad. Publ), 458-500.

Dilek, Y., and Rowland, J.C., 1993. Evolution of a conjugate passive margin pair in the Mesozoic Antalya Complex, southern Turkey. Tectonics, 11:954-970.
Dreghorn, W., 1978. Landforms of the Girne Range, Northern Cyprus. Miner. Res. Explor. Inst. (MTA) of Turkey, 172.

Ducloz, C., 1972. The geology of the Bellapais-Kythrea area of the central Kyrenia Range, Cyprus. Cyprus Geol. Surv. Dept. Bull., 6:75.

Eaton, S., 1988. The sedimentology of Mid-Late Miocene carbonates and evaporites in southern Cyprus [Ph.D. thesis]. Univ. of Edinburgh.

Eaton, S., and Robertson, A.H.F., 1993. The Miocene Pakhna Formation, Cyprus, and its relationship to the Neogene tectonic evolution of the Eastern Mediterranean. Sediment. Geol., 86:273-296.

Emeis, K.-C., Robertson, A.H.F., Richter, C., et al., 1996. Proc. ODP, Init. Repts., 160: College Station, TX (Ocean Drilling Program).

Evans, G., Morgan, P., Evans, W.E., Evans, T.R., and Woodside, J. M., 1978. Faulting and halokinetics between Cyprus and Turkey. Geology, 6:392396.

Finetti, I., and Morelli, C., 1973. Geophysical exploration of the Mediterranean Sea. Bull. Geofis. Teor. Appl., 15:60.

Flecker, R.M., 1995. Miocene basin evolution of the Isparta angle, Southern Turkey [Ph.D. thesis]. Univ. of Edinburgh.

Flecker, R.M., Ellam, R.M., Robertson, A.H.F., Poisson, A., and Turner, J., 1997. Application of Sr isotope stratigraphy to the origin and evolution of the Isparta angle, southern Turkey. Terra Nova, 9, Abst. Suppl. 1:394.

Flecker, R.M., Robertson, A.H.F., Poisson, A., and Müller, C., 1995. Facies and tectonic significance of two contrasting Miocene basins in south coastal Turkey. Terra Res., 7:221-232.

Floyd, P.A., Kelling, G., Gökçen, S.L., and Gökçen, N., 1992. Arc-related origin of volcaniclastic sequences in the Misis Complex, Southern Turkey. J. Geol., 100:221-230.

Follows, E.J., 1990. Sedimentology and tectonic setting of Miocene reef and related sediments in Cyprus [Ph.D. thesis]. Univ. Edinburgh.

, 1992. Patterns of reef sedimentation and diagenesis in the Miocene of Cyprus. Sediment. Geol., 79:225-253.

Follows, E.J., and Robertson, A.H.F., 1990. Sedimentology and structural setting of Miocene reefal limestones in Cyprus. In Malpas, J., Moores, E.M., Panayiotou, A., and Xenophontos, C. (Eds.), Ophiolites: Oceanic Crustal Analogues: Nicosia, Cyprus (Geol. Surv. Dep., Minist. Agric. Nat. Resour.), 207-216.

Follows, E.J., Robertson, A.H.F., and Scoffin, T.P., 1996. Tectonic controls of Miocene reefs and related carbonate facies in Cyprus. In Fransee, E.K., Esteban, M., Ward, W.C., and Rouchy, J.-M. (Eds.), Models for Carbonate Stratigraphy from Miocene Reef Complexes of Mediterranean Regions. SFCM Concepts Sedimentol. Paleontol., 5:295-316.

Fourcade, E., Dercourt, J., Gunay, Y., Azema, J., Közlü, H., Bellier, J.P., Cordey, J.P., Cros, F., De Wever, P., Enay, P., Hernandez, R., Lauer, J., and Vrielynck, B., 1991. Stratigraphie et paléogéographie de la marge septentrionale de la platforme arabe au Mesozoique (Turquie de SudEast). Bull. Soc. Geol. Fr., 161:27-41.

Freund, R., Goldberg, M., Weissbrod, T., Druckman, Y., and Derin, B., 1975. The Triassic Jurassic structure of Israel and its relation to the origin of the eastern Mediterranean. Geol. Surv. Isr. Bull., 65:1-26.

Frizon de Lamotte, D., Poisson, A., Aubourg, C., and Temiz, H., 1995. Chevauchements post Tortoniens vers l'ouest puis vers le sud au coeur de l' Angle d'Isparta (Taurus, Turquie): consequences géodynamique. Bull. Soc. Geol. Fr., 166:527-538.

Fuchtbauer, H., and Richter, D.K., 1983. Carbonate internal breccias: a source of mass flows at early geosynclinal platform margins in Greece. Spec. Publ.-Soc. Econ. Paleontol. Mineral., 33:207-215.

Garfunkel, Z., 1987. Post-Precambrian sediments. In Bentor, Y.K., and Eyal, M. (Eds.), The Geology of Southern Sinai: its Implications for the Evolution of the Arabo-Nubian Massif (Vol. 1): Jebel Sabbagh Sheet, with geological map, 1:100,000, Jerusalem, Isr. Acad. Sci. Humanities, 368-392. , 1988. The pre-Quaternary geology of Israel. In Yom-Tov, Y., and Tchernov, E. (Eds.), The Zoogeography of Israel: Dordrecht (Junk Publ.). , 1989. Tectonic setting of Phanerozoic magmatism in Israel. Isr. $J$. Earth Sci., 38:51-74.

- 1992. Darfur-Levant aray of volcanics: a 140-Ma-long record of a hot spot beneath the African-Arabian continent, and its bearing on Africa's absolute motion. Isr. J. Earth Sci., 40:135-150.

Garfunkel, Z., and Derin, B., 1984. Permian-early Mesozoic tectonism and continental margin formation in Israel and its implications for the history of the Eastern Mediterranean. In Dixon, J.E., and Robertson, A.H.F. 
(Eds.), The Geological Evolution of the Eastern Mediterranean. Geol. Soc. Spec. Publ. London, 17:187-201.

Garrison, R.E., Schreiber, B.C., Bernoulli, D., Fabricius, F.H., Kidd, R.B., and Melières, F., 1978. Sedimentary petrology and structures of Messinian evaporitic sediments in the Mediterranean Sea, Leg 42A, Deep Sea Drilling Project. In Hsü, K.J., Montadert, L., et al., Init. Repts. DSDP, 42 (Pt. 1): Washington (U.S. Govt. Printing Office), 571-611.

Gass, I.G., 1990. Ophiolites and oceanic lithosphere. In Malpas, J., Moores, E.M., Panayiotou, A., and Xenophontos, C. (Eds.), Ophiolites Oceanic Crustal Analogues. Proc. Symp. "Troodos 1987," 1-12.

Gass, I.G., MacLeod, C.J., Murton, B.J., Panayiotou, A., Simonian, K.O., and Xenophontos, C., 1994. The Geology of the South Troodos Transform Fault Zone. Mem., Cyprus Geol. Surv. Dep., 9:218.

Gass, I.G., and Masson-Smith, D., 1963. The geology and gravity anomalies of the Troodos Massif, Cyprus. Philos. Trans. R. Soc. London A, 255:417-467.

Giermann, G., 1969. The Eastern Mediterranean Ridge. Rapp. Comm. Int. Mer Medit., 19:605-607.

Ginsman, A., Folkman, Y., Rybakov, M., Rotstein, Y., Assael, R., and Yuval, Z., 1993. Israel-Bouguer gravity map $(1: 500,000)$.

Ginsburg, A., and Gvirtzman, G., 1979. Changes across the crust and in the sedimentary cover across the transition from the Arabian platform to the Mediterranean basin: evidence from seismic refraction and sedimentary studies in Israel and in Sinai. Sediment. Geol., 23:19-36.

Girdler, R.W., 1986. The opening of the Red Sea. In Geology of the Real World: the Kingsley Dunham Volume. Inst. Mining Metall., London, 143-153.

Glennie, K.W., Hughes Clarke, M.W., Boef, M.W., Pilaar, M.G.H., and Reinhardt, B., 1990. Inter-relationship of the Makran-Oman Mountains belts of convergence. In Robertson, A.H.F., Searle, M.P., and Ries, A.C. (Eds.). The Geology and Tectonics of the Oman Region. Geol. Soc. Spec. Publ. London, 49:773-787.

Glover, C., 1996. Plio-Quaternary Sediments and Neotectonics of the Isparta Angle, south west Turkey [Ph.D. thesis]. Univ. Edinburgh.

Glover, C., and Robertson, A.H.F., 1993. Delta progradation and terrace formation related to regional uplift, Aksu basin, Southern Turkey. 7th Eur. Union Geosci., Strasburg, Terra Abstracts (1) of Terra Nova, 5:279.

1998. Role of extensional processes and uplift in the Plio-Quaternary sedimentary and tectonic evolution of the Aksu Basin, south west Turkey. J. Geol. Soc. London, 155:335-365.

Gökçen, N., Gökçen, S.L., and Kelling, G., 1991. Microfaunal biostratigraphy of Cenozoic sequences from the Misis-Andırın area, Southern Turkey. Sediment. Geol., 59:205-235.

Gökçen, S.L., Kelling, G., Gökçen, N., and Floyd, P.A., 1988. Sedimentology of a Late Cenozoic collisional sequence: the Misis Complex, Adana, Southern Turkey. Newsl. Stratigr., 24:111-135.

Gözuböl, A.M., and Gürpınar, O., 1980. The geology and the tectonic evolution of the north of Kahramanmaraș. 5th Petrol. Congr. Turkey, 21-29.

Gürbüz, K., 1993. Identification and evolution of Miocene submarine fans in the Adana Basin, Turkey [Ph.D. thesis]. Keele Univ., U.K.

Gürbüz, K., and Kelling, G., 1985. Provenance of Miocene submarine fans in the northern Adana Basin, southern Turkey: a test of discriminant function analysis. Geol. J., 28:277-293.

Gutnic, M., Monod, O., Poisson, A., and Dumont, J.-F., 1979. Géologie des Taurus occidentales (Turquie), Mem. Soc. Geol. Fr., 58:1-112.

Gvirtzman, G., 1990. Sediment accumulation rates and migration of shelf edge, continental slope and depocentres across the Tethyan margin of the Arabian platform in Israel during the Cretaceous. I.G.C.P. Cretaceous Field Conf., Israel. Progr. and Abstracts.

, 1993. Lower Cretaceous stratigraphy in Israel: updated correlation. Ann. Meeting Isr. Geol. Soc., March iss.:52-53.

Gvirtzman, G., Almogi-Labin, A., Honigstein, A., and Reiss, Z., 1989. Upper Cretaceous high-resolution multiple stratigraphy, northern margin of the Arabian platform, central Israel. Cretaceous Res., 10:107-135.

Gvirtzman, G., and Steinitz, G., 1982. The Asher volcanics: an Early Jurassic event in northern Israel. GSI, Curr. Res., 1982:28-34.

Hall, J.K., 1994. Bathymetric chart of the Mediterranean Sea. Geol. Surv. Isr.

Hall, R., 1976. Ophiolite emplacement and the evolution of the Taurus suture zone, South-east Turkey. Bull. Geol. Soc. Am., 87:1078-1088.

Harland, W.B., Cox, A.V., Llewellyn, P.G., Pickton, C.A.G., Smith, A.G., and Walters, R., 1982. A Geologic Time Scale: Cambridge (Cambridge Univ. Press).

Hayward, A.B., 1984. Miocene clastic sedimentation related to the emplacement of the Lycian Nappes and the Antalya Complex, south west Turkey.
In Dixon, J.E., and Robertson, A.H.F. (Eds), The Geological Evolution of the Eastern Mediterranean. Geol. Soc. Spec. Publ. London, 17:287-300.

Hayward, A.B., and Robertson, A.H.F., 1982. Direction of ophiolite emplacement inferred from Cretaceous and Tertiary sediments of an adjacent autochthon, the Bey Dağları, S.W. Turkey. Bull. Geol. Soc. Am., 93:68-75.

Helvaci, C., and Griffin, W.L., 1984. Rb-Sr geochronology of the Bitlis Massif, Avnik (Bingöl) area, S.E. Turkey. In Dixon, J.E., and Robertson, A.H.F. (Eds.), The Geological Evolution of the Eastern Mediterranean, 17:403-414.

Hempton, M.R., 1982. The North Anatolian fault and complexities of continental escape. J. Struct. Geol., 4:502-504.

1984. Results of detailed mapping near Lake Hazar (Eastern Taurus Mountains). In Tekeli, O., and Göncüoğlü, M.C. (Eds.), Geology of the Taurus belt: Ankara, Turkey (MTA Ankara), 223-228.

Hirsch, F., 1984. The Arabian sub-plate during the Mesozoic. In Dixon, J.E., and Robertson, A.H.F. (Eds.), Geological Evolution of the Eastern Mediterranean. Geol. Soc. Spec. Publ. London, 17:217-224.

Hirsch, F., Flexer, A., Rosenfeld, A., and Yellin-Dror, A., 1995. Palinspastic and crustal studies of the Eastern Mediterranean. J. Pet. Geol., 18:149170.

Houghton, S.D., Jenkins, D.G., Xenophontos, C., and Gass, I.G., 1990. Microfossil evidence for a latest Pliocene ages for Amathus and Khirokitia channel deposits, southern Cyprus, and thereby the unroofing of the Troodos Massif. In Malpas, J., Moores, E.M., Panayiotou, A., and Xenophontos, C. (Eds.), Ophiolites: Oceanic Crustal Analogues: Nicosia, Cyprus (Geol. Surv. Dep., Minist. Agric. Nat. Resour.), 231-234.

Hsü, K.J., 1990. Tectonic facies concept applied to interpret the geology of Cyprus. Rapp. Proc. Verb. Comm. Int. Expl. Mer Mediterr, 33:90.

Hsü, K.J., Montadert, L., et al., 1978. Init. Repts. DSDP, 42 (Pt. 1): Washington (U.S. Govt. Printing Office).

Hsü, K.J., Montadert, L., Bernoulli, D., Cita, M.B., Erickson, A., Garrison, R.E., Kidd, R.B., Melières, F., Müller, C., and Wright, R., 1978. History of the Mediterranean salinity crisis. In Hsü, K.J., Montadert, L., et al., Init. Repts. DSDP, 42 (Pt. 1): Washington (U.S. Govt. Printing Office), 1053-1078.

Ivanov, M.K., Limonov, M.K., and Woodside, J.M., 1992. Geological and geophysical investigations in the Mediterranean and Black Seas: initial results of the "Training through Research" Cruise of RV Gelendzhik in the Eastern Mediterranean and the Black Sea (June-July, 1991), UNESCO Rept. Mar. Sci., 1992.

Jackson, J.A., and McKenzie, D.M.P., 1984. Active tectonics of the AlpineHimalayas belt between western Turkey and Pakistan. Geophys. J. R. Astron. Soc., 77:185-264.

, 1989. The relationship between plate motions and seismic moment tensors, and rates of active deformation in the Mediterranean and middle east. Geophys. J. R. Astron. Soc., 93:45-73.

Juteau, T., 1970. Petrogenèse des ophiolites des Nappes d'Antalya (Taurus Lycien Oriental): leur liaison avec une phase d'expansion oceanique active au Trias superieur. Mem. Sci. Terre, 15:25-288.

Karig, D.E., and Közlü, H., 1990. Late Palaeogene evolution of the triple junction region near Maraș south-central Turkey. J. Geol. Soc. London, 147:1023-1034.

Kastens, K., 1981. Structural causes and sedimentological effects of the "Cobblestone Topography" in the Eastern Mediterranean [Ph.D. dissert.]. Scripps Inst. Oceanography, Univ. of California, San Diego, CA.

, 1991. Rate of outward growth of the Mediterranean Ridge accretionary complex. Tectonophysics, 199:25-50.

Kastens, K.A., Breen, N.A., and Cita, M.B., 1992. Progressive deformation on an evaporite-bearing accretionary complex: SeaMARC 1, SeaBeam, and piston-core observations from the Mediterranean Ridge. Mar. Geophys. Res., 14:249-298.

Kastens, K.A., Mascle, J., et al., 1990. Proc. ODP, Sci. Results, 107: College Station, TX (Ocean Drilling Program).

Kelling, G., Gökçen, S.L., Floyd, P.A., and Gökçen, N., 1987. Neogene tectonics and plate convergence in the Eastern Mediterranean: new data from southern Turkey. Geology, 15:425-429.

Kempler, D., 1994. Tectonic patterns in the Eastern Mediterranean [Ph.D. thesis]. Hebrew Univ., Jerusalem.

Kempler, D., and Ben-Avraham, Z., 1987. The tectonic evolution of the Cyprean Arc. Ann. Tecton., 1:58-71

Kempler, D., and Garfunkel, Z., 1991. The northeastern Mediterranean triple junction from a plate tectonic kinematic point of view. Bull. Tech. Univ. Istanbul, 44:425-454. 
1994. Structures and kinematics in the northeastern Mediterranean: a Study of an irregular plate boundary. Tectonophysics, 234:19-32.

Kissel, C., Averbuch, O., Frizon de Lamotte, D., Monod, O., and Allerton, S., 1990. First palaeomagnetic evidence of a post-Eocene clockwise rotation of the Western Tauruss thrust belt, east of the Isparta reentrant (Southwestern Turkey). Earth Planet. Sci. Lett., 117:1-14.

Kissel, C., and Laj, C., 1988. The Tertiary geodynamical evolution of the Aegean arc: a palaeomagnetic reconstruction. Tectonophysics, 146:183201.

Kissel, C., and Poisson, A., 1986. Étude paléomagnetique préliminaire des formations Neogène du bassin d'Antalya (Taurus occidentales-Turquie). C. R. Acad. Sci. Ser. 2, 302:711-716.

Kluyver, M., 1969. Report on a regional geological mapping in Paphos District. Bull. Geol. Surv. Cyprus, 4:21-36.

Kogan, L.F., and Stenin, A.M., 1994. Multichannel MOV-OCT (CDP) seismic profiling during Cruise 5 of R/V Akademik Nikolaj Strakhov (Preliminary results). In Krasheninnikov, V.A., and Hall, J.K. (Eds.), Geological Structure of the Northeastern Mediterranean: (Cruise 5 of the Research Vessel Akademik Nikolaj Strakhov: Jerusalem (Historical ProductionsHall Ltd.), 99-113.

Krasheninnikov, V.A., 1994. Stratigraphy of the Maastrichtian and Cenozoic deposits of the coastal part of northwestern Syria (Neoautochthon of the Bassit ophiolite massif). In Hall, J.K. (Ed.), Geological Structure of the Northeastern Mediterranean: (Cruise 5 of the Research Vessel Akademik Nokolaj Strakhov: Jerusalem (Historical Productions-Hall Ltd.), 265276.

Krasheninnikov, V.A., and Kaleda, K.G., 1994. Stratigraphy and lithology of the Upper Cretaceous and Cenozoic deposits of the key Perapedhi section (Southern Cyprus) by means of radiolarians and correlation with the foraminiferal zones. In Krasheninnikov, V.A., and Hall, J.K. (Eds.), Geological Structure of the Northeastern Mediterranean (Cruise 5 of the Research Vessel Akademik Nokolaj Strakhov): Jerusalem (Historical Productions-Hall Ltd.), 219-250.

Krasheninnikov, V.A., Udintsev, G.B., Mouraviov, V., and Hall, J.K., 1994. Geological structure of the Eratosthenes Seamount. In Krasheninnikov, V.A., and Hall, J.K. (Eds.), Geological Structure of the Northeastern Mediterranean (Cruise 5 of the Research Vessel Akademik Nokolaj Strakhov): Jerusalem (Historical Productions-Hall Ltd.), 113-130.

Lapierre, H., 1972. Les formations sédimentaires et éruptives des nappes de Mamonia et leurs rélations avec le massif de Troodos (Cypre) [Thèse Doctoral]. Univ. Nancy, France.

Laws, E., and Wilson, M., 1997. Tectonics and magmatism associated with Mesozoic passive continental margin development in the Middle East. $J$. Geol. Soc. London, 154:459-464.

Le Pichon, X., 1982. Land-locked oceanic basins and continental collision: the Eastern Mediterranean as a case example. In Hsü, K.J. (Ed.), Mountain Building Processes: New York (Academic), 201-211.

Le Pichon, X., and Angelier, J., 1979. The Hellenic arc and trench system: a key to the neotectonic evolution of the eastern Mediterranean area. Tectonophysics, 60:1-42.

Le Pichon, X., Augustithis, S.S., and Mascle, J., 1982. Geodynamics of the Hellenic Arc and Trench. Spec. Iss., Tectonophysics, 86.

Lewy, Z., 1989. Correlation of lithostratigraphic units in the Upper Judea Group (Late Cenomanian-Late Coniacian). Isr. J. Earth Sci., 38:37-43.

Limonov, A.F., Woodside, J.M., and Ivanov, M.K. (Eds.), 1994. Mud Volcanism in the Mediterranean and Black Seas and Shallow Structure of the Eratosthenes Seamount: Initial Results of the Geological and Geophysical Investigations During the Third "Training through-Research" Cruise of the R/N Gelendzhik, (June-July, 1993). UNESCO Rep. Mar. Sci., 64.

Lippard, S.J., Shelton, A.W., and Gass, I.G., 1986. The Ophiolite of Northern Oman. Geol. Soc. London Mem., 11.

Livermore, R.A., and Smith, A.G., 1984. Some boundary conditions for the evolution of the Mediterranean region. In Stanley, D.J., and Wezel, F.-C. (Eds.), Geological Evolution of the Mediterranean Basin: Berlin (Springer-Verlag), 83-100.

Lort, J. M., 1977. Geophysics of the Mediterranean Sea Basins. In Nairn, A.E.M., Kanes, W.H., and Stehli, F.G. (Eds.), The Ocean Basins and Margins (Vol. 4A): The Eastern Mediterranean: New York (Plenum), 151-313.

Lwtwyn, J.N., and Casey, J.F., 1995. The geochemistry of postkinematic mafic dike swarms and subophiolitic metabasites, Pozanti-Karsanti ophiolite, Turkey: evidence for ridge subduction. Geol. Soc. Am. Bull., 107:830-850
MacLeod, C.J., 1990. Role of the Southern Troodos Transform Fault in the rotation of the Cyprus microplate: evidence from the Eastern Limassol Forest Complex. In Malpas, J., Moores, E.M., Panayiotou, A., and Xenophontos, C. (Eds.), Ophiolites: Oceanic Crustal Analogues. Proc. Symp. "Troodos 1987," Geol. Surv. Dep. Cyprus, 75-86.

MacLeod, C.J., and Murton, B.J., 1993. Structure and tectonic evolution of the Southern Troodos Transform Fault Zone, Cyprus. In Prichard, H.M., Alabaster, T., Harris, N.B.W., and Neary, C.R. (Eds.), Magmatic Processes and Plate Tectonics. Geol. Soc. Spec. Publ. London, 76:141-176.

Makris, J., Ben-Avraham, Z., Behle, A., Ginzburg, A., Gieze, P., Steinmetz, L., Whitmarsh, R.B., and Eleftheriou, S., 1983. Seismic refraction profiles between Cyprus and Israel and their interpretation. Geophys. J. R. Astron. Soc., 75:575-591.

Makris, J., and Henke, C.H., 1992. Pull-apart evolution of the Red Sea. J. Pet. Geol., 15:127-134.

Makris, J., and Stobbe, C., 1984. Physical properties and state of the upper mantle of the Eastern Mediterranean deduced from geophysical data. In Morelli, C. (Ed.), Geological and Geodynamical Aspects of the Mediterranean. Mar. Geol., 55:347-363.

Malpas, J., Calon, T., and Squires, G., 1993. The development of a Late Cretaceous microplate suture zone in S.W. Cyprus. In Prichard, H.M., Alabaster, T., Harris, N.B.W., and Neary, C.R. (Eds.), Magmatic Processes and Plate Tectonics. Geol. Soc. Spec. Publ. London, 76:177-196.

Malpas, J., Xenophontos, C., and Williams, D., 1992. The Ayia Varvara Formation of SW Cyprus: a product of complex collisional tectonics. Tectonophysics, 212:193-211.

Mantis, M., 1970. Upper Cretaceous-Tertiary Foraminiferal Zones in Cyprus. Sci. Res. Cent. Cyprus, Epithris, 3:227-241.

Marcoux, J., 1974. Alpin type Triassic of the upper Antalya nappe (western Tauruss, Turkey). In Zapfe, H. (Ed.), Die Stratigraphie der Alpin-Mediterrannean Trias. Wien, 145-146.

1995. Initiation of the south-Neotethys margin in the Antalya nappes (SW Turkey): Late Permian and Early Mid-Triassic rifting events, late Mid Triassic oceanization. EUG, 175. (Abstract)

Marcoux, J., Ricou, L.-E., Burg, J.P., and Brun, J.P., 1989. Shear-sense criteria in the Antalya thrust system (south-western Turkey): evidence for southward emplacement. Tectonophysics, 161:81-91.

Mart, Y., 1984. The tectonic regime of the southeastern Mediterranean continental margin. In Morelli, C. (Ed.), Geological and Geodynamical Aspects of the Mediterranean. Mar. Geol., 55:365-386.

, 1987. Superpositional tectonic patterns along the continental margin of the southeastern Mediterranean: a review. Tectonophysics, 140:213-232.

1994. Ptolemais Basin: the tectonic origin of a Senonian marine basin underneath the southeastern Mediterranean Sea. Tectonophysics, 234:5-18.

Mart, Y., Robertson, A.H.F., and Woodside, J., 1997. Cretaceous tectonic setting of Eratosthenes Seamount in the eastern Mediterranean Neotethys: initial results of ODP Leg 160. C.R. Acad. Sci. Ser. 2a, 324:127-134.

Mascle, J., Le Cleach, H.A., and Jongsma, D., 1986. The Eastern Hellenic margin from Central Crete to Rhodes: examples of progressive collision. Mar.Geol., 73:145-168.

Mascle, J., Lohmann, G.P., Clift, P.D., et al., 1996. Proc. ODP, Init. Repts., 159: College Station, TX (Ocean Drilling Program).

McCallum, J.E., 1989. Sedimentation and tectonics of the Plio-Pleistocene of Cyprus [Ph.D. thesis]. Univ. of Edinburgh

McCallum, J.E., and Robertson, A.H.F., 1990. Pulsed uplift of the Troodos Massif: evidence from the Plio-Pleistocene Mesaoria Basin. In Malpas, J., Moores, E.M., Panayiotou, A., and Xenophontos, C. (Eds.), Ophiolites: Oceanic Crustal Analogues. Proc. Symp. "Troodos 1987”: Nicosia, Cyprus (Geol. Surv. Dep., Minist. Agric. Nat. Resour.), 217-229.

1995. Sedimentology of two fan-delta systems in the PliocenePleistocene of the Mesaoria Basin, Cyprus. Sediment. Geol., 98:215-244.

McCallum, J.E., Scrutton, R.A., Robertson, A.H.F., and Ferrari, W., 1993. Seismostratigraphy and Neogene-Recent depositional history of the south central continental margin of Cyprus. Mar. Pet. Geol., 10:426-425.

McKenzie, D.P., 1978. Active tectonism in the Alpine-Himalayan belt: the Aegean Sea and the surrounding regions (tectonics of the Aegean region). Geophys. J.R. Astron. Soc., 55:217-254.

Michard, A., Whitechurch, H., Ricou, L.E., Montigny, R., and Yazgan, E., 1984. Tauric subduction (Malatya-Elaziğ provinces) and its bearing on tectonics of the Tethyan Realm in Turkey. In Dixon, J.E., and Robertson, A.H.F. (Eds.), The Geological Evolution of the Eastern Mediterranean. Geol. Soc. Spec. Publ. London, 17:349-360. 
Monod, O., 1977. Récherches géologique dans les Taurus occidental au sud de Beyșehir (Turquie) [Thèse de Doct. Sci.]. Univ. Paris-Sud, Orsay.

Montadert, L., Letouzey, J., and Mauffret, A., 1978. Messinian event: seismic evidence. In Hsü, K.J., Montadert, L., et al., Init. Repts. DSDP, 42 (Pt. 1): Washington (U.S. Govt. Printing Office), 1037-1050.

Moores, E.M., Robinson, P.T., Malpas, J., and Xenophontos, C., 1984. Model for the origin of the Troodos massif, Cyprus, and other Mideast ophiolites. Geology, 12:223-226.

Moores, E.M., and Vine, F.J., 1971. The Troodos Massif, Cyprus and other ophiolites as oceanic crust: evaluation and implications. Philos. Trans. $R$. Soc. London A, 268:443-466.

Morel, S.W., 1960. The Geology and Mineral Resources of the ApsiouAkrotiri Area. Mem., Cyprus Geol. Surv. Dep., 7:52-88.

Morris, A., 1996. A review of palaeomagnetic research in the Troodos ophiolite, Cyprus. In Morris, A., and Tarling, D.H. (Eds.), Palaeomagnetism and Tectonics of the Mediterranean Region. Geol. Soc. Spec. Publ. London, 105:311-324.

Morris, A., Creer, K.M., and Robertson, A.H.F., 1990. Palaeomagnetic evidence for clockwise rotations related to dextral shear along the southern Troodos transform fault, Cyprus. Earth Planet. Sci. Lett., 99:250-262.

Morris, A., and Robertson, A.H.F., 1993. Miocene remagnetism of carbonate platform and Antalya Complex units within the Isparta Angle, south west Turkey, I. Tectonophysics, 220:243-266.

Mukasa, S.B., and Ludden, J.N., 1987. Uranium-lead ages of plagiogranites from the Troodos ophiolite, Cyprus, and their tectonic significance. Geology, 1:82-828.

Murton, B.J., 1990. Was the Southern Troodos Transform Fault a victim of microplate rotation? In Malpas, J., Moores, E.M., Panayiotou, A., and Xenophontos, C. (Eds.), Ophiolites: Oceanic Crustal Analogues. Proc. Symp. "Troodos 1987," Geol. Surv. Dep., Cyprus, 87-98.

Murton, B.J., and Gass, I.G., 1986. Western Limassol Forest Complex, Cyprus: part of an Upper Cretaceous leaky transform fault. Geology, 14:255-258.

Nur, A., and Ben-Avraham, Z., 1978. The Eastern Mediterranean and Levant: tectonics of continental collision. Tectonophysics, 46:297-311.

Okay, A.I., 1990. The origins of the allochthons in the Lycian belt, southwestern Turkey. Tectonophysics, 177:367-379.

Okay, A.I., and Özgül, N., 1984. HP/LT metamorphims and the structure of the Alanya Massif. In Dixon, J.E., and Robertson, A.H.F. (Eds.), The Geological Evolution of the Eastern Mediterranean. Geol. Soc. Spec. Publ. London, 17:429-440.

Oral, M.B., Reilinger, R., Töksoz, M.N., King, R.W., Barka, A.A., and Lenk, O., 1994. GPS measurements of crustal deformation in Turkey (19881992): coherent rotation of the Anatolian Plate. Am. Geophys. Union, 116. (Abstract)

Orszag-Sperber, F., Rouchy, J.-M., and Elion, P., 1989. The sedimentary expression of regional tectonic events during the Miocene Pliocene transition in the southern Cyprus basins. Geol. Mag., 126:291-299.

Özgül, N., 1984. Stratigraphy and tectonic evolution of the central Taurus. In Tekeli, O., and Göncüoğlü, M.C. (Eds.), Geology of the Taurus Belt: Ankara, Turkey (MTA Ankara), 77-90.

Parlak, O., Delaloye, M., and Bingöl, E., 1995. Origin of sub-ophiolitic metamorphic rocks beneath the Mersin ophiolite, Southern Turkey. Ofioliti, 20:97-110.

Parrot, J.-F., 1977. Assemblage ophiolitique de Baer-Bassit et termes éffusives du volcano-sedimentaire. Trav. Doc. L'ORSTROM, 72.

Payne, A.S., 1995. Neogene tectonic and sedimentary evolution of the Polis graben system, West Cyprus [Ph. D. thesis]. Univ. Edinburgh.

Payne, A.S., and Robertson, A.H.F., 1996. Neogene supra-subduction zone extension in the Polis graben system, West Cyprus. J. Geol. Soc. London, 153:613-628

Pearce, J.A., Bender, J.F., De Long, S.E., Kidd, W.S.F., Low, P.J., Guner, Y., Saröğlü, F., Yilmaz, Y., Moorbath, S., and Mitchell, J.G., 1990. Genesis of collisional volcanism in eastern Anatolia, Turkey. J. Volcanol. Geotherm. Res.,44:189-229.

Pearce, J.A., Lippard, S.J., and Roberts, S., 1984. Characteristics and tectonic significance of supra-subduction zone ophiolites. In Kokelaar, B.P., and Howells, M.F. (Eds.), Marginal Basin Geology. Geol. Soc. Spec. Publ. London, 16:74-94.

Perincek, D., 1979. The geology of Hazro-Korudağ-Cüngüs-Maden-ErganiHazar-Elaziğ-Malatza area. Spec. Publ. Geol. Soc. Turkey.

Perincek, D., and Ozkaya, I., 1981. Tectonic evolution of the northern margin of Arabian plate. Bull. Inst. Earth Sci. Hacettepe Univ., 8:91-101. (in Turkish)
Pişkin, O., Delaloye, M., and Wagner, J.-J., 1986. Guide to the Hatay geology. Ofioliti, 11:87-104.

Poisson, A., 1977. Récherches géologiques dans les Taurides occidentales (Turquie) [Ph.D. thesis]. Univ. Paris-Sud, Orsay.

1984. The extension of the Ionian trough into southwestern Turkey. In Dixon, J.E., and Robertson, A.H.F. (Eds.), Geological Evolution of the Eastern Mediterranean. Geol. Soc. Spec. Publ. London, 17:241250.

Poole, A.J., 1992. Sedimentology, neotectonics and geomorphology related to tectonic uplift and sea-level change: Quaternary of Cyprus [Ph.D. thesis]. Univ. Edinburgh.

Poole, A.J., and Robertson, A.H.F., 1992. Quaternary uplift and sea-level change at an active plate boundary, Cyprus. J. Geol. Soc. London, 148:909-921.

Poole, A., Robertson, A.H.F., and Shimmield, G., 1990. Late Quaternary uplift of the Troodos ophiolite, Cyprus: uranium-series dating of Pleistocene coral. Geology, 18:894-897.

Price, S.P., and Scott, B., 1994. Fault-block rotations at the edge of a zone of continental extension: southwestern Turkey. J. Struct. Geol., 16:381-392.

Reed, T.J., 1993. The sedimentology of the Oligocene-Miocene transition in the Limassol-Larnaca area, southern Cyprus [M.Sci. thesis]. Univ. London Birkbeck Coll.

Reilinger, R., McClusky, S., Oral, M.B., King, R.W., and Toksöz, M.N., 1997. Global Positioning System measurements in the Arabia-AfricaEurasia plate collision zone. J. Geophys. Res., 102:9983-9999.

Reuber, I., 1984. Mylonatic ductile shear zones within tectonites and cumulates as evidence for an oceanic transform fault in the Antalya ophiolite, SW Turkey. In Dixon, J.E., and Robertson, A.H.F. (Eds.), The Geological Evolution of the Eastern Mediterranean. Geol. Soc. Spec. Publ. London, 17:319-334.

Ricou, L.-E., Marcoux, J., and Whitechurch, H., 1984. The Mesozoic organisation of the Tauruss: one or several oceanic basins. In Dixon, J.E., and Robertson, A.H.F. (Eds.), The Geological Evolution of the Eastern Mediterranean. Geol. Soc. Spec. Publ. London, 17:349-360.

Rigo de Righi, M., and Cortesini, A., 1964. Gravity tectonics in foothills structure belt of SE Turkey. AAPG Bull., 48:1911-1937.

Robertson, A.H.F., 1976. Pelagic chalks and calciturbidites from the lower Tertiary of the Troodos Massif, Cyprus. J. Sediment. Petrol., 46:1000710016.

, 1977a. The Kannaviou Formation, Cyprus: volcaniclastic sedimentation of a probable Late Cretaceous volcanic arc. J. Geol. Soc. London, 134:269-292.

, 1977b. The Moni Melange, Cyprus: an olistostrome formed at a destructive plate margin. J. Geol. Soc. London, 133:447-466.

, 1977c. Tertiary uplift history of the Troodos Massif, Cyprus. Geol. Soc. Am. Bull., 88:1763-1772.

1977. The origin and diagenesis of cherts from Cyprus. Sedimentology, 24:11-30.

1986. The Hatay ophiolite (southern Turkey) in its Eastern Mediterranean tectonic context: a report on some aspects of the field excursion. Ofioliti, 11:105-119.

1987. The transition of a passive margin to an Upper Cretaceous foreland basin related to ophiolite emplacement in the Oman Mountains. Geol. Soc. Am. Bull., 99:633-653.

, 1990. Tectonic evolution of Cyprus. In Malpas, J., Moores, E.M., Panayiotou, A., and Xenophontos, C. (Eds.), Ophiolites: Oceanic Crustal Analogues. Proc. Symp. "Troodos 1987," Nicosia, Cyprus (Geol. Surv. Dep., Minist. Agric. Nat. Resour.), 235-250.

, 1993. Mesozoic-Tertiary sedimentary and tectonic evolution of Neotethyan carbonate platforms, margins and small ocean basins in the Antalya Complex, Southwest Turkey. In Frostick, L.E., and Steel, R. (Eds.), Tectonic Controls and Signatures in Sedimentary Successions. Spec. Publ. Int. Assoc. Sedimentol., 20:415-465.

, 1994. Role of the tectonic facies concept in orogenic analysis and its application to Tethys in the Eastern Mediterranean region. Earth-Sci. Rev., 37:139-213.

Robertson, A.H.F., Clift, P.D., Degnan, P., and Jones, G., 1991a. Palaeogeographic and palaeotectonic evolution of the Eastern Mediterranean Neotethys. Palaeogeogr., Palaeoclimatol., Palaeoecol., 87:289-344.

Robertson, A.H.F., and Dixon, J.E., 1984. Introduction. In Dixon, J.E., and Robertson, A.H.F. (Eds.), The Geological Evolution of the Eastern Mediterranean. Geol. Soc. Spec. Publ. London, 17:1-74.

Robertson, A.H.F., Dixon, J.E., Brown, S., Collins, A., Morris, A., Pickett, E., Sharp, I., and Üstaömer, T., 1996a. Alternative tectonic models for the Late Paleozoic-Early Tertiary development of Tethys in the Eastern Med- 
iterranean region. In Morris, A., and Tarling, D.H. (Eds.), Paleomagnetism and Tectonics of the Mediterranean Region. Geol. Soc. Spec. Publ. London, 105:239-263.

Robertson, A.H.F., Eaton, S., Follows, E.J., and McCallum, J.E., 1991b. The role of local tectonics versus global sea-level change in the Neogene evolution of the Cyprus active margin. In Macdonald, D.I.M. (Ed.), Sedimentation, Tectonics and Eustacy Sea-level Changes at Active Margins. Spec. Publ. Int. Assoc. Sedimentol., 12:331-369.

Robertson, A.H.F., Eaton, S.E., Follows, E.J., and Payne, A.S., 1995a. Sedimentology and depositional processes of Miocene evaporites from Cyprus. Terra Nova, 7:233-254.

Robertson, A.H.F., Emeis, K.-C., Richter, C., Blanc-Valleron, M.-M., Bouloubassi, I., Brumsack, H.-J., Cramp, A., De Lange, G.J., Di Stefano, E., Flecker, R., Frankel, E., Howell, M.W., Janecek, T.R., Jurado-Rodriguez, M.-J., Kemp, A.E.S., Koizumi, I., Kopf, A., Major, C.O., Mart, Y., Pribnow, D.F.C., Rabaute, A., Roberts, A.P., Rullkötter, J.H., Sakamoto, T., Spezzaferri, S., Staerker, T.S., Stoner, J.S., Whiting, B.M., and Woodside, J.M., 1995b. Evidence of collisional processes associated with ophiolite obduction in the eastern Mediterranean: results from Ocean Drilling Program Leg 160. GSA Today, 5:213-221.

Robertson, A.H.F., and Grasso, M., 1995. Overview of the Late TertiaryRecent tectonic and palaeo-environmental development of the Mediterranean region. Terra Nova, 7:114-127.

Robertson, A.H.F., and Hudson, J.D., 1974. Pelagic sediments in the Cretaceous and Tertiary history of the Troodos Massif, Cyprus. In Hsü, K.J., and Jenkyns, H.C. (Eds.), Pelagic Sediments: On Land and Under the Sea. Spec. Publ. Int. Assoc. Sedimentol., 1:403-436.

Robertson, A.H.F., Kidd, R.B., Ivanov, M.K., Limonov, A.F., Woodside, J.M., Galindo-Zaldivar, J., and Nieto, L., 1994. Probing continental collision in the Mediterranean Sea. Eos, 75:233

- 1995c. Eratosthenes Seamount, easternmost Mediterranean: evidence of active collapse and underthrusting beneath the Cyprus active margin. Terra Nova, 7:254-264.

Robertson, A.H.F., and Waldron, J.W.F., 1990. Geochemistry and tectonic setting of Late Triassic and Late Jurassic-Early Cretaceous basaltic extrusives from the Antalya Complex, south west Turkey. In Savaşçin, M.Y., and Eronat, A.H (Eds.), International Earth Sciences Congress on Aegean Regions, 1990, Proc., 2:279-299.

Robertson, A.H.F., and Woodcock, N.H., 1979. The Mamonia Complex, south west Cyprus: the evolution and emplacement of a Mesozoic continental margin. Geol. Soc. Am. Bull., 90:651-665.

, 1980. Tectonic setting of the Troodos massif in the East Mediterranean. In Malpas, J., Moores, E.M., Panayiotou, A., and Xenophontos, C. (Eds.), Ophiolites: Oceanic Crustal Analogues. Proc. Symp. "Troodos 1987," Nicosia, Cyprus (Geol. Surv. Dep., Minist. Agric. Nat. Resour.), 36-49.

- 1982. Sedimentary history of the south-western segment of the Mesozoic-Tertiary Antalya continental margin, south-western Turkey. Eclog. Geol. Helv., 75:517-562.

, 1984. The SW segment of the Antalya Complex, Turkey as a Mesozoic-Tertiary Tethyan continental margin. In Dixon, J.E., and Robertson, A.H.F. (Eds.), The Geological Evolution of the Eastern Mediterranean. Spec. Publ. Geol. Soc. London, 17:251-272.

, 1986. The geological evolution of the Kyrenia Range: a critical lineament in the Eastern Mediterranean. In Reading, H.G., Watterson, J., and White, S.H. (Eds.), Major Crustal Lineaments and their Influence on the Geological History of the Continental Lithosphere. Proc. R. Soc. London discussion meeting, A317:141-178.

Robertson, A.H.F., and Xenophontos, C., 1993. Development of concepts concerning the Troodos ophiolite and adjacent units in Cyprus. In Prichard, H.M., Alabaster, T., Harris, N.B. and Neary, C.R. (Eds), Magmatic Processes and Plate Tectonics. Geol. Soc. Spec. Publ. London, 70:85120

Robinson, P.T., and Malpas, J., 1990. The Troodos Ophiolite of Cyprus: new perspectives on its origin and emplacement. In Malpas, J., Moores, E.M., Panayiotou, A., and Xenophontos, C. (Eds.), Ophiolites: Oceanic Crustal Analogues. Geol. Surv. Dep., Cyprus, 13-36.

Ron, H., Nur, A., and Hofstetter, A., 1990. Late Cenozoic and Recent strike slip tectonics in Mt. Carmel, Northern Israel. Ann. Tecton., 4:70-80.

Rotstein, Y., and Ben-Avraham, Z., 1985. Accretionary processes at subduction zones in the Eastern Mediterranean. Tectonophysics, 112:551-561.

Rotstein, Y., and Kafka, A.L., 1982. Seismotectonics of the Cyprean Arc, Eastern Mediterranean Region: subduction, collision and arc jumping. $J$. Geophys. Res., 87:7694-7707.
Ryan, W.B.F., Hsü, K.J., et al., 1973. Init. Repts. DSDP, 13 (Pts. 1 and 2): Washington (U.S. Govt. Printing Office)

Rybakov, M., Goldshmidt, V., Folkman, Y., Rotstein, Y., Ben-Avraham, Z., and Hall, J., 1994. Israel-magnetic anomaly map (1:500,000).

Savostin, L.A., Sibuet, J.C., Zonenshain, L.P., Le Pichon, X., and Rolet, J., 1986. Kinematic evolution of the Tethys belt, from the Atlantic to the Pamirs since the Triassic. Tectonophysics, 123:1-35.

Schiettecatte, J.P., 1971. Geology of the Misis Mountains. In Campbell, M. (Ed.), Geology and History of Turkey. Pet. Expl. Soc. Libya, Ann. Field Conf., 13:305-312.

Scrutton, R.A., 1982. Crustal structure and development of sheared passive margins. In Scrutton, R.A. (Ed.), Dynamics of Passive Margins. Am. Geophys. Union, Geodyn. Ser., 6:133-140.

Searle, M.P., and Graham, G.M., 1982. "Oman Exotics": Oceanic carbonate build-ups associated with the early stages of continental rifting. Geology, 10:43-49.

Searle, M.P., and Malpas, J., 1980. The structure and metamorphism of subophiolitic metamorphic rocks in the Oman Mountains. J. Geol. Soc. London, 139:235-248.

Searle, M.P., Windley, B.F., Coward, M.P., Cooper, D.W.J., Rex, A.J., Li Tingdong, D.C., Xuchang, X., Jan, M.Q., and Kumar, S., 1987. The closing of Tethys and the tectonics of the Himalayas. Geol. Soc. Am. Bull., 98:678-701.

Şengör, A.M.C., 1984. The Cimmeride orogenic system and the tectonics of Eurasia. Spec. Pap. Geol. Soc. Am., 195.

Şengör, A.M.C., Görür, N., and Saröğlü, F., 1985. Strike-slip faulting and related basin formation in zones of tectonic escape: Turkey as a case study. In Biddle, K.T., and Christie-Blick, N. (Eds.), Strike-slip Deformation, Basin Formation and Sedimentation. Soc. Econ. Paleont. Mineral., Spec. Publ., 37:227-264.

Şengör, A.M.C., and Yilmaz, Y., 1981. Tethyan plate tectonic evolution of Turkey: a plate tectonic approach. Tectonophysics, 75:181-241.

Şengör, A. M.C., Yilmaz, Y., and Süngürlü, O., 1984. Tectonics of the Mediterranean Cimmerides: nature and evolution of the western termination of Palaeo-Tethys. In Dixon, J.E. and Robertson, A.H.F. (Eds.), The Geological Evolution of the Eastern Mediterranean. Geol. Soc. Spec. Publ. London, 17:77-112.

Simonian, K.O., and Gass, I.G., 1978. Arakapas fault belt, Cyprus: a fossil transform fault. Geol. Soc. Am. Bull., 89:1220-1230.

Smith, A.C., 1971. Alpine deformation and the oceanic areas of Tethys, Mediterranean and Atlantic. Geol. Soc. Am. Bull., 82:2039-2070.

Smith, D.E., Kolenkiewicz, R., Robbins, J.W., Dunn, P.J., and Torrence, M.H., 1994. Horizontal crustal motion in the Central and Eastern Mediterranean inferred from satellite laser ranging measurements. Geophys. Res. Lett., 21:1979-1982.

Sonnenfeld, P., and Finetti, I., 1985. Messinian evaporites in the Mediterranean: a model of continuous inflow and outflow. In Stanley, D.J., and Wezel, F.-C. (Eds.), Geological Evolution of the Mediterranean Basin: New York (Springer-Verlag), 347-353.

Spray, J.G., and Roddick, J.C., 1981. Evidence for Upper Cretaceous transform metamorphism in West Cyprus. Earth Planet. Sci. Lett., 55:273291.

Stampfli, G., Marcoux, J., and Baud, A., 1991. Tethyan margins in space and time. Palaeogeogr., Palaeoclimatol., Palaeoecol., 87:373-410.

Swarbrick, R.E., 1980. The Mamonia Complex of S.W. Cyprus: a Mesozoic continental margin and its relationship with the Troodos Complex. In Panayiotou, A. (Ed.), Ophiolites. Proc. Int. Ophiolite Symp., Nicosia, 1979:86-92.

, 1993. Sinistral strike-slip and transpressional tectonics in an ancient oceanic setting: Mamonia Complex. J. Geol. Soc. London, 150:381-392.

Swarbrick, R.E., and Naylor, M.A., 1980. The Kathikas Melange, southwest Cyprus: late Cretaceous submarine debris flows. Sedimentology, 27:6378.

Swarbrick, R.E., and Robertson, A.H.F., 1980. Revised stratigraphy of the Mesozoic rocks of southern Cyprus. Geol. Mag., 117:547-563.

Toksöz, M.N., Reilinger, R., King, R., McClusky, B., Souter, B., and Oral, B., 1995. 1994 GPS measurements in Turkey and surrounding areas of the E. Mediterranean/Middle east. AGU Fall Meeting, 1995. (Abstract)

Udintsev, G.B., Zverev, A.S., Odinokov, Y., Efremov, V.N., Eleftheriou, S., and Hall, J.K., 1994. Structure of the post-Messinian sedimentary cover in the eastern part of the Mediterranean Sea. In Krasheninnikov, V.A., and Hall, J.K. (Eds.), Geological Structure of the Northeastern Mediterranean: Cruise 5 of the Research Vessel Akademik Nikolaj Strakhov: Jerusalem (Historical Productions-Hall Ltd.), 33-74. 
Underhill, J.R., 1989. Late Cenozoic deformation of the Hellenide foreland, western Greece. Geol. Soc. Am. Bull., 101:613-634.

Urquart, E., and Banner, F.T., 1994. Biostratigraphy of the supra-ophiolite sediments of the Troodos Massif, Cyprus: the Perapedhi, Kannaviou and Kathikas Formations. Geol. Mag., 131:499-518.

Waldron, J.W.F., 1984. Evolution of carbonate platforms on a margin of the Neotethys ocean: Isparta angle, south-western Turkey. Eclogae Geol. Helv., 77:553-581.

Watts, K.W., and Garrison, R.E., 1979. Sumeini Group, Oman-evolution of a Mesozoic carbonate slope on a South Tethyan continental margin. Sediment. Geol., 48:107-168.

Weaver, S.D., Saunders, A.D., Pankhurst, R.J., and Tarney, J., 1977. A geochemical study of magmatism associated with the initial stages of back-arc spreading. The Quaternary rocks of Bransfield Strait, South Shetland Islands. Contrib. Mineral. Petrol., 68:151-169.

Weiler, Y., 1965. The folded Kithrea flysch in Cyprus [Ph.D. thesis]. Univ. Jerusalem.

Weissbrod, T., 1987. The Late Palaeozoic geoanticlines in the Near East and North Africa. 11th Congr. Int. Statigr. Geol. Caronifère, Beijing. Compte Rendu, 4:334-343.

Westaway, R., and Arger, J., 1996. The Gülbası basin, southeastern Turkey: a complex discontinuity in a major strike-slip fault zone. J. Geol. Soc. London, 153:729-744.

Whitechurch, H., Juteau, T., and Montigny, R., 1984. Role of the Eastern Mediterranean ophiolites (Turkey, Syria, Cyprus) in the history of the Neo-Tethys. In Dixon, J.E., and Robertson, A.H.F. (Eds.), The Geological Evolution of the Eastern Mediterranean. Geol. Soc. Spec. Publ. London, 17:301-318.

Williams, G.D., Unlügenç, U.C., Kelling, G., and Demirkol, C., 1995. Tectonic controls on stratigraphical evolution of the Adana Basin, Turkey. $J$. Geol. Soc. London, 152:873-882.

Woodside, J.M., 1977. Tectonic elements and crust of the eastern Mediterranean Sea. Mar. Geophys. Res., 3:317-354.

, 1992. Area no 2 (Anaximander Mountains). In Initial results of the "Training through Research" cruise of RV Gelendzhik in the Eastern Mediterranean and the Black Sea (June-July, 1991). UNESCO, 1992:116-170.

Woodcock, N.H., and Robertson, A.H.F., 1977. Origins of some ophioliterelated rocks of the "Tethyan" belt. Geology, 5:373-376.

, 1982. Wrench and thrust tectonics along a Mesozoic-Cenozoic continental margin: Antalya Complex, S.W. Turkey. J. Geol. Soc. London, 139:147-163.
Woodside, J.M., and Dumont, J.F., 1997. The Anaximander Mountains are a southward rifted and foundered part of the southwestern Turkish Tauruss. Terra Nova (Suppl.), 9:394. (Abstract)

Yalçin, M.N., and Görür, N., 1984. Sedimentological evolution of the Adana basin. In Tekelı, O., and Güncüoğlü, M.C. (Eds.), Geology of the Tuaris Belt. Proc., 165-172.

Yazgan, E., 1984. Geodynamic evolution of the Eastern Taurus region. In Tekelı, O., and Güncüoğlü, M.C. (Eds.), Geology of the Taurus Belt: Ankara, Turkey (MTA Ankara), 199-208.

Yazgan, E., and Chessex, R., 1991. Geology and tectonic evolution of the Southeastern Taurides in the region of Malatya. Turkish Assoc. Pet. Geol. Bull., 3:1-42.

Yetiș, C., 1978. Geology of the Camardı (Niğde) region and the characteristics of the Ecemiş Fault Zone between Maden Boğazı and Kamişl1. Istanbul Univ. Rev. Fac. Sci. B, 43:41-4.

1984. New observations on the age of the Ecemiș Fault. In Tekeli, O., and Güncüoğlü, M.C. (Eds.), Geology of the Taurus Belt: Ankara, Turkey (MTA Ankara), 159-164.

Yetiş, C., Kelling, G., Gökçen, S.L., and Baroz, F., 1995. A revised stratigraphical framework for Later Cenozoic sequences in the northeastern Mediterranean region. Geol. Rundsch, 84:794-812.

Yilmaz, P.O., 1984. Fossil and K-Ar data for the age if the Antalya Complex, south west Turkey. In Dixon, J.E., and Robertson, A.H.F. (Eds.), The Geological Evolution of the Eastern Mediterranean. Geol. Soc. Spec. Publ. London, 17:335-348.

Yilmaz, Y., 1991. Allochthonous terranes in the Tethyan Middle East: Anatolia and the surrounding regions. In Dewey, J.F., Gass, I.G., Curry, G.B., Harris, N.B.W., and Şengör, A.M.C. (Eds.), Allochthonous Terranes: Cambridge (Cambridge Univ. Press), 155-168.

- 1993. New evidence and model on the evolution of the southeast Anatolian orogen. Geol. Soc. Am. Bull., 105:251-271.

Date of initial receipt: 13 Nay 1997

Date of acceptance: 17 November 1997 Ms 160SR-061 